\title{
Biophysical Land Classification, Range Assess
Significant Features Assessment \\ of the \\ Hand Hills Ecological Reserve
}
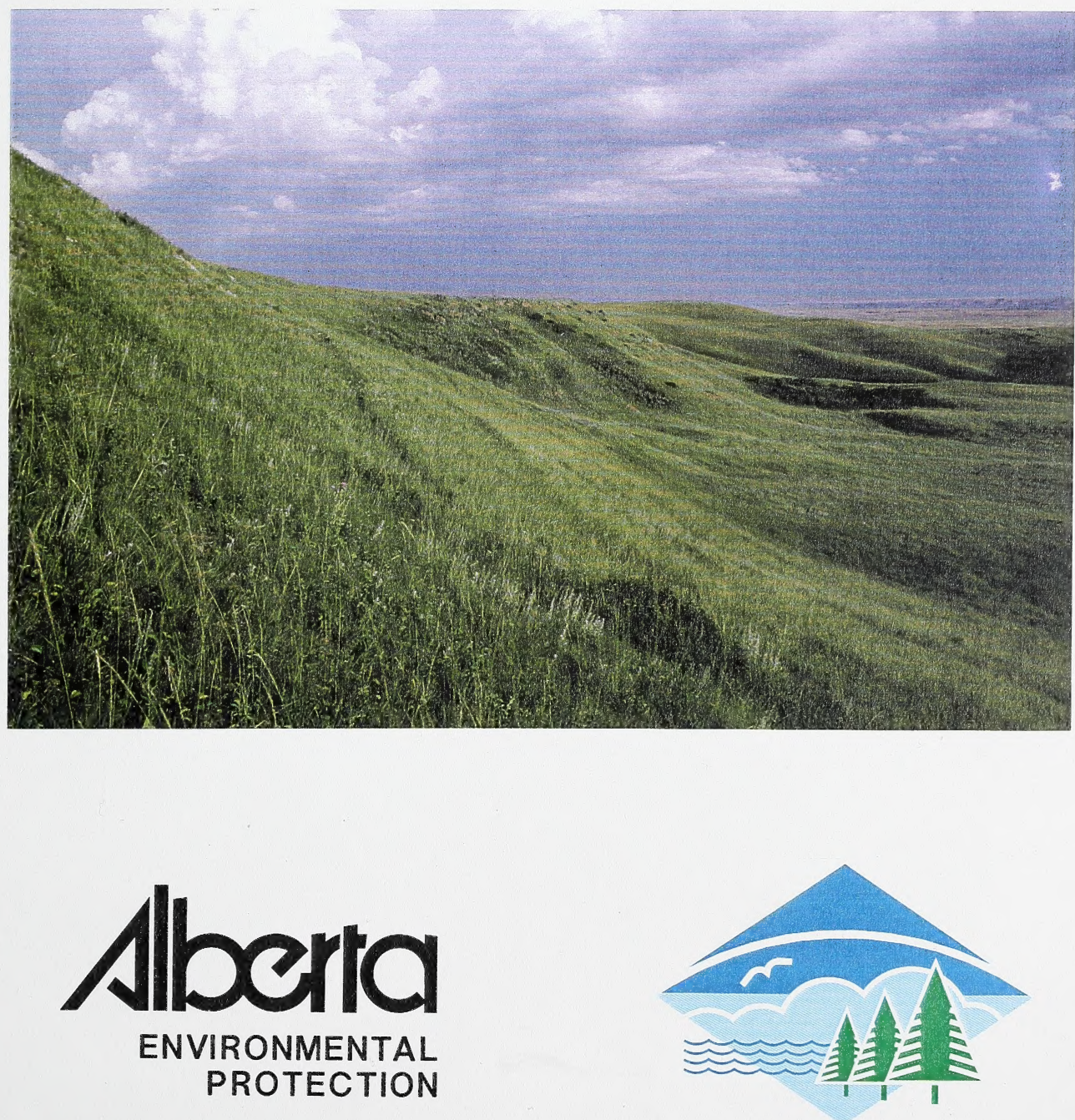
Digitized by the Internet Archive in 2017 with funding from University of Alberta Libraries 
Biophysical Land Classification, Range Assessment and

Significant Features Assessment

of the

\section{Hand Hills Ecological Reserve}

Prepared by

Andre M. Legris

Beth Cornish

Resource Data Division

Alberta Environmental Protection

Edmonton, Alberta

March, 1997 



\section{Executive Summary}

The Hand Hills Ecological Reserve contains the largest remaining tract of relatively undisturbed Northern Fescue Grassland in the world.

As such it is a unique part of the Canadian landscape. In order to protect and manage this rare grassland effectively, a detailed biophysical study was done of the Reserve in 1996. This study catalogued the ecological and physical resources of the Reserve, while also examining the human impacts on this ecosystem.

The Reserve is located on the top of the Hand Hills, which is a remnant tertiary plateau, one of only three such areas in the Alberta prairie. The landscape of the Reserve is characterized by a dramatic escarpment along its west side, a set of rolling highlands along the south end, and three large coulees which dissect the central and western portions. The northern and eastern areas consist of a slightly rolling plain.

Surficial deposits include ground moraine, glaciofluvial veneers, glaciolacustrine blankets, and several interesting landforms such as sand hills, drumlins, and remnant beach ridges.

The soils of the Reserve are dominated by Dark Brown and Black Chernozems, interspersed with areas of Solonetzic and Solod soils. Localized areas of Gleysols are present in depressional areas, with Regosols along the coulees.

The vegetation is dominated by Rough Fescue grasslands and, to a lesser extent, Rough Fescue Western Porcupine grasslands. There are twenty-two different natural vegetation types: eight grasslands, five shrub communities, three woodlands, two ephemeral riparian meadows, and four wetlands. In addition, there are four community types which have resulted from the direct effects of human disturbances.

Most of the Rough Fescue grasslands are in good condition, mainly because they occur in areas which are either restricted to haying, or are seldom used by cattle. In areas where cattle are present, various grasslands types have moved in, each containing species indicative of moderate to heavy grazing pressure. Areas without cattle are characterized by lush grasslands and, in moist places, spectacular flower blooms.

The range over most of the Reserve is categorized as either excellent or good. Areas with fair to poor range are those where invader species, such as Awnless Brome, are present or the soils types are Solonetzic, or Solodized Chernozems.

The Reserve contains an unusually high level of wildlife diversity for an upland prairie ecosystem. This is due to the lush nature of the fescue grasslands, the varied topography of the escarpment and coulees and the presence of small wetlands and aspen copses. There are a number of species in the Reserve which are important. The Baird's Sparrow, Ferruginous Hawk, Loggerhead Shrike, and Long-billed Curlew are all considered rare species in the Canadian prairies. The shoreline of Little 


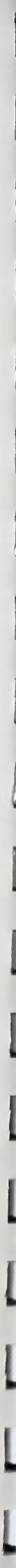


Fish Lake, which is within the Reserve, is one of the most important nesting sites in western Canada for the endangered Piping Plover.

There are a number of plant species in the Reserve which are rare in Alberta, including the Crowfoot Violet, Few-flowered Rush and Small Yellow Evening Primrose. As well, several disjunct cordilleran and prairie species are present.

There are a number of significant features in the Reserve, such as the vegetation, wildlife and landform features mentioned above. Additional significant features include a concentration of tipi rings along the escarpment and some dramatic landscapes which are rare on the Canadian prairies.

Based on a close examination of the biotic and abiotic features of the Reserve, this study makes a number of management recommendations. These recommendations concern the preservation of the fescue grasslands, the protection of rare and endangered species and the need for close monitoring of the effects of grazing and haying on the grasslands. 


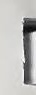




\section{Acknowledgements}

The following people made contributions to this study which guaranteed that the end product was much better than it would otherwise have been. Any errors or omissions are strictly the responsibility of the senior author.

Keith Ainsley (Resource Data Division - RDD) provided guidance for the duration of the study and reviewed the draft report.

Lucy Fafarek (RDD) provided cartographic support and digitized all the maps produced for this report.

Russ Wells (RDD) provided a lot of advice concerning the landforms and soils of the Reserve.

Richard Nesby (RDD) generously loaned a fair amount of expensive field equipment for the field work.

Kathy Schneider (Midland Provincial Park) provided general information about the Reserve, especially about the lease holders.

Peter Miloh (Natural History Department, Provincial Museum of Alberta) provided information about several buried bones unearthed during the soil survey.

Rod Vickers (Cultural Resources Department, Provincial Museum of Alberta) provided information about archaeological resources of the Hand Hills.

Bob Silverthorn (outfitter and wilderness guide, Wetaskiwin) provided information about the cultural artifacts found within the Reserve. 



\section{Table of Contents}

Executive Summary

Acknowledgements

Table of Contents

List of Maps

List of Figures

List of Tables

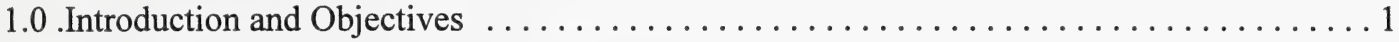

1.1 .Northern Fescue Grassland in Alberta $\ldots \ldots \ldots \ldots \ldots \ldots \ldots \ldots \ldots \ldots \ldots \ldots \ldots \ldots$

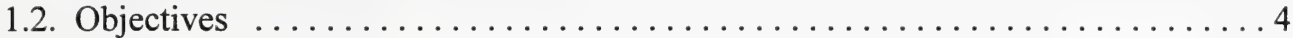

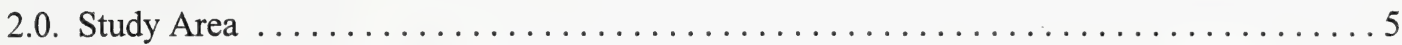

2.1. Location of the Hand Hills Ecological Reserve ...................... 5

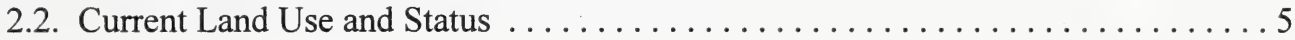

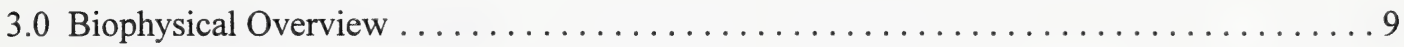

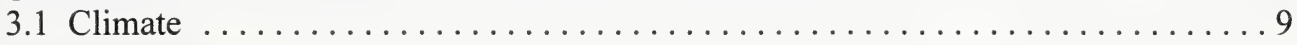

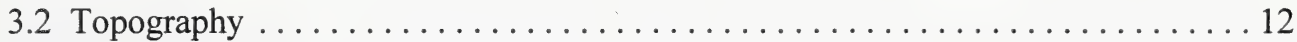

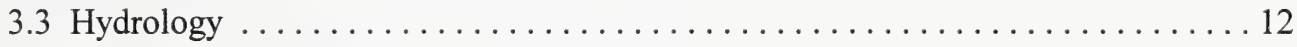

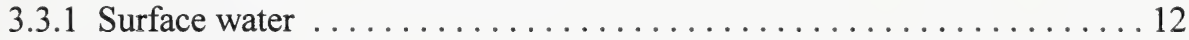

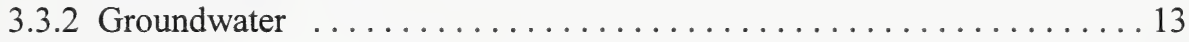

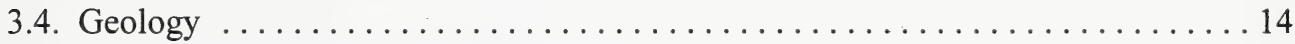

3.4.1. Bedrock and Surficial Geology ...................... 14

3.4.2. Coal Resources .............................. 15

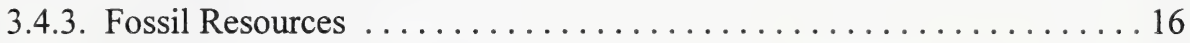

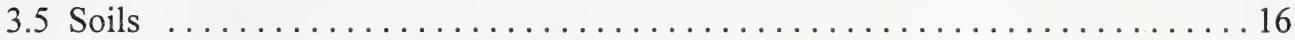

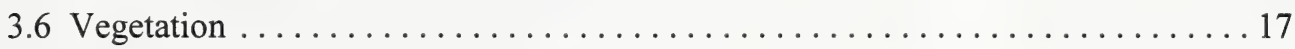

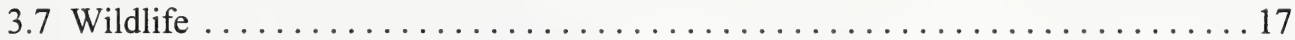

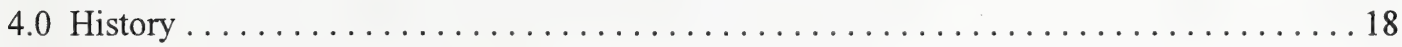

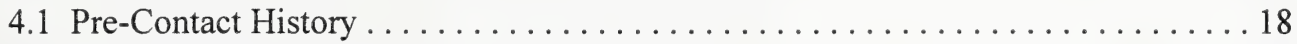

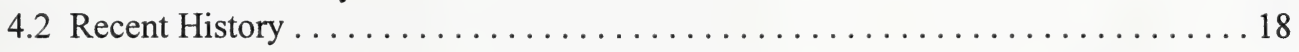

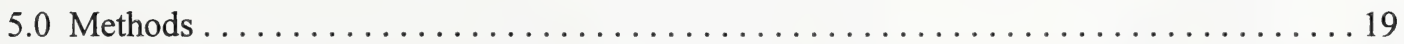

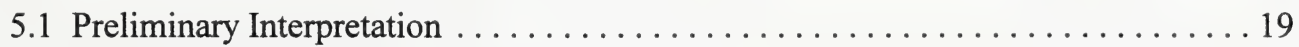

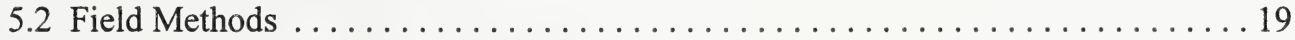

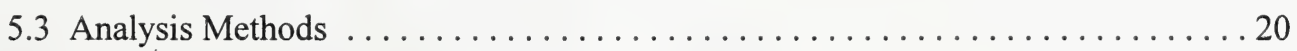

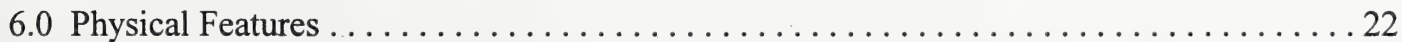

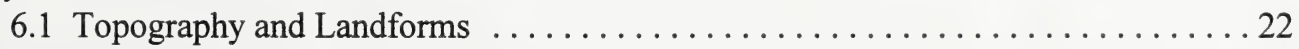

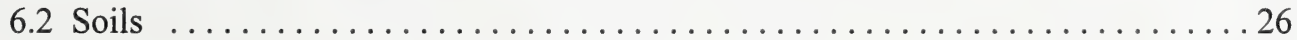

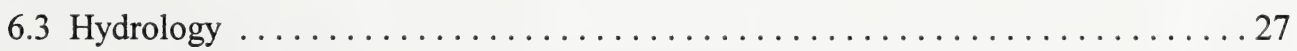




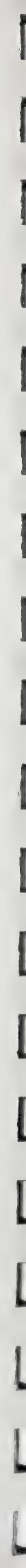




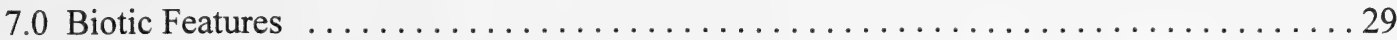

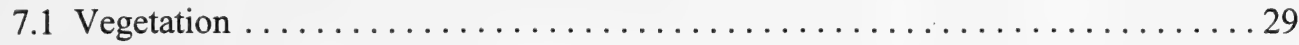

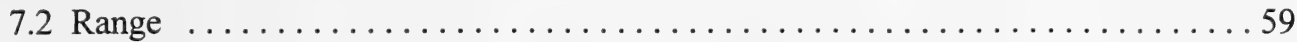

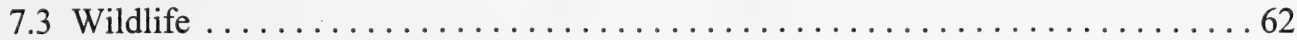

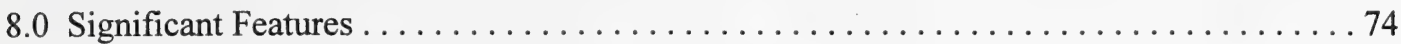

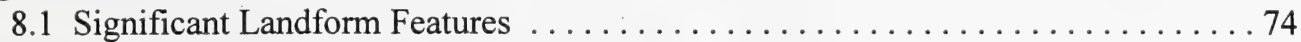

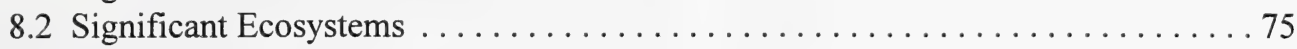

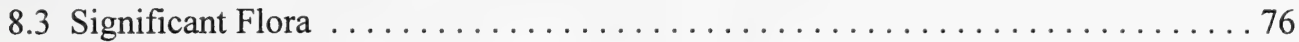

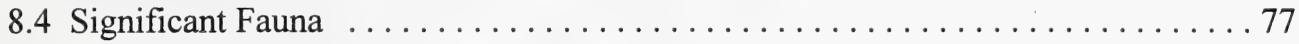

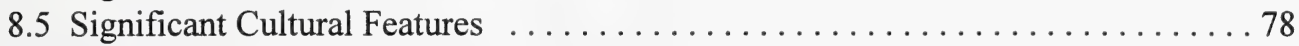

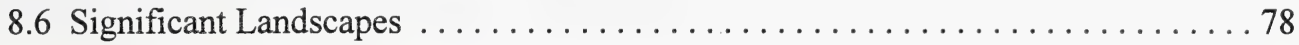

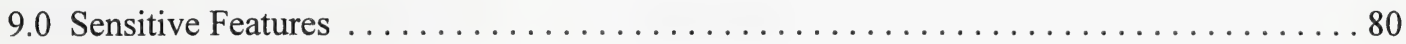

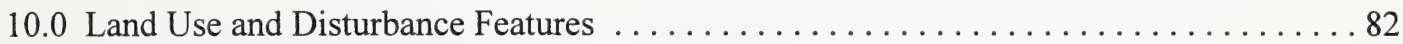

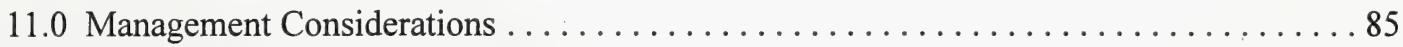

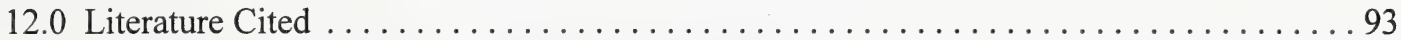

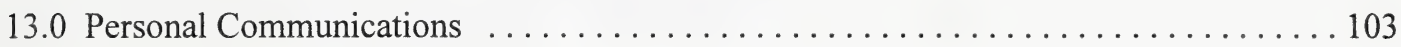

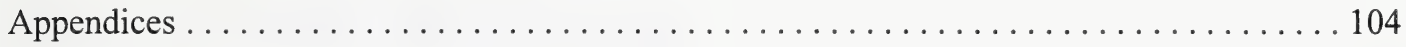

Appendix I Vegetation-Ecosite Data Sheets ............................ 105

Appendix II Annotated list of plant species . . . . . . . . . . . . . . . . . 150

Appendix III Annotated List of the Fish . . . . . . . . . . . . . . . . . . . . 158

Appendix IV Annotated List of the Herpetofauna . . . . . . . . . . . . . . . . . . . 159

Appendix V Annotated List of Birds . . . . . . . . . . . . . . . . . . . . . . 161

Appendix VI Annotated List of the Mammals . . . . . . . . . . . . . . . . . . 178

Appendix VII Annotated List of the Butterflies . . . . . . . . . . . . . . . . . 181

Appendix VIII Reserve History and Administrative Land Use . . . . . . . . . . . . . 186

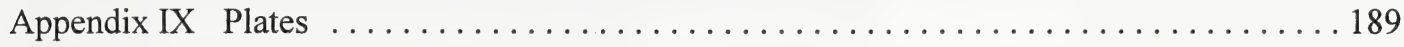

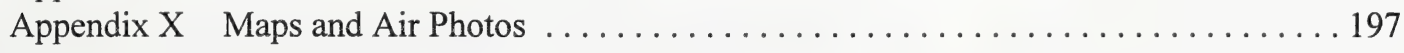





\section{List of Maps}

Study Area Location

Land Use Dispositions

Study Area

Ecological Land Classification

Range Condition

Significant and Special Features

Land Use and Disturbance Features p. 7

p. 8

back flap

back flap

back flap

back flap

back flap

\section{List of Figures}

Figure 1: Topographical profiles of the Reserve.

p. 25

\section{List of Tables}

Table 1: Plant species diversity of the vegetation communities. p. 58

Table 2: Range conditions present within each of the vegetation communities.

p. 61 



\subsection{Introduction and Objectives}

The Hand Hills Ecological Reserve was created to preserve a portion of Alberta which is quite unique. Unique in that it is an ecosystem which, in the space of a single lifetime, has declined in status from that of a broad, unbroken landscape to its current level of small, isolated and degraded patches.

The discussion below illustrates how the Hand Hills Ecological Reserve (hereafter referred to, simply, as the Reserve) has achieved this position of being both unique and typical.

\subsection{Northern Fescue Grassland in Alberta}

\section{Grasslands in Alberta}

The Prairie Grassland natural region occupies a large area in the interior of North America. Within Canada, the prairie region covers 498,027 square kilometers, a mere $5.1 \%$ of our land mass (Wiken 1986). Thirty-four percent of the prairie region of Canada is located in Alberta.

Within Alberta, this area is known as the Grassland Ecoprovince, and is divided into four ecoregions: Dry Mixed Grass, Mixed Grass, Fescue Grass and Aspen Parkland (Strong and Leggat 1992). The first three ecoregions, which form the true prairie landscape, account for 89,514 square kilometers, or $13.6 \%$ of the province.

Due to a variety of factors, such as agriculture, land development and the increasing urbanization of our landscape, it is estimated that less than five percent of the native grasslands in Canada remain in a natural state (Burnett et al 1989).

\section{Northern Fescue Region}

The Mixed Grass ecoregion of Alberta can be further divided into two ecologically distinct subregions: the Mixed Grass and Northern Fescue Grassland sub-regions (Alberta Environmental Protection 1994a).

The Northern Fescue Grassland is a narrow belt between the warmer, drier Mixed Grassland and the cooler, moister Central Aspen Parkland (Wallis 1990). It covers an area of only 15,385 sq.km., equivalent to $2.3 \%$ of the area of Alberta (Achuff 1992).

Northern Fescue Grasslands are unique in that they are found only in Canada, and no extensive areas of this prairie type remain in either Saskatchewan or Manitoba (Cottonwood Consultants 1986). Thus, Alberta is the only place in the world where large areas of Northern Fescue Grasslands occur.

This Northern Fescue region is characterized by grasslands on rolling ground moraine and 

hummocky moraine with a vegetation cover dominated by fescue grasslands. (Alberta Environmental Protection 1994a). Mixed grasslands with june grass, western porcupine grass, northern wheat grass and Hooker's oat grass, are also important components of the vegetation of this sub-region.

Even within this ecoregion fescue grasslands occur only on rich, dark soils. Unfortunately, these soils are also highly valued for agricultural purposes, with the result that the majority of fescue grasslands have been converted to croplands, with only small remnants surviving intact (Wershler and Wallis 1990, Strong and Leggat 1992).

Because of an expanding population and an intensification of land use patterns, the Northern fescue Grassland is considered to be an endangered ecosystem (Cottonwood Consultants 1986).

\section{Northern Fescue Grassland in the Hand Hills}

The Hand Hills are situated at the southern boundary of the Northern Fescue Grassland ecoregion. They encompass over 3000 hectares of largely uncultivated, native vegetation. No other extensive areas of the Northern Fescue Grassland are known in Alberta. (Cottonwood Consultants 1986). Indeed, the Hand Hills contain the largest remaining tract of Northern Fescue Grassland remaining in the world (Wallis 1990).

This degree of rarity, coupled with ongoing habitat loss and the lack of undisturbed or minimally disturbed areas in the Northern Fescue Grassland, makes the Hand Hills an extremely important representative of this ecoregion (Cottonwood Consultants 1986).

As well, all of the plant and animal species typically found in the Northern Fescue Grassland ecoregion occur in the Hand Hills (Cottonwood Consultants 1986).

\section{Northern Fescue Grassland in the Reserve}

In 1989, a reconnaissance survey of all the major blocks of fescue grassland (greater than ten sections in size) within the Northern Fescue and the southern Central Parkland ecoregions of the province was undertaken (Wershler and Wallis 1990). Only six major blocks of fescue grasslands were found, totalling 332 sections of land. Of this land, less than twenty percent was found to be in excellent condition.

These blocks of fescue grassland were found at Little Fish Lake, New Brigden, Altario-Brodo, South Sounding Lake, Hand Hills and Rumsey. Of these six blocks, the best fescue grasslands in terms of continuous lush grassland was at Little Fish Lake, an area which includes the Reserve. (Note: in this context "Hand Hills" refers to a section of the hills to the north-east of the Reserve).

The area around Little Fish Lake was found to have not only the largest tract of continuous fescue grassland but the largest remaining area of lush fescue grassland occurring on deep loamy soils. All other large tracts of fescue grassland occurred on shallow, stony soil profiles or within an aspen 

parkland mosaic (Wershler and Wallis 1990).

\section{Establishment of the Reserve}

To protect an area as rare and important as the northern fescue grasslands at Little Fish Lake, the establishment of an ecological reserve was proposed. Caza (1985) believes that the most effective method of conserving endangered habitats is through the establishment of such reserves. It is also a means of protecting rare, unusual or special features, whether they be biological, geological or geographical in nature (Chabillon 1993).

In order to protect and preserve the fescue grassland at Little Fish Lake and its unique features, the Hand Hills Ecological Reserve was established, on January 14, 1988. (For a detailed history of the establishment and administration of this Reserve, see Appendix VIII).

Ecological Reserves are nominated, established and managed according to the tenets of the Wilderness Areas, Ecological Reserves and Natural Areas Act. According to this Act, an ecological reserve can be established due to several reasons:

1. to protect a natural ecosystem,

2. to preserve rare and/or endangered plant or animal species,

3. to protect rare and/or unique biological or physical features,

4. to permit the scientific study of a natural ecosystem, and

5. to permit the study of how an ecosystem recovers from the effects of a natural or unnatural modification.

The Hand Hills Ecological Reserve fulfills all of these functions, as outlined below.

The primary aim of the Reserve, and the principal reason why it was established, is to protect a representative example of the Northern Fescue Grassland. However, it is also protecting the habitat of a number of rare and endangered plant and wildlife species, some of which are restricted to the fescue grasslands. This includes populations of Piping Plovers, Upland Sandpipers, Baird's Sparrows and Thirteen-lined Ground squirrels, as well as some rare plant species. These species contribute to an unusually high degree of biodiversity for a prairie landscape.

There are a number of physical features within the Reserve which are unique in the prairie region. For example, a series of hills in the southern portion of the Reserve forms a high and dramatic escarpment, a rare feature on what is usually a low relief landscape.

In terms of the number and quality of the natural features found in the Hand Hills, there is no other comparable site in Alberta (Wallis 1990).

Some of the biological features of the Reserve have been the subject of scientific investigations, ranging in scope from science camps for young adults to research programs carried out by university personnel. 

Most of the northern fescue grasslands found in the region are heavily grazed and support only small patches of grassland in good condition (Wershler and Wallis 1990). Because cattle grazing and haying are permitted within the Reserve, it provides a unique opportunity to examine the effects of grazing and haying on the Northern Fescue Grassland.

\subsection{Objectives}

Since the Reserve was established in 1988 , there has been an ongoing process to produce a management plan for the area. This has been an unusually long process due, in part, to a paradox which faces the Management Committee. On one hand the Committee is charged with protecting a unique and endangered ecosystem. On the other, it must allow some traditional human activities to continue within the Reserve, i.e. cattle grazing and haying. The crux of the paradox is that these activities can very easily erode and destroy the inherent values found within this ecosystem.

As an aid to finding the best compromise between these two contradictory activities, and to ensure that its management decisions are based on accurate and detailed information, the Management Committee requested this study be undertaken.

The objectives of this project are straightforward:

-to study and map the physical and ecological characteristics of the Reserve, -to find and map any significant physical or ecological features, -to determine the successional status of the native grasslands, -to determine the grazing intensity and range condition of the native grassland, and -to determine the location and extent of any disturbance features.

The level of detail required is considerable, as all information is mapped at a scale of 1:10,000. 



\subsection{Study Area}

\subsection{Location of the Hand Hills Ecological Reserve}

The Reserve is located 34 kilometers south-east of Drumheller, just north of secondary Hwy 573 (see Study Area Location map on page 7).It lies within the southern portion of the Hand Hills, immediately adjacent to the northwest shore of Little Fish Lake.

The legal land description of the Reserve is:

Twp. 28, R. 17, W4M,

Sections 10 (east half), 11, 12, 13, 14, 15 (east half), 22,

23,24 and 25 .

Any waters of Little Fish Lake, particularly those within sections 12 and 13, are not included in the Reserve. The area of the Reserve changes with the rise and fall of the lake level. When the Reserve was established, in 1988, its stated size was 2229.01 ha (5507.8 ac).

The Reserve is 22.3 square kilometers ( 8.61 sq. miles) in size, with its maximum dimensions being $6.4 \mathrm{~km}$ (north-south) by $4.8 \mathrm{~km}$ (east-west) ( 4.0 by 3.0 miles). Since the Hand Hills Upland is approximately 600 sq. $\mathrm{km}$ in area (Pedocan Land Evaluation Ltd. 1984), the Reserve includes only a small portion $(3.7 \%)$ of the Hand Hills.

The highest point of the Reserve, Thumb Hill, has a survey monument: Geodetic Survey Reference No. 716005 .

\subsection{Current Land Use and Status}

Although Ecological Reserves are set aside for a variety of purposes, conservation foremost among them, they are not usually subject to ongoing human activities. However, the Hand Hills have long been used for agricultural purposes. In the prairie region, cattle grazing is an important land use where there is insufficient water for crop production (Strong and Leggat 1992). This is certainly true of the Hand Hills, where cattle grazing has played an important part in the local history. The lands within the Reserve have traditionally been used for grazing and haying (for more information on the history of the Reserve, see appendix VIII).

One of the unique characteristics of this Reserve is an agreement between the Alberta government and the leaseholders such that grazing will continue within the Reserve. Most of the Reserve is being actively grazed (see Land Use Dispositions map on page 8).

The only other land use within the Reserve is haying. Section 25 is currently under three Farm Development Leases, all of which are restricted to haying only. As well, two leases within section 11 are also restricted to haying. 

The Land Use Dispositions map shows the location and names of the current lessees in the Reserve.

There are three PNG (Petroleum and Natural Gas) leases for parts of the Reserve. However, none of them is accessible from Reserve lands.

\section{Land Administration}

Section 25 of the Reserve lies within the Municipal District of Starland (No. 47) and is administered by Public Lands Services, Department of Agriculture, Food and Rural Development. All other lands within the Reserve are administered by the Special Areas Board of the Department of Municipal Affairs. 



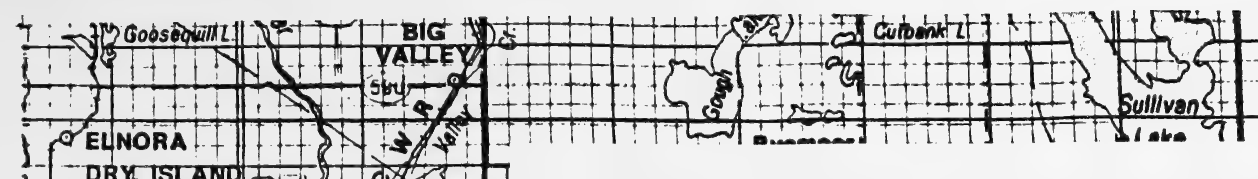

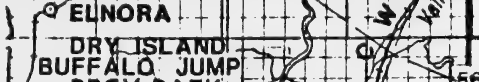
BUFFALO JUMP Location of the Hand Hills Ecological Reserve if: 1 scollard Equity

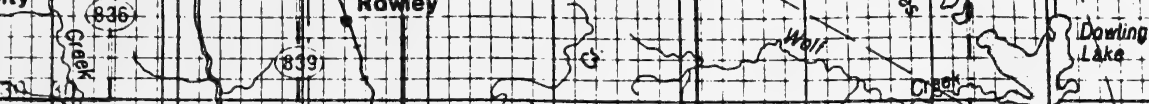
If

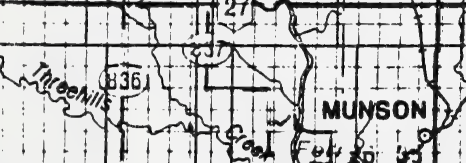

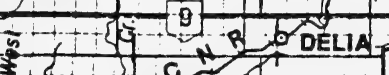
LAR Mond Hills
Gatly

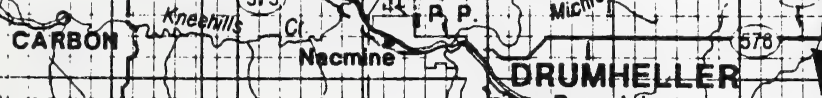
$1 \frac{1}{1365}$

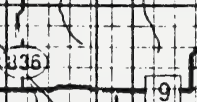

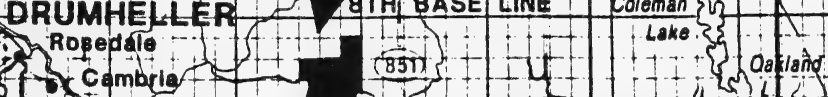 Wweyne Thaung L b t

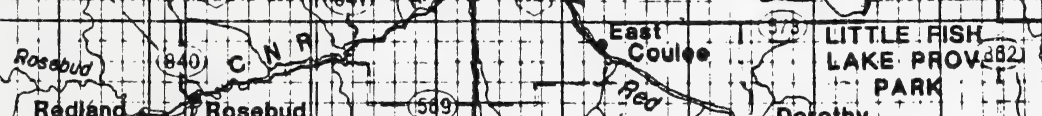

Ronten (5) if Sor antree

stanoafá $x+1+x$

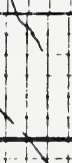
$1+$

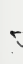
 (1) $56]$
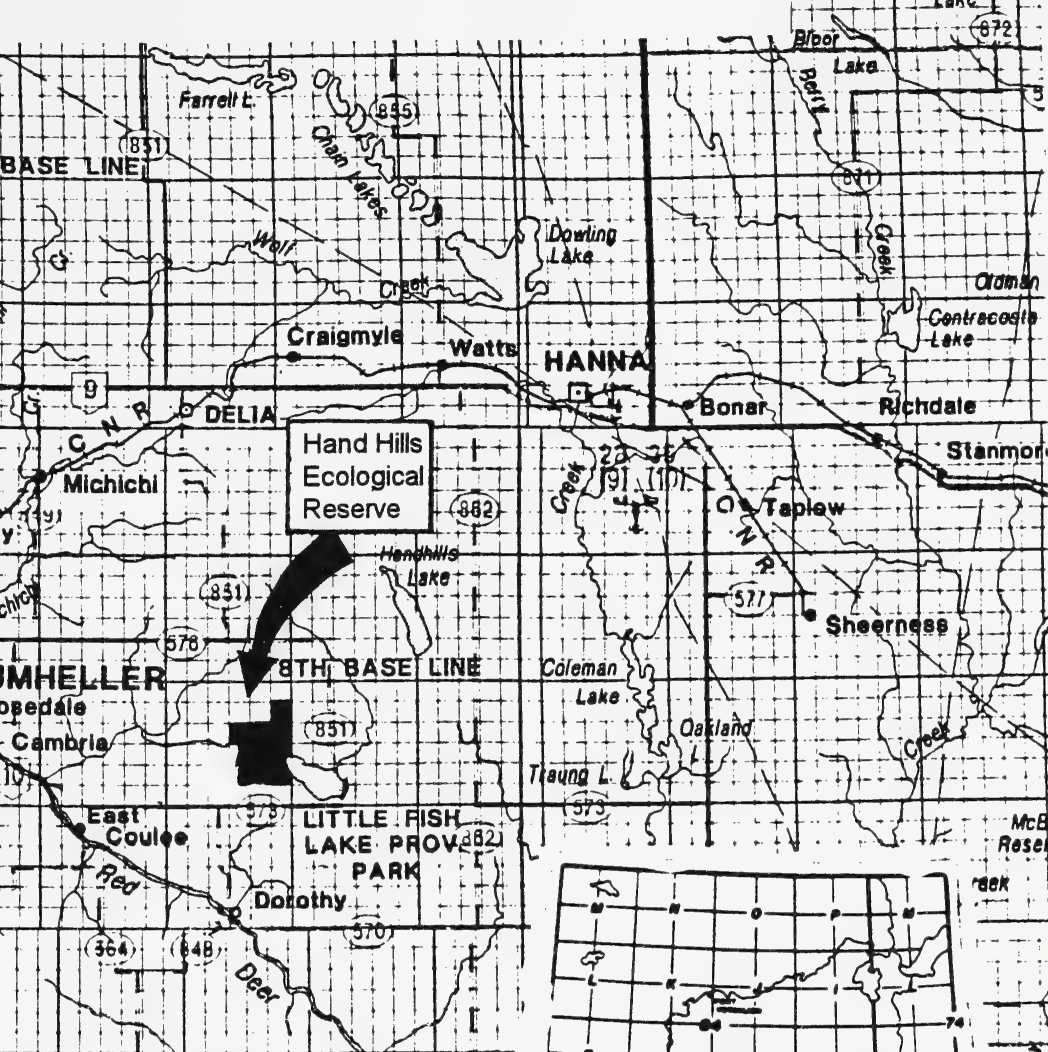

HAND HILL ECOLOGICAL RESERVE

H

FDL $\quad 790478$

AGRICULTURAL LAND DISPOSITIONS

All lands in Reserve are within Twp28R17W4

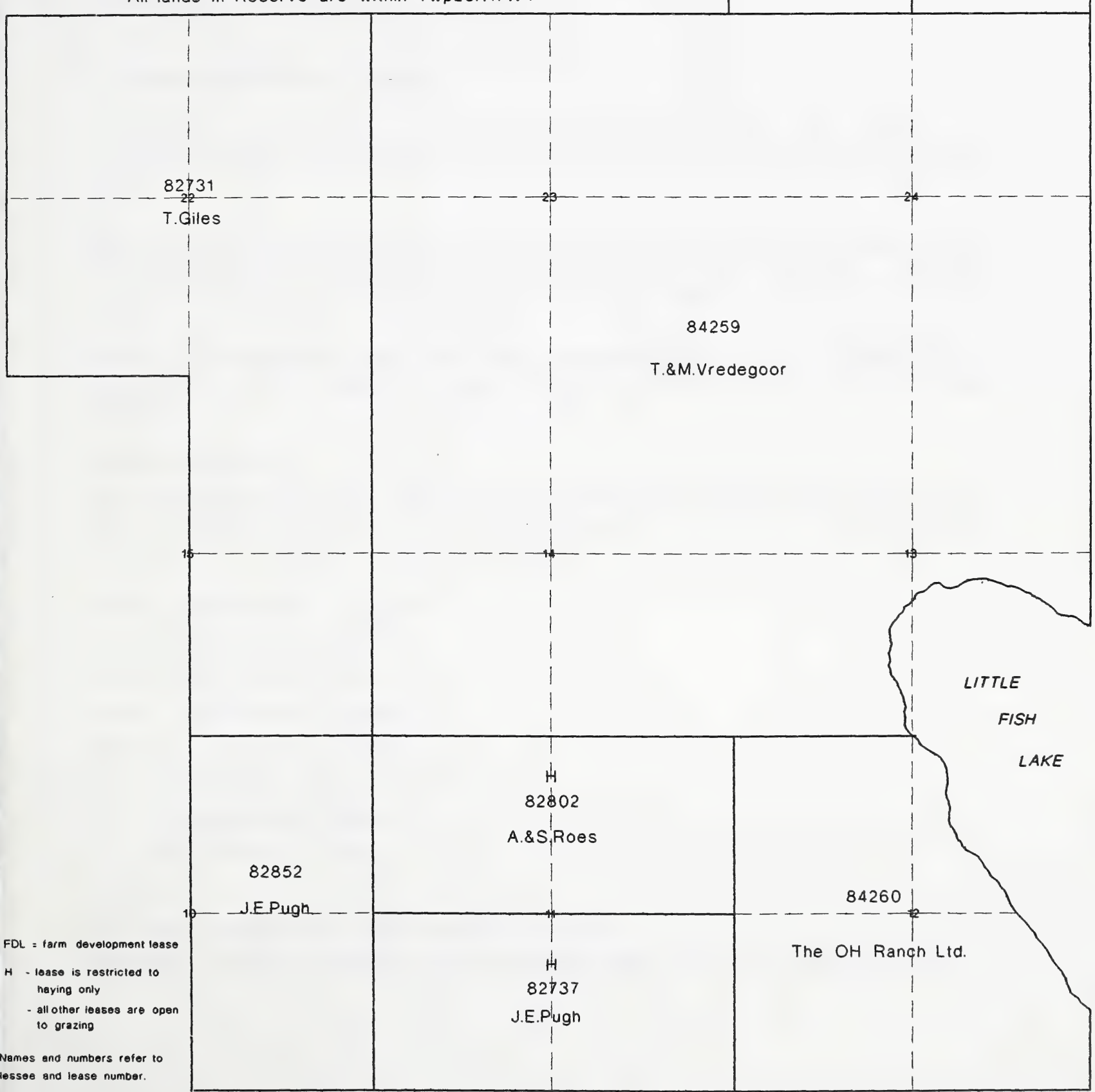





\subsection{Biophysical Overview}

The information presented in this section provides an overview of the physical and ecological characteristics of the region in which the Reserve occurs and summarizes the existing information for the area around and within the Reserve. The scope of this information covers a broad geographic scale, from the ecoregion level down to the small area occupied by the Reserve.

This information was taken from the literature.

\subsection{Biophysical Overview - Climate}

The Grassland ecoregion is subject to a continental-type climate (Strong and Leggat (1992) which, as in much of Alberta, is characterized by long, cold winters and short, cool summers (Phillips 1990).

Within the south-central region of Alberta, the Northern Fescue subregion has a meso-climate which is transitional between the warmer and drier Mixed Grass subregion to the south and the cooler and moister Central Aspen Parkland subregion to the north (Achuff 1992).

The Hand Hills themselves are likely to have cooler average temperatures than the Northern Fescue subregion due to their considerably higher topographic position relative to the surrounding countryside.

\section{Annual weather cycle}

The average annual weather cycle for the area near the Hand Hills was determined by Masterton et. al. (1976) and is provided below. This information was derived from data taken from the weather station in Drumheller, the nearest station to the Hand Hills.

First day of winter season: November 1.

Last day of winter season: April 25.

First day of spring shoulder: May 10.

First day of high summer: May 18.

Last day of high summer: September 15.

Duration of winter season: 176 days.

Duration of complete summer: 175 days

-spring shoulder: 8 days

-autumn shoulder: 46 days

-high summer: 121 days.

(Note:

-winter season: median dates with at least one inch of snow.

-high summer: period over which the daily mean maximum temperature was 65 degree $\mathrm{F}$ or greater). 

It should be noted that these dates and season durations are mean values and that weather patterns can show extreme variations between years. Surprise events, such as May snowfalls followed by sudden heat waves, have been known to occur in the area (Phillips 1990).

\section{Precipitation (rain)}

The rainy season for this part of Alberta extends from late May until early September (Phillips 1990). Most of this rain falls in June, which corresponds to the early part of the growing season (Strong and Leggat 1992).

Rainfall in this area is approximately twenty percent higher than it is in the Dry Mixed Grass region to the south, mainly due to closer proximity to the storm tracks in central Alberta (Strong and Leggat 1992). These storm tracks usually shift northwards in July and August with a resulting decrease in precipitation. However, rainfall in this region does show extreme yearly variation such that there may be a drought one year and excessive rainfall the next (Phillips 1990).

\section{Precipitation (snow)}

Like rainfall, snowfall and the presence of snowcover varies greatly from one year to the next. According to Masterton et al (1976) the mean snow cover and depth for the region is:

First day of reliable snow cover: Nov 26

Last day of reliable snow cover: March 26.

Duration of reliable snow cover: 122 days

Mean snow cover depth, Feb 28: 5 inches.

Mean snow cover depth, March 31: 0 inches.

(This climate data was taken from the Drumheller station)

The duration of reliable snow cover is defined by the first and last dates between which snow remains on the ground for at least seven consecutive days. The termination of reliable snow cover is difficult to determine in southern Alberta due to the effects of elevation and, especially, chinooks (Masterton et al 1976).

Because the Reserve is located on an elevated plateau and has a varied topography, ranging from exposed hilltops to deep, sheltered coulees, the snow cover would also exhibit great variation, both in depth and duration.

In areas of moderate to high wind conditions, snow cover is distributed unevenly, i.e., drifts in some areas and bare, snow-free ground in other areas. Grassland areas exert a strong influence on the snow cover. As a result, the amount of snow cover across the Reserve would vary considerably.

In southern Alberta, snow cover generally reaches its maximum in February, but on average in less than twenty centimeters (Phillips 1990). 



\section{Storms (summer)}

Central Alberta, with the Hand Hills at its southern edge, experiences some of the most severe thunderstorms and associated hailstorms in the world (Phillips 1990).

There are, on average, between twenty and twenty-five days of thunderstorms each year (Phillips 1990) with the frequency of hail days greatest in June and July (Papirnik et al 1990). Based on twenty-nine years of records, the Alberta Hail Project Area, which is located just to the north of the Reserve, experienced an average of sixty hail days per year with large hail (larger than walnut size) present on thirty-nine percent of all hail days (Papernik et al 1990). The frequency of large hail was highest in late July, with crop damage caused by hail reported most often between mid-July and the end of August (Papernik et al 1990).

Thunderstorm activity drops to less than one day per month by September, with very few hail events (Phillips 1990).

The mean number of days with lightning during the summer period was determined by Harvey (1977):

May: 2

June: 7

July: 9

Aug: 8

Sept: 3

The mean seasonal cumulative lightning incidence, from May to September was 30 days.

\section{Storms (winter)}

Blizzards in the Hand Hills region are most likely to occur in February (Phillips 1990). The loss of wildlife and livestock during these prairie blizzards can be severe (Masterton et al 1976).

\section{Wind}

The most important wind events in the Hand Hills region are the chinooks. These are warm, dry winds which can be accompanied by spectacular increases in temperature and decreases in humidity over very short periods of time (Masterton et al 1976). In fact, temperature changes of twenty degrees Celsius in less than an hour are possible, with the result that areas within the influence of strong chinooks can often be laid bare several times in a single winter (Phillips 1990).

Longley (1967) found that there was, on average, fourteen days with noticeable chinook events in the Hand Hills region during the winter period (December, January and February).

Although chinooks can alleviate cold winter temperatures, they have major disadvantages. The loss of snow cover means that there is decreased soil moisture and an increased risk of soil erosion (Phillips 1990). Overall, the landscape and soils of the Hand Hills have a low erosive potential (Geitz 1983). 



\section{Agroclimate}

The Reserve is located within an agroclimatic zone in which rainfall is a limiting factor for plant growth fifty percent of the time, and where the frost free period lasts more than ninety days (Bowser 1967). The adjoining agroclimatic zone to the north has a similar frost free period but with adequate rainfall, and the adjoining zone to the south has a similar rainfall level but a longer frost free period (100 days).

\subsection{Biophysical Overview - Topography}

The Northern Fescue Subregion is characterized by a gently rolling landscape (Achuff 1992). Because this rather smooth landscape is broken only by occasional uplands or deeply incised river valleys, the Hand Hills are a prominent topographic feature of this subregion.

The Hand Hills are a remnant plateau, one of the few areas on the prairies to survive extensive glacial erosion during the Wisconsin glaciation (Wallis 1990). They rise approximately 200 metres above the surrounding prairie, giving them a cooler and moister climate than is normally found in this region.

The western perimeter of the Hand Hills is marked by an abrupt and, in most places, steep escarpment. The Reserve is located in the southwest corner of the Hand Hills, where the escarpment is approximately $96 \mathrm{~m}$ ( 315 feet) high (see plate 1$)$.

The highest point in the Reserve is Thumb Hill, at 986 meters ( 3235 feet) above sea level. This is 146 meters (479 feet) above the surrounding countryside.

\subsection{Biophysical Overview - Hydrology}

\subsubsection{Surface water}

The Hand Hills has only two major waterbodies: Hand Hills Lake, which lies $9.6 \mathrm{~km}$ (6 miles) to the northeast of the Reserve, and Little Fish Lake, which forms part of the eastern boundary of the Reserve.

In the area immediately surrounding the Reserve, water flows into Little Fish Lake mainly from the north, via Fish Creek (McIntyre 1990). The main outflow of Little Fish Lake is a small creek which bisects the Reserve from east to west. Most of the land within the Reserve is drained by this creek, a tributary of Willow Creek, which then flows into the nearby Red Deer River.

Little Fish Lake is a typical prairie lake in that it's water level experiences wide fluctuations from year to year. Water levels were high in the mid-1960's, to the extent that shoreline erosion was a problem at the mouth of the outlet channel (McIntyre 1990). Water levels have decreased since that 

time, despite the construction of a weir at the mouth of the outlet channel in 1966. (See Section 10 for more information about the weir). Between 1975 and 1989 the mean water level decreased by $3.4 \mathrm{~m}$ (McIntyre 1990) and has remained low since that time. There has been no surface outflow from the lake since the early to mid 1960's (Monenco Consultants Ltd. 1987).

This long-term trend of low water levels is probably a natural event, caused by decreased precipitation and increased evaporation over the last three decades (McIntyre 1990).

Even within a single summer season, the position of the shoreline can vary widely, depending on local precipitation levels. This is an important consideration as the legal boundary of the Reserve includes all lands within Sections 12 and 13 which are covered by the basin of Little Fish Lake. As the water level fluctuates, so does the boundary of the Reserve.

Previous work done in the Reserve (Cottonwood Consultants 1986, Wallis 1990) found that the upland sites were well-drained while low-lying areas were poorly drained. All surface water is intermittent, with most of the sloughs, ponds and streams being seasonal in nature, i.e. full only in spring or following periods of rainfall.

\subsubsection{Groundwater}

According to Vanden Berg and Lennox (1969) the Bearpaw Formation, which underlies all of the Hand Hills, contains a relatively impermeable deposit of marine shale. It effectively prevents most downward movement of groundwater.

Above this layer is the Edmonton Formation, with alternating beds of shale, coal and argillaceous sandstone. Most of the groundwater recharge in the Hand Hills area moves through this formation, principally via the permeable coal beds. Farm wells in the vicinity of Handhills Lake draw their water from these layers but usually at less than five gallons per minute (Vanden Berg and Lennox 1969).

The Tertiary strata of the Paskapoo Formation, which overlies the Edmonton Formation, has thick local deposits of highly permeable sandstone.

Two observation groundwater wells, in operation from October, 1965, until at least the end of 1981, were located ten kilometres (six miles) northeast of the Reserve, near Handhills Lake (Gabert 1986). (The water levels in these wells is considered a close approximation of the water table).

One well was pumping water from within shale and coal layers in the Edmonton Formation. The well was 96 metres ( 315 feet) deep and the depth to water was 79 metres ( 260 feet). The other well was pumping water from sandstone material of the Paskapoo Formation. The well head was at 41 metres (133 feet) and the depth to water was 36 metres (118 feet). 

Over the course of the recording period the water level in both wells dropped, in the Edmonton Formation by two metres and in the Paskapoo Formation by one meter. Natural fluctuations in groundwater levels are the result of active hydrologic processes, such as precipitation, evaporation, runoff and water infiltration (Gabert 1986). The decrease in water levels in these two wells may be a response to the same environmental factors which are causing the low water levels in Little Fish Lake.

\subsection{Biophysical Overview - Geology}

\subsubsection{Bedrock and Surficial Geology}

Most of the southern and central prairie region of Alberta is underlain by strata of the Cretaceous and Tertiary periods (Pawluk and Bayrock 1969). According to Campbell (1974) and Vanden Berg and Lennox (1969) the characteristics of the bedrock and surficial deposits beneath the Hand Hills are as follows.

The upper level of the Bearpaw Formation lies 274 meters (900 feet) below the surface and is approximately 168 meters (550 feet) thick. It is a Late Cretaceous marine deposit composed mainly of shale.

Overlying this layer is the Edmonton Formation. It is approximately 198 meters (650 feet) thick and rises to within 76 metres (250 feet) of the surface. It is also Late Cretaceous in age but is a continental deposit, composed of alternating beds of shale, argillaceous sandstone and coal. Within the upper part of this formation is the Kneehills Member, a layer of highly bentonitic shale. Although it is a fairly thin layer (10 to 18 meters) it is noted as a persistent, widespread and highly recognizable marker for the Edmonton Formation.

The uppermost major bedrock deposit is the Paskapoo Formation, which comprises the top 76 meters ( 250 feet) of the mantle. It is Early Tertiary in age and composed of arenaceous sediments, notably massive cross-bedded cliff-forming sandstones. In the Hand Hills area the basal 60 meters (200 feet) of this formation consists of argillaceous coal-bearing strata. The upper surface of the Paskapoo Formation is usually the current erosional surface except where it is overlain by later Tertiary deposits (Glass 1990).

The surficial deposits of the Hand Hills are notable for a number of reasons. Because of the widespread erosion associated with the Wisconsin glaciation, the presence of Tertiary deposits is rare in Alberta, especially in the prairie region. There are, to date, only ten remnant Tertiary plateaux known in Alberta, three of them in the prairie region: Cypress Hills, Wintering Hills and Hand Hills (Storer 1978).

The Tertiary conglomerate outcrops in the Hand Hills are composed of sandstone and quartzite gravels cemented with calcium carbonates (Cottonwood Consultants 1986). The presence of these 

bedrock outcroppings is considered local and rare on the prairies (Wallis 1990).

Overlying this consolidated bedrock is a layer referred to as the Tertiary gravels. It some localities it forms an abrupt and disconformable deposit overtop of the Paskapoo Formation (Glass 1990). Composed chiefly of quartzite and chert they range in age from Middle Miocene (the lower gravels) to Pleistocene, and are partially intermixed with Laurentide drift materials, i.e. morainal deposits.

Along with these Tertiary gravels are local deposits of marl and sand (Vanden Berg and Lennox 1969).

An isopach map of the surficial deposits near Handhills Lake shows that they vary in thickness from 6 to 12 meters (20 to 75 feet) (Vanden Berg and Lennox 1969). They consist primarily of ground moraine and alluvium (sand and gravel). The Reserve is also covered with these same deposits. A mixture of coarse and fine grained morainal materials dominates most of the Reserve with some localized sandy and gravelly glaciofluvial deposits (Cottonwood Consultants 1986, Wallis 1990).

\subsubsection{Coal Resources}

An Energy Resources Conservation Board report (ERCB 1994) lists two coal deposits lying beneath the Reserve which have some commercial potential. The information on these coal "fields" is given below.

Drumheller coal field, North Handhills (deposit no. 10):

A. Surface mineable deposit: 14 megatonnes (estimate), with an average thickness of 1.6 meters (5 feet), spread over 6.0 sq.km. (2.3 sq.mi.). Ranges in depth from 13 to 28 meters (43 to 92 feet).

B. Underground-mineable deposit: thin; 113 megatonnes (estimate), with an average thicknes of 1.7 meters ( 6 feet), spread over 47.7 sq.km. (18.4 sq.mi.). Ranges in depth from 13 to 147 meters (43 to 482 feet).

Both of these deposits are rated as subbituminous $\mathrm{B} / \mathrm{C}$ coal.

Drumheller coal field. Little Fish deposit (deposit no. 11):

A. Underground-mineable deposit: thin; 78 megatonnes (estimate), with an average thickness of 1.4 meters ( 5 feet), spread over 38.5 sq.km. (14.9 sq.mi.). Ranges in depth from 18 to 133 meters (59 to 436 feet). This deposit is rated as subbituminous B coal.

Two small mines are believed to have extracted coal in an area two townships directly north of the Reserve (Campbell 1974) although no dates could be found for the operation of these mines. 



\subsubsection{Fossil Resources}

The Hand Hills are a well known locality for Tertiary fossils. Russell (1958) reported the discovery of a specimen of horse, Astragalus, from the conglomerate layer. Other mammals include a Pleistocene camelid found in the gravels of the eastern Hand Hills, and several Middle Miocene species from the Barstovian (Clarendonian) fauna, such as Hipparion, Leptodontomys, Copemys and Merychippus (Storer 1978).

A rich bed of vertebrate fossils was discovered several miles north of the Reserve in 1984. This find, which included abundant specimens of Amia and Champosaurus, was located just beneath the Tertiary gravels, in a bed of shales and siltstones (Fox 1988). Another find of vertebrate bone and molluscan shells in 1986, in a shale deposit approximately 22 meters below the previous find, made this site especially important. These two fossil bearing layers were found in superposition, an uncommon relationship for mammalian occurrences in the Paleocene fauna of western Canada (Fox 1988).

The north slope of the Hand Hills has also yielded some fossil mammalian teeth, from within layers of bentonitic shales (Fox 1988).

\subsection{Biophysical Overview - Soils}

The Hand Hills lie within the Dark Brown soil zone, where the soils are predominantly Dark Brown and Black Chernozems, with minor portions of Brown Solonetzic soils (Achuff 1992).

According to the Canada Soil Inventory (1988) the dominant soil landscape for the Hand Hills is well to moderately-well drained Dark Brown Chernozems, usually with clay loam textures on morainal parent materials. The subdominant soil landscape is moderately-well drained Dark Brown Solonetzic soils, also with clay loam textures on morainal parent materials.

Wallis (1990) found that finer-grained Dark Brown Chernozems were found on the upland areas of the Reserve while coarser grained Dark Brown Chernozems were found on sandy and gravelly glaciofluvial deposits. The Dark Brown Solonetzic soils within the Reserve occurred on fine textured morainal or glaciofluvial material. Where soils became saturated due to seasonal flooding, fine textured gleyed Chernozems and Gleysols were present.

According to a map of soil salinity for Alberta (Pettapiece and Eilers 1990) less than $0.1 \%$ of the Reserve is affected by soil salinity. For the dissected slopes below the escarpment, and perhaps some slopes within the large coulees along the western boundary of the Reserve, between $0.1 \%$ and $0.9 \%$ of these areas are affected by surface salinity. Localized surface soil salinity should also be found along the edge of drainage-ways and ephemeral water channels. 



\subsection{Biophysical Overview - Vegetation}

The Hand Hills lie within the Northern Fescue Grassland, a narrow ecosystem between the warmer, drier Mixed Grassland to the south and the cooler, moister Central Aspen Parkland to the north (Wallis 1990).

The typical vegetation of this region is rough fescue-mixed grass grass, on rolling ground moraine and hummocky moraine (Alberta Environmental Protection 1994a). Lush fescue grasslands occur only on dark loamy soils. On lesser sites, mixed grasslands are formed with a variety of species, including northern wheat grass, june grass, western porcupine grass, and Hooker's oat grass.

The Hand Hills are situated at the southern boundary of the Northern Fescue Grassland ecoregion so vegetation communities on drier sites resemble those found in the Mixedgrass Natural Subregion (Achuff 1994).

All of the plant species typically found in the Northern Fescue Grassland ecoregion occur in the Hand Hills (Cottonwood Consultants 1986).

\subsection{Biophysical Overview - Wildlife}

There are no animal species which are restricted to the Northern Fescue ecoregion, and the overall composition of the faunal community is similar to that of the Mixed Grass ecoregion (Achuff 1992). All wildlife species which are typical of northern fescue grasslands can be found in the Hand Hills, including more than 130 bird species, and a variety of herpetofauna and mammals (Wallis 1990). At one time, the fescue grasslands of the Hand Hills and surrounding area produced large numbers of plains bison (Strong and Leggat 1992), a fact also in evidence by the use of these hills as an important traditional camping and hunting ground for native peoples (Hand Hills Book Committee 1968).

Although Little Fish Lake is not within the legal administrative boundaries of the Reserve, its overflow waters traditionally moved through the Reserve, along an obvious outlet channel. So fish species in the lake could conceivably be found in the Reserve at some time in the future. (Note: water levels in the lake have been very low for a number of years, part of a natural cycle. See section 3.3.1 for more information).

According to McIntyre (1990) Little Fish Lake had abundant populations of northern pike, white suckers, sauger and yellow perch until about 1970. Since the current low-water cycle started in the mid-1960's, fish populations have dropped to the point where, by 1985 , only a few yellow perch were still present. Past fish population must have been much higher since early settlers to the area reported a tradtional camp along the shore of Little Fish Lake used by native peoples for drying fish from the lake and nearby creek (Hand Hills Book Committee 1968). 

Little Fish Lake, and the mudflats surrounding it (which are within the Reserve) are an important staging area for both waterfowl and shorebirds during fall migration.

\subsection{History}

\subsection{Pre-Contact History}

Oral and written evidence suggests that the Hand Hills were a favoured area for seasonal use by native groups. They would most likely have been present in the spring and fall for bison hunts, when herds could be encircled and driven over cliffs along the edge of the hills (Cottonwood 1991). Certainly, the Hand Hills were used for a long period of time as a hunting and battle ground by three Indian tribes: the Blackfoot, Cree and Assiniboine (Hand Hills Book Committee 1968).

The name "Hand Hills" comes from the native word Michichi, which means Little Hand. Michichi was a Blackfoot from the Hand Hills area who was born with a shrunken and misshapen hand which resembled an animal's claw, an anomaly which resulted in his being named "Little Hand". He became a great warrior and chief of the Blackfoot Nation, and he was killed somewhere in the Hand Hills.

Many Indian camps have been found in the Hand Hills, ranging in size from about ten tipi rings to dozens (Hand Hills Book Committee 1968). One of these camps was still being used near the Lake of the Little Fishes (now called Little Fish lake) when the first settlers arrived in the area. Stories passed down from these settlers say that the camp was used to dry and smoke fish from the lake and nearby creek.

By 1800 the three tribes of the Blackfoot Confederacy, the Blackfoot, Bloods and Peigans, dominated the prairie region of Alberta, and the Hand Hills was well known as a hunting and camping spot (MacGregor 1972).

\subsection{Recent History}

Peter Fidler was the first white man to see the Hand Hills. In February of 1793, from a point just south of Stettler, he climbed a small hillock and saw, in the far distance, a low rise of hills, prominent above the surrounding prairie (MacGregor 1966). He used these hills as a survey point for the first map of the region, which he was constructing at the time. He went no closer to the hills than this point.

By 1799, the Hand Hills were a well known landmark on the prairies to the white fur traders (MacGregor 1972).

It is not known for sure when the first settlers moved into the Hand Hills area. Since commercial cattle ranching began in southern Alberta around the year 1881 (Miller 1972), it can be assumed that 

settlers probably moved into the area in the latter stages of the 19th century.

\subsection{Methods}

\subsection{Preliminary Interpretation}

Preliminary mapping of the landforms, vegetation communities, land use patterns and disturbance features was done using 1:20,000 color infrared aerial photography. (See Appendix X for details regarding maps and aerial photography used in the production of this report). These airphotos were also used during the first field trip to the Reserve. Subsequent to this trip, aerial photography flown especially for this study was made available and used for further refinement in the mapping and also during additional field trips. These photos included 1:10,000 and 1:40,000 black and white photography.

\subsection{Field Methods}

During the summer of 1996, three trips were made to the Reserve to collect the information used in this study: June 28 to July 5, July 15 to 17 , and August 12 to 18 . A total of 27 person-days were spent in the Reserve doing fieldwork.

Field data were gathered through intensive surveys of selected sites which, taken together, represented the range of landform, soil and vegetation types found within the Reserve. The information was gathered according to procedures outlined in the Ecological Land Survey Site Description Manual (Alberta Environmental Protection 1994b).

At most sites three forms were used to record pertinent information. The overall site was described using the Site Description Form (LISD 15B) and soils information was recorded using the Soil Description Form (LISD 16B). Vegetation data and range information was recorded on one of three forms: the Grazing Inventory Form - Alberta Guide (LC 55), the Vegetation Inventory Form (MF5) or the Vegetation Description Form (LISD 14B). These three vegetation forms can be used interchangeably for describing communities but only information gathered with the LISD 14B and MF5 forms were used to determine range condition.

A total of sixty-five sites were examined. At some sites, only site and soil or site and vegetation/range information was recorded. This was done as a method to quickly fill in perceived information gaps. A summary of the level of data collected by type is as follows: 



$\begin{array}{lc}\text { Information type collected } & \text { No. of Sites } \\ \text { site, soils and vegetation/range } & 23 \\ \text { site and soils } & 18 \\ \text { site and vegetation/range } & 20 \\ \text { vegetation/range } & 3 \\ \text { soils } & 1 \\ & \\ \text { Information type collected } & \text { No. of sites } \\ \text { site } & 61 \\ \text { soils } & 42 \\ \text { vegetation/range } & 46\end{array}$

The soils were surveyed using soil pits excavated to within the $\mathrm{C}$ horizon and described using the standard methods of the Canadian System of Soil Classification (Canada Soil Survey Committee 1978).

Vegetation in the grasslands was sampled using nested microplots along ten meter transects. At each site, a series of 10 microplots spaced approximately two meters apart was established. Within each microplot, all plant species were recorded and percent canopy cover was estimated. Species cover values for shrubs were estimated from $1 \mathrm{~m} \times 5 \mathrm{~m}$ microplots, whereas for forbs and grasses, daubenmire microplots $20 \mathrm{~cm}$ X $50 \mathrm{~cm}$ in size were used. Microplot data were averaged for each grassland transect.

In treed areas, surveys followed the methods outlined in the Ecological Land Survey Site Description Manual (Alberta Environmental Protection 1994b). The sampled area for the tree layer was 20m X $20 \mathrm{~m}$, with a nested plot $10 \mathrm{~m}$ by $10 \mathrm{~m}$ for estimation of cover values for all other vegetation layers.

No systematic surveys of wildlife were carried out but information on wildlife sightings and habitat was recorded as other field work was being done.

The official boundary of the Reserve in sections 12 and 13 change as the water level of Little Fish Lake rises and falls. For the purposes of this report, the boundary of the study area in these sections was taken to be the raised shoreline which marks the highest water level. It is an obvious feature, being a steep shoreline, generally $1.5 \mathrm{~m}$ to $2.0 \mathrm{~m}$ in height.

\subsection{Analysis Methods}

The field data were analyzed to provide the required information for an ecological land classification (ELC) of the Reserve. The ecological land survey method is useful for several reasons (FEARO nd., Rowe 1979). First, it is an integrated approach to classifying a landscape, which encompasses the cumulative effects of three main environmental variables: geomorphic landform, soils and 

vegetation. Second, it allows the researcher to partition the landscape into distinctive biological and physical units, a highly useful tool in environmental research. These three variables are strongly interrrelated and the classification of any one will result in the partial classification of the other two (Knapik and Westworth 1984). Third, this method will allow land managers to accurately monitor changes in the landscape and predict the possible effects of environmental perturbations.

The landforms were categorized according to Kocaoglu (1990) and the Canadian System of Soil Classification (Canada Soil Survey Committee 1978). This latter authority was also used to classify the soils of the Reserve to the subgroup level.

The vegetation data was analyzed using the computer program Twinspan, which ranked the survey sites based on their similarity to each other in terms of species cover values. Thus, sites of similar species composition were consolidated into vegetation community types. The results were then reassessed and adjusted to more closely reflect the vegetation associations as they are found in the Reserve. Species composition of each community type was then based on an average of the species cover values of the grouped sites.

Assessment of range condition was done following guidelines developed by Wroe et al (1988). This method compares the species composition at a site to a defined natural climax community, given various soil textures and precipation zones. The vegetation data was used to assess the range condition.

Mapping for this study was done at a scale of 1:10,000. At this level of generalization, the characteristics of each ecosite are as follows:

Landform: a local geomorphic feature or portion thereof.

Soils: a soil series or an association of series.

Vegetation: a single plant community.

The ecological mapping of prairie landscapes is a difficult undertaking given the nature of grassland communities. Thus, it is entirely possible that more than one vegetation community exits within each ecosite. These smaller components of the vegetation mosaic are simply too small to map at this scale. Each ecosite has been distinguished on the basis of a single landform type, one (or a combination of two) soil type(s) and one (or combination of two) vegetation community(ies).

The range map was produced as an offshoot of the ELC map, using mainly the vegetation information contained therein. 



\subsection{Physical Features}

\subsection{Topography and Landforms}

The landforms and topography of the Reserve are highly varied, more so than is usually found in a prairie landscape. This is due to the fact that the Reserve is situated on the top of a plateau. (Note: the landforms of the Reserve are mapped on the Ecological Land Classification map).

\section{Southern Highlands and Escarpment}

The most obvious topographic feature of this plateau is the escarpment, which runs along the southwestern boundary of the Reserve (see plate 1). The escarpment marks the edge of the southern highlands, a series of hills in the southern half of the Reserve. From the top of these hills, the highest point of which is Thumb Hill at 986 meters (3235 feet)asl, the escarpment drops precipitously to the rolling prairie below. This is a drop of approximately 96 metres (315 feet) over slopes which reach 60 percent. (See topographical profiles A-A' and B-B'; the location of each is given on the Study Area map).

The escarpment slopes are characterized by a mixture of tertiary gravels, till and variable soil. Several small exposures of bedrock are found along the edge of the escarpment, many pieces of which are scattered across the top of slump lobes. A high percentage (up to 70\%) of the slopes are exposed mineral soil (see plate 2).

The top of the southern highlands have a rolling landscape, broken only by the beginning of a few small gullies and by one major slump feature, which is located at the head of a coulee. These highlands are bedrock controlled topography; essentially a thin veneer of moraine over undulating bedrock (see plate 6).

Thumb Hill is a prominent feature in this region but it is not the highest point in the Alberta prairies. The Cypress Hills are 471 meters (1545 feet) higher in elevation.

In most places the escarpment is a smooth slope but it has been modified by the formation of gullies and small coulees. Slopes along the escarpment are usually in the $30 \%$ to $40 \%$ range, however some areas, particularly along the scarp face of slumps and the more actively eroding sites, have slopes ranging from 40 to 60 percent.

There are numerous slump features along the face of the escarpment. The uppermost layer of the plateau is composed of tertiary gravels and is quite permeable to water movement. The slumps are the result of groundwater coming to the surface at the edge of the escarpment and facilitating mass movements of material at the actively (but slowly) eroding edge.

At the base of the escarpment, in the extreme southwest corner of the Reserve, is a drumlin. It has the classic streamlined shape and is situated just at the edge of the slump features. It was probably formed as part of a prominent ice-thrust feature which lies adjacent to this site, just outside the 

Reserve boundary.

\section{Rolling Edge of Southern Highlands}

The southern highlands descend to the more extensive level plain via a series of rounded, low angled ridges. Along the east side of the highlands these ridges grade into a lightly rolling landscape with low-level hillocks (see plate 4). In the south-east corner of the Reserve this topography continues right up to the high-water shoreline of Little Fish Lake. Along the north side of the highlands these ridges smooth out onto the level plain which covers much of the Reserve.

This area is characterized by morainal blankets and veneers. There may be some bedrock control here but the surface expression is more likely a reflection of the thicker deposits here than are found on the top of the southern highlands.

\section{Little Fish Lake}

The high-water shoreline around the nothwest part of this lake is marked by a near-vertical drop of two meters onto the flat lake bottom, much of which is dry due to low water levels. The entire exposure is composed of till (with many rounded granitic cobbles) and the deep red cobbles characteristic of the tertiary gravels. There are numerous large boulders scattered along the dry shore of the lake.

\section{Plains}

Most of the central and northern part of the Reserve is a level to slightly rolling plain (see plate 3 ). Meso-scale relief is one to two meters, except in the extreme northeast corner, where it reaches five to tem meters. The lowest part of the plain is centred around the outlet channel of Little Fish Lake. From this point, the land rises slowly to the north.

Glaciofluvial deposits dominate the central area of the Reserve. They are generally sandy in nature with a minor gravel component. For the most part, they are located on upland areas but are also found as a veneer on the steeper slopes leading down into the coulee in the northwest corner of the Reserve. On the steeper slopes of this coulee it is designated as a rough broken deposit.

Within the glaciofluvial plain are two interesting features. The first is a series of three sand hills which are located closely together near the northern edge of the southern highlands. They are circular, domed features approximately 50 to 70 meters (164 to 230 feet) across and about nine meters ( 34 feet) high. They are composed almost entirely of sand (apart from a few small gravels in the upper layers), the colour of which ranges from light grey to light yellowish brown. The hill is made of alternating layers of coarse, medium and very fine sand but there is no evidence of cross bedding. These are probably glaciofluvial rather than aeolian deposits. There are also level sites near these hills which are predominately sand deposits with a high gravel content.

The second feature of note are several kames. They are mostly small features, occasionally as much as ten to fifteen metres ( 30 to 50 feet) across and two to three meters (five to ten feet) high. They are composed mainly of gravel and large cobbles. 

Overlying part of this glaciofluvial plain is a large glaciolacustrine deposit. It is found in an east-west band, extending from the eastern boundary of the Reserve north of Little Fish Lake to near the coulee in the northwest corner. It's low relief, slightly hummocky surface is probably the result of postdepositional erosion.

There are four remnant beach ridges on this glaciolacustrine deposit, all of them spaced well apart. Each is three to five meters (10 to 16 feet) high and 500 to 700 meters (1640 to 2300 feet) long (two have been dissected by fluvial erosion). These ridges are low-angled features, with slopes of zero to thirteen percent, and well rounded tops. They are composed predominately of brown to light-grey silt, with some gravel near the surface. All of them are aligned in a northwest-southeast orientation. They are possibly the remnant shorelines of a much larger lake which once covered this part of the Hand Hills (R. Wells, pers. Comm.).

There are several large lacustrine deposits in the centre of the Reserve. These represent ephemeral wetlands which contain standing water during the spring melt season and following periods of heavy rainfall. They are located along the southern edge of the glaciolacustrine deposits, on the glaciofluvial. They receive sediment from numerous ephemeral drainage channels.

\section{Coulees}

There are three large coulees in the Reserve, all in the western half. The southern and northern coulees are similar, with low-angled slopes which are, for the most part, well-vegetated. The central coulee is quite different. It is much larger, follows a more circuitous course and has much steeper slopes (see plates 11 and 12).

This central coulee starts in the approximate center of the Reserve and travels a very sinuous route to the western boundary. At the point where this coulee starts to become incised, it is 70 meters ( 230 feet) across and nine meters (30 feet) deep. Near the western boundary of the Reserve, it has increased in size to 230 meters ( 755 feet) across and 27 meters ( 89 feet) deep.

Just outside the western boundary of the Reserve, the coulees break through the edge of the escarpment and their size changes abruptly. A mere 950 meters $(0.6$ miles) from its widest and deepest point, the coulee has shrunk to 65 meters ( 213 feet) across and 10 meters ( 32 feet) deep. Another 1.5 kilometres (one mile) further west and this coulee is nothing more than a shallow gully.

The overall local relief of the Reserve is 121 meters ( 397 feet). The southern highlands rise an average of 76 meters ( 250 feet) above the surrounding plain of the Reserve. 



\section{Topographic profile A-A'}

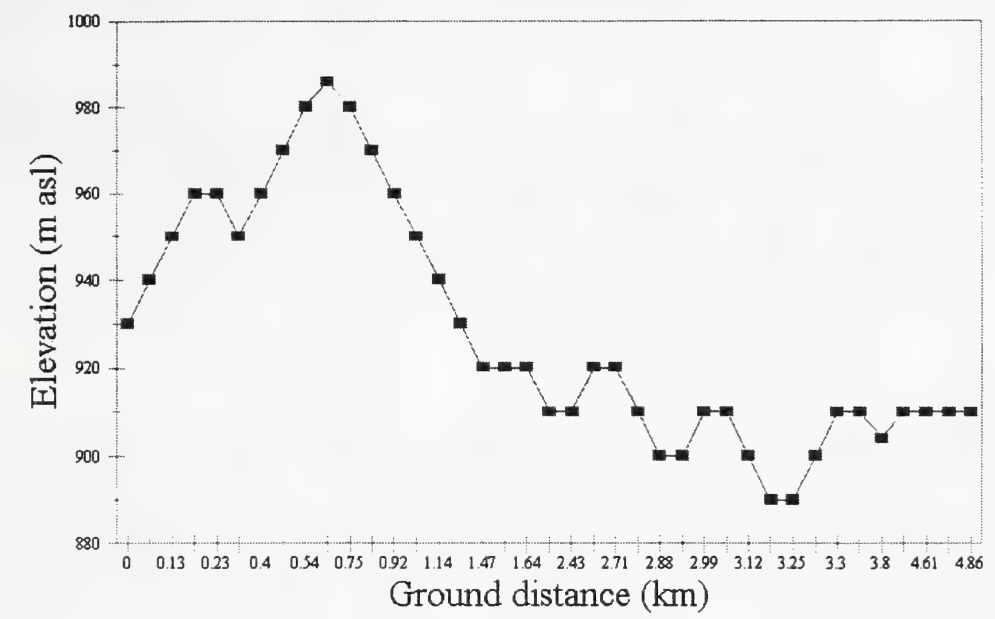

\section{Topographical profile B-B'}

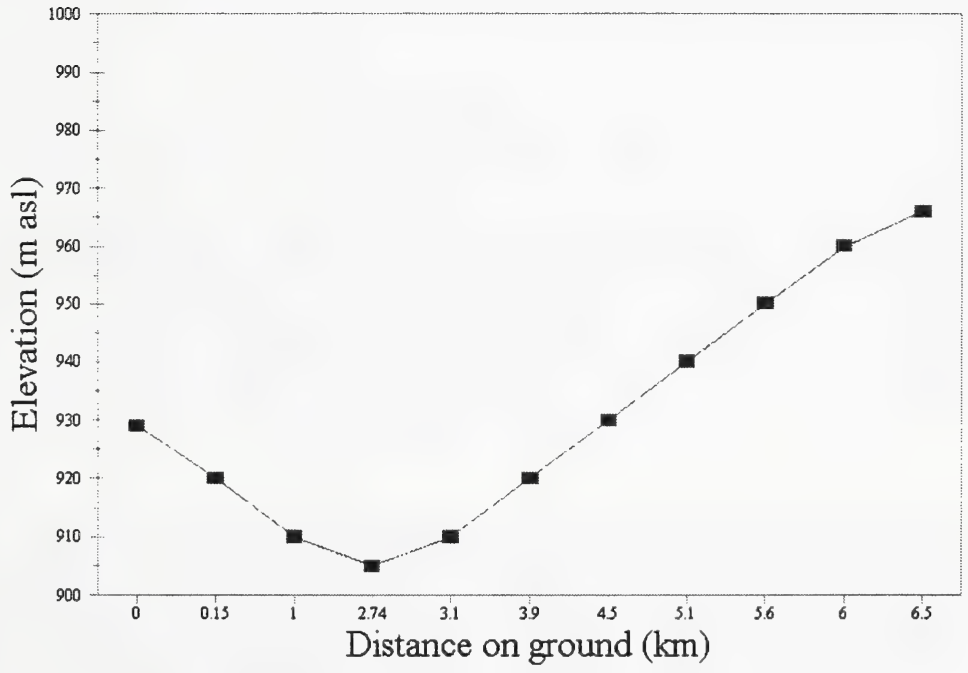

Figure 1: Topographical profiles of the Reserve

A-A' - north-south profile along western edge of Reserve.

B-B' - north-south profile along eastern edge of Reserve. 



\subsection{Soils}

Sixteen soil types occur in the Reserve, representing four great groups: Chernozemic, Regosolic, Gleysolic and Solonetzic soils. The location of these soil types are mapped on the Ecological Land Classification map.

\section{Southern Highlands}

The soils of the southern highlands are almost exclusively Dark Brown Chernozems, with a minor component of Dark Brown Solodized Solonetz, mainly on the lower northern slopes. The Chernozems have developed on morainal materials and have a somewhat gravelly silt and clay loam texture overlying clay loam. The texture is fairly uniform across the Highlands, as is the drainage, which is good to moderate.

\section{Escarpment}

The soil along the upper slopes of the escarpment is Gleyed Dark Brown Chernozems. The top of the plateau covered by a layer of tertiary gravels, which is highly conducive to subsurface water movement. This is why soils at this site are gleyed while the same soil type only a few meters away, on top of the plateau, is not. Texture is similar to that found on top of the highlands; gravelly loams but with a higher clay content. These soils are well drained.

Most of the escarpment is classified as Orthic Regosols, either because the slopes are composed mainly of exposed gravel or because normal soil horizon development is impeded by downslope movement.

\section{Plains}

The plains area of the Reserve is a complex mix of soil types.

Solonetzic soils are common on a variety of parent materials. Solodized Solonetzic soils are found on morainal deposits, usually in association with Dark Brown Chernozems. Solonetzic soils are often found in complex associations with other soil types (Alberta Agriculture 1981). Old blowouts are common but they are mostly vegetated and there is not much exposed mineral soil. Textures are silts and clays over clays. Occasionally textures are much coarser, due to the numerous sand deposits found around the base of the southern highlands. Drainage is usually quite good.

Solonetzic soils are also common on glaciofluvial materials along the Little Fish Lake drainage channel and in nearby low areas. This location represents the major subsurface water collection area in the Reserve. Local discharge of saline groundwater, such as occurs in this part of the Reserve, leads to the development of Solonetzic soils (Toogood and Cairns 1973). Blowouts are very common, as are large expanses of mineral soil. These are coarse textured soils, generally silts and sands over gravelly sand or, occasionally, silty clay. These are well drained to rapidly drained areas.

Solods are also found on the glaciofluvial deposits, mainly in the area just north of Little Fish Lake. These moderately textured, well drained soils are usually associated with Dark Brown Chernozems, 

occasionally subordinate to them.

The glaciolacustrine plain in the north half of the Reserve is characterized by an association of Orthic Black Chernozems and Dark Brown Solods, with the former usually dominant. Blowouts are numerous but for the most part old and revegetated. These are well drained soils with loamy textures.

All of the drainage channels in the north half of the Reserve have Orthic Black Chernozems. These are moderately well drained, fine textured soils, composed mainly of loams and clay loams. In the southern half of the Reserve, the drainage channels are not as deep or as well defined, and consist of Solonetzic soils.

The soil of depressional areas in the central plain varies according to the length of time the subsurface remains water saturated. The driest of these depressional areas has fine textured Dark Brown Chernozems which are imperfectly drained. Slightly wetter areas have Gleyed Black Chernozems, which are also fine textured and imperfectly drained. Areas with standing water for most, if not all, of the summer have Luvic Gleysols. These are finely textured soils with poor drainage.

The northern-most section of the Reserve is dominated by Orthic Black Chernozems. This rich, deep soil consists of silty clays and clays which are moderately well drained.

\section{Coulees}

The walls of the three coulees have all been classified as Orthic Regosols, due to either their lack of horizon development or the mixing of horizons caused by slopewash. They are very fine-textured soils, generally clays over clay loams, and usually imperfectly drained.

The soils at the bottom of the coulees varies according to the shape of the coulee. In wide bottomed coulees the soil is usually Luvic Gleysols; fine textured and very poorly drained. As the coulee bottom narrows, slopewash becomes more prominent and the soil is classed as either a Gleyed Regosol or Orthic Regosol, depending on the amount of subsurface water. In either case, both soils are very fine textured and are imperfectly to poorly drained.

\subsection{Hydrology}

There is little surface water in the Reserve. The largest waterbody is the marsh, located in the drainage channel of Little Fish Lake (see plate 14). It is actually a reservoir since the water is kept in this basin by a small earthen dam at its eastern end. This dam was built next to the lake shoreline in the 1960's by Ducks Unlimited to maintain high water levels in the lake. Drainage from the western end is prevented by a build-up of soil along the main truck track which passes next to the marsh.

The size of the reservoir-marsh changes within and between years, depending on the amount of 

winter snow and subsequent summer precipitation levels. The size of this waterbody by mid-summer over the past several years has ranged from that of a full basin to an empty and dry one. The size of the basin is approximately 550 metres long and 60 meters wide (1800 feet by 196 feet)

It is a shallow feature (probably less than one meter in depth) whose natural shoreline is a gentle slope. A dugout has been constructed in the middle of the marsh with the result that the shoreline is steep and poorly vegetated.

There are eight dugouts in the Reserve; three in the bottom of coulees, four in ephemeral drainage channels on the grasslands and the one in the reservoir-marsh. They vary in size from $20 \times 25$ meters to $20 \times 55$ meters (from $65 \times 82$ feet to $65 \times 180$ feet). With one exception, they are steep sided waterbodies with a raised edge and little or no aquatic vegetation. The one exception, in the southeast corner of the Reserve, has almost no raised edge and is turning into a marsh wetland.

There are several ephemeral sloughs in the Reserve. The large ones, which usually contain little or no water after the spring melt, are part of the drainage system in the centre of the Reserve. The few sloughs which hold water for most or all of the summer are small in size and usually located in the coulee bottoms. The one exception is located in the extreme southeast corner.

In the bottom of the large coulee, adjacent to the west boundary of the Reserve, is a series of adjoining beaver ponds. They are small, semi-permanent features located along the drainage channel of Little Fish Lake. Some of them have developed marsh vegetation, including cattails. The coulee in the northwest corner of the Reserve has a few similar features though they are much smaller in size.

Drainage patterns throughout the Reserve are quite simple. (See the Study Area map for location of the drainage channels). Water along the escarpment flows south and west, immediately out of the Reserve. Water on the southern highlands flows either east into the Little Fish Lake basin or north, into the reservoir-marsh. Water in the north half of the Reserve flows along a series of shallow drainage channels into either the Little Fish Lake basin or the area immediately surrounding the reservoir-marsh. Water collected in the reservoir-marsh flows west into the large coulee and then into Willow Creek, several kilometers west of the Reserve. Water which reaches the Little Fish Lake basin would presumably remain there since this basin has so little water in it.

With the exception of the spring melt season or periods with heavy summer precipitation, all drainage is subsurface. The surface expression of the drainage patterns is clearly marked by numerous drainage channels arranged in a typical dendritic pattern. These channels are generally shallow and only three to four meters wide. They are also evident due to their vegetation communities, which are noticeably different from the surrounding uplands. 



\subsection{Biotic Features}

\subsection{Vegetation}

The vegetation of the Reserve is an expression of many environmental factors, including climate, surficial deposits, soils and grazing intensity. The Reserve contains a diversity of vegetation including grassland communities, coulee slopes with a patchwork of different community types, meadows, shrublands, aspen copses, and wetlands. (Note: the vegetation communities are mapped on the Ecological Land Classification map).

Fescue grassland typical of the Northern Fescue Subregion (Achuff 1994) is the modal, and the most extensive, vegetation type in the Reserve, where chernozemic soils are present. A variety of mixed grassland communities are also present, each having a different proportion of rough fescue, depending on edaphic factors and the level of grazing. The most common graminoid species in the Reserve are Rough fescue, Western porcupine grass and Hooker's oat grass. Forb diversity is high in some areas, and includes such species as Northern bedstraw, Harebell, Wild vetch and Shining arnica. Three rare plant species, as well as four disjunct cordilleran and one disjunct prairie species, are found in the Reserve grasslands.

Vegetation more typical of the Mixedgrass Subregion (Achuff 1994) occurs on very dry upland sites. Mixed grassland communities are also found in other parts of the Reserve where the normal climax community is fescue grassland. However, in response to grazing, non-modal community types develop which have species more characteristic of drier ecoregions. Typical graminoid species in mixed grassland communities include Blue grama, Needle-and-thread, June grass and dry-land sedges.

The variety of gradients and aspects found in coulees has led to the development of a variety of vegetation community types, including forb-grass communities, treed slopes, and shrub-dominated areas. South-facing slopes are characterized by species such as Blue grama, Creeping juniper and forbs, which are adapted to dry conditions. Where grasslands occur on moister, north-facing slopes, Rough fescue is the dominant grass species. In the larger coulees, the north-facing slopes may be colonized by aspen woodland, often rimmed by tall shrub communities dominated by Bebb's willow and Choke cherry. Downslope areas in the coulees receive runoff and nutrients from the upper slopes, and usually support shrub communities dominated by Buckbrush, Choke cherry, Saskatoon and Rose.

Two upland communities in the Reserve also have significant shrub cover. Scattered Buckbrush and Rose tend to grow in shallow swales within ephemeral drainage channels while patches of Silverberry occupy local areas underlain by coarse-textured glacial stream deposits.

Aspen is also found in isolated clones in the northeast part of the Reserve (section 25). These welldefined copses are generally circular in outline, indicative of continuous growth outwards from a central point of origin. They are slowly expanding in size and have a consistent pattern of dead stems 

in the centre with young aspen growth around the perimeter. Awnless brome, a non-native invader species, has proliferated in many of these aspen clones.

There is also a single aspen clone located on the highlands in the southern part of the Reserve. It is an isolated feature and considerably younger than the clones in section 25 .

There are a few wet meadows in the Reserve, occurring in either small depressions in the upland, or occasionally in association with drainage channels. These areas are flooded for part of the year, and are characterized by a variety of hydrophytic plant species.

Moist meadows occur within ephemeral drainage channels and are characterized by high forb diversity. In wet years these communities have spectacular flower blooms, a feature found only in relatively undisturbed grasslands.

The vegetation of the Reserve is constantly changing, adjusting to a wide variety of environmental influences. This is evident in different sets of air photos taken of the Reserve over the past two decades. For example, in 1974, there was a large continuous patch of Silverberry (Elaeagnus commutata) near the corral in the centre of the Reserve. By 1981 this stand of shrubs had started to break apart into several smaller patches. By 1996, this stand had degenerated into several distinct and widely separated patches. The entire Reserve appeared to have had a higher shrub cover in 1974 than it does in 1996.

These airphotos also show the widely fluctuating nature of surface water in the area. In some years, the wetlands were numerous and extensive; in other years, they were all completely dry. The same is true of the shoreline of Little Fish Lake (note: it is not believed that the entire surface of Little Fish Lake has ever been completely dry).

The woodlands have also changed over time. Airphotos taken in the 1940's show the aspen copses in section 25 to be very small, covering less than one percent of the section. By the mid-1980's, they had increased in size to the point where they covered five percent of this section.

There are twenty-one vegetation community types within the Reserve. Many local environmental factors, such as variations in drainage and soil type, as well as disturbance factors such as grazing pressure, control the composition of plant species and, thus, community type. Given below is a list of all community types, followed by a detailed discussion of each one (in the same order as in the list). For more detailed environmental and floristic information related to each vegetation community type, see Appendix I. The location of these communities is provided on the Ecological Land Classification map. 



\section{Fescue Grassland}

Rough Fescue

\section{Mixed Grassland}

Rough Fescue - Western Porcupine grass

Rough Fescue - Green Needle Grass - Forbs

Rough Fescue - June Grass - Juniper - Forbs

Western Porcupine Grass - Rough Fescue - Forbs

June Grass - Sedge - Sage - Selaginella

Needle and Thread Grass - Sedge - Selaginella

Gumweed - Bluegrass - Foxtail Barley

\section{Shrubbery}

Buckbrush - Rough Fescue

Rose - Rough Fescue - Forb

Silverberry - Rough Fescue - Hooker's Oat Grass

Salix/Saskatoon - Rough Fescue/Bluegrass

Buffaloberry - Rough Fescue

\section{Woodlands}

Aspen - Buckbrush - Forb - Wheat Grass

Aspen - Awnless Brome

Poplar - Buckbrush - Wheat Grass

\section{Ephemeral Riparian Meadows}

Mixed-Grass - Forb

Agrostis - Carex - Forb

\section{Wetlands}

Bluegrass - Hair Grass - Cinquefoil

Sedge - Hair Grass

Sedge - Wire Rush

Marsh community

\section{Disturbance communities}

Truck tracks

Dirt road

Reclaimed well site

Dugout spoil piles 



\section{FESCUE GRASSLAND}

\section{Rough Fescue community type}

This community type represents a climax fescue association. It occurs where ecological moisture regimes are generally mesic, slightly moister than in areas where western porcupine grass is codominant (see Rough fescue - Western porcupine grass community below). No recent grazing has occurred on sites occupied by this community. The dominant species, rough fescue, grows in thick tussocks, and most associated species occur between tussocks. In some areas, rough fescue can grow to the virtual exclusion of other species. Characteristic associated species, which are often of low cover, include western porcupine grass, Hooker's oat grass, northern bedstraw, wild vetch, field mouse-ear chickweed and harebell (see plates 5 and 6).

Key and indicator species:

\section{Scientific name}

Graminoids: Dominant species:

Festuca scabrella

Secondary species:

Stipa curtiseta

Helictotrichon hookeri

Agropyron dasystachyum

Forbs:

\author{
Vicia americana \\ Galium boreale \\ Arnica fulgens \\ Oxytropis sericea \\ Cerastium arvense \\ Campanula rotundifolia
}

Common name

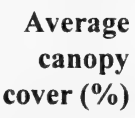

Rough fescue

Western porcupine grass

Hooker's oat grass

Western wheat grass

Wild vetch

Northern bedstraw

Shining arnica

Early yellow locoweed

Field mouse-ear chickweed

Harebell
Range classification: Primary

Sites:10, 16, 17, 31, R10, R11, R19
Range condition: excellent

Successional status: climax 



\section{MIXED GRASSLANDS}

\section{Rough Fescue - Western Porcupine grass community type}

Plant species diversity is greater in this community than in the previous one. However, Rough fescue cover is lower, with proportionately higher cover values of western porcupine grass. This type represents the climax community on slightly drier sites than those dominated by only rough fescue. Moisture regimes at these sites are mesic to submesic (see plate 3).

Light grazing of Rough fescue grasslands, along with the somewhat drier soil conditions, may also lead to the development of this community type. Moss and Campbell (1947) examined the distinction between undisturbed fescue grasslands, and those affected by grazing. They found that with light grazing on sites with good moisture conditions, rough fescue cover decreases, to be succeeded by species such as western porcupine grass, june grass and wheat grasses. In addition, as a result of the thinner thatch or litter layer, the diversity of forb species increases with light grazing (Moss and Campbell 1947, Johnston 1961).

Mowing affects fescue grasslands to a lesser degree than grazing (Wallis 1990). With mowing, the rough fescue tussocks become smaller in size (Moss and Campbell 1947), giving advantage to the associated species, especially forbs (Looman 1969). However, rough fescue remains dominant. Also, since the effects of mowing are applied equally over the entire area, a fairly uniform distribution of fescue cover still occurs. These observations were noted at one of the sites (R20), a site which had apparently been mowed the previous year. Comparison with an adjacent unmowed field (site R19) showed a greater number of species at site R20, although fescue cover values were still fairly high. 

Key and indicator species:

Scientific name

Common name

Average

canopy

cover $(\%)$

Graminoids: Dominant:

Festuca scabrella

Stipa curtiseta

Secondary species:

Helictotrichon hookeri

Poa interior

Koeleria macrantha

Thermopsis rhombifolia

Forbs:

Anemone patens

Selaginella densa

Vicia americana

Cerastium arvense

Oxytropis sericea

Castilleja lutescens

Arnica fulgens

Astragalus missouriensis

Sisyrinchium montanum

Range classification: Primary

Sites: 1,4,5, 6, R09, R13, R14, R15, R20
Rough fescue

Western porcupine grass

15

Hooker's oat grass

5

Interior bluegrass

June grass

$<1$

1

Golden bean

Prairie crocus

Selaginella

Wild vetch

Field mouse-ear chickweed

Early yellow locoweed

Stiff yellow paintbrush

Shining arnica

Missouri milk vetch

Blue-eyed grass

Range condition: good to excellent

Successional status: climax 



\section{Rough Fescue - Green Needle Grass - Forbs community type}

This community occurs on steep south- and west-facing slopes along the escarpment, and has a submesic to subxeric moisture regime. It is similar to the Rough fescue-June grass-Juniper-Forb community (see below), but is drier, and there are no shrubs. This community type is also characterized by a diversity of species tolerant of dry moisture regimes. These include prickly-pear, ground-plum, narrow-leaved puccoon and the short grass blue grama. Sand grass also occurs here.

Key and indicator species:

Scientific name

Graminoids: Dominant:

Festuca scabrella

Stipa viridula

Secondary species:

Koeleria macrantha

Stipa curtiseta

Agropyron dasystachyum

Calamovilfa longifolia

Bouteloua gracilis

Forbs:

Artemisia ludoviciana
Thermopsis rhombifolia
Geum triflorum
Comandra umbellata
Senecio canus
Opuntia polyacantha
Heterotheca villosa
Lithospermum incisum
Astragalus crassicarpus
Astragalus tenellus

Range classification: Secondary

Sites: \#12
Common name

\section{Average \\ canopy \\ cover $(\%)$}

Rough fescue $\quad 35$

Green needle grass 20

June grass 5

Western porcupine grass 5

Northern wheat grass 2

Sand grass 5

Blue grama 1

Prairie sagewort $\quad 8$

Golden bean 1

Three-flowered avens 2

Bastard toadflax 1

Prairie groundsel 1

Prickly-pear 1

Golden aster 2

Narrow-leaved puccoon 1

Ground-plum 1

Loose-flowered milk vetch $\quad 1$

Range condition: good

Successional status: edaphic climax 



\section{Rough Fescue - June Grass - Juniper - Forbs community type}

This community occurs on steep south and southwest-facing coulee slopes, where the moisture regime is subxeric. A low shrub, creeping juniper, is prominent. Other shrub species include prairie rose and Canada buffaloberry. This community type is characterized by a high diversity of forb species, many of which are characteristic of dry areas. Yellow umbrella-plant, prairie onion and scarlet butterflyweed are examples of species tolerant of dry soil conditions (see plate 12).

Key and indicator species:

\section{Scientific name}

Graminoids: Dominant:

Festuca scabrella

Koeleria macrantha

Secondary species:

Stipa curtiseta

Stipa viridula

Agropyron dasystachyum

Forbs:
Common name

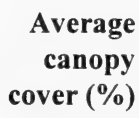

Average

canopy

$\operatorname{cover}(\%)$

Rough fescue 20

June grass

Western porcupine grass 5

Green needle grass 5

Northern wheat grass 5

Golden bean 5

Yellow umbrella-plant 5

Tufted fleabane 5

Alpine hedysarum 5

Bastard toadflax 1

Wild blue flax 1

Prairie onion 1

Gaillardia 1

Scarlet butterflyweed 1

Long-fruited wild parsley 1

Missouri goldenrod

Creeping juniper $\quad 15$

Canada buffaloberry 2

Prairie rose 2

Range condition: good

Successional status: edaphic climax 



\section{Western Porcupine Grass - Rough Fescue - Forbs community type}

This is a fescue grassland community modified by the effects of moderate grazing. Rough fescue is a decreaser (Moss and Campbell 1947, Wroe et al 1988) so cover values are reduced in response to grazing. As grazing levels increase further, rough fescue becomes patchy, persisting at the microsite level only on the moist areas. Species favoured by grazing include prairie selaginella and pasture sagewort (Alberta Agriculture 1996). Species composition of this community type is summarized below (see plate 4).

Key and indicator species:

Scientific name

Graminoids: Dominant:

Festuca scabrella

Stipa curtiseta

Secondary species:

Helictotrichon hookeri
Carex obtusata
Carex stenophylla
Koeleria macrantha

Forbs:

Selaginella densa

Artemisia frigida

Anemone patens

Antennaria aprica

Thermopsis rhombifolia

Taraxacum officinale

Vicia americana
Common name

Average canopy cover

(\%)

Rough fescue 11

$\begin{array}{ll}\text { Western porcupine grass } & 17\end{array}$

Hooker's oat grass 1

Blunt sedge 1

Low sedge 7

June grass 5

Prairie selaginella $\quad 17$

Pasture sagewort 5

Prairie crocus 4

Low everlasting 4

Golden bean 2

Dandelion

Wild vetch $\quad<1$

Range condition: good to fair

Successional status: seral

Sites: 7, R01, R12 



\section{June Grass - Sedge - Sagewort - Selaginella community type}

This community type has likely developed in response to long-term heavy grazing (see plate 7). On the most heavily grazed sites, rough fescue is almost eliminated. June grass and two dryland sedge species, blunt sedge and low sedge, become abundant. Dryland sedges such as low sedge do well under conditions of heavy grazing (Alberta Agriculture 1996). June grass tends to be more abundant on the drier grazed sites, and increaser forb species such as pasture sagewort and prairie selaginella are also indicative of grazing pressure. The presence of the short grass species blue grama, though in low cover, is also significant. Blue grama is typical of the climax modal grassland vegetation in the drier Mixedgrass Subregion further south, where light brown soils dominate (Coupland 1950). This grass species spreads into the fescue grasslands where there is heavy grazing (Moss and Campbell 1947).

Based on the presence of several forb and grass species characteristic of fescue grasslands, and considering the modal landscape position and moisture regime, the climax community on sites occupied by this type is predicted to be a rough fescue - western porcupine grass type. That is, without the effects of heavy grazing, these areas would be occupied by a rough fescue - western porcupine community type. 

Key and indicator species:

Scientific name

Common name

Average

canopy

cover $(\%)$

Graminoids: Dominant:

Carex stenophylla

Carex obtusata

Koeleria macrantha

Secondary species:

Stipa curtiseta

Poa interior

Festuca scabrella

Bouteloua gracilis

Forbs: Dominant:

$$
\text { Artemisia frigida }
$$
Selaginella densa

Secondary species:

Anemone patens

Antennaria aprica

Erigeron caespitosum

Cerastium arvense

Achillea millefolium

Heterotheca villosa

Allium textile

Geum triflorum
Low sedge

Blunt sedge

June grass

Western porcupine grass $\quad 5$

Interior bluegrass 7

Rough fescue 2

Blue grama

Pasture sagewort $\quad 10$

Prairie selaginella 11

Prairie crocus 4

Low everlasting 3

Tufted fleabane 2

Field mouse-ear chickweed 2

Yarrow

Golden aster

Prairie onion

Three-flowered avens

Range condition: fair to poor

Successional status: seral

Sites: 8, 9, R04, R05 



\section{Needle and Thread - Sedge - Selaginella community type}

The dominant species of this community type are typical of the Mixed grass Subregion. A needle and thread- blue grama type is the characteristic climax association in the light brown soil zone. which does not include the study area. However, it does occur in the driest parts of the dark brown soil zone, such as very dry upper slopes and tops of knolls (Coupland 1950). In the Reserve, it is found on top of the highlands in the southwest corner (see plate 6). The community type is similar in plant species composition to the predicted climax, Needle and thread - Blue grama. The predominance of needle-and-thread instead of porcupine grass, which is found throughout most of the upland grasslands in the Reserve, is likely a response to the dry soil conditions.

Key and indicator species:

Scientific name

Graminoids: Dominant:

Stipa comata

Carex obtusata

Secondary species:

Bouteloua gracilis

Koeleria macrantha

Forbs: Dominant:

Selaginella densa

Secondary species:

Anemone patens

Erigeron caespitosus

Artemisia frigida

Thermopsis rhombifolia

Comandra umbellata

Range classification: Primary

Sites: R07, R08
Common name

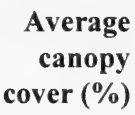

Needle-and-thread

10

Blunt sedge

Blue grama

June grass

Prairie selaginella

Prairie crocus

Tufted fleabane

Pasture sagewort

Golden bean

Pale comandra

Range condition: fair

Successional status: edaphic climax 



\section{Gumweed - Bluegrass - Foxtail Barley community type}

Solonetzic soils occur near the drainage from Little Fish Lake. These fine-textured soils alternately swell and shrink with changing moisture conditions, causing root disturbance which only some species can tolerate (North 1976). Furthermore, root and water penetration below the surface of this type of saline soils are restricted by an impermeable layer of dry hardpan which forms in a columnar structure (Peters 1981). Gumweed, saline plantain and foxtail barley are tolerant of relatively high salinity and as such, are the dominant plant species in most areas which have solonetzic soils (see plate 9)..

Key and indicator species:

Scientific name

Common name

Average

canopy cover

Graminoids: Dominant:

Hordeum jubatum

Poa cusickii

Secondary species:

Agropyron smithii

Distichlis stricta

Foxtail barley

Early bluegrass

Western wheat grass 5

Salt grass

Forbs: Dominant:

Grindelia squarrosa

Gumweed

Secondary species:

Plantago eriopoda

Achillea millefolium

Saline plantain

2

Common yarrow 2

Potentilla anserina

Silverweed

2

Artemisia frigida

Erigeron caespitosus

Pasture sagewort

Tufted fleabane

Range classification: Primary

Sites: \#14
Range condition: poor to fair

Successional status: edaphic climax 



\section{SHRUBBERY}

\section{Buckbrush - Rough Fescue community type}

This community type is found in shallow ephemeral drainage channels with a mesic ecological moisture regime. The site is dominated by buckbrush, although common wild rose is also present. Some awnless brome has invaded the site, but rough fescue is the dominant graminoid (see plates 10 and 12).

Key and indicator species:

Scientific name

Common name

Average

canopy

cover $(\%)$

Graminoids: Dominant:

Festuca scabrella Secondary species:

Bromus inermis

Forbs:

Achillea millefolium Artemisia ludoviciana

Cerastium arvense

Shrubs: Dominant:

Symphoricarpos occidentale Secondary species:

Rosa woodsii

Range classification: Primary

Sites: \#33
Rough fescue

Awnless brome 5

Common yarrow Prairie sagewort Field mouse-ear chickweed

Buckbrush

Common wild rose
Range condition: fair

Successional status: seral 


\section{Rose - Rough Fescue - Forb community type}

This community is found most often along the escarpment slopes but also occasionally on lower north- and west-facing coulee slopes which have a mesic to submesic moisture regime. A wide diversity of both forbs and shrubs characterizes these shrublands. Cover of common wild rose is greater as one moves downslope, and choke cherry and northern gooseberry also grow primarily in lower slope areas. Creeping juniper and Canada buffaloberry, on the other hand, occur in drier, usually upper slope, areas of the coulees. Alpine hedysarum, a forb species characteristic of moist meadows and grassy slopes, constitutes a substantial portion of the forb layer.

Key and indicator species:

Scientific name

Common name

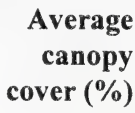

Graminoid Dominant:

Festuca scabrella

Secondary species:

Stipa viridula

Helictotrichon hookeri

Koeleria macrantha

Forbs:

Hedysarum alpinum
Geum triflorum
Galium boreale
Thermopsis rhombifolia
Fragaria virginiana
Heuchera richardsonii
Vicia americana
Castilleja lutescens
Penstemon procerus
Senecio canus
Gaillardia aristata
Potentilla arguta

Shrubs: Dominant:

Rosa woodsii

Secondary species:

Symphoricarpos occidentale

Amelanchier alnifolia

Juniperus horizontale
Rough fescue

Green needle grass

Hooker's oat grass

June grass

\section{3}

Alpine hedysarum

Three-flowered avens

Northern bedstraw

Golden bean

Wild strawberry

Richardson's alumroot

Wild vetch

Stiff yellow paintbrush

Slender blue beardtongue

Prairie groundsel

Gaillardia

White cinquefoil

Common wild rose

14

Buckbrush

6

Saskatoon

Creeping juniper
Range classification: Secondary

Sites: 11, 13 (coulee slopes)
Range condition: good

Successional status: climax 



\section{Silverberry - Rough Fescue - Hooker's Oat Grass community type}

This community grows on coarse-textured soils, both on upland areas and along some of the larger ephemeral drainage channels. Silverberry is by far the predominant shrub. Species composition of the understory forbs and grasses is similar to the surrounding upland fescue grasslands, but with lower cover values.

Key and indicator species:

\section{Scientific name}

Graminoids: Dominant:

Festuca scabrella Helictotrichon hookeri Secondary species:

Koeleria macrantha

Forbs:

Galium boreale
Oxytropis sericea
Geum triflorum
Achillea millefolium
Astragalus missouriensis
Sisyrinchium montanum

Shrubs:

Dominant:

Elaeagnus commutata

Secondary species:

Rosa woodsii

Range classification: Secondary

Sites: R16

\section{Common name}

Rough fescue

Hooker's oat grass

June grass

10

Northern bedstraw

Early yellow locoweed

Three-flowered avens

Yarrow

Missouri milk vetch

Blue-eyed grass

Average

canopy cover

(\%)

30

20

Silverberry

Common wild rose

Range condition: good

Successional status: edaphic climax 



\section{Salix/Saskatoon - Rough Fescue/Bluegrass}

This community type occurs on north-facing slopes of coulees, and is characterized by a fairly dense cover of shrubs, primarily willow and saskatoon. Other shrubs present, though in low cover, include buckbrush, Canada buffaloberry, silverberry, northern gooseberry, choke cherry and common wild rose. There was a also high diversity of forb species, many of which are also found in the moister areas of adjacent fescue grasslands. The presence of Sprengel's sedge is indicative of the favourable moisture regime, since this species usually grows on moist alluvial areas. Smooth brome had invaded the coulee site investigated, and cover of brome was greater in the moister lower slope areas closer to the coulee bottom (see plate 12).

Key and indicator species:

\section{Scientific name}

Graminoid Dominant:

Festuca scabrella

Poa canbyi

Secondary species:

Bromus inermis

Agropyron dasystachyum

Carex sprengelii

Forbs:

Shrubs:

Dominant:

Salix bebbiana

Amelanchier alnifolia

Secondary species:

Hedysarum alpinum

Geum triflorum

Galium boreale

Thermopsis rhombifolia

Fragaria virginiana

Heuchera richardsonii

Vicia americana

Castilleja lutescens

Taraxacum officinale

Thalictrum venulosum
Common name

Rough fescue

Canby bluegrass

Smooth brome

Northern wheat grass

Sprengel's sedge

Alpine hedysarum

Three-flowered avens

Northern bedstraw

Golden bean

Wild strawberry

Richardson's alumroot

Wild vetch

Stiff yellow paintbrush

Common dandelion

Veiny meadow rue

\section{Average \\ canopy \\ cover $(\%)$}

Symphoricarpos occidentale

Rosa woodsii

Shepherdia canadensis

Elaeagnus commutata

Prunus virginiana

Ribes oxyacanthoides

Range classification: Secondary

Range condition: good

Sites: \#19, 35

Successional status: climax

Beaked willow

Saskatoon

Buckbrush

Common wild rose

Canada buffaloberry

Silverberry

Choke cherry

Northern gooseberry

\section{(}

\section{(20}

(1)

(n)

(n)

(n)





\section{Buffaloberry - Rough Fescue community type}

This community occurs on coulee slopes with a generally northern aspect, i.e from east through to a west facing slopes. It represents an intermediary community in the coulees. It is found on moister sites than is the Rough fescue-June grass-Juniper-Forb community, which occurs on the dry south facing slopes. However, it persists on drier sites than the tall mixed shrubbery of the Salix/Saskatoon-Rough fescue/Bluegrass community (see plate 12).

The shrub cover is generally scattered and sparse, spread out over the coulee slopes from rim almost to the coulee bottom. In favourable sites, such as on slump benches, the shrubs form continuous stands where forb cover is higher but graminoid cover is lower.

There is a high degree of variability in this community, both in terms of location and species composition. This is due to variation in the coulee slopes, which affects both the degree of solar insolation and the exposure to wind.

Key and indicator species:

\section{Scientific name}

Common name

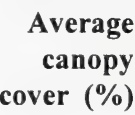

Shrubs

Dominant:

Shepherdia canadensis

Elaeagnus commutata

Symphoricarpos occidentale

Amelanchier alnifolia

Secondary species:

Salix bebbiana

Ribes oxyacanthoides

Forbs

Vicia americana

Galium boreale

Artemisia ludoviciana

Potentilla arguta

Graminoid Dominant:

Festuca scabrella

Stipa viridula

Secondary species:

Poa cusickii

Stipa curtiseta
Canada Buffaloberry

Silverberry

20

Buckbrush

Saskatoon

Beaked willow

Northern gooseberry

Wild vetch

Northern bedstraw

Prairie sagewort

White cinquefoil

Rough fescue 30

Green needle grass
Early bluegrass

Western porcupine grass

Range classification: Secondary

Range condition: good

Sites: 18

Successional status: edaphic climax 


\section{WOODLANDS}

\section{Aspen - Buckbrush - Forb - Wheat grass community type}

This community type is found on steep north-facing coulee slopes, and also on a more shallow northfacing slope in the uplands. Some seepage is likely present at certain times of the year. The forb layer at the coulee site, which had experienced moderate grazing, was dominated by common nettle, a species that often occurs on moist disturbed areas. Other characteristic forb species, though found in low cover, were star-flowered Solomon's seal and field mouse-ear chickweed. Invader species, including weeds such as Canada thistle and common dandelion, and the introduced grass species, awnless brome, were present at these moist sites. Compared to the coulee site, vigour of the aspen at the upland site was poorer. There were many standing dead trees in the centre of the upland copse (see plate 11).

Key and indicator species:

Scientific name

Common name

Average

canopy

cover $(\%)$

Trees Dominant:

Populus tremuloides

Aspen poplar

Shrubs Dominant:

Symphoricarpos occidentale

Rosa woodsii

Secondary species:

Salix bebbiana

Prunus virginiana

Rubus idaeus

Ribes oxyacanthoides

Forbs Urtica dioica

Vicia americana

Galium boreale

Taraxacum officinale

Smilacina stellata

Lathyrus ochroleucus

Cerastium arvense

Artemisia ludoviciana

Cirsium arvense

Graminoid Dominant:

Agropyron trachycaulum

Secondary species:

Bromus inermis
Buckbrush 22

Common wild rose $\quad 12$

Beaked willow 3

Choke cherry 4

Wild raspberry 3

Northern gooseberry 4

Common nettle $\quad 12$

Wild vetch 4

Northern bedstraw 2

Common dandelion 4

Star-flowered Solomon's seal 3

Cream-coloured vetchling 1

Field mouse-ear chickweed 1

Prairie sagewort 1

Canada thistle 1

Slender wheat grass $\quad 25$

Awnless brome
Range classification: Secondary

Sites: \#19, 32
Range condition: fair

Successional status: climax 



\section{Aspen - Awnless Brome community type}

This community type is found in the aspen clones in the northeast part of the Reserve (i.e. section 25). These aspen clones are common only in this part of the Reserve, and their presence is likely attributable to greater soil moisture. The individual aspen clones are slowly spreading outward. However, the trees in the central part of most clones show poor vigour and many are dying, thus creating an open canopy (see plates 5 and 9 ).

In this community type, the understory is dominated by the introduced invader species awnless brome, which has displaced other species. Several weedy or introduced forb species are also present in this community, including Canada thistle, bluebur and common dandelion. The nearby dirt road, which runs along the west and south sides of section 25 , is lined with awnless brome and other weedy species, and likely serves as a seed source for invasion into the aspen copses. The cover of awnless brome may vary between aspen copses, as not all were visited. In addition, fireweed is more common in some aspen clones than others.

Key and indicator species:

Scientific name

Common name

Average

canopy

cover $(\%)$

Trees

Populus tremuloides

Shrubs

Symphoricarpos occidentale Ribes oxyacanthoides

Forbs

Galium boreale

Cirsium arvense

Taraxacum officinale

Smilacina stellata

Vicia americana

Thalictrum venulosum

Lappula squarrosa

Epilobium angustifolium

Graminoids Bromus inermis

Range classification: Secondary

Sites: \#22
Aspen poplar 25

Buckbrush 5

Northern gooseberry 2

Northern bedstraw 3

Canada thistle 2

Common dandelion 2

Wild vetch 1

Veiny meadow rue 1

Bluebur 1

Fireweed 1

Awnless brome $\quad 70$

Range condition: poor

Successional status: seral
Star-flowered Solomon's seal 1 



\section{Poplar - Buckbrush - Wheat Grass community type}

This is a minor woodland community which occurs only sporadically in the Reserve. It is found most often in the coulees, where site specific conditions allow this community to grow. These conditions are usually present in small depressional areas or on slump benches, sites which are moister than the surrounding area, probably due to seepage along the coulee walls (see plate 12).

There is also one stand of poplar on the level mixed grasslands, located at the head of a small ephemeral drainage channel. It is a decadent stand, with most of the taller trees dead or dying. There is a dugout close by and the vegetation of this woodland has been heavily impacted by cattle.

Key and indicator species:

\section{Scientific name}

Graminoids

Festuca scabrella

Agrostis scabra

Forbs:

$\begin{array}{ll} & \begin{array}{l}\text { Vicia americana } \\ \text { Galium trifolium }\end{array} \\ & \text { Solidago canadensis } \\ \text { Shrubs: } & \begin{array}{l}\text { Symphoricarpos occidentalis } \\ \text { Rosa woodsii } \\ \text { Amelanchier alnifolia } \\ \text { Ribes oxyacanthoides }\end{array} \\ \text { Trees: } & \text { Populus balsamifera } \\ \text { Range classification: Secondary } \\ \text { Sites: field notes }\end{array}$

\section{Common name}

Rough fescue

Rough hair grass

\author{
Wild vetch \\ Sweet scented bedstraw \\ Canada goldenrod
}

Buckbrush

Common wild rose

Saskatoon

Northern gooseberry

Balsam poplar

Range condition: fair

Successional status: climax 


\section{EPHEMERAL RIPARIAN MEADOWS}

\section{Mixed Grass - Forb community type}

This community type occurs in ephemeral drainage channels in the upland grasslands. Locally favourable moisture conditions allow growth of an average of $17 \%$ cover of shrubs, primarily buckbrush and common wild rose. A lush forb layer is characteristic of this community type, except at one site (R18) where awnless brome had invaded (see plate 9).

Key and indicator species:

Scientific name

Common name

Rough fescue

Awnless brome

Green needle grass

Hooker's oat grass

Interior bluegrass

Western porcupine grass

Bromus inermis

Stipa viridula

Helictotrichon hookeri

Poa interior

Stipa curtiseta
Forbs:
Shrubs: $\quad$ Symphoricarpos occidentalis

Shrubs: $\quad$ Symphoricarpos occidentalis Rosa woodsii

Vicia americana

Epilobium angustifolium

Galium boreale

Artemisia ludoviciana

Castilleja lutescens

Thalictrum venulosum

Arnica fulgens

Campanula rotundifolia
Wild vetch

Fireweed

Northern bedstraw

Prairie sagewort

Stiff yellow paintbrush

Veiny meadowrue

Shining arnica

Harebell

Buckbrush

Common wild rose
Average

canopy cover

(\%)

18

13

8

7

4

2

5

4

4

$<1$

3

1

$<1$

$<1$

13

4
Range classification: Primary

Sites: 02, R17, R18, 27
Range condition: varies

Successional status: climax 


\section{Rough Hair Grass - Sedge - Forb community type}

This community type is found in coulee bottoms where soils are poorly drained. The site examined was affected by cattle grazing and trampling. Species composition included invader species typical of disturbed or heavily grazed sites, such as foxtail barley, Canada thistle and common dandelion (see plate 12).

Key and indicator species:

Scientific name

Graminoids: Dominant:

Agrostis scabra

Carex atherodes

Secondary species:

Poa palustris

Hordeum jubatum

Juncus balticus

Stipa viridula

Forbs:
Common name

Rough hair grass

Awned sedge

Fowl bluegrass

Foxtail barley

Wire rush

Green needle grass

Wild mint

Canada thistle

Smooth scouring-rush

Common dandelion

White cinquefoil

Buckbrush

Common wild rose

\section{Average \\ canopy \\ cover $(\%)$}

Shrubs:

Symphoricarpos occidentalis

Rosa woodsii

Range classification: secondary

Range condition: fair

Sites: \#20

Successional status: seral 


\section{WETLANDS}

\section{Bluegrass - Hair grass - Cinquefoil community type}

This community occurs in low relief depressional areas which are a ephemeral wetlands. The examined site had experienced moderate to heavy grazing. Characteristic graminoids of this community type were rough hair grass and fowl bluegrass. Two wetland sedge species, woolly sedge and meadow sedge, were also present, but in low cover. Several invader species were present, including common dandelion, foxtail barley and sow thistle. The presence of Nuttall's salt meadow grass, salt grass and gumweed is indicative of slightly saline soil conditions.

Key and indicator species:

Scientific name

Common name

Average

canopy cover

(\%)

Graminoids: Dominant:

$$
\begin{aligned}
& \text { Poa palustris } \\
& \text { Agrostis scabra }
\end{aligned}
$$

Secondary species:

Puccinellia nuttalliana

Carex lanuginosa

Carex praticola

Hordeum jubatum

Distichlis stricta

Forbs:

Potentilla anserina

Taraxacum officinale

Artemisia ludoviciana

Grindelia squarrosa

Achillea millefolium

Sonchus arvensis

Fowl bluegrass

Rough hair grass

Nuttall's salt-meadow grass 9

Woolly sedge 2

Meadow sedge 1

Foxtail barley 1

Salt grass $\quad<1$

Silverweed 12

Common dandelion 9

Prairie sagewort $\quad 6$

Gumweed 3

Common yarrow 1

Perennial sow-thistle $\quad<1$

Range classification: Primary

Range condition: fair

Sites: \#21

Successional status: seral 



\section{Sedge - Rough Hair Grass community type}

This community occurs in shallow depressions on the uplands or associated with ephemeral drainage channels. Moisture regimes within these wet lowlands vary from subhygric to subhydric. The wetland sedges and wire rush predominate in the wettest parts in the center of the wetland which are flooded for a longer period of time. Rough hair grass and fowl bluegrass are more prevalent in the somewhat drier conditions further out from the wetland center. In addition, moisture conditions in the wetlands will vary from season to season, and between years, depending on precipitation levels. The presence of the halophytic species, gumweed, may indicate a moderate degree of salinity. The wetland sedges are favoured by cattle, and this community had experienced moderate grazing.

Key and indicator species:

Scientific name

Common name

Average canopy cover

(\%)

Graminoids: Dominant:

Carex lanuginosa

Carex atherodes

Agrostis scabra

Poa palustris

Secondary species:

Juncus balticus

Hordeum jubatum

Forbs:

\section{Mentha arvensis \\ Artemisia ludoviciana \\ Grindelia squarrosa}

Range classification: Primary

Sites: 3, R02, R03
Woolly sedge $\quad 42$

Awned sedge $\quad 10$

Rough hair grass $\quad 25$

Fowl bluegrass 10

Wire rush $\quad 8$

Foxtail barley 3

Wild mint 1

Prairie sagewort $\quad<1$

Gumweed 1

Range condition: good

Successional status: edaphic climax 


\section{Sedge - Wire Rush community type}

Wet conditions arising from very poor drainage result in these nearly pure stands of wetland sedges. This community was found only within the outlet channel from Little Fish Lake. This site is usually flooded for much of the year, creating conditions favourable to aquatic sedges but resulting in low floristic diversity. Growth of these sedges occurs late in the spring, but they are palatable to cattle. The examined site was severely trampled by cattle (see plate 13).

Key and indicator species:

Scientific name

Common name

Douglas sedge

Wire rush

Juncus balticus

Forbs:

Ranunculus cymbalaria

Equisetum laevigatum

Range classification: Primary

Sites: \#15
Seaside buttercup

Smooth scouring-rush

Range condition: fair

Successional status: edaphic climax

\section{Average \\ canopy cover}

(\%)

40

5

1

\section{Marsh community}

A small dam built by Ducks Unlimited (Canada) in the 1966 to maintain high water levels in Little Fish Lake created a small reservoir adjacent to the shoreline of the lake. In dry years this reservoir is completely dry but it has remained wet for a long enough period of time that the site is evolving into a marsh (see plate 14). This reservoir/marsh has its own rudimentary aquatic vegetation community, composed of the following species:

Bulrush

Sedge

Water parsnip

Arrow-grass
Scirpus sp

Carex sp.

Sium suave

Triglochin sp.

In parts of the reservoir/marsh the bulrushes are dense enough to obscure the water. 



\section{DISTURBANCE COMMUNITIES}

\section{Truck tracks}

Truck tracks have worn ruts into the grasslands, thereby exposing mineral soil and allowing invader species to form a linear community (see plate 3 ). In general, the vegetation along this feature does not differ greatly from the vegetation community through which the truck tracks pass. The main difference is in the additional species which are allowed to grow. These species include:

Prairie sagewort

Pasture sagewort

Low everlasting

Selaginella

\author{
Artemisia ludoviciana \\ Artemisia frigida \\ Antennaria aprica \\ Selaginella densa
}

\section{Dirt road}

The fair weather dirt road along the west and south sides of section 25 (in the northeast corner of the Reserve) has a slightly raised shoulder which supports a continuous vegetation community. This community is visibly distinct from the natural Rough fescue grassland which borders it.

The plants found here are typical of species which are able to quickly colonize disturbed areas and waste ground. Five of the eleven species are introduced. Awnless brome, in particular, is able to invade into any disturbed area or favourable niche. This is evident by its presence in other, nearby vegetation communities (i.e. aspen copses, ephemeral drainage channels).

The following species make up this community along both sides of the dirt road.

Average canopy cover (\%)

Awnless brome

Pennycress

Prairie sagewort

Crested wheat grass

Tansy mustard

Perennial sow-thistle

Common blue lettuce

Gaillardia

Wild vetch

Wormseed mustard

Wild morning glory
Bromus inermis

Thlapsi arvense

Artemisia ludoviciana

Agropyron pectiniforme

Descurainia sophia

Sonchus arvensis

Lactuca pulchella

Gaillardia aristata

Vicia americana

Erysimum cheiranthoides

Convolvulus sepium
60 to 80

10 to 20

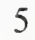

2 



\section{Reclaimed well site}

This is a small community found on an old petroleum well site, where as much as thirty percent of the site is exposed, non-vegetated mineral soil. The two most common species, Crested wheat grass and Awnless brome, are non-native grasses which were probably planted at the site. Some native species, including pasture sagewort, low everlasting and gumweed, are also found here. These species are characteristic of drier soil conditions.

\section{Average canopy cover (\%)}

\section{Graminoids}

Crested wheat grass

Agropyron pectiniforme

30

Awnless brome

Bromus inermis

Forbs

Pasture sagewort

Artemisia frigida

20

Low everlasting

Antennaria aprica

Grindelia squarrosa

Gumweed

$$
\text { Grindelia squarrosa }
$$

5

$\underline{\text { Shrubs }}$

Buckbrush

Symphoricarpos occidentale

5

Common wild rose

Rosa woodsii

1

\section{Dugout spoil piles}

Of the eight dugouts in the Reserve, seven have large spoil piles which have been left to revegetate naturally (the remaining dugout is older and the spoil piles have been moved). Each spoil pile is dominated by bare mineral soil, as they are only a few years old. These piles are characterized by low vegetation cover which is dominated by non-native and/or invader plant species. In places where the plant cover is continuous, it is comprised almost exclusively by Foxtail barley (see plate 14).

The vegetation cover of these sites is expected to change fairly quickly over the next few years as other species invade and become established.

\section{Dominant species}

Graminoids

Foxtail barley

Hordeum jubatum

Forbs

Golden aster

Pasture sagewort

Heterotheca villosa

Artemisia frigida 



\section{Secondary species}

Graminoids

Rough fescue

Rough hair grass

Slender wheat grass

Tufted hair grass

\section{Forbs}

Low everlasting

Common yarrow

Goldenrod

Silverweed

$\underline{\text { Shrubs }}$

Buckbrush
Festuca scabrella

Agrostis scabra

Agropyron trachycaulum

Deschampsia cespitosa

Antennaria aprica

Achillea millefolium

Solidago spathulata

Potentilla anserina

Symphoricarpos occidentale

\section{Vegetation community diversity}

There is a considerable range of plant species diversity between the vegetation communities of the Reserve. Table 1, which lists all the community types in decreasing level of diversity, illustrates this quite clearly. The most diverse communities are the shrub and mixed grass communities, followed by the ephemeral riparian meadows. The coulee woodlands rank in the upper half of the list. The three wetland communities are the least diverse.

Overall, the greatest plant diversity in the Reserve is found in the coulees and, to a lesser extent, along the escarpment. The reasons for this are quite simple: these areas hold the most diverse topography and hence, the most varied environmental sites in terms of slope position, insolation, wind exposure and available moisture. There appears to be a considerable amount of moisture seepage near the surface along the slopes of the coulees and the escarpment. Thus, it is not surprising that in this dry prairie landscape, the most important factor controlling plant diversity is the availability of water.

The most extensive vegetation communities in the Reserve do not have a very high degree of plant diversity as compared to the other communities. The Rough fescue grasslands have only ten species while the Rough fescue - Western porcupine grasslands have seventeen species. This is much lower than the Rose - Rough fescue - Forb shrubland or the Rough fescue - Green needle grass - Forb grassland, both of which have an average of thirty-seven species. 

Community

type
Number of plant species

shrub forb gram tree total

\begin{tabular}{|c|c|c|c|c|c|c|}
\hline Rose - Rough Fescue - Forb & shrubbery & 8 & 21 & 8 & 0 & 37 \\
\hline Rough Fescue - Green Needle Grass - forbs & mixed grassland & 3 & 27 & 7 & 0 & 37 \\
\hline Salix/Saskatoon - Rough Fescue/Bluegrass & shrubbery & 10 & 20 & 6 & 0 & 36 \\
\hline $\begin{array}{l}\text { Rough Fescue - June Grass - Juniper - } \\
\text { Forbs }\end{array}$ & mixed grassland & 4 & 21 & 6 & 0 & 31 \\
\hline Rough Hair Grass - Sedge - Forb & meadow & 5 & 14 & 12 & 0 & 31 \\
\hline Mixed Grass - Forb & meadow & 2 & 16 & 8 & 0 & 26 \\
\hline Aspen - Buckbrush - Forb - Wheat Grass & woodland & 5 & 13 & 6 & 1 & 25 \\
\hline $\begin{array}{l}\text { Western Porcupine Grass - Rough Fescue - } \\
\text { Forbs }\end{array}$ & mixed grassland & 1 & 14 & 8 & 0 & 23 \\
\hline June Grass - Sedge - Sagewort - Selaginella & mixed grassland & 2 & 13 & 6 & 0 & 21 \\
\hline Needle and Thread - Sedge - Selaginella & mixed grassland & 2 & 11 & 7 & 0 & 20 \\
\hline Buffaloberry - Rough Fescue & shrubbery & 6 & 6 & 6 & 0 & 18 \\
\hline Rough Fescue - Western Porcupine Grass & mixed grassland & 1 & 11 & 5 & 0 & 17 \\
\hline Poplar - Buckbrush - Wheat Grass & woodland & 8 & 4 & 2 & 1 & 16 \\
\hline Gumweed - Bluegrass - Foxtail Barley & mixed grassland & 1 & 9 & 5 & 0 & 15 \\
\hline Bluegrass - Rough Hair Grass - Cinquefoil & wetland & 0 & 7 & 7 & 0 & 14 \\
\hline $\begin{array}{l}\text { Silverberry - Rough Fescue - Hooker's Oat } \\
\text { Grass }\end{array}$ & shrubbery & 2 & 8 & 3 & 0 & 13 \\
\hline Aspen - Awnless Brome & woodland & 3 & 7 & 1 & 1 & 12 \\
\hline Rough Fescue & fescue grassland & 0 & 6 & 4 & 0 & 10 \\
\hline Buckbrush - Rough Fescue & shrubbery & 2 & 5 & 2 & 0 & 9 \\
\hline Sedge - Rough Hair Grass & wetland & 0 & 2 & 0 & 7 & 9 \\
\hline Sedge - Wire Rush & wetland & 0 & 2 & 2 & 0 & 4 \\
\hline
\end{tabular}

Table 1: Floristic diversity of the vegetation communities. This is based on the mean number of species expected in each community. These numbers will vary somewhat, between locations and years, due simply to natural ecological variation .

Shrub: tall and low shrub species

Forb: forb species

Gram: graminoid species, which includes grasses, sedges and rushes

Tree: tree species

Total: total number of species 



\subsection{Range}

Range condition varies widely throughout the Reserve, as is shown on the Range Condition map.

\section{Excellent range}

Range in excellent condition is found mainly in Rough Fescue grasslands and, to a lesser extent, in the Rough Fescue-Western Porcupine Grass community (see plates 4, 5 and 6). These grasslands are located in several main areas, the most extensive of which covers the southern highlands and most of the western part of the Reserve (coulees and escarpment not included). Some of this area is fenced off from grazing but is hayed on a two to three year rotation. The rest is within a grazing lease but located away from water sources and is protected to some degree by the deep coulees, which impede easy access by cattle.

Excellent range is also found just north of Little Fish Lake. It is also within a grazing lease but, again, it is located some distance from water. Well worn paths leading from the marsh to other areas away from the north shoreline of the lake suggest that this area is not often visited. The field surveys found few signs of cattle use in this thick fescue grass.

Section 25, in the northeast corner of the Reserve, is restricted to haying, so most of its Rough Fescue grasslands are in excellent condition. However, as the range condition map indicates, only half of this section is rated in excellent condition. The eastern half of section 25 was hayed the summer before the field work was done. Although haying does not impact fescue grasslands quite as strongly as does grazing it still does have a pronounced effect. Haying reduces the quality of the fescue grassland, thereby changing it into a mixed grassland, mainly a Rough Fescue-Western Porcupine Grass community (Wallis 1990). If left unhayed, it will revert back to a Rough Fescue grassland within a few years.

The protective effect of fences is clearly illustrated along the northwest shore of Little Fish Lake. In 1990, fences were built along the high-water shoreline to keep cattle off the lake basin and away from nesting Piping Plovers. The thin strip of grass between the fence and the shoreline is in excellent condition. The mixed grasslands on the other side of the fence, which continue to be grazed, are in fair to poor condition.

\section{Good range}

Range in good condition is scattered throughout the Reserve. There are small patches on the southern highlands and along the escarpment, mainly small areas of shrubbery. In the southern half of the Reserve, good range is found on Dark Brown Chernozemic and Solonetzic soils on the plain around the base of the southern highlands, in mixed-grass and meadow communities. In the northern half, it is found mainly on Black Chernozemic and Dark Brown Solod soils. The vegetation in this case is almost exclusively Rough Fescue-Western Porcupine Grass.

The vegetation of the central and northern coulee is predominately good range. It is composed of mixed-grasslands, shrubbery and small woodlands on predominantly Regosolic soils. 

There are some small areas of good range interspersed among large areas of poorer range. These areas are mainly moist wetlands which have richer grass than the surrounding uplands.

\section{Fair range}

Four of the seven mixed-grass communities in the Reserve have much of their areal extent classified as range in fair condition.

Virtually all of the range lands in this category, outside of the escarpment and the ephemeral drainage channels, consist mainly of the Western Porcupine Grass-Rough Fescue-Forb community, with lesser areas of June Grass-Sedge-Sagewort-Selaginella (see plate 7). Most of these areas are underlain by Solonetzic soils, which inhibits continuous plant cover.

With the exception of some small patches of shrubbery, all of the vegetation below the escarpment, which is found on Dark Brown Chernozems and Regosols, is classified as fair range.

Most of the ephemeral drainage channels in the Reserve which are subject to grazing were found to be in fair condition.

\section{Poor range}

Lands in poor range condition are found in only two parts of the Reserve. In the central area are several large areas with Gumweed-Bluegrass-Foxtail Barley and June Grass-Sedge-SagewortSelaginella communities growing on Solodized Dark Brown Chernozems or Solonetzic soils (see plates 8 and 9). This region is also heavily used by cattle because it either surrounds a water source or there is a nearby dugout.

All of the aspen copses in the northeast corner of the Reserve are considered poor rangelands. In the eastern half of this section (section 25) the ephemeral drainage channels were hayed the year previous to the field work. This simple activity changed the range condition of these channels from excellent to poor.

Table 2 illustrates the different range conditions which are found within each vegetation community. 




\subsection{Wildlife}

\section{Butterflies}

Butterflies are not often considered as important components of an ecosystem, especially for the purposes of a biophysical survey. However, as more becomes known about their life-cycles and habitat requirements, butterflies are gaining importance as bio-indicators. Most species of butterflies have very specific habitat requirements (Pyle 1984) and many require specific plants or groups of related plants for survival of the juvenile stage (Watson et al 1975). Thus, if certain species of butterflies are disappearing from an area, it is quite possible that their habitats or host plants are being degraded or lost in a non-obvious way.

There are about 170 species of butterflies in Alberta, and the largest number of species normally found at any one locality is about seventy (Bird et al 1995). A literature survey has revealed that there are potentially sixty-five species which occur in the Reserve. The number of species in each habitat type would be as follows:

$\begin{array}{lc}\text { Habitat } & \text { No. species } \\ \text { Grasslands } & 32 \\ \text { Coulees } & 11 \\ \text { Meadows } & 7 \\ \text { Shrubbery } & 5 \\ \text { Woodlands } & 4 \\ \text { Wetlands } & 3 \\ \text { unknown } & 2 \\ \text { migrant } & 1\end{array}$

No systematic surveys of butterflies were done as a part of this study. However, it was noted that butterflies were very numerous and that their diversity seemed quite high. This may be due to the spring season which preceded the field work: it had been very wet, a fact which resulted in spectacular flower blooms in the Reserve. Butterflies are important pollinators of flowering plants (Emmel 1975) and, in Alberta, butterfly diversity is highest following a moist spring (Bird et al 1995).

\section{Fish}

Based on the size and types of waterbodies in the Reserve, there are probably only three species of fish which may be found: the Lake Chub, Fathead Minnow and Brook Stickleback. However, it is unlikely that any fish would be currently found in the Reserve, for the following reasons.

All of the natural waterbodies in the Reserve are shallow and, thus, likely to freeze to the bottom in winter. Even if they did not freeze completely, they are shallow enough that oxygen depletion is 

likely to occur. Since there has been no water flowing out of Little Fish Lake since the 1960's, the main waterbodies in the drainage channels have not been naturally restocked with fish from the lake in a very long time.

Due to the presence of the dam, there would probably be no replenishment of the marsh from Little Fish Lake, even in high water years. The dugout and shallow pond near the shoreline, south of the reservoir/marsh, may be replenished with fish from the lake in high water years.

It is doubtful that there are any fish in the numerous dugouts which are scattered across the Reserve. The aquatic habitat in most of them is not conducive to fish and, again, winter-kill and the lack of a consistent replenishing source would preclude any long term survival of any fish population.

\section{Herpetofauna}

Six species of amphibians should be found in the Reserve. This includes one salamander, two toads and three frogs. Of the frogs, wood frogs and boreal chorus frogs were commonly heard around the natural wetlands which had standing water. Only one frog was recorded in a dugout, a wood frog.

There were several populations of the Northern Leopard Frog in the vicinity of the Hand Hills up until the early 1980's, after which they disappeared (Roberts 1992). All remaining populations are now located in the extreme southern part of the province. Since this species requires permanent wetlands (Roberts 1981), it is unlikely that any would have survived in the Reserve over the last decade

Six species of snakes may also be present in the Reserve. The three species of garter snakes would usually be found near water but could also be found in the dry grassland (Russell and Bauer 1993). The bull snake and prairie rattlesnake are present in the Hand Hills but since they prefer rockpiles and sandy exposures in the grasslands, they may not occur in the Reserve. This kind of habitat does occur just outsidew the western boundary of the Reserve. 



\section{Birds}

A total of 137 birds are expected to occur in the Reserve. This number includes residents who breed in the Reserve or use the area on a regular basis for such activities as foraging, and migrant species who use the Reserve as a stopover or staging area. A breakdown of these birds by taxonomic group gives the following:

$\begin{array}{lr}\text { Bird Group } & \text { no. Species } \\ { } } & 19 \\ \text { Raptors } & 12 \\ \text { Upland birds } & 2 \\ \text { Shorebirds } & 22 \\ \text { Larids } & 6 \\ \text { Flycatchers } & 4 \\ \text { Warblers } & 5 \\ \text { Sparrows } & 12 \\ \text { Finches } & 4 \\ \text { Others } & 51\end{array}$

The different habitats of the Reserve have very different avian communities, according to the vegetation community structure and composition, and the presence or absence of water. The number of species found in each habitat type is as follows:

$\begin{array}{lc}\text { Habitat } & \text { no. Species } \\ \text { Grasslands } & 36 \\ \text { Shrubbery } & 18 \\ \text { Woodlands } & 28 \\ \text { Coulees } & 30 \\ \text { Wetlands } & 41 \\ \text { Little Fish Lake } & 32\end{array}$

The Reserve does not include any waters of Little Fish Lake but does encompass all parts of the lake basin above the waterline. The types of birds which would be found in this area include the following:

$\begin{array}{lc}\text { Bird Group } & \text { no. Species } \\ \text { Waterfowl } & 17 \\ \text { Shorebirds } & 11 \\ \text { Larids } & 4\end{array}$

Of the shorebirds, ten species are migrants and one is a resident breeder. 

There are twenty-eight bird species which would be found in the Reserve solely during migration. These birds include:

$\begin{array}{lc}\text { Bird Group } & \text { no. Species } \\ \text { Waterfowl } & 2 \\ \text { Shorebirds } & 11 \\ \text { Passerines } & 15\end{array}$

Grassland avifaunas usually have fewer breeding species than forests (Degraaf et al 1991) but the grasslands of the Reserve have a higher diversity than does the woodlands. This is probably due to the greater vegetative diversity across the grasslands, as well as its much greater areal extent.

In addition, grassland avifaunas are often dominated by a few species (Wiens and Dyer 1975). The most common birds in the grasslands are the Sprague's Pipet, Western Meadowlark and Baird's Sparrow, which are far more common than the other species.

Grazing levels exert a strong effect on the composition of grassland avifaunas. Species favouring ungrazed or lightly grazed areas include the Sharp-tailed Grouse, Upland Sandpiper, Sprague's Pipit, Baird's Sparrow and Savannah Sparrow (Wallis 1990). As the level of grazing intensifies species such as the Long-billed Curlew and Horned Lark become more common (Wallis 1990). The former group of birds was recorded far more often in the Reserve than the latter group.

Upland Sandpipers, which were present in the area in 1981, had disappeared by 1984, presumably due to over grazing (Wallis and Wershler 1985), They were found to be common in 1996. Adult birds were recorded over much of the central part of the Reserve, and one brood of young was also found.

Shrub habitats are found in coulee and grassland areas as well as along the escarpment. Of these areas, the most diverse was the tall mixed shrub community on north facing coulee slopes. It attracts an avian community vastly different from that of the grasslands. Whereas grasslands are dominated by one group of birds, the sparrows, avian diversity is more equitable in the tall shrub habitat. Catbirds, warblers, goldfinches, waxwings, sparrows, and magpies are common in this habitat. Several of these species will nest in the shrubs and forage in different habitats, such as the grasslands or woodlands.

Woodland habitats in the prairies have a high avian diversity for two reasons: it provides nesting sites for woodland birds and edge habitat for many grassland species (Degraaf et al 1991). In the Reserve, this diversity is enhanced by the proximity of the Hand Hills to the ecotonal region between the Northern Fescue and Aspen Parkland ecoregions.

The largest and most diverse avian community is that of the wetlands. This community includes waterfowl, shorebirds, larids, and passerines. It is diametrically opposed to the grassland habitats. The grasslands are extensive, so the birds can spread out, thereby minimizing antagonistic 

interactions or competition for resources. However, the wetlands are few in number and small in size with the result that the birds are concentrated much more densely.

\section{Grazing effects on birds}

The extent to which grazing affects breeding avifaunas depends on the intensity of grazing and the rangeland type (DeGraaf et al 1991). With light grazing there is generally little change in either vegetation or avian communitites. But when grazing intensity is high, vegetation composition changes and so does the avian community, usually towards that more characteristic of xeric habitats (Owens and Myres 1973).

There is little debate on the fact that grazing does affect bird populations. Research has found that grazing is harmful to the nesting success of waterfowl (Weller et al 1958) and has caused declines in the populations of some species, such as the Lesser Prairie Chicken (Brown 1978) and the Sharptailed Grouse (Miller and Graul 1980). Long-term changes in an avian community occur if grazing levels persist such that the original vegetation community is not allowed to re-establish (DeGraaf et al 1991).

Different avian communities will result from different grazing regimes. For example, species such as the Baird's Sparrow, Sharp-tailed Grouse, Upland Sandpiper, Grasshopper Sparrow, Sprague's Pipit and Savannah Sparrow require ungrazed or lightly grazed grasslands (Wershler and Wallis 1986, Wallis 1990, 1991). Other species, including the Long-billed Curlew, McCown's Longspur, Ferruginous Hawk and Burrowing Owl, prefer moderately to heavily grazed areas (Wershler and Wallis 1986, Wallis 1991).

In the Reserve, those species characteristic of ungrazed to lightly grazed rangelands were commonly recorded. The Long-billed Curlew, McCown's Longspur and Burrowing Owl were not found in the Reserve. These two facts indicate that, overall, the rangelands in the Reserve are in fairly good condition.

Controlling the intensity, timing and location of grazing will ensure that a mosaic of range conditions and vegetation communities are maintained. This will also maintain and conserve the diverse bird populations in the Reserve. 



\section{Species at risk}

There are several species which occur in the Reserve whose populations are considered at risk due to a variety of factors. The Committee on the Status of Endangered Wildlife in Canada (COSEWIC) has determined that the following species are notable due to their current status:

Piping Plover - designated Threatened 1978, Endangered 1985.

Burrowing Owl - designated Threatened 1979, Endangered 1995.

Loggerhead Shrike - designated Threatened 1986.

Ferruginous Hawk - designated Threatened 1980, Vulnerable 1995.

Long-billed Curlew - designated Vulnerable 1992.

Baird's Sparrow - was designated Vulnerable; de-listed in 1996.

\section{Piping Plover}

The Hanna area, which includes Little Fish Lake, Handhills Lake, Spiers Lake, Dowling Lake and the Chain Lakes, have held $42 \%$ to $57 \%$ of the Alberta population of Piping Plovers, a figure which represents about $5 \%$ of the North American population (Morrison et al 1991). Among these lakes, Little Fish Lake has supported the highest numbers of individuals in Alberta: forty-nine in 1989 (Wershler 1989) and forty-eight in 1990 (Hofman 1994). In terms of young hatched, nearby Handhills Lake has been the most productive site (Morrison et al 1991).

An intensive survey of all known Piping Plover lakes in southern and central Alberta, done as part of the 1991 International Piping Plover census in Canada, found that Little Fish Lake was one of the most important lakes in Alberta, in terms of breeding habitat and numbers of adults (Hofman 1994). Nearby South Handhills Lake was also rated just as highly.

The flat shoreline of Little Fish Lake extends to within the boundaries of the Reserve. The preferred breeding habitat of Piping Plovers within this area is quite specific: exclusively on exposed pebbly or sandy beaches (Caza 1985, Burnett et al 1989).

\section{Burrowing Owl}

No individuals of this species were recorded in the Reserve during the field work. However, the Reserve does have the preferred habitat for this species.

They require large holes in the ground in which to nest and seek shelter from both the weather and their main predator, large hawks (Burnett et al 1989). Generally, old ground squirrel or badger burrows are used (Wershler and Wallis 1986). They prefer open landscapes, with short grass surrounding the nesting burrows and nearby tall grass for foraging (Nadeau 1996). This habitat type is widespread in the central part of the Reserve, complete with many abandoned burrows.

The probable reason why this species is not found in the Reserve is simple: extremely low numbers of this species persist throughout the prairies. Intensive monitoring programs suggest a continuing decline of this species, especially in Alberta and Saskatchewan, where most of the Burrowing Owls in Canada are found (Nadeau 1996). 

As of 1995 the total number of breeding pairs in Canada was at an historically low number (Nadeau 1996). The probable cause for this continued decline is the use of chemical pesticides to control grasshoppers (Burnett et al 1989).

\section{Loggerhead Shrike}

This species has quite specific habitat requirements: willow thickets near sloughs or stands of tall shrubs in open country (Burnett et al 1989). Shrikes were often seen among the aspen copses and in the fescue grasslands where tall shrubs, such as Choke cherry, were scattered about.

Populations of this species have declined since the 1960's across the prairie provinces, with widespread abandonment of the northern portions of their traditional range (Cadman 1985, Burnett et al 1989). This species is believed to still be in decline although the reasons for this are unclear (Wildlife Management Branch 1991)

Shrikes were often seen along the dirt road which runs by the south side of section 25 . This area has a fence line and several aspen copses, which provide nesting habitat and perches. Shrikes are rather unique in that they store prey after it has been captured. The trees and shrubs of the aspen copses provide many sites in which to hide prey items.

Shrikes were occasionally recorded in the more open grasslands. In these areas, they prefer areas which have scattered tall shrubs or fencelines.

\section{Ferruginous Hawk}

Ferruginous hawks were recorded several times during the field work. These birds require open grasslands with large populations of ground squirrels, as these animals make up almost eighty percent of their diet (Nadeau 1996). So in order to maintain healthy populations of this species, large tracts of natural grasslands are required (Burnett et al 1989).

Populations of this species are considerably lower than the levels determined by historical records. However, population levels are thought to be steadily increasing (Wildlife Management Branch 1991).

\section{Long-billed Curlew}

The Long-billed Curlew has undergone Large reductions in its population size, due in part to loss of its primary habitat: large tracts of open grassland (Semenchuk 1992). The highest densities of this species occurs in moderately grazed grassland (Semenchek 1992).

No individuals of this species was recorded during the field work but it was found on nearby saline lakes, just to the west of the Reserve.

\section{Baird's Sparrow}

In the early part of this century, the Baird's Sparrow was considered an abundant species of the mixed-grass prairie in Alberta (Burnett et al 1989). Less than five percent of that population level 

is present today, a decline which has been linked primarily to habitat loss (Burnett et al 1989, Semenchuk 1992). Although this species has been recently de-listed by COSEWIC, it may still be rare and/or declining over much of its range (Wallis 1990).

The preferred nesting habitat of the Baird's Sparrow is tall fescue grassland with a thick litter layer and abundant scattered shrubs (Nadeau 1996, Pashley 1996). The preferred nest sites are on the ground in small depressions beneath a tussock of grass or a shrub (Burnett et al 1989).

The nesting habitat has to be either ungrazed, or at most lightly grazed, otherwise the bird will not use it (Wallis 1991). On ungrazed grasslands this species has reached nesting densities as high as 22.5 pairs per hectare (Burnett et al 1989). Some research has found that grasslands subjected to a rotational grazing regime will support ten times as many birds as will a continuously grazed grassland (Nadeau 1996).

The Baird's Sparrow is most common in the Northern Fescue grassland region (Wallis 1991) and within this region, some of the highest densities have been recorded within the Reserve (Owens and Myres 1973, Wershler 1990). During the field work for this study, Baird's Sparrows were often heard singing in ungrazed or very lightly grazed fescue grasslands, mainly in the southern part of the Reserve.

\section{Waterfowl}

The few wetlands within the Reserve are heavily used by resident waterfowl. Nine species of dabbling ducks were recorded on the marsh, ponds and dugouts, with the marsh receiving the heaviest use.

The degree of vegetative cover along the edges of wetlands influences nest site selection by ducks. In central Alberta, ducks prefer vegetation twenty to forty centimetres tall (Long 1970), composed principally of bulrushes (Scripus sp.), mixed grasses, and low shrubs such as buckbrush (Symphoricarpos occidentale) and gooseberry (Ribes sp.) (Smith 1971). The presence of bulrushes and sedges (Carex sp.) is important for concealing broods (Nietfeld 1986). All the wetlands of the Reserve are heavily impacted by cattle use, especially the edges where the shoreline vegetation has been trampled.

Wetlands which are surrounded by undisturbed vegetation produce greater amounts of the invertebrate food which forms a large part of the diet of dabbling ducks than do areas disturbed by cattle (Schmidt 1981).

The flat, muddy shoreline of Little Fish Lake is extensively used by migrant waterfowl as a staging area.

\section{Shorebirds}

The wetlands and grasslands of the Reserve are used by a variety of shorebirds. Seven species were recorded, with the majority of sightings being centred around the marsh. 

Little Fish Lake is an important stopover area for migrating shorebirds, principally due to its large shoreline area. The Hanna area, encompassing Little Fish Lake, Handhills Lake, Spiers Lake, Dowling Lake and Chain Lakes, are being suggested as a potential Western Hemisphere Shorebird Reserve for migrant shorebirds (Morrison et al 1991).

\section{Sharp-tailed Grouse}

Sharp-tailed Grouse have very specific habitat requirements. General requirements are large areas of native grasslands in various stages of succession ( Kirsch 1969, Knapik and Westworth 1984). Homogeneous grasslands are unattractive as they lack the shrub and woodland component which provides the necessary cover and forage habitat (Knapik and Westworth 1984). The optimum habitat is a mosaic of vegetation communities, specifically grasslands with scattered shrubs and trees, with extensive edge habitat (Moyles 1981).

This species uses dancing grounds (leks) as part of its reproductive behaviour. The leks are located in an area of relatively sparse vegetation (Semenchuk 1992) with nearby low shrubs for roosting (Moyles 1977). Two leks have been reported in the Reserve; one in the fescue grassland of section 25 and one in mixed grassland in the southeast part. Both of these records are at least a decade old and it is not known if they are still used. However, females usually nest within one kilometre of the dancing grounds (Pepper 1972), and females with broods were recorded several times in different parts of the Reserve. It is probable that at least one active lek is still present.

Nesting habitat is found in dense grass with a low shrub component, generally with heavy cover (Jones 1968, Pepper 1972).

The habitat preferences of Sharp-tailed Grouse vary throughout the year (Moyles 1981). In summer, hens and their broods feed in grass-shrub communities and roost in nearby heavy cover, such as edges of woodlands or aspen copses (Pepper 1972, Sealy and Sexton 1976). As the summer progresses and the herbaceous plants of grasslands become desiccated, the broods move into more woody and shrubby cover (Brown 1966). By the onset of winter the grouse form large flocks which move into woodlands and shrubbery, to feed on aspen, chokecherry, willow and birch (Harris 1967, Semenchik 1992). They remain in dense cover to feed throughout the winter (Moyles 1981).

Grazing has a strong effect on this species. Heavy grazing will reduce the grass-shrub vegetation used for nesting and cover (Mattise 1978). Even light grazing can deplete the grasslands to the point where Sharp-tailed Grouse populations are reduced or eliminated (Kirsch 1969, Pepper 1972, Yde 1977). 



\section{Mammals}

Up to thirty-four species of mammals may occur in the Reserve. A breakdown of the number of species by groups is as follows:

\begin{tabular}{lc} 
Mammal Group & no. Species \\
\hline Shrews & 3 \\
Bats & 4 \\
Ground Squirrels & 3 \\
Cricetids & 6 \\
Carnivores & 2 \\
Mustelids & 6 \\
Deer & 2 \\
Other & 8
\end{tabular}

\section{Richardson's Ground Squirrel}

Richardson's Ground Squirrels were not thought to be as abundant in 1996 as was described by Wallis (1990). In turn, Wallis and Wershler (1985) found that it was less common in 1984 than in 1970. Most of the burrows found in 1996 were not occupied. It's possible that this species is undergoing a gradual population decline in the region.

The greatest number of Richardson's Ground Squirrel were still recorded in the same area. They are most abundant in areas of solonetzic soils and where there is considerable exposed mineral soil due to favourable topography. This means the central part of the Reserve and along the base of the escarpment (see Significant Features map).

This species is quite important because it forms a large part of the diet of many other species, including the badger, coyote, golden eagle and other raptors, such as the uncommon Ferruginous Hawk (Webb at al 1967).

\section{Thirteen-lined Ground Squirrel}

No individuals of this species was found in the Reserve in 1996. Again, Wallis and Wershler (1985) thought that this species was less common in 1984 than in 1970. It too may be declining in numbers. It is the only mammal species which prefers lush fescue grassland to more open mixed grasslands (Wallis 1990).

\section{White-tailed Deer}

The preferred habitat of the White-tailed Deer is a mixture of open grassy areas for foraging with nearby woodlands or tall shrubs for cover (Knapik and Westworth 1984). This means that in the prairie region, this species is restricted mainly to river valleys and coulees (Nietfeld et al 1985). Coulees are especially important because they provide shelter, browse and escape terrain (Stelfox 1979). Coulees also are preferred sites for fawning (Thomas 1979). 

The optimum browse for white-tails, particularly during winter, is found in the coulees. This includes dense stands of rose, willow, chokecherry, saskatoon, snowberry, silverberry and red-osier dogwood (Harmoning 1976, Stelfox 1979, Knapik and Westworth 1984). Some shrub stands in the coulees and along the escarpment showed signs of moderate browse over the past year.

In winter this species is concentrated in wooded areas which are topographically sheltered, such as the coulees.

White-tailed Deer were seldom seen in the Reserve, presumably because of their desire to stay near wooded or shrubby areas. This species seldom travels more than 180 meters from cover when foraging (Thomas 1979).

\section{Mule Deer}

Mule Deer prefer more open and rugged terrain than do White-tailed Deer. They use the steeply sloping terrain of the coulees and escarpment more then White-tails (Knapik and Westworth 1984) and will frequent open grasslands as long as it has scattered trees or tall shrubs (Wallmo 1978). There is a fairly strong association between steep, rugged terrain and Mule Deer distribution (Nietfeld et al 1985).

In open prairie habitats Mule Deer will fawn in deciduous thickets (Wallmo 1978).

Preferred winter habitat is south-facing slopes where snow cover is thin, allowing better access to grasses and forbs (Martinka 1967). Several antlers of this species were found in the Reserve, almost all of which were located on the south-facing of large coulees.

Mule Deer feed on much the same plant species as do White-tailed Deer. The summer diet consists of the new growth of forbs and shrubs, while winter browse consists of choke cherry, saskatoon, redosier dogwood, juniper, buckbrush and aspen (Wallmo 1978).

Mule Deer are perfectly suited to the kind of habitat mosaic found in the Reserve. However, they are sensitive to grazing and its related human disturbances, which have the result of restricting their distribution to the rugged topography of the escarpment and coulees (Nietfeld et al 1986).

\section{Pronghorn}

Pronghorn are animals of the open prairie. During the summer they are found on native grasslands with little or no shrub cover (Barrett 1982), generally on level to low rolling terrain with no large physical barriers, i.e. lakes, thick shrubbery or woodlands (Fish and Wildlife Division 1990). They seldom occur on steep slopes greater than 30\% (Yoakum 1978).

Vegetation type is also important to pronghorn. Preferred habitats have a vegetation community consisting of 40 to 60 percent grass, 5 to 20 percent shrubs and 10 to 30 percent forbs (Yoakum 1978).

A diverse community is preferred over monotypic vegetation types. 

Pronghorn were often seen in the Reserve, almost always on the slopes and rolling top of the southern highlands, generally in the mixed-grass areas.

The diet of pronghorn in spring consists of the new growth of grasses and sedges (Mitchell 1980). During the summer, grass and sedge consumption was replaced by an increased use of forbs such as pasture sage, goat's beard, golden aster and yarrow (Mitchell 1980). In dry years, wetland communities become important sources of grasses and forbs (Good and Crawford 1978).

Pronghorn need free water distributed at maximum intervals of eight kilometres throughout the year. (Kindschy et al 1978). The marsh, dugouts and ponds in the Reserve all meet this requirement.

Tops or slopes of hills are commonly used for fawning (Barrett 1981).

Pronghorn in Alberta migrate between summer and winter ranges. The nearest major wintering range is approximately eighty kilometres from the Hand Hills. The Reserve does not have the required winter browse of this species: dense stands of silver sagebrush.

Man-made obstacles, such as fences, have a significant impact on Pronghorn, especially their ability to migrate to winter ranges (Oakley 1973). They occasionally become caught in fences but the extent of the problem caused by fence lines is unknown (Fish and Wildlife Division 1990). Pronghorn on the Reserve seemed to have no problem getting past fences.

In addition to fences, pronghorns are susceptible to disturbances along roadways, especially if the vehicular activity is irregular (Autenreith 1978). Vehicle traffic in the Reserve was very light but it still had a visible effect on the Pronghorn. Even distant trucks travelling slowly would cause the animals to flee. Most such reactions resulted in the animals moving completely out of sight. 



\subsection{Significant Features}

The Reserve contains a number of significant features, ranging in importance from local to international significance. The designations for significance levels is adapted from Wallis (1991).

Significance level

Local

Regional

Provincial

National

International

\section{Criteria}

Features that are the best examples within the Hand Hills.

Features that are of limited distribution or are the best examples of a feature in the study region, in this case, the region surrounding the Hand Hills.

Features that are limited in distribution at a provincial level or that are the best examples of features in Alberta.

Features that are limited in distribution at a national level or that are the best or only representatives in Canada.

Features that are unique in the world or are of universal significance.

The designation given for each feature was derived using information gathered from a number of sources: field notes for this study, references on significant features evaluation (Nelson et al 1988, Lord 1991 ) and previous studies done in the region (i.e., Cottonwood 1986, Wallis and Wershler 1985, Wallis 1990, Wershler and Wallis 1990, Cottonwood 1991, Wallis 1991). The location of these features in the Reserve is given on the Significant and Special Features map.

\subsection{Significant Landform Features}

Local Significance

The sand hills are interesting features in that they have a distinctive rounded shape but not the crossbedding or layering that would be found within wind sorted features, i.e. dunes. There are probably more of these features in the Hand Hills.

The remnant beach ridges are not often found because they are formed from pure silt, a substance which is easily eroded by both wind and water. There is another long set of these ridges just to the east of the Reserve, adjacent to the north shore of Little Fish Lake.

The drumlin is uncommon for the region. 



\section{Regional Significance}

The Kneehills Member of the Edmonton Formation is a layer of highly bentonitic shale. It is known as a persistent, widespread and highly recognizable marker for the Edmonton Formation and outcrops only in uncommon situations such as badlands or the slopes of river valleys (Campbell 1974). There is a small piece of badlands topography near the base of the escarpment, where this layer of shale has been mapped.

The coulees along the western boundary of the Reserve are unusual in that they are large topographic features which suddenly fade to insignificant proportions as they reach the western edge of the escarpment (see plates 11 and 12).

In regards to the topographic feature which resembles concentric rings, no records of this type of feature are known for this region and its' genesis is also purely speculative. It is, at the very least, quite uncommon.

\section{Provincial Significance}

The Hand Hills is one of the most prominent hill systems in the prairie region and one of only ten known tertiary plateaux, with associated gravel deposits and conglomerate bedrock outcroppings, in the province (Storer 1978).

The escarpment is one of the few such features in the prairies. All other similar features, with the exceptions of sites such as the Cypress Hills, are associated with river valleys (see plates 1 and 2).

\section{National Significance}

The gravelly shore of Little Fish Lake. It is the most important component of the breeding habitat of the Piping Plover, which is an endangered species.

\subsection{Significant Ecosystems}

International Significance

The Northern Fescue Grasslands in the Reserve represent the largest remaining block of relatively undisturbed fescue grasslands left in the world. As such, it is an endangered ecosystem.

The need to protect the fescue grasslands in the Reserve is of paramount importance because all other known locations of this grassland type are less extensive and more heavily grazed (Wershler and Wallis 1990). The best fescue grasslands in the Reserve occur in sections 25 and 11, both of which are restricted to haying and thus, protected from cattle grazing. 

There are also specific plant communities which are restricted to this type of ecosystem, such as the lush riparian forb meadows. These meadows contain species which are not only representative of the fescue grasslands but some which are more common in foothill grasslands, such as the shining arnica and the heart-leaved buttercup.

\subsection{Significant Flora}

Local Significance

The large coulees in the Reserve contain highly diverse coulee shrubbery. Most coulees in the region have either a grassland cover or sparse shrubbery (see plate 12).

The Western Wood Lily (Lilium philadelphicum) is uncommon in fescue grasslands (Cottonwood 1986). The field surveys for this study were done in a very wet summer and this species was commonly found in localized sites, such as the ephemeral riparian meadows and along moist parts of the coulee and escarpment slopes.

\section{Regional Significance}

There are isolated springs located along the coulee walls, with associated significant vegetation communities.

Four disjunct cordilleran plant species, which are uncommon east of the foothills:

Mountain Shooting Star (Dodecatheon conjugens): were found occasionally in fescue grasslands.

Yellow Paintbrush (Castilleja lutescens): were locally abundant in ungrazed fescue grasslands, especially in ephemeral riparian forb meadows.

Moonwort (Botrychium lunaria): found in the fescue grasslands. Most other Alberta records of this species are in the western foothills or areas further north of the Reserve.

Heart-leaved Arnica (Arnica cordifolia): although not rare or uncommon in the province, this plant occurs more commonly in the woodlands of western Alberta

A disjunct prairie species, Yampa (Perideridia gairdneri) is recorded commonly in the woods and meadows of southwest Alberta and in Cypress Hills (Cottonwood Consultants 1986, Achuff et al 1988).

Provincial Significance

Diverse areas of natural habitat. This includes plant assemblages that are among the best examples of their type in Alberta.

High species diversity for a prairie landscape in some of the community types, eg. riparian forb meadows, lightly grazed mixed-grass communities, etc. 

Extensive areas of relatively undisturbed grassland (see plates 5 and 6). This includes not only the fescue grasslands but some of the mixed grassland communitites which have not been heavily grazed.

Crowfoot Violet (Viola pedatifida). Considered rare in Alberta (Packer and Bradley 1984, Wallis et al 1987) it was found in the ungrazed fescue grassland in the northeast corner of the Reserve (Wallis and Wershler 1985). It has only been collected five times in Alberta (Moss 1983), all in the central parkland and northern fescue grassland subregions. Alberta is at the northwest limit of its range (Wallis et al 1987).

The Few-flowered Rush (Juncus confusus) has been collected in only six localities in Alberta (Moss 1983), primarily in southwest Alberta and the Cypress Hills, where it occurs in low grassland, thickets and open woods. In the Reserve, it was located in moist depressions in section 25 (Wallis and Wershler 1985).

The Small Yellow Evening Primrose (Oenothera breviflora) is rare in Alberta (Packer and Bradley 1984). It has been recorded along the sandy alkaline shore of Little Fish Lake (Wallis and Wershler 1985), and may occur within the Reserve. The only other two records of this species in Alberta were in dry slough bottoms or alkaline shores in the southeast (Wallis and Wershler 1985, Moss 1983). Its distribution in Alberta represents the northern limit of its range in North America (Wallis et al 1987).

International Significance

Extensive Rough Fescue Grassland (see plates 5 and 6). (See the discussion of this grassland under Significant Ecosystems).

\subsection{Significant Fauna}

Local Significance

Beaver dams: found only in one location in the Reserve and probably not often in the Hand Hills

$$
\text { Regional Significance }
$$

Diverse breeding bird habitats, such as the tall, dense coulee shrubbery, ungrazed fescue grasslands and woodlands.

The aspen copses have a high density of passerines species for a prairie area (see plates 5 and 9). They also provide nesting habitat for an unusually high density of Merlins, an uncommon species in the region. 

The extensive native grasslands are important habitats in the life history of a number of uncommon or rare birds of prey, including Merlins, Ferruginous Hawk, Prairie Falcons and Peregrine Falcons.

The Reserve contains key habitats for Mule Deer, White-tailed Deer and Pronghorn. These habitats include the extensive grasslands with relatively few fences, and the coulees, which function both as travel corridors and winter habitats. (Note: the Pronghorn probably do not winter in the Reserve).

The grasslands found on solonetzic soils are prime habitat for populations of Richardson's Ground Squirrel and Thirteen-lined Ground Squirrels

\title{
Provincial Significance
}

There is at least one, and perhaps two, Sharp-tailed Grouse dancing grounds.

The Reserve contains a significant breeding population of the Upland Sandpiper.

The shore of Little Fish lake is resting and feeding area for shorebirds and waterfowl, primarily used as a migratory stopover point.

The Reserve is located in a Paleontological Resource Sensitive Zone with a high rating for Quaternary fossil deposits.

\section{National Significance}

Breeding and foraging habitat for the endangered Piping Plover.

Significant populations of Baird's Sparrow. The Reserve has an uncommonly high density of this species, due mainly to the presence of undistrubed fescue grasslands.

\subsection{Significant Cultural Features}

\author{
Regional Significance
}

There are a number of archaeological features in the Reserve, notably tipi rings, stone piles and stone patterns. The Hand Hills are known to have been a favored site among native peoples.

\subsection{Significant Landscapes}

Regional Significance

The large coulees along the western boundary of the Reserve provide a unique topographical feature 

seldom found in the prairie region outside of the river valleys (see plates 11 and 12). At several points these coulees twist and turn rapidly, creating a dramatic visual landscape. They are more variable in shape than the "typical coulees" on the prairies.

\section{Provincial Significance}

Dramatic landscape: the high point of the Reserve (Thumb Hill, at the edge of the escarpment) offers spectacular views of the surrounding countryside, to an extent rarely found on the prairies(see plate 2). To the south and west can be seen the Wintering Hills and the broad valley of the Red Deer River. In exceptional conditions, the Rocky Mountains can be seen in the far distance. Stretching towards the north lies the escarpment along the western edge of the Hand Hills, with the flat plains on one side and the rolling topography of the Hand Hills on the other. To the east lies an immense sweep of seemingly endless and uninhabited prairie. Signs of human presence are, with a few small exceptions, difficult to find. 



\subsection{Sensitive Features}

The following features are those which are considered most sensitive to disturbances. Rehabilitation of these features once they are damaged would be, at best, difficult, and would require several to many years to complete.

\section{Rough Fescue Grasslands.}

As has already been discussed, fescue grasslands are sensitive to grazing, especially during the first half of the summer. Moderate to heavy grazing would destroy the fescue grassland and permit the growth of other vegetation community types. This would not only degrade the quality of the grassland ecosystem but would have ancillary effects as well. Provincially rare plant species would be quickly lost as would several disjunct cordilleran species. And the nesting habitat of many birds would be lost, in particular the Baird's Sparrow, Upland Sandpiper and Sharp-tailed Grouse.

\section{Riparian forb meadows}

The plant diversity within the ephemeral riparian forb meadows is very high for an upland prairie ecosystem. Much of the remaining prairie in Alberta has low floristic diversity, mainly due to overgrazing. The forb meadow community exists in both the grazed and ungrazed parts of the Reserve. In grazed areas flower blooms do occur but they are small in extent and low in diversity. In ungrazed areas, the diversity is much higher and the meadows are far more extensive.

\section{Shore of Little Fish Lake}

The shore of Little Fish Lake is an important nesting habitat for the endangered Piping Plover. Unfortunately, this same area is subject to several potential disturbances, all of them serious. These include:

1. the shoreline is easily accessible to recreational all-terrain vehicles,

2. raised lake levels would flood out the habitat, and

3. cattle in search of water would degrade the habitat and destroy nests.

The latter disturbance has been largely mitigated by the placement of fences around the upper shoreline of the lake, effectively preventing cattle from getting onto the flat shoreline area. However, it is always possible for cattle to find holes in fencelines or, if they find a weak spot in the fence, create the holes themselves.

\section{Reservoir-marsh.}

The reservoir-marsh is the only "semi-permanent" waterbody in the Reserve and one which is used by a large number of waterfowl and shorebirds (see plate 14). The cattle have unlimited access to this waterbody, and have the potential to seriously damage its vegetation and shoreline.

\section{Diverse breeding bird habitat}

There are several habitats which support a high level of breeding bird diversity, including the tall mixed coulee shrubbery, the aspen woodlands and the fescue grasslands. All of these habitats could be heavily impacted by cattle grazing. 



\section{Archaeological sites}

Tipi rings can be remarkably resistant to disturbances such as off-road vehicles and cattle grazing (R. Vickers, pers. comm.). However, continued damage, even by small increments, could lead to an irreplaceable loss of archaeological information. 



\subsection{Land Use and Disturbance Features}

There are not many disturbances present in the Reserve. They are presented on the Land Use and Disturbance Features map, and are discussed below.

\section{Roads}

There are a number of vehicle trails which run through the Reserve. Primary truck tracks are those which are used on a semi-regular basis, mainly by the ranchers as a means to check their herds (see plate 3). There are two such tracks; a "main north-south road" which runs through the eastern and central parts of the Reserve, and one which travels from the north gate to the corral. These trails are well-incised and in places the tire tacks are quite deep. The length of these truck tracks is $7.2 \mathrm{~km}(4.5$ miles).

Secondary truck tracks are considered those which receive little use and are not as deeply incised into the soil as the primary truck tracks. There are $13.5 \mathrm{~km}(8.1$ miles) of these trails found in many different parts of the Reserve, with several along the edge of the escarpment. Their main purpose seems to be to provide lessees occasional access to things such as dugouts, gates along fence lines, and the corral. Some of the trails along the escarpment must be used as recreational trails by allterrain vehicles as they ascend some fairly steep slopes.

Some of these secondary trails, particularly those in lush grasslands, may be easily reclaimed. Airphotos taken in 1981 clearly show two truck trails on top of the southern highlands. These same trails were not visible in 1996 photography.

The largest road in the Reserve is the fair weather dirt road which runs along the west and south side of section 25. It is used on a regular basis by the area farmers. It is $3.2 \mathrm{~km}$ (2 miles) long, half of which is entirely within the Reserve boundary.

\section{Fence lines}

There are $28.2 \mathrm{~km}$ (17.5 miles) of fence lines in the Reserve. Most of them are built along legal survey lines, separating different leases. The fence around the high-water shoreline of Little Fish Lake is $3.2 \mathrm{Km}$ ( 2.0 miles) in length and was constructed to keep cattle off the lake basin (this area being the nesting habitat of the endangered Piping Plover). Most of the fences are in good condition, especially the one along the lake shoreline.

\section{Dugouts}

There are eight dugouts in the Reserve: three in the bottom of coulees, four in ephemeral drainage channels on the grasslands and one in the reservoir-marsh (see plate 14). They vary in size from 20 X 25 meters to 20 X 55 meters (from 65 X 82 feet to 65 X 180 feet). The smallest one is next to the southwest shore of Little Fish Lake. It has no spoil piles and is evolving into a marsh. The edges are fairly well vegetated with some level muddy shoreline. It is frequently used by waterfowl and shorebirds but also receives heavy use by cattle. 

One of the dugouts is actually just a deepening of the reservoir-marsh but does not yet have the vegetative characteristics of the rest of the waterbody. Its spoil piles are two metres high and ten metres across.

The remaining six dugouts are similar in size though one is circular instead of the usual rectangle shape. Most of them are fairly new, having been constructed in 1990 or 1991. This was done in response to the fence put around Little Fish Lake to keep the cattle out of the lake basin. These dugouts all have large spoil piles, little or no aquatic vegetation and are seldom used by native wildlife. They are also exhibiting a halo effect caused by severe trampling of the vegetation in the immediate vicinity around the dugout.

\section{Corral}

The only "agricultural structure" in the Reserve, outside of the fences and dugouts, is the corral. It is located near the centre of the Reserve, along the main north-south fence line. The large corral measures 600 X 450 meters (1967 X 1476 feet), an area of 27 hectares (67 acres). Near an inside corner lies a much smaller corral. It measures 100 X 100 meters ( 328 X 328 feet), an area of one hectare $(0.4$ acres $)$. Next to this smaller corral are several pens and considerable short-length fencing.

The vegetation in the smaller corral is heavily impacted, as evidenced by the low cover of grasses and high cover of sagewort and selaginella. It does not appear as if the corral is actively used. The entire structure is probably a hold-over from the days when the Verdant Valley Ranch had the lease for much of this area and used the corral for processing. The corral is now located on the boundary between two separately owned leases.

\section{Exploratory well site}

This is a partially reclaimed exploratory well site which probably dates from the early 1980's. It is fairly small in size: 90 X 90 meters ( 295 X 295 feet), an area of 0.9 hectares ( 2.2 acres). Most of it has been revegetated by invasive and weedy species but approximately thirty percent is still bare mineral soil (for complete vegetation information, see section 7.1).

\section{Dam}

In 1966 Ducks Unlimited (Canada) constructed a weir at the mouth of the outlet channel of Little Fish Lake. It is a fixed-crest earth-fill feature 27 meters ( 89 feet) in length and 1.5 meters ( 5 feet) high, designed to maintain high water levels in the lake and prevent on-going erosion at the mouth of the channel (McIntyre 1990). Since water levels in the lake have decreased continuously since 1973 the weir no longer fulfills its original purpose. But it does help maintain water in the reservoirmarsh throughout the summer. In some years the reservoir is dry by summer's end, but most years it has at least some water in it.

\section{Right-of-way}

In the southeast part of the Reserve is a feature termed the "right-of-way". Starting at the south boundary it is the "road bed" for the main truck trail which runs up to the north end of the Reserve. When the truck trail veers off to go around the reservoir-marsh, this feature continues north and 

curves around the shoreline of Little Fish Lake, passing the eastern boundary of the Reserve just north of the lake. It is a graded surface four to five meters wide, with two meter-wide ditches running along each side. This feature may have been built in order to construct a road around Little Fish lake.

\section{Buildings}

There are only two buildings in the Reserve. One is located in the corral and is actually a small trailer which has obviously been sitting in its present location for many years. The other is a small cabin located near the bottom of the coulee in the extreme northwest of the Reserve. Neither feature is a major disturbance.

\section{Gravel pit}

There is a gravel pit located along the southern boundary of the Reserve. Like several other gravel pits also located along the Hand Hills escarpment, it is extracting material from the layer of tertiary gravels, i.e. the upper two meters of the surface. This pit is a sizeable feature: $260 \mathrm{X} 120$ meters ( $850 \times 390$ feet), an area of 3.1 hectares ( 7.7 acres).

It is an active pit and material was being removed from it during the summer of 1996. On the ground it appears that the area disturbed by pit operations is completely outside the Reserve. However, recent aerial photography has shown that part of this feature has extended to within the Reserve boundary. The end result of aggregate extraction is complete destruction of the native vegetation and the invasion of weedy, non-native plant communities.

\section{Salt blocks}

The presence of salt blocks in the Reserve was found to have a detrimental effect on the vegetation. The ground surface up to four meters from a salt block had been heavily trampled by cattle, all the vegetative cover was destroyed, and the soil surface was exposed and compacted. As has already been mentioned, some introduced grass species, such as Bromus inermis and Hordeum jubatum, have invaded into many areas of the Reserve, especially sites where the soil has been disturbed, eg. dugout spoil piles.

It is possible that too many cattle concentrated in one spot, such as at a salt lick, would allow invader plant species to gain a foothold where they would otherwise not be found. 



\subsection{Management Considerations}

Due to a number of factors, including the abundance of high quality fescue grasslands, a high level of biodiversity, and the presence of uncommon and endangered species, careful and proper management of the Reserve is a top priority. This is even more important because of the unusual situation of this particular Ecological Reserve, vis a vis the ongoing human disturbances.

\section{Cattle grazing}

The most important aspect of any management plan for this Reserve has to be the way in which it deals with the effects of cattle grazing. These effects can be widespread and very destructive if they are not properly understood and managed accordingly. The various ways in which the presence of cattle can impact the natural environment of the Reserve are discussed below.

\section{A. Fescue grasslands}

Native fescue grasslands are relatively intolerant to grazing, particularly in the first half of the summer (Wershler and Wallis 1990). Many of the floral species of fescue grasslands are not well adapted to grazing (Wallis 1990) and the grassland itself will disappear if grazed too heavily (Smoliak et al 1982). In order to maintain the fescue grassland ecosystem, a management plan must consider two factors:

1. Most of the biomass production in fescue grasslands takes place in mid-summer and reaches its peak by mid-July, a level which is maintained until September (Smoliak et al 1982). Thus, these ecosystems are very sensitive to early season grazing, and should not be grazed until at least midsummer (Wershler and Wallis 1990).

2. Light grazing, or even infrequent mowing, could help maintain the most significant plants and animals of this ecosystem (Cottonwood Consultants 1991). Moderate to heavy grazing over a long period will not.

The natural climax vegetation for most of the Reserve is either rough fescue grasslands or mixed grasslands with a significant proportion of rough fescue. It is important to maintain this natural climax cover because it is the best vegetation type in terms of resistance to drought, heavy rainfall or erosion (Webb et al 1967).

There are portions of the Reserve where the fescue grasslands have been degraded by moderate to heavy grazing, and their conversion to other vegetation communities is well under way. However, in most of these areas there still remains enough of the original components of the rough fescue community that rehabilitation is still an option (Wallis 1990). How long this option will remain viable is unknown. 



\section{B. Degradation of other grasslands}

Other grassland communities are also heavily impacted by grazing. A notable example is the mixed grassland located in the rolling topography near the southwest shore of Little Fish Lake. In wet years, this area used to experience spectacular flower blooms (Wallis 1990). With an increase in grazing pressure over the past decade, these floral events have diminished in intensity and extent such that only depleted remnants remain.

\section{Effects on wildlife}

Cattle grazing has both direct and indirect effects on the native wildlife species in the Reserve.

There are forty species of birds who breed (or are potential breeders) within the Reserve whose nests are vulnerable to destruction by cattle. The nests of these birds are either placed on the ground or, in the case of water birds, are anchored to the base of emergent vegetation or are partially freefloating. A breakdown of these forty species is given below:

$\begin{array}{lr}\text { Bird group } & \text { no. Species } \\ \text { Waterbirds } & 23 \\ \text { Upland gamebirds } & 2 \\ \text { Grassland birds } & 13 \\ \text { Raptors } & 1 \\ \text { Nighthawks } & 1\end{array}$

Cattle not only destroy the nests but can also force birds to abandon nests and eggs. Floating nests can be swamped and anchored nests can be knocked over along with the vegetation.

Cattle also damage or destroy the habitat of nesting birds. Many waterfowl prefer to nest in the close vicinity of marshes and ponds, areas which also receive very heavy use by cattle. This is especially true in the Reserve, where water sources are scarce and widely spaced.

With free access to ponds, marshes and dugouts, cattle can inflict heavy damage to the habitat of other species as well. Emergent vegetation can be easily trampled, reducing the habitat available to birds which nest along the fringe of wetlands. The steep, often vertical, shorelines characteristic of many wetlands used by cattle reduce their attractiveness to frogs and feeding shorebirds.

Heavy grazing in native grasslands have serious effects on the habitat availability and breeding success of a number of animal species, most notably the Baird's Sparrow and Upland Sandpiper. In order to maintain viable populations of these species, large areas of ungrazed fescue grasslands will be required.

Cattle also compete with deer and pronghorn for the available forage. Within the Reserve there is some separation maintained between cattle and these native mammals. Pronghorn were recorded 

most often along the southern hills, an area which is used for haying, and thus, fenced off from cattle. The deer were recorded in all areas of the Reserve but most often in the coulees and on steep slopes, where they are much more at ease with the terrain than are the cattle.

\section{Protection of riparian habitat}

Riparian environments, such as those surrounding ponds and marshes, experience disproportionate use by cattle. Livestock can damage these areas through several ways: overgrazing, soil compaction, trampling of vegetation and waste production. These effects can easily change the vegetation structure and not only reduce habitat suitability for indigenous wildlife, but also make it much easier for non-native plant species to invade (van Woudenberg nd.).

\section{E. Soil erosion}

Soil erosion in the Reserve is not a serious issue since there is very little exposed and unstable mineral soil, aside from those areas dominated by solonetzic soils. The overall erosive potential for the Hand Hills is rated as low (Geitz 1983). However, erosion could become an issue of concern if solonetzic areas are overgrazed to the extent that blowouts are not allowed to revegetate.

The other way in which soil erosion could become a problem is through the effects of haying. Current haying practices leave behind a "wind-resistant" layer of stubble, and the ground surface is rarely, if ever, broken open. Trucks used to haul out the hay follow the same tracks, thereby compacting the surface soil and making it more difficult for rapid revegetation. This situation does have the potential to start an erosional process, but the probability of it becoming a genuine concern is probably quite low.

\section{F. Maintaining biodiversity}

The Reserve has a higher level of biodiversity than do most upland prairie regions. Maintaining a variety of grazing regimes from light to moderate will ensure the continued preservation of the greatest diversity of native plant and animals. Although a heavy grazing regime may well benefit a few species, the overall effect on the ecosystem would be a negative one, as more species would be lost than gained.

It is important to conserve a high level of natural biodiversity in the Reserve for two reasons. One, it is a natural characteristic of the area, given the variety of landform types and the vegetation communities (the recent invasion of aspen copses notwithstanding). Second, diversity is a paramount component of ecosystem stability and the more stable an ecosystem, the more resistant it is to natural disasters, such as fire and drought (Tilman and Downing 1996).

\section{G. Invasion of weedy and non-native plant species}

The presence of disturbed sites in and near the Reserve has provided a source of invasive and non- 

native plant species. These disturbances include the dirt road next to Section 25 and the gravel pit.

When new disturbances arise these non-native, invasive plant species are able to quickly gain a foothold within the Reserve. The most visible example of this is the recent construction of dugouts, scattered around the Reserve. Although they are only a few years old, the spoil piles are covered with weedy plant species.

Awnless brome, an introduced species, is quite prominent in some areas of the Reserve. Many of the aspen copses in section 25 have high densities of this species, which have no doubt invaded from the nearby dirt road which runs through this part of the Reserve. Other parts of the Reserve also have small patches of this invasive grass, such as the ephemeral riparian meadows south of the reservoirmarsh.

\section{H. Access to water}

In 1990, fences were constructed around the upper shoreline of Little Fish Lake to prevent cattle from damaging the nesting habitat of the Piping Plover. As a compromise, lessees were permitted to construct dugouts within the Reserve to provide water for their cattle. In the event of a drought, or series of consecutive dry years, there would be pressure from the lesees to either dig more dugouts, put in wells or allow their cattle access to the shore of Little Fish Lake. All of these options would have negative effects on the Reserve.

\section{Haying}

According to Wallis (1990) areas within the Reserve were traditionally hayed on a four to five year rotation. During this past decade, haying was done on a three year rotation, a change also reported in recent State-of-the-Reserve reports. However, haying in some parts of the Reserve was undertaken in 1992, 1994 and 1996. Haying has a realtively strong impact on fescue grasslands, reducing their quality and, in effect, changing the vegetation community type from a fescue grassland to a mixed grassland.

\section{Protection of the Piping Plover}

The Piping Plover is an endangered species and the shoreline around Little Fish Lake is one of the best nesting habitats for this species in western North America. However, this same habitat is prime recreational habitat for humans, especially for boating, picknicking and all-terrain vehicle use (Caza 1985). This is not a major problem at the present time because water levels in the lake are so low as to preclude boating and most related activities.

However, Little Fish Lake used to be a popular recreation spot when water levels were higher. Should the lake be restored to its former size, either naturally or in man-made fashion, the habitat of the Piping Plover would be in real peril.

Piping plovers are not adaptable to disturbances on its nesting grounds. Pairs nesting on beaches used by vacationers produce less than half the number of young as pairs nesting on isolated beaches 

(Burnett et al 1989).

\section{Soil limitations}

According to Brocke (1977) the soils of the Hand Hills have limitations which restrict them to the production of perennial forage crops or use as native pasture. In most cases improvement practices for these soils are not feasible.

\section{Integration of wildlife habitat conservation practices with agricultural practices.}

Ecosystems consist of interdependent variables linked by feedback mechanisms. As such, it is not possible to manage both the natural and agricultural resources of the Reserve separately in the hopes that this method will ensure the environmental viability of the Reserve. For example, the health of both wildlife and cattle populations depend on the health of the vegetation and the quality of the water.

By integrating the conservation of natural resources into the context of continued agricultural activities, the viability of both resources can be assured. A well maintained wildlife population is a good indicator of the level of success of a sustainable agricultural program (Lord 1991).

\section{Recognition of habitat as important as the animals themselves}

The loss of wildlife is precipitated more often by the loss of adequate habitat than any other single factor. This is especially true of endangered species, whose preferred habitats are frequently as rare as the animal (Caza 1985).

By managing the rare fescue grasslands as a component of the overall environment, endangered species conservation programs stand a better chance of achieving long-term goals and stability (Caza 1985).

The same situation holds true for the endangered Piping Plover and its specific habitat requirements for nesting sites, i.e. the gravelly shore of Little Fish Lake.

\section{Controlling the spread of aspen copses}

The aspen copses in section 25 , and the one on the southern highlands, were not present in the area of the Reserve prior to the 1940's. They are now conspicuous and important parts of the landscape. Important because they are responsible for a high level of biodiversity not found on open grasslands. This includes both bird and mammal species which are not only primary users of these woodlands but also grassland species which are opportunistic users of the copses and their edge habitat.

In Alberta the parkland ecosystem developed mainly on Fescue grasslands (Smoliak et al 1982). There are several possible factors which have permitted the invasion of aspen onto fescue prairie: the presence of favourable microsites, the absence of browsing on young aspen shoots and the absence of prairie fires (Looman 1979).

Although it is desirable to maintain the biodiversity associated with these aspen copses, it must be 
recognized that they are present in the Reserve because human intervention in the natural functioning of the ecosystem has allowed them to invade. On the other hand, the aspen copses are a natural part of this ecoregion and should be treated as such.

\section{Alteration of lake levels}

In recent years there was some pressure on county officials to raise the water levels in Little Fish Lake, to accommodate recreational activities such as boating and fishing. These activities ceased after lake levels fell to very low levels, where they have remained for the last three decades. There was even a feasibility study which examined methods of having water piped in from different sources to ensure a permanent supply of water.

Raising the water levels in Little Fish Lake would destroy the critical shoreline nesting habitat of the Piping Plover, an endangered species.

\section{Fish moving into the Reserve from Little Fish Lake}

Although there are probably no fish in the Reserve at this time they could move in from Little Fish Lake. If there is a period of wet years, the lake level could rise and possibly overflow into the reservoir and nearby ponds. The type of fish most likely to gain access in this way would be Cyprinids and Sticklebacks. There is little chance that any fish larger than these two types remain in Little Fish Lake. Cyprinids and Sticklebacks would be able to survive in the ponds and marsh of the Reserve until either the wetlands dried up or froze to the bottom.

\section{Disturbance features}

Disturbances have a two-edged effect. First, they degrade or destroy natural habitat, and second, they allow non-native plant species to invade, thereby replacing a natural environment with a non-natural one.

The creation of new disturbances of any kind should be carefully considered and, if at all possible, avoided completely.

The creation of new truck tracks should not be allowed and those which exist, but are seldom used by the lessees, should be reclaimed.

Off-road vehicles should be restricted from any part of the Reserve. This is especially true of the escarpment. The combination of a spectacular view, ease of access (via the dirt road from secondary highway 573 into the gravel pit), and lots of interesting terrain, make the escarpment a prime target for users of off-road vehicles. There are several truck tracks along the edge of the escarpment already and more faint tire marks running all around the area. These disturbances not only damage the vegetation but have the potential to seriously damage the many tipi rings which, like the truck tracks, are found along the edge of the escarpment.

\section{Prevent the fescue grasslands from becoming a "habitat island"}

One of the best ways to protect the Reserve and the integrity of its resources is to prevent the Reserve 

from becoming an island of fescue grassland amidst a sea of agricultural land. The fragmentation of natural grasslands creates a situation where protected areas, such as the Reserve, are isolated from similar habitats by large stretches of man-made environments. This isolation affects immigration of wildlife and renders the remaining animals susceptible to predation, disease and human disturbance, with the end result that local extirpations can occur (Thompson 1987).

With larger blocks of natural habitat, native plant and wildlife species are better able to resist the direct and indirect effects of adjacent land uses than is possible in small areas of habitat (Graul 1980).

The relatively natural grasslands surrounding the Reserve should be considered for designation under some form of protective notation.

\section{Monitoring program}

A monitoring program should be implemented with several purposes:

1. to monitor the health of the rough fescue grassland and ensure that it does not suffer any changes which will affect its long-term viability.

2. to monitor the state of wildlife populations. Changes in the level and composition of the wildlife populations could be indicative of unseen, yet serious, changes in the overall environment of the Reserve.

3. the rough fescue grasslands in the Reserve, some of which are in near pristine conditions, should be intensively studied so as to establish a benchmark against which other fescue grasslands can be compared. This ecosystem type is becoming increasingly rare and efforts should be made today to ensure that other fescue grasslands are catalogued, assessed and protected.

The following statement illustrates the degree to which this type of scientific enquiry is viewed as an acceptable tool for verifying and helping to maintain the health of our environment:

"Agricultural and wildlife habitat managers should develop indicators to monitor and assess the state of natural resources and environmental quality on agricultural landscapes."

(Federal-Provincial Agriculture Committee on Environmental Sustainability 1990).

\section{Use of prescribed burning}

Fire has always played an important part in the growth and evolution of grassland communities. Where fire is suppressed grasslands may be replaced by other vegetation types, such as shrubdominated communities (DeGraaf et al 1991). As well, the abundance of some rare plant species may be enhanced by periodic fires (Cottonwood 1991).

The absence of fire also has effects on prairie wildlife. The suppression of fires in the U.S. midwest 

has led to a decrease in the quality of the grasslands and, subsequently, the habitat for Sharp-tailed Grouse (DeGraaf et al 1991).

The aspen copses in section 25 were not present before the 1940's. Aspen are an invader tree species, and were probably able to colonize this area due to two factors: favourable microsites for growth, and the absence of fire. It is believed that fires prevented the spread of aspen into the prairies and helped maintain the northern boundary of grasslands in central Alberta.

There have been some calls for the use of fire as a management tool to check the growth of these aspen copses (Wershler and Wallis 1990). While it is the most natural way to control tree growth, it is also the most dangerous, given the fact that the grasslands do not end at the Reserve boundary but continue, in some form, for a long distance. 



\subsection{Literature Cited}

Achuff, P.L. 1992. Natural regions, subregions and natural history themes of Alberta. A classification for protected areas management. Parks Services, Alberta Environmental Protection. $72 \mathrm{pp}$.

Achuff, P. 1994. Natural regions, subregions and natural history themes of Alberta. Prep. for Alberta Environ. Protection. 72 pp.

Achuff, P., J. Godfrey and C. Wallis. 1988. A systems planning natural history framework and evaluation system for Alberta Recreation and Parks, Vol. 2. Prep. for Alberta Recr. and Parks, Edmonton.

Acorn, J. 1993. Butterflies of Alberta. Lone Pine Publishing, Edmonton. 143pp.

Alberta Agriculture. 1996. Alberta range plants and their classification. Alberta Agriculture, Food and Rural Development. Adapted from Agdex 134/6.

Alberta Environmental Protection. 1994a. Natural regions and subregions of Alberta: summary. Alberta Environmental Protection, Edmonton. Pub. no. I/531.

Alberta Environmental Protection. 1994b. Ecological Land Survey Site Description Manual. Pub. by the Canadian Forest Service and the Alberta Land and Forest Services. 165pp.

Autenrieth, R. 1978. Guidelines for the management of pronghorn antelope. Proc. Bienn. Pronghorn Antelope Workshop 8:473-526.

Barrett, M.W. 1981. Environmental characteristics and functional significance of pronghorn fawn bedding sites in Alberta. Jour. Wildl. Manage. 45(1):120-131.

Barrett, M.W. 1982. Distribution, behavior and mortality of pronghorns during a severe winter in Alberta. Jour. Wildl. manage 46(4):991-1002.

Bird, C.D., G.J. Hilchie, N.G. Kondla, E.M. Pike and F.A.H. Sperling. 1995. Alberta Butterflies. The Provincial Museum of Alberta, Edmonton. 349pp.

Bowser, W.E. 1967. Agro-climatic areas of Alberta. Agriculture Canada. Printed by Surveys and Mapping Branch, Canada Department of Energy, mines and Resources, Ottawa.

Brocke, L.K. 1977. The Canada Land Inventory soil capability for agriculture in Alberta. Alberta Environment. 24pp. 

Brown, R.L. 1966. Response of sharp-tail breeding populations to annual changes in residual grassland cover. Forty-sixth Annual Conf of Western Assoc. of State Game and Fish Commisioners, July 12-14, 1966, Butte, Montana

Brown, D.E. 1978. Grazing, grassland cover and gamebirds. Trans. North American Wildlife and Natural Resource Conference 43:477-485.

Burnett, J.A., C.T. Dauphine Jr., S.H. McCrindle and T. Mosquin. 1989. On the brink. Endangered species in Canada. Western Producer prairie Books, Saskatoon, Saskatchewan. 192pp.

Cadman, M.D. 1985. Status report on the Loggerhead Shrike Lanius ludoviciana in Canada. Committee on the Status of Endangered Wildlife in Canada, Ottawa.

Campbell, J.D. 1974. Coal resources, Hussar-Hanna area, Alberta. Alberta Research, Edmonton. Report 74-8. 54pp.

Canada Soil Inventory. 1988. Soil landscapes of Canada - Alberta. Land Resource Research Centre, Agriculture Canada. Contribution No. 87-02. Publ. no. 5237/B.

Canada Soil Survey Committee. 1978. The Canadian system of soil classification. Research Branch, Canada Department of Agriculture, Publication 1646. 164pp.

Caza, C.L. 1985. Habitat needs of endangered species. Wildlife Habitat Canada, Ottawa. 148pp.

Chabillon, D. 1993. Tenth annual report of the advisory committee on wilderness areas and ecological reserves. Parks Services, Alberta Environmental Protection. 20pp.

Cook, F.R. 1984. Introduction to Canadian amphibians and reptiles. National museums of Canada, Ottawa. 200p.

COSEWIC. 1994. Canadian species at risk, April 1994. Committee on the Status of Endangered Wildlife in Canada. Ottawa, Ontario. 12p.

Cottonwood Consultants Ltd. 1986. The proposed Hand Hills Ecological Reserve. A biophysical review. Prep. for Alberta Recreation and Parks, Edmonton. 42pp.

Cottonwood Consultants Ltd. 1991. Environmentally significant areas in the Palliser Region. M.D. of Starland No. 47. Prep. for the Municipal District of Starland No. 47, Alberta Forestry, Lands and Wildlife, and the Palliser Regional Planning Commission. 131pp.

Coupland, R.T. 1950. Ecology of mixed prairie in Canada. Ecol. Monog. 20: 271-315. 

DeGraaf, R.M., V.E. Scott, R.H. Hamre, L. Ernst and S.H. Anderson. 1991. Forest and rangeland birds of the United States. Natural history and habitat use. U.S. Department of Agriculture, Forest Service. Agriculture Handbook 688. 625pp.

Emmel, T.C. 1975. Butterflies. Their world, their life cycle, their behavior. Alfred A. Knopf, New York. 245pp.

Energy Resources Conservation Board. 1994. Reserves of coal. Province of Alberta. 19th Edition. Pub. by Energy Resources Conservation Board, Calgary. Pub. No. ST 94-31.

FEARO (Federal Environmental Assessment Review Office). nd. Ecological land survey guidelines for environmental impact analysis. Environmental Conservation Task Force, Lands Directorate, Environment Canada. Ecological Land Classification Series, No. 13. 42pp.

Federal-Provincial Agriculture Committee on Environmental Sustainability. 1990. Growing together: report to the ministers of Agriculture. Ottawa: Agri-Food Policy Review, February, 1987.

Fish and Wildlife Division. 1990. Management plan for Pronghorn Antelope in Alberta. Wildlife Management Planning Series, Number 3. Fish and Wildlife Division, Alberta Forestry, Lands and Wildlife, Edmonton. Pub. No. T/226.

Fox, R.C. 1988. Late Cretaceous and Paleocene mammal localities of southern Alberta. Occ. Pap. Tyrell Mus. Paleon. No. 6. 38pp.

Gabert, G.M. 1986. Alberta groundwater observation-well network. Terrain Sciences Department, Alberta Research Council, Edmonton. Earth Sciences Report 86-1. 40pp.

Gietz, C.W. 1983. Erosive potential of wind in Alberta. in Alberta Climatological Association. Current climatological activity in Alberta. Proceedings of the 7th Annual Workshop, February, 1983. Pub. by the Alberta Climatological Association, Edmonton. 106pp.

Glass, D.J. (ed.). 1990. Lexicon of Canadian stratigraphy. Volume 4. Western Canada, including eastern British Columbia, Alberta, Saskatchewan and southern Manitoba. Canadian Society of Petroleum Geologists, Calgary. 772pp.

Good, J.R. and J.A. Crawford. 1978. Factors influencing use of playas in south-central Oregon. Proc. Bienn. Pronghorn Antelope Workshop, 8:182-205.

Graul, W. 1980. Grassland management practices and bird communities. Pp. 38-47 in Management of western forests and grasslands for non-game birds. United States Department of Agriculture, Forest Service General Technical Report INT-86. Ogden, Utah. 

Hand Hills Book Committee. 1968. Hand Hills Heritage. Pub. by The Hand Hills Book Committee. $579 \mathrm{pp}$.

Harmoning, A.K. 1976. White-tailed Deer dispersion and habitat utilization in central North Dakota. North Dakota Fish and Game Department, Proj. No. W-67-R-13, 14 and 15. Unpubl. report. 37pp.

Harris, S.W. 1967. Fall foods of the sharp-tailed grouse in Minnesota. Jour. Wildl. Manage 31(3):585-587.

Harvey, D.A. 1977. Lightening means in Alberta, 1972 - 1977. Alberta Forest Service, Alberta Energy and Natural Resources. ENR Report No. 138. 8pp.

Hofman, D.E. 1994. The 1991 Piping Plover census in Alberta. Pp. 43-47 in Fleming, S.P. (ed.). The 1991 international Piping Plover census in Canada. Can. Wildl. Serv. Occ. Pap. No. 82.

Johnston, A. 1961. Comparison of lightly grazed and ungrazed range in the fescue grassland of southwestern Alberta. Can. J. Plant Sci. 41: 615-622.

Jones, R.F. 1968. A board to measure cover used by prairie grouse. Jour. Wildl. Manage. 32(1):2831.

Kindschy, R., C. Sundstrom and J. Yoakum. 1978. Range/wildlife interralationships - pronghorn antelope. Proc. Bienn Pronghorn Antelope Workshop 8:216-269.

Kirsch, L. 1969. Prairie grouse and land use. Eigth Conf. Prairie Grouse Technical Council, September 9-11, 1969, Woodward Oklahoma.

Knapik, L. and D.A. Westworth. . 1984. Preliminary wildlife habitat regions/subregions of Alberta. Prep. by Pedocan Land Evaluation Ltd. for Fish and Wildlife Division, Alberta Energy and Natural Resources. 41 pp. + apps.

Kocaoglu, S.S. 1990. Physical land classification methodology. Land Information Branch, Alberta Forestry, Lands and WIldlife. $41 \mathrm{pp}$.

Long, R.J. 1970. A study of nest-site selection by island-nesting Anatids in central Alberta. M.Sc. thesis, University of Alberta. 123p.

Longley, R.W. 1967. The frequency of chinooks in Alberta. The Albertan Geographer 3: 20-21.

Looman, J. 1969. The fescue grasslands of western Canada. Vegetatio 19: 129-145.

Looman, J. 1979. The vegetation of the Canadian prairie provinces - I. An overview. Phytocoenologia 5(3): 347-366. 

Lord, J. 1991. The status of wildlife habitat in Canada. Realities and visions. Pub by Wildlife Habitat Canada, Ottawa. 102pp.

MacGregor, J.G. 1966. Peter Fidler: Canada's forgotten surveyor 1769-1822. McClelland and Stewart, Toronto. 265pp.

MacGregor, J.G. 1972. A History of Alberta. Hurtig Publishers, Edmonton. 335pp.

Martinka, C.J. 1967. Habitat relationships of white-tailed deer and mule deer in northern Montana. Jour. Wildl. Manage. 32(3):558-565.

Masterton, J.M., R.B. Crowe and W.M. Baker. 1976. The tourism and outdoor recreation climate of the prairie provinces. Meteorological Application Branch, Atmospheric Environment Service, Environment Canada. Publ. Applied Meteorology REC-1-75. 221pp.

Mattise, S.N. 1978. Effects of pasture management on sharp-tailed grouse nesting and brooding habitat in southwestern North Dakota. North Dakota State game and Fish Department, Project No. W-67-R-18. 18pp.

McIntyre, L.G. 1990. Little Fish Lake. in Mitchell, P. and E. Prepas (eds.). Atlas of Alberta lakes. The University of Alberta Press, Edmonton. 675pp.

Miller, E.E. 1972. Agriculture and settlement in southern Alberta. pp. $62-73$ in Jankunis, F. (ed). Southern Alberta. A regional perspective. The University of Alberta, Lethbridge, Alberta. 123pp.

Miller, GM. and W.D. Graul. 1980. Distribution and status of sharp-tailed grouse in North America. pp. 18-28 In Vohs, P. and F.L. Knopf (eds.) Proceedings of the Prairie Grouse Symposium. Oklahoma State University, Stillwater, OK.

Mitchell, G.J. 1980. The pronghorn antelope in Alberta. Univ. of Regina Monogr., Saskatchewan. $165 \mathrm{pp}$.

Monenco Consultants Limited. 1987. Little Fish lake regulation study. Prep. for Alberta Environment, Planing Division, Calgary.

Morrison, R.I.G., R.W. Butler, H.L. Dickson, A. Bourget, P.W. Hicklin and J.P. Goosen. 1991. Potential Western Hemisphere Shorebird Reserve Network sites for migrant shorebirds in Canada. Can. Wildl. Serv. Tech. Rep. Series No. 144. 98pp.

Moss, E.H. 1983. Flora of Alberta. 2nd edit. revised by J. Packer. Univ. of Toronto Press. Toronto. 

Moss, E. and J. Campbell. 1947. The fescue grassland of Alberta. Can. J. of Research (c) 25: 209227.

Moyles, D.L.J. 1977. A study of territory established by and movements of male sharp-tailed grouse (Pediocetes phasianellus) relative to the area. M.Sc. thesis. Univ. of Alberta, Edmonton. 91pp.

Moyles, D.L.J. 1981. Seasonal and daily use of plant communities by sharp-tailed grouse (Pediocetes phasianellus) in the parklands of Alberta. Can. Field Nat. 95(3):287-291.

Nadeau, S. (ed.). 1996. RENEW (Recovery of Nationally Endangered Wildlife) annual report $1994 / 1995$.

Nelson, J.S. and M.J. Paetz. 1992. The Fishes of Alberta. Second Edition. The University of Alberta Press, Edmonton, and The University of Calgary Press, Calgary. 437pp.

Nelson, S., D. Downing and B. Braidwood. 1988. Site selection criteria and evaluation for natural areas. Volume II. Appendices I-VII. Land Information Services Division, Alberta Forestry, Lands and Wildlife.

Nietfeld, M., J. Wilk, K. Woolnough and B. Hoskin. 1985. Wildlife habitat requirement summaries for selected wildlife species in Alberta. Fish and Wildlife Division, Alberta Energy and Natural Resources. ENR Tech. Rep. T/73.

North, M. 1976. A plant geography of Alberta. Univ. of Alberta, Dept. of Geog. Edmonton. 147 pp.

Owens, R.A. and M.T. Myres. 1973. Effects of agriculture upon populations of native passerine birds of an Alberta fescue grassland. Can. Jour. Zool. 51:697-713.

Packer, J. and C. Bradley. 1984. A checklist of the rare vascular plants in Alberta. Prov. Museum of Alberta Natural History Occ. Pap. No. 5. Alberta Culture, Edmonton.

Papirnik, P., R.H. Myrick, M. Brennand, B.L. Magill and H.S. Sandhu. 1990. A synthesis of climatological studies in Alberta from 1975 to 1986. Alberta Department of the Environment, Edmonton, Alberta. 110pp.

Pawluk, S. and L.A. Bayrock. 1969. Some characteristics and physical properties of Alberta tills. Research Council of Alberta, Edmonton. Bulletin 26. 72pp.

Pashley, D. 1996. Watch list. National Audubon Society Field Notes 50 (2): 129-134. 

Pepper, G.W. 1972. The ecology of sharp-tailed grouse during spring and summer in the aspen parklands of Saskatchewan. Saskatchewan Department of Natural Resources, Wildlife Report Number 1.56pp.

Peters, T.W. 1981. Solonetzic soils of Alberta. Map, scale 1: 1,000,000. Agric. Canada Soil Survey, Alberta Inst. of Pedology M-80-4.

Pettapiece, W.W. and R.G. Eilers. 1990. Soil salinity - Alberta. Land Resource Research Centre, Agriculture Canada. Contribution no. 87-13. Publ. no. 5262/B.

Phillips, D. 1990. The Climates of Canada. Supply and Services Canada, Ottawa. 176pp.

Pyle, R.M. 1984. The Audubon Society handbook for butterfly watchers. Charles Scribner's Sons, New York. 274pp.

Roberts, W. 1981. What happened to the Leopard Frogs? Alberta Naturalist 11(1): 1-4.

Roberts, W. 1992. Declines in amphibian populations in Alberta. pp. 14-16 in Bishop, C.A. and K.E. Pettit (eds.). Declines in Canadian amphibian populations: designing a national monitoring strategy. Canadian Wildlife Service Occ. Pap. No. 76. 120pp.

Rowe, J.S. 1979. Revised working paper on methodology/philosophy of ecological land classification in Canada. Pp. 23-30 in Rubec, C.D.A. (ed.). Applications of ecological (biophysical) land classification in Canada. Proceedings of the second meeting, Canada Committee on Ecological (Biophysical) Land Classification, April, 1978, Victoria, B.C. 396pp.

Russell, A.P. and A.M. Bauer. 1993. The Amphibians and Reptiles of Alberta. A Field Guide and Primer of Boreal Herpetology. The University of Calgary Press, Calgary, and The University of Alberta Press, Edmonton. 264pp.

Russell, L.S. 1958. A horse Astragalus from the Hand Hills conglomerate of Alberta. Nat. Mus. Can. Natural Hist. Pap. 1. 3pp.

Schmidt, A.P. 1981. Wetland habitat inventory of the Kindersley (72-N) map area. Wildlife Technical Report 81-12. Wildlife Branch, Department of Tourism and Renewable Resources. 107pp.

Sealy, S.G. and D.A. Sexton. 1976. Movements and habitat use by female sharp-tailed grouse. Mantoba-Wildlife Research Progress Report.

Semenchuk, G.P. 1992. The Atlas of Breeding Birds of Alberta. Federation of Alberta Naturalists, Edmonton. 391pp. 

Smith, A.G. 1971. Ecological factors affecting waterfowl production in the Alberta parklands. U.S. Dept. of the Interior, Fish and Wildlife Service Res. publ. No. 98. 49p.

Smith, H.C. 1993. Alberta Mamals. An Atlas and Guide. The Provincial Museum of Alberta, Edmonton. 238pp.

Smoliak, S., M.R. Kilcher, R.W. Lodge and A. Johnston. 1982. Management of prairie rangeland. Agriculture Canada, Ottawa. Pub. No. 1589/E.

Stelfox, H.A. 1979. Terrestrial wildlife habitat inventory of the Weyburn (62E) - Varden (62F) map area. Wildl. Tech. Report 79-6. Saskatchewan Tourism and Renewable Resources.

Storer, J.E. 1978. Tertiary sands and gravels in Saskatchewan and Alberta: correlation of mammalian faunas. Pp 595-602 in Stelck, C.R. and B.D.E. Chatterton (eds.), Western and Arctic Canadian Biostratigraphy. Geological Association of Canada Special Paper 18. 602pp.

Strong, W.L. and K.R. Leggat. 1992. Ecoregions of Alberta. Land Information Services Division, Alberta Forestry, Lands and Wildlife. 59pp.

Thomas, J.W. 1979. Wildlife habitats in managed forests in the Blue Mountains of Oregon and Washington. U.S. Dept. of Agriculture, Forest Service. Agriculture Handbook 553.

Thompson, I.D. 1987. The myth of integrated wildlife/forestry management. Queen's Quarterly 94(3):609-621.

Tilman, D. and J.A. Downing. 1996. Biodiversity and stability in grasslands. Nature 367:363-365.

Toogod, J.A. and R.R. Cairns (eds.). 1973. Solonetzic soils technology and management. Bulletin B-73-1. Department of Extension, university of Alberta, Edmonton. 92pp.

Vanden Berg, A. and D.H. Lennox. 1969. Groundwater chemistry and hydrology of the Hand Hills Lake area, Alberta. Research Council of Alberta, Edmonton. Report 69-1. 49pp.

van Woudenberg, A.M.. nd. Grazing impacts on the biodiversity of grassland riparian ecosystems. Fourth Prairie Conservation Workshop.

Wallis, C. 1990. Hand Hills fescue grassland - biophysical overview. Prep. by Cottonwood Consultants Ltd. for The Nature Conservancy of Canada, Calgary, Alberta. 13pp.

Wallis, C. 1991. Environmentally significant areas of the lower Red Deer river. Prep. by Cottonwood Consultants Ltd. for Alberta Forestry, Lands and Wildlife, Edmonton. 66pp. 

Wallis, C. and C. Wershler. 1985. Little Fish Lake Resource Assessment for Ecological Reserves Planning in Alberta. Prep. by Cottonwood Consultants Ltd. for Public Lands Division, Alberta Energy and Natural Resources, Edmonton, ENR Tech. Rep. T/82. 78pp.

Wallis, C., C. Bradley, M. Fairbarns and V. Loewen. 1987. The rare flora of Alberta. Vol. 3. Species summary sheets. Alberta Forestry, Lands and Wildlife. Edmonton.

Wallmo, O.C. 1978. Mule and black-tailed deer in North America. Wildl. Manage. Instit., University of Nebraska Press.

Watson, A., P.E.S. Whalley and W.D. Duckworth. 1975. The dictionary of butterflies and moths in color. Exeter Books, New York. 296pp.

Webb, R., A. Johnston and J.D. Soper. 1967. The prairie world. pp. 93-115 in Hardy, W.G. (ed.). Alberta. A Natural History. Hurtig Publishers, Edmonton. 343pp.

Weller, M.W., B.H. Wingfield and J.B.Low. 1958. Effects of habitat deterioration on bird populations of a small Utah marsh. Condor 60:220-226.

Wershler, C.R. 1989. Piping Plover surveys in Alberta, 1989. Unpublished report prepared for Alberta Forestry, Lands and Wildlife, Edmonton. 10pp.

Wershler, C.R. 1990. Status of the Baird's Sparrow in Alberta, 1989. Prep. by Sweetgrass Consultants for World Wildlife Fund Canada (Prairie For Tomorrow) and Alberta Fish and Wildlife, Edmonton.

Wershler, C. and C. Wallis. 1986. Lost River significant features assessment. Prep. by Sweetgrass Consultants Ltd. for Public Lands Division, Alberta Forestry, Lands and Wildlife. 54pp.

Wershler, C. and C. Wallis. 1990. Survey and evaluation of Northern Fescue Grassland in Alberta 1989. Prep. by Sweetgrass Consultants Ltd., Calgary, Alberta, for Alberta Forestry, Lands and Wildlife, Edmontor 37pp.

Wiens, J.A. and M.I. Dyer. 1975. Rangeland avifaunas: their composition, energetics and role in the ecosystem. In Proceedings, a symposium on management of forest and range habitats for nongame birds. May 5-9, 1975, Tuscon, Arizona.

Wiken, E. 1986. Terrestrial ecozones of Canada. Lands Directorate, Environment Canada. Ecological Land Classification Series, No. 19. 26pp.

Wildlife Management Branch. 1991. The status of Alberta wildlife. Fish and Wildlife Division, Alberta Forestry, Lands and Wildlife, Edmonton. 49pp. 

Wroe, R.A., S. Smoliak, B.W. Adams, W.D. Willms and M.L. Anderson. 1988. Guide to range condition and stocking rates for Alberta grasslands - 1988. Alberta Agriculture, Lacombe. 33pp.

Yde, C.A. 1977. Distribution and movements of sharp-tailed grouse during spring and summer in relation to rest-rotation grazing. Montana Game and Fish Department. P-R Proj. Rep., W-120-R. $70 \mathrm{pp}$.

Yoakum, J.D. 1978. Managing rangelands for the American pronghorn antelope. Proc. Bienn. Pronghorn Antelope Workshop 8:321-336. 



\subsection{Personal Communications}

The following people kindly gave of their time and expertise to provide additional information to this study.

Russ Wells - Landscape ecologist, Resource Data Division, Alberta Environmental Protection.

Peter Miloh - Paleontologist, Provincial Museum of Alberta.

Rod Vickers - Archaeologist, Provincial Museum of Alberta. 



\section{Appendices}

The remainder of this report consists of the following appendices:

Appendix I Appendix II Appendix III Appendix IV Appendix V Appendix VI Appendix VII Appendix VIII Appendix IX Appendix X
Vegetation/Ecosite data sheets

Annotated list of plant species

Annotated list of the fish

Annotated list of the herpetofauna

Annotated list of the birds

Annotated list of the mammals

Annotated list of the butterflies

Reserve history and administrative land use

Plates

Maps and air photos 



\section{Appendix I Vegetation - Ecosite Data Sheets}

The ecological land classification of the Reserve was based on a hierarchical system which divided the land into units of recurring landforms, soils and vegetation. These land units were analyzed and mapped at a scale of 1:10,000, the finest level generally used for ecosite analysis.

To provide a more comprehensive picture of the biophysical attributes of the Reserve, data sheets were prepared based on this ecosite analysis. The defining basis for these data sheets is vegetation.

Ecosites with a similar vegetation community were grouped together and the modal ecological and environmental attributes described. Variation about this mode certainly occurs, due to two factors:

1. ecosystems are dynamic assemblages which are constantly adjusting to changing environmental conditions, and

2. even at $1: 10,000$, a seemingly pure vegetation community can contain elements of other communities, due to small-scale variations in topography, soils and effects of cattle grazing.

The vegetation-ecosite data sheets are placed in the same order as are the vegetation community types in section 7.1. This order is given below:

\section{Fescue Grassland}

Rough Fescue

\section{Mixed Grassland}

Rough Fescue - Western Porcupine Grass

Rough Fescue - Green Needle Grass - Forbs

Rough Fescue - June Grass - Juniper - Forbs

Western Porcupine Grass - Rough Fescue - Forbs

June Grass - Sedge - Sagewort - Selaginella

Needle and Thread - Sedge - Selaginella

Gumweed - Bluegrass - Foxtail Barley

\section{Shrubbery}

Buckbrush - Rough Fescue

Rose - Rough Fescue - Forb

Silverberry - Rough Fescue - Hooker's Oat Grass

Salix/Saskatoon - Rough Fescue/Bluegrass

Buffaloberry - Rough Fescue 



\section{Woodlands}

Aspen - Buckbrush - Forb - Wheat Grass

Aspen - Awnless Brome

Poplar - Buckbrush - Wheat Grass

\section{Ephemeral Riparian Meadows}

Mixed-Grass - Forb

Rough hair Grass - Sedge - Forb

\section{Wetlands}

Bluegrass - Rough Hair Grass - Cinquefoil

Sedge - Rough Hair Grass

Sedge - Wire Rush 



\section{Vegetation/Ecosite Data Sheet:}

\section{Rough Fescue community}

Vegetation type:

Successional status:

Range condition:

Expected climax community:

Nutrient regime:

Mineral soil exposure:

\section{Dominant species}

Graminoids

Rough fescue

\section{Secondary species}

\section{Graminoids}

Western porcupine grass

Hooker's oat grass

Western wheat grass

Slender wheat grass

June grass

Blunt sedge

Hooker's oat grass

$\underline{\text { Shrubs }}$

Buckbrush

Prairie rose

\section{$\underline{\text { Forbs }}$}

Wild vetch

Northern bedstraw

Shining arnica

Early yellow locoweed

Field mouse-ear chickweed

Harebell

\author{
Fescue Grassland \\ climax \\ excellent \\ fescue grassland \\ mesotrophic \\ none
}

Mean foliar cover

79
Stipa curtiseta

Helictotrichon hookeri

Agropyron dasystachyum

Agropyron trachycaulum

Koeleria macrantha

Carex obtusata

Helictotrichon hookeri

Symphoricarpos occidentalis

Rosa arkansana

Vicia americana

Galium boreale

Arnica fulgens

Oxytropis sericea

Cerastium arvense

Campanula rotundifolia 

Golden bean

Prairie onion

Gaillardia

Three-flowered avens

Harebell

Stiff yellow paintbrush

Aster

Early yellow locoweed

Pasture sagewort

Prairie sagewort

Missouri milk vetch

Blue-eyed grass

Milk vetch

Prairie crocus

Prairie selaginella

Death carnas
Thermopsis rhombifolia

Allium textile

Gaillardia aristata

Geum triflorum

Campanula rotundifolia

Castilleja lutescens

Aster ericoides

Oxytropis sericea

Artemesia frigida

Artemesia ludoviciana

Astragalus missouriensis

Sisyrinchium montanum

Astragalus flexuosus

Anemone patens

Selaginella densa

Zygadenus venenosus

\section{Environmental Characteristics}

Landform:

Soil:

Parent material:

Texture:

Drainage:

Moisture regime:

Soil pH - B horizon:

Slope:

Aspect:

Slope position:

Depth to carbonates: variable: level to undulating and inclined uplands; level plains mostly Orthic Black and Orthic Dark Brown Chernozems; occasionally Gleyed Eluviated Black Chernozems and Dark Brown Solods

ranges from morainal veneers to glaciofluvial blankets

variable; generally $\mathrm{SiCL}$ and $\mathrm{L}$ over $\mathrm{gS}$ to $\mathrm{C}$ moderately well

mesic

6.0 to 7.0

low angled slopes, generally less than $5 \%$

variable

generally upland areas

30 to $50 \mathrm{~cm}$ 



\section{Vegetation/Ecosite Data Sheet:}

\section{Rough Fescue - Western Porcupine community}

Vegetation type:

Successional status:

Range condition:

Expected climax community:

Nutrient regime:

Mineral soil exposure:

\section{Dominant species}

Graminoids

Rough fescue

Western porcupine grass

\author{
Mixed Grassland \\ climax \\ good to excellent \\ Rough fescue-Western Porcupine \\ mesotrophic \\ none; occasional surface stones
}

Mean foliar cover

Festuca scabrella

Stipa curtiseta

15

\section{Secondary species}

Graminoids

Hooker's oat grass

Interior bluegrass

June grass

Western wheat grass

Blue grama

Canby bluegrass

Blunt sedge

Low sedge

Western wheat grass

Forbs

Golden bean

Prairie crocus

Club-moss

Wild vetch

Field mouse-ear chickweed

Early yellow locoweed

Stiff yellow paintbrush

Shining arnica

Missouri milk vetch
Helictotrichon hookeri

Poa interior

Koeleria macrantha

Agropyron smithii

Bouteloua gracilis

Poa canbyi

Carex obtusata

Carex stenophylla

Agropyron dasystachyum

Thermopsis rhombifolia

Anemone patens

Selaginella densa

Vicia americana

Cerastium arvense

Oxytropis sericea

Castilleja lutescens

Arnica fulgens

Astragalus missouriensis 

Blue-eyed grass

False dandelion

Golden aster

Stiff yellow paintbrush

Missouri milk vetch

Prairie onion

Moonwort

Seaside buttercup

Milk vetch

Pale comandra

Prairie sagewort

Richardson's alumroot

Northern buttercup

Gaillardia

Northern bedstraw

Pasture sagewort

Rock cress

Field mouse-ear chickweed

Moss phlox

Tufted felabane

Harebell

Low everlasting

Common yarrow

Cinquefoil
Sisyrinchium montanum

Agoseris glauca

Heterotheca villosa

Castilleja lutescens

Astragalus missouriensis

Allium textile

Botrychium lunaria

Ranunculus cymbalaria

Astragalus flexuosus

Comandra umbellata

Artemisia ludoviciana

Heuchera richardsonii

Ranunculus pedatifidus

Gaillardia aristata

Galium boreale

Artemisia frigida

Arabis hirsuta

Cerastium arvense

Phlox hoodii

Erigeron caespitosus

Campanula rotundifolia

Antennaria aprica

Achillea millefolium

Potentilla pennsylvanica

\section{Environmental Characteristics}

Landform:

Soil:

Parent material:

Texture:

Drainage:

Moisture regime:

Soil pH - B horizon:

Slope:

Aspect:

Slope position:

Depth to carbonates: variable; uplands

Orthic Dark Brown Chernozem; occasionally Eluviated Dark Brown

Chernozem

morainal veneers

$\mathrm{CL}$ to $\mathrm{SiCL}$ over $\mathrm{SiC}$ to $\mathrm{gC}$

moderately well

submesic to mesic

6.5 to 7.0

level to less than $5 \%$

NA

variable; usually uplands

$--$ 



\section{Vegetation/Ecosite Data Sheet:}

\section{Rough Fescue - Green Needle Grass - Forbs community}

Vegetation type:

Successional status:

Range condition:

Expected climax community:

Nutrient regime:

Mineral soil exposure:

\author{
Mixed Grassland \\ edaphic climax \\ good \\ edaphic climax \\ mesotrophic \\ $5 \%$
}

\section{Dominant species}

Mean foliar cover

Graminoids

Rough fescue

Green needle grass

Fesctuca scabrella

Stipa viridula

Forbs

Prairie sagewort

Artemisia ludoviciana

\section{Secondary species}

Graminoids

June grass

Koeleria macrantha

Western porcupine grass

Stipa curtiseta

Northern wheat grass

Agropyron dasystachyum

Sand grass

Calamovilfa longifolia

Blue grama

Bouteloua gracilis

Sand grass

Calamovilfa longifolia

\section{Forbs}

Golden bean

Three-flowered avens

Bastard toadflax

Prairie groundsel

Prickly-pear

Golden aster

Narrow-leaved puccoon

Ground-plum

Thermopsis rhombifolia

Geum triflorum

Comandra umbellata

Senecio canus

Opuntia polyacantha

Heterotheca villosa

Lithospermum incisum Astragalus crassicarpus

Loose-flowered milk vetch 

Wild vetch

White cinquefoil

Scarlet butterflyweed

Wormseed mustard

Low everlasting

Long-fruited wild parsley

Perennial lupine

Prairie onion

Moss phlox

Wild blue flax

Goat's-beard

Common yarrow

Northern bedstraw

Field mouse-ear chickweed

Stiff yellow paintbrush

Blue-eyed grass

$\underline{\text { Shrubs }}$

Buckbrush

Saskatoon

Prairie rose
Vicia americana

Potentilla arguta

Gaura coccinea

Erysimum cheiranthoides

Antennaria aprica

Lomatium macrocarpum

Lupinus argenteus

Allium textile

Phlox hoodii

Linum lewisii

Tragopogon dubius

Achillea millefolium

Galium boreale

Cerastium arvense

Castilleja lutescens

Sisyrinchium montanum

Symphoricarpos occidentalis

Amelanchier alnifolia

Rosa arkansana

\section{Environmental Characteristics}

Landform:

Soil:

Parent material:

Texture:

Drainage:

Moisture regime:

Soil pH - B horizon:

Slope:

Aspect:

Slope position:

Depth to carbonates: escarpment slopes

Gleyed Dark Brown Chernozem

morainal veneer over bedrock

gSiL over C

moderately well

submesic

6.5

$26 \%$

south and southwest

upper to lower slopes of the escarpment $30 \mathrm{~cm}$ 



\section{Vegetation/Ecosite Data Sheet:}

\section{Rough Fescue - June Grass - Juniper - Forbs}

Vegetation type:

Successional status:

Range condition:

Expected climax community:

Nutrient regime:

Mineral soil exposure:

\author{
Mixed Grassland \\ edaphic climax \\ good \\ edaphic climax \\ mesotrophic \\ $30 \%$ to $35 \%$
}

\section{Dominant species}

Mean foliar cover

Graminoids

Rough fescue

June grass

\section{Secondary species}

Graminoids

Western porcupine grass

Green needle grass

Northern wheat grass

Blue grama

Low sedge

Interior bluegrass

\section{Forbs}

Golden bean

Yellow umbrella-plant

Tufted fleabane

Alpine hedysarum

Bastard toadflax

Wild blue flax

Prairie onion

Gaillardia

Scarlet butterflyweed

Long-fruited wild parsley

Missouri goldenrod

Northern bedstraw
Festuca scabrella

Koeleria macrantha
20

10
Stipa curtiseta

Stipa viridula

Agropyron dasystachyum

Bouteloua gracilis

Carex stenophylla

Poa interior

Thermopsis rhombifolia

Eriogonum flavum

Erigeron caespitosus

Hedysarum alpinum

Comandra umbellatta

Linum lewisii

Allium textile

Gaillardia aristata

Gaura coccinea

Lomatium macrocarpum

Solidago missouriensis

Gallium boreale 

Common yarrow

Harebell

Milk vetch

Moss phlox

Narrow-leaved hawkweed

Prairie crocus

Low milkweed

Low everlasting

Cut-leaved anemone

Three-leaved avens

Wild strawberry

Western wood lily

Richardson's alumroot

Canada anemone

Pasture sagewort

Thistle

Blunt-leaved sandwort

$\underline{\text { Shrubs }}$

Buckbrush

Saskatoon

Canada buffaloberry

Silverberry
Achillea millefolium

Campanula rotundifolia

Astragalus tenellus

Phlox hoodii

Hieracium umbellatum

Anemone patens

Asclepsis ovalifolia

Antennaria aprica

Anemone multifida

Geum triflorum

Fragaria virginiana

Lilium philadelphicum

Heuchera richardsonii

Anemone canadensis

Artemisia frigida

Cirsium undulatum

Moehringia lateriflora

Symphoricarpos occidentalis

Amelanchier alnifolia

Shepherdia canadensis

Elaeagnus commutata

\section{Environmental Characteristics}

Landform:

Soil:

Parent material:

Texture:

Drainage:

Moisture regime:

Soil pH - B horizon:

Slope:

Aspect:

Slope position:

Depth to carbonates: coulee slopes

Orthic Regosol

glaciofluvial

$\mathrm{C}$ over SiCL to C

moderately well

subxeric

8.0

$35 \%$ to $50 \%$

south; generally east and west; occasionally north aspects on lower angled slopes.

upper to lower coulee slopes

$5 \mathrm{~cm}$ to $10 \mathrm{~cm}$ 



\section{Vegetation/Ecosite Data Sheet:}

\section{Western Porcupine Grass - Rough Fescue - Forbs}

Vegetation type:

Successional status:

Range condition:

Expected climax community:

Nutrient regime:

Mineral soil exposure:

\section{Dominant species}

Graminoids

Rough Fescue

Western porcupine grass

Forbs

Prairie club-moss

\section{Secondary species}

\section{Graminoids}

Hooker's oat grass

Blunt sedge

Low sedge

June grass

Northern wheat grass

Wire rush

Slender wheat grass

Interior bluegrass

Blue grama

Forbs

Pasture sagewort

Prairie crocus

Low everlasting

Golden bean

Dandelion

Wild vetch

\author{
Mixed Grassland \\ seral \\ good to fair \\ Rough fescue \\ mesotrophic \\ none
}

\section{Mean foliar cover}

Festuca scabrella

11

Stipa curtiseta

17

Salaginella densa
Helictotrichon hookeri

Carex obtusata

Carex stenophylla

Koeleria macrantha

Agropyron dasystachyum

Juncus balticus

Agropyron trachycaulum

Poa interior

Bouteloua gracilis

Artemisia densa

Anemone patens

Antennaira aprica

Thermopsis rhombifolia

Taraxacum officinale

Vicia americana 

Common Yarrow

Shining arnica

Field mouse-ear chickweed

Aster

Northern bedstraw

False dandelion

Prairie sagewort

Golden aster

Gaillardia

Heart-leaved buttercup

Fleabane

Three-flowered avens

Stiff yellow paintbrush

Moss phlox

Tufted fleabanne

Prairie parsley

Early yellow locoweed

Richardson's alumroot

Prairie onion

Shining arnica

Death camas

$\underline{\text { Shrubs }}$

Common wild rose

Prairie rose
Achillea millefolium

Arnica fulgens

Cerastium arvense

Aster sp.

Galium boreale

Agoseris glauca

Artemisia ludoviciana

Heterotheca villosa

Gaillardia aristata

Ranunculus cardiophyllus

Erigeron compositus

Geum triflorum

Castilleja lutescens

Phlox hoodii

Erigeron caespitosus

Lomatium foeniculaceum

Oxytropis sericea

Heuchera richardsonii

Allium textile

Arnica fulgens

Zigadenus venenosus

Rosa woodsii

Rosa arkansana

\section{Environmental Characteristics}

Landform:

Soil:

Parent material:

Texture:

Drainage:

Moisture regime:

Soil pH - B horizon:

Slope:

Aspect:

Slope position:

Depth to carbonates: level to slightly rolling plains

Eluviated Dark Bown Chernozem

morainal veneers and blankets

$\mathrm{CL}$ to $\mathrm{SiL}$ over $\mathrm{SiC}$ to $\mathrm{gS}$

moderately well

submesic

7.0 to 8.0

level

NA

NA 



\section{Vegetation/Ecosite Data Sheet:}

\section{June Grass - Sedge - Sagewort - Selaginella}

Vegetation type:

Successional status:

Range condition:

Expected climax community:

Nutrient regime:

Mineral soil exposure:
Mixed Grassland

seral

fair to poor

Rough fescue - Western porcupine mesotrophic

$3-5 \%$

\section{Dominant species}

Mean foliar cover

Graminoids

June grass

Low sedge

Blunt sedge

Western porcupine grass

Koeleria macrantha

8

Carex stenophylla

8

Carex obtusata

11

Stipa curtiseta

Forbs

Pasture sagewort

Artemisia frigida

10

Prairie selaginella

Selaginella densa

\section{Secondary species}

\section{Graminoids}

Interior bluegrass

Poa interoir

Rough fescue

Festuca scabrella

Blue grama

Bouteloua gracilis

Interior bluegrass

Poa interior

Western wheat grass

Agropyron dasystachyum

Forbs

Prairie crocus

Low everlasting

Tufted fleabane

Field mouse-ear chickweed

Common yarrow

Golden aster

Anemone patens

Antennaria aprica

Erigeron caespitosum

Cerastium arvense

Achillea millefolium

Heterotheca villosa 

Prairie onion

Three-flowered avens

False dandelion

Wornseed mustard

Golden bean

Cinquefoil

Gaillardia

Bastard toadflax

Low whitlow-wort

Cinquefoil

Heart-leaved buttercup

Fairy candelabra

Dandelion

Three-flowered avens

Wild vetch

$\underline{\text { Shrubs }}$

Common wild rose
Allium textile

Geum triflorum

Agoseris glauca

Erysimum cheiranthoides

Thermopsis rhombifolia

Potentilla pennsylvanica

Gaillardia aristata

Comandra umbellata

Paronychia sessiliflora

Potentilla hippiana

Ranunculus cardiophyllus

Androsace septentrionalis

Taraxacum officinale

Geum triflorum

Vicia americana

Rosa woodsii

\section{Environmental Characteristics}

Landform:

Soil:

Parent material:

Texture:

Drainage:

Moisture regime:

Soil pH - B horizon:

Slope:

Aspect:

Slope position:

Depth to carbonates: level to slightly undulating glaciofluvial material

Orthic Dark Brown Chernozem; occasionally Gleyed Eluviated Dark Brown Chernozem

glaciofulvial veneers and blankets

gLS/gs; some areas of Sil/C

well to moderately well

subxeric to mesic; usually submesic

7.0 to 8.0

level to $2 \%$

NA

NA

NA 

7. Vegetation/Ecosite Data Sheet:

Needle and Thread Grass - Sedge - Selaginella:

Vegetation type:

Successional status:

Range condition:

Expected climax community:

Nutrient regime:

Mineral soil exposure:

\section{Dominant species}

Graminoids

Needle-and-thread grass

Blunt sedge

June grass

Forbs

Prairie selaginella

\section{Secondary species}

Graminoids

Blue grama

Rough fescue

Hooker's oat grass

Western wheat grass

Slender wheat grass

Forbs

Prairie crocus

Tufted fleabane

Pasture sagewort

Golden bean

Pale comandra

Wild vetch

Milk vetch

Cinquefoil

Cinquefoil

\author{
Mixed Grassland \\ climax \\ fair \\ mesotrophic \\ $2 \%$
}

Mean foliar cover

Stipa comata

Carex obtusata

Koeleria macrantha

16

7

20

Selaginella densa

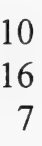

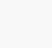



Low whitlow-wort

Clustered broom-rape

Scarlet mallow

Prairie groundsel

Milk vetch
Paronychia sessiflora

Orobanche fasciculata

Sphaeralcea coccinea

Senecio canus

Astragalus dasyglottis

\section{Environmental Characteristics}

Landform:

Soil:

Parent material:

Texture:

Drainage:

Moisture regime:

Soil pH - B horizon:

Slope:

Aspect:

Slope position:

Depth to carbonates: level portions of southern highlands

Orthic Dark Brown Chernozems

morainal veneer over bedrock

$\mathrm{gSiCL} / \mathrm{CL}$

moderately well

mesic

6.0

level

NA

NA

$32 \mathrm{~cm}$ 

8. Vegetation/Ecosite Data Sheet:

\section{Gumweed - Bluegrass - Foxtail Barley}

Vegetation type:

Successional status:

Range condition:

Expected climax community:

Nutrient regime:

Mineral soil exposure:
Mixed Grassland edaphic climax poor to fair edaphic climax mesotrophic $30 \%$

\section{Dominant species}

\section{Graminoids}

Foxtail barley

Early bluegrass

Hordeum jubatum

Poa cusickii

Forbs

Gumweed

Grindelia squarrosa

\section{Secondary species}

Graminoids

Western wheat grass

Salt grass

Agropyron smithii

June grass

Distichlis stricts

Koeleria macrantha

Forbs

Saline plantain

Plantago eriopoda

Common yarrow

Achillea millefolium

Silverweed

Potentilla anserina

Pasture sagewort

Artemisia frigida

Tufted fleabane

Erigeron caespitosus

Low everlasting

Antennaria aprica

Milk vetch

Cut-leaved anemone

Anemone multifida 



\section{Environmental Characteristics}

Landform:

Soil:

Parent material:

Texture:

Drainage:

Moisture regime:

Soil pH - B horizon:

Slope:

Aspect:

Slope position:

Depth to carbonates: level glaciofluvial plain

Gleyed Solonetzic Dark Brown Chernozem glaciofluvial

$\mathrm{SiL} / \mathrm{SiC}$

moderately well

subxeric

7.0

na

na

na

$41 \mathrm{~cm}$ 

9. Vegetation/Ecosite Data Sheet:

\section{Buckbrush - Rough Fescue community}

Vegetation type:

Successional status:

Range condition:

Expected climax community:

Nutrient regime:

Mineral soil exposure:
Shrubbery

seral

fair

mesotrophic

none

\section{Dominant species}

Mean foliar cover

$\underline{\text { Shrubs }}$

Buck brush

Symphoricarpos occidentallis

30

Graminoids

Rough fescue

Festuca scabrella

25

\section{Secondary species}

$\underline{\text { Shrubs }}$

Wild rose

Rosa woodsii

Graminoids

Awnless brome

Bromus inermis

Forbs

Common Yarrow Achillea millefolium

Prairie sagewort Artemisia ludoviciana

Field mouse-ear chickweed Cerastium arvense

Sweet-scented bedstraw Galium triflorum

White cinquefoil

Potentilla arguta 



\section{Environmental Characteristics}

Landform:

shallow drainage channels

Soil:

usually Orthic Black Chernozem; occasionally Eluviated Dark Brown Chernozem, Dark Brown Solod or Dark Brown Solodized Solonetz.

Parent material: glaciofluvial and morainal

Texture:

$\mathrm{L}$ to $\mathrm{L}$ over $\mathrm{C}$ to $\mathrm{gSC}$

Drainage:

moderately well

Moisture regime:

mesic

Soil pH - B horizon:

5.5 to 6.0

Slope:

$1 \%$ to $2 \%$

Aspect:

NA

Slope position:

level to slightly depressional

Depth to carbonates: 

10. Vegetation/Ecosite Data Sheet:

\section{Rose - Rough Fescue - Forb}

Vegetation type:

Successional status:

Range condition:

Expected climax community:

Nutrient regime:

Mineral soil exposure:

\author{
Shrubbery \\ climax \\ good \\ Rose - Rough fescue - Forb \\ mesotrophic \\ $2 \%$ to $4 \%$
}

\section{Dominant species}

Mean foliar cover

$\underline{\text { Shrub }}$

Common wild rose

Rosa woodsii

14

Graminoid

Rough fescue

Festuca scabrella

$\underline{\text { Forb }}$

Alpine hedysarum

Three-flowered avens

Northern bedstraw

Hedysarum alpinum

Geum triflorum

Galium boreale

\section{Secondary species}

$\underline{\text { Shrub }}$

Buckbrush

Saskatoon

Creeping juniper

Canada buffaloberry

Prairie rose

Choke cherry

Northern gooseberry

Beaked willow

Graminoid

Green needle grass

Hooker's oat grass

June grass
Symphoricarpos occidentale

Amelanchier alnifolia

Juniperus horizontale

Shepherdia canadensis

Rosa arkansana

Prunus virginiana

Ribes oxyacanthoides

Salix bebbiana

Stipa viridula

Helictotrichon hookeri

Koeleria macrantha 

Western wheat grass

Slender wheat grass

Sprengel's sedge

Smooth brome

Sedge

Sedge

Bluegrass

Bluegrass

Forb

Golden bean

Wild strawberry

Richardson's alumroot

Wild vetch

Stiff yellow paintbrush

Slender blue beardtongue

Prairie groundsel

Gaillardia

White cinquefoil

Blunt-leaved sandwort

Canada goldenrod

Cut-leaved anemone

Bracted orchid

Wild blue flax

Wild vetch

Blue-eyed grass

Mountain shooting star

Prairie crocus

Filed mouse-ear chickweed

Common yarrow

Prairie sagewort

Meadow parsnip

Dandelion

Graceful cinquefoil

Bluebur

Veiny meadow rue

Fireweed

Shining arnica
Agropyron dasystachyum

Agropyron trachycaulum

Carex sprengelii

Bromus inermis

Carex sp. 1

Carex sp. 2

Poasp. 1

Poasp. 2

Thermopsis rhombifolia

Fragaria virginiana

Heuchera richardsonii

Vicia americana

Castilleja lutescens

Penstemon procerus

Senecio canus

Gaillardia aristata

Potentilla arguta

Moehringia lateriflora

Solidago canadensis

Anemone multifida

Habeneria viridis

Linum lewisii

Vicia americana

Sisyrinchium montanum

Dodecatheon conjugens

Anemone patens

Cerastium arvense

Achillea millefolium

Artemisia ludoviciana

Zizia aptera

Taraxacum officinale

Potentilla gracilis

Lappula squarrosa

Thalictrum venulosum

Epilobium angustifolium

Arnica fulgens

Star-flowered Solomon's seal Smilacina stellata 



\section{Environmental Characteristics}

Landform:

Soil:

Parent material:

Texture:

Drainage:

Moisture regime:

Soil pH - B horizon:

Slope:

Aspect:

Slope position:

Depth to carbonates: escarpment and coulee slopes; occasionally on level to inclined plains in the southern highlands

Gleyed Dark Brown Chernozem; Orthic Black Chernozem morainal veneer over bedrock

$\mathrm{SiL}$ to gSiL over C

moderately well

mesic to submesic

6.5 to 7.0

$30 \%$ to $35 \%$

north and west facing

upper to lower slopes

$30 \mathrm{~cm}$ 

11. Vegetation/Ecosite Data Sheet:

Silverberry - Rough Fescue - Hooker's Oat Grass

Vegetation type:

Successional status:

Range condition:

Expected climax community:

Nutrient regime:

Mineral soil exposure:
Shrubbery edaphic climax good edaphic climax mesotrophic none

\section{Dominant species}

Mean foliar cover

$\underline{\text { Shrubs }}$

Silverberry

Elaeagnus commutata

Graminoids

Rough Fescue

Festuca scabrella

30

Hooker's oat grass

Helictotrichon hookeri

20

\section{Secondary species}

$\underline{\text { Shrubs }}$

Common wild rose

Rosa woodsii

Graminoids

June grass

Koeleria macrantha

Forbs

Northern bedstraw

Galium boreale

Early yellow locoweed

Oxytropis sreicea

Three-flowered avens

Geum triflorum

Yarrow

Achillea millefolium

Missouri milk vetch

Astragalus missouriensis

Blue-eyed grass

Sisyrinchium montanum

Harebell

Gaillardia

Campanula rotundifolia

Gaillardia aristata 



\section{Environmental Characteristics}

Landform:

Soil:

Parent material:

Texture:

Drainage:

Moisture regime:

Soil pH - B horizon:

Slope:

Aspect:

Slope position:

Depth to carbonates: level plains; coulee and escarpment slopes

variable; Orthic Black Chernozem, Orthic Dark Brown Chernozem, Dark Brown Solod, Dark Brown Solodized Solonetz glaciofluvial and morainal variable; generally coarse textured. moderately well mesic

6.0 to 7.0

variable; usually less than $5 \%$

variable

upper slopes 

12. Vegetation/Ecosite Data Sheet:

\section{Salix/Saskatoon - Rough Fescue/Bluegrass}

Vegetation type:

Successional status:

Range condition:

Expected climax community:

Nutrient regime:

Mineral soil exposure:

\author{
Shrubbery \\ climax \\ good \\ Salix/Saskatoon - Rough Fescue/Bluegrass \\ mesotrophic \\ none
}

\section{Dominant species}

$\underline{\text { Shrubs }}$

Beaked willow

Saskatoon

Graminoids

Rough fescue

Canby bluegrass

Smooth brome

Forbs

Alpine hedysarum

\section{Secondary species}

Shrubs

Buckbrush

Common wild rose

Canada buffaloberry

Silverberry

Choke cherry

Northern gooseberry

Creeping juniper

Red osier dogwood

Graminoids

Northern wheat grass

Sprengel's sedge

Slender wheat grass
Salix bebbiana

Amelanchier alnifolia

30

Festuca scabrella

20

Poa canbyi

Bromus inermis

30

20

Hedysarum alpinum

20
Symphoricarpos occidentale

Rosa woodsii

Shepherdia canadensis

Elaeagnus commutata

Prunus virginiana

Ribes oxyacanthoides

Juniperus horizontalis

Cornus stolonifera

Agropyron dasystachyum

Carex sprengelii

Agropyron trachycaulum 

Forbs

Three-flowered avens

Northern bedstraw

Golden bean

Wild strawberry

Richardson's alumroot

Wild vetch

Stiff yellow paintbrush

Common dandelion

Veiny meadow rue

False dandelion

White camas

White cinquefoul

Western wood lily

Wild strawberry

Meadow parsnip

Golden bean

Field mouse-ear chickweed

Fleabane

Pink wintergreen
Geum triflorum

Galium boreale

Thermopsis rhombifolia

Fragaria virginiana

Heuchera richardsonii

Vicia americana

Castilleja lutescens

Taraxacum officinale

Thalictrum venulosum

Agoseris glauca

Zigadenus elegans

Potentilla arguta

Lilium philadelphicum

Fragaria virginiana

Zizia aptera

Thermopsis rhombifolia

Cerastium arvense

Erigeron glabellus

Pyrola asarifolia

\section{Environmental Characteristics}

Landform:

Soil:

Parent material:

Texture:

Drainage:

Moisture regime:

Soil pH - B horizon:

Slope:

Aspect:

Slope position:

Depth to carbonates: coulee slopes

Orthic Regosol

glaciofluvial; colluvium

$\mathrm{C}$ over $\mathrm{SiCL}$

moderately well to imperfectly

mesic

8.0

$35 \%$ to $55 \%$

north

upper to lower slopes 

13. Vegetation/Ecosite Data Sheet:

\section{Buffaloberry - Rough Fescue}

Vegetation type:

Successional status:

Range condition:

Expected climax community:

Nutrient regime:

Mineral soil exposure:
Shrubbery edaphic climax good edaphic climax mesotrophic $30 \%$ to $35 \%$

\section{Dominant species}

Mean foliar cover

$\underline{\text { Shrubs }}$

Canada buffaloberry

Shepherdia canadensis

Saskatoon Amelanchier alnifolia

Silverberry

Elaeagnus commutata

Buckbrush

Graminoids

Rough fescue

Festuca scabrella

Green needle grass

Stipa viridula

\section{$\underline{\text { Secondary species }}$}

Shrubs

Northern gooseberry

Ribes oxyacanthoides

Beaked willow

Salix bebbiana

Graminoids

Early bluegrass

Poa cusickii

Western porcupine grass

Stipa curtiseta

Wire rush

Sedge

Juncus balticus

Carex sp.

\section{Forbs}

Northern bedstraw

Galium boreale

White cinquefoil Potentilla arguta

Prairie sagewort Artemisia ludoviciana

Wild vetch

Vicia americana 

Collomia

Missouri goldenrod
Collomia linearis

Solidago missouriensis

\section{Environmental Characteristics}

Landform:

Soil:

Parent material:

Texture:

Drainage:

Moisture regime:

Soil pH - B horizon:

Slope:

Aspect:

Slope position:

Depth to carbonates: coulee slopes

Orthic Regosol

colluvium

C over SiCL

moderately well

subxeric

8.0

$35 \%$ to $55 \%$

generally northwest to northeast; also east upper to lower coulee slopes 

14. Vegetation/Ecosite Data Sheet:

\section{Aspen - Buckbrush - Forb - Wheat Grass}

Vegetation type:

Woodlands

Successional status:

climax

Range condition:

fair

Expected climax community:

Aspen-buckbrush-forb-wheat grass

Nutrient regime:

mesotrophic

Mineral soil exposure:

none

\section{Dominant species}

Mean foliar cover

Trees

Aspen

Populus tremuloides

36

$\underline{\text { Shrubs }}$

Buckbrush

Symphoricarpos occidentale

Wild rose

Rosa woodsii

$\underline{\text { Forbs }}$

Common nettle

Urtica dioica

12

Graminoids

Slender wheat grass

Agropyron trachycaulum

\section{Secondary species}

Shrubs

Beaked willow

Choke cherry

Wild raspberry

Northern gooseberry

Poplar

Salix bebbiana

Prunus virginiana

Rubus idaeus

Ribes oxyacanthoides

Populus balsamifera

Graminoids

Awnless brome

Bromus inermis

Foxtail barley

Sprengel's sedge

Hordeum jubatum

Carex sprengelii

Rough fescue

Festuca scabrella 

Bluegrass

Forbs

Wild vetch

Northern bedstraw

Common dandelion

Star-flowered Solomon's seal Smilacina stellata

Cream-coloured vetchling Lathyrus ochroleucus

Field mouse-ear chickweed

Prairie sagewort

Canada thistle

Goat's-beard

Sweet-scented bedstraw

Tufted white prairie aster

Common blue lettuce

Harbell

Pasture sagewort

Blue-eyed Grass

Canada anemone

Blue-bur

Yellow avens

Blunt-leaved sandwort

Meadow parsnip

Common plantain

Veiny meadow rue
Poasp.

Vicia americana

Galium boreale

Taraxacum officinale

Cerastium ludoviciana

Artemisia ludoviciana

Cirsium arvense

Tragopogon dubius

Galium trifolium

Aster ericoides

Lactuca pulchella

Campanula rotundifolia

Artemisia frigida

Sisyrinchium montanum

Anemone canadensis

Lappula squarrosa

Geum aleppicum

Moehringia lateriflora

Zizia aptera

Plantago major

Thalictrum venulosum

\section{Environmental Characteristics}

Landform:

Soil:

Parent material:

Texture:

Drainage:

Moisture regime:

Soil pH - B horizon:

Slope:

Aspect:

Slope position:

Depth to carbonates: coulee slopes; inclined areas on the southern highlands

Orthic Regosol (coulee sites); Orthic Dark Brown Chernozem (highland site)

glaciofluvial (colluvium); morainal

$\mathrm{C}$ over SiCL

moderately well

mesic

8.0

$35 \%$ to $40 \%$ (coulee sites); $4 \%$ to $6 \%$ (highland site) north

upper to lower slopes (coulees); uplands (highland site) 

15. Vegetation/Ecosite Data Sheet:

\section{Aspen - Awnless Brome}

Vegetation type:

Successional status:

Range condition:

Expected climax community:

Nutrient regime:

Mineral soil exposure:
Woodlands

seral

poor

mesotrophic

none

\section{Dominant species}

Trees

Aspen

Populus tremuloides

25

Graminoids

Awnless brome

Bromus inermis

Shrubs

Aspen

Populus tremuloides

\section{Secondary species}

$\underline{\text { Shrubs }}$

Buckbrush

Northern gooseberry

Symphoricarpos occidentale

Ribes oxyacanthoides

Forbs

Northern bedstraw

Galium boreale

Canada thistle

Cirsium arvense

Common dandelion

Taraxacum officinale

Star-flowered

Solomon's seal

Smilacina stellata

Wild vetch

Vicia americana

Veiny meadow rue

Thalictrum venulosum

Bluebur

Lappula squarrosa

Fireweed

Epilobium angustifolium 



\section{Environmental Characteristics}

Landform: level to slightly rolling plain

Soil:

Parent material:

Orthic Black Chernozem

Texture:

glaciofluvial

Drainage:

Moisture regime:

L over CL

Soil pH - B horizon:

moderately well

mesic

Slope:

level to $2 \%$

Aspect:

NA

Slope position: NA

Depth to carbonates: 

16. Vegetation/Ecosite Data Sheet:

\section{Poplar - Buckbrush - Wheat Grass}

Vegetation type:

Successional status:

Range condition:

Expected climax community:

Nutrient regime:

Mineral soil exposure:
Woodlands climax

poor

Poplar - buckbrush - wheat grass mesotrophic

$10 \%$ to $15 \%$

\section{Trees}

Balsam poplar

Populus balsamifera

$\underline{\text { Shrubs }}$

Buckbrush

Symphoricarpos occidentale

Saskatoon

Amelanchier alnifolia

Northern gooseberry

Ribes oxyacanthoides

Common wild rose

Rosa woodsii

Silverberry

Elaeagnus commutata

Canada buffaloberry

Shepherdia canadensis

Beaked willow

Salix bebbiana

Balsam poplar

Populus balsamifera

\section{Forbs}

Canada goldenrod

Wild vetch

Solidago canadensis

Sweet-scented bedstraw

Aster

Vicia americana

Galium trifolium

Aster sp.

Graminoids

Rough fescue

Rough hair grass

Festuca scabrella

Agrostis scabra 



\section{Environmental Characteristics}

Landform:

Soil:

Parent material:

Texture:

Drainage:

Moisture regime:

Soil pH - B horizon:

Slope:

Aspect:

Slope position:

Depth to carbonates: coulee slopes; level plain

Orthic Regosol; Dark Brown Solodized Solonetz

colluvium; morainal

variable

moderately well

mesic

variable; level to low angled slump benches on steep coulee slopes variable

variable 

17. Vegetation/Ecosite Data Sheet:

\section{Mixed Grass - Forb}

Vegetation type:

Successional status:

Range condition:

Expected climax community:

Nutrient regime:

Mineral soil exposure:
Ephemeral Riparian Meadow

climax

variable

edaphic climax

mesotrophic to permesotrophic

none

\section{Dominant species}

Mean foliar cover

Graminoids

Rough fescue

Awnless brome

Festuca scabrella

18

Bromus inermis

$\underline{\text { Shrubs }}$

Buckbrush

Symphoricarpos occidentale

Secondary species

Graminoids

Green needle grass

Stipa viridula

Hooker's oat grass

Helictotrichon hookeri

Interior bluegrass

Poa interior

Western porcupine grass

Stipa curtiseta

Western wheat grass

Low sedge

Agropyron dasystachyum

Blunt sedge

Carex stenophylla

Sprengel's sedge

Carex obtusata

June grass

Carex sprengelii

Koeleria macrantha

Wire rush

Juncus balticus

Oat grass

Danthonia californica

Tufted hair grass

Deschampsia cespitosa

Western wheat grass

Agropyron smithii 

Shrubs

Common wild rose

Rosa woodsii

Creeping juniper

Juniperus horizontalis

Northern gooseberry

Ribes oxyacanthoides

Forbs

Wild vetch

Fireweed

Northern bedstraw

Prairie sagewort

Stiff yellow paintbrush

Veiny meadowrue

Shining arnica

Harebell

Blunt-leaved sandwort

False dandelion

White cinquefoil

Prairie sagewort

Slender blue beard tongue

Blue-eyed grass

White camas

Northern Buttercup

Dandelion

Common yarrow

Golden bean

Richardson's alumroot

Cream-colored vetchling

Alpine hedysarum

Early yellow locoweed

Cut-leaved anemone

Western wood lily

Gaillardia

Three-flowered avens

Fireweed

Canada goldenrod

Meadow parsnip

Vicia americana

Epilobium angustifolium

Galium boreale

Artemisia ludoviciana

Castilleja lutescens

Thalictrum venulosum

Arnica fulgens

Campanula rotundifolia

Moeringhia lateriflora

Agoseris glauca

Potentilla arguta

Artemisia ludoviciana

Penstemon procerus

Sisyrinchium montanum

Zigadenus elegans

Ranunculus pedatifidus

Taraxacum officinale

Achillea millefolium

Thermopsis rhombifolia

Heuchera richardsonii

Lathyrus ochroleucus

Hedysarum alpinum

Oxytropis sericea

Anemone multifida

Lilium philadelphicum

Gaillardia aristata

Geum triflorum

Epilobium angustifolium

Solidago canadensis

Zizia aptera 



\section{Environmental Characteristics}

Landform:

Soil:

Parent material:

Texture:

Drainage:

Moisture regime:

Soil pH - B horizon:

Slope:

Aspect:

Slope position:

Depth to carbonates: slight depressions and drainage channels on level plains and low angled slopes

mainly Orthic Black and Orthic Brown Chernozems; occasionally on Dark Brown Solodized Solonetz. glaciofluvial and morainal $\mathrm{CL}$ to $\mathrm{L}$ over $\mathrm{SiCL}$ to $\mathrm{CL}$ moderately well to imperfect mesic to subhygric

6.0 to 7.0

$1 \%$ to $2 \%$

NA

NA 

18. Vegetation/Ecosite Data Sheet:

\section{Rough Hair Grass - Sedge - Forb}

Vegetation type:

Ephemeral Riparian Meadow

Successional status:

seral

Range condition:

fair

Expected climax community:

Nutrient regime:

permesotrophic

Mineral soil exposure:

none

Dominant species

Mean foliar cover

Graminoids

Rough hair grass

Awned sedge

Agrostis scabra

30

Carex atherodes 20

$\underline{\text { Shrubs }}$

Buckbrush

Symphoricarpos occidentalis

10

\section{Secondary species}

Graminoids

Fowl bluegrass

Poa palustris

Foxtail barley

Wire rush

Green needle grass

Hordeum jubatum

Juncus balticus

Slender wheat grass

Stipa viridula

Agropyron trachycaulum

Early bluegrass

Poa cusickii

Northern reed grass

Sedge

Calamagrostis inexpansa

Carex sp.

Awned sedge

Carex atherodes

$\underline{\text { Shrubs }}$

Common wild rose

Rosa woodsii

Canada buffaloberry

Shepherdia canadensis

Silverberry

Elaeagnus commutata

Beaked willow

Salix bebbiana 

Forbs

Wild mint

Canada thistle

Smooth scouring-rush

Common dandelion

White cinquefoil

Blunt-leaved sandwort

Canada anemone

Wild vetch

Prairie sagewort

Meadow parsnip

Water parsnip

Common yarrow

Narrow-leaved dock

Field horsetail

Narrow-leaved hawkweed
Mentha arvensis

Cirsium arvense

Equisetum laevigatum

Taraxacum officinale

Potentilla arguta

Moehringia lateriflora

Anemone canadensis

Vicia americana

Artemisia ludoviciana

Zizia aptera

Sium suave

Achillea millefolium

Rumex triangulivalis

Equisetum arvense

Hieracium umbellatum

\section{Environmental Characteristics}

Landform: coulee bottom

Soil:

Parent material:

Gleyed Regosol

Texture:

Drainage:

fluvial

Moisture regime:

CL over C

poorly

hygric

Soil pH - B horizon:

8.0

Slope:

$0 \%$

Aspect:

NA

Slope position:

coulee bottom

Depth to carbonates: 

19. Vegetation/Ecosite Data Sheet:

\section{Bluegrass - Rough Hair Grass - Cinquefoil}

Vegetation type:

Successional status:

Range condition:

Expected climax community:

Nutrient regime:

Mineral soil exposure:
Wetlands

seral

fair

mesotrophic

none

\section{Dominant species}

Mean foliar cover

Graminoids

Fowl Bluegrass

Rough Hair Grass

Nuttall's salt-meadow

grass

Poa palustris

32

Agrostis scabra

21

Puccinellia nuttalliana

9

$\underline{\text { Forbs }}$

Silverweed

Potentilla anserina

\section{Secondary species}

Graminoids

Woolly sedge

Meadow sedge

Carex lanuginosa

Foxtail barley

Carex praticola

Hordeum jubatum

Salt grass

Distichlis stricta

Northern reed grass

Calamagrostis inexpansa

Forbs

Common dandelion

Taraxacum officinale

Prairie sagewort

Artemesia ludoviciana

Gumweed

Common yarrow

Perennial sow-thistle

Grindelia Squarrosa

Achillea millefolium

Sonchus arvensis

Cinquefoil

Potentilla norvegica 



\section{Environmental Characteristics}

Landform: $\quad$ slight depressional areas in the level plain

Soil:

Parent material:

Orthic Dark Brown Chernozem

Texture:

Drainage:

lacustrine

Moisture regime:

clay

poor

Soil pH - B horizon:

mesic

Slope:

8.0

none

Aspect:

none

Depth to carbonates: 

20. Vegetation/Ecosite Data Sheet:

\section{Sedge - Rough Hair Grass community}

Vegetation type:

Successional status:

Range condition:

Expected climax community:

Nutrient regime:

Mineral soil exposure:
Wetlands

edaphic climax

good

edaphic climax

mesotrophic to permesotrophic

none

\section{Dominant species}

Mean foliar cover

Gramonoids

Woolly sedge

Awned sedge

Rough hair grass

Fowl bluegrass

Carex lanuginosa

42

Carex atherodes

10

Agrostis scabra

25

Poa palustris

\section{Secondary species}

Graminoids

Wire rush

Foxtail barley

Juncus balticus

Hordeum jubatum

Blunt sedge

Carex obtusata

Western wheat grass

Agropyron smithii

Slough grass

Beckmania syzigachne

Meadow foxtail

Alopecurus pratensis

Slender wheat grass

Agropyron trachycaulum

Water sedge

Carex aquatilis

Interior bluegrass

Sweet grass

Poa interior

Hierachloe odorata

Forbs

Wild mint

Prairie sagewort

Mentha arvensis

Gumweed

Artemisia ludoviciana

Shining arnica

Wild mint

Grindelia squarrosa

Arnica fulgens

Mentha arvensis

Western dock

Rumex occidentalis 

Dandelion

$\underline{\text { Shrubs }}$

Buckbrush

Environmental Characteristics

Landform:

Soil:

Parent material:

Texture:

Drainage:

Moisture regime:

Soil $\mathrm{pH}$ - B horizon:

Slope:

Aspect:

Slope position:

Depth to carbonates:
Taraxacum officinale

Symphoricarpos occidentalis slight depressions in level plains

Humic Luvic Gleysol

morainal veneers

$\mathrm{SiCL}$ and $\mathrm{SiC}$

imperfectly to poorly

hygric

5.5 to 8.0

none

NA

NA 

21. Vegetation/Ecosite Data Sheet:

\section{Sedge - Wire Rush community}

Vegetation type:

Successional status:

Range condition:

Expected climax community:

Nutrient regime:

Mineral soil exposure:
Wetlands

edaphic climax

fair

edaphic climax

permesotrophic

none

\section{Dominant species}

Mean foliar cover

Graminoids

Douglas sedge

Wire rush

Carex douglasii

Juncus balticus
40

30

Secondary species

Forbs

Seaside buttercup

Smooth scouring-rush

Ranunculus cymbalaria

Equisetum laevigatum

\section{Environmental Characteristics}

Landform:

Soil:

Parent material:

Texture:

Drainage:

Moisture regime

Soil pH - B horizon:

Slope:

Aspect:

Slope position:

Depth to carbonates: depressional drainage areas; bottom of coulees Orthic Luvic Gleysol

fluvial

LSi over gC very poorly

subhydric

8.0

none

NA

depressional 



\section{Appendix II. Annotated list of plant species}

The information presented here is based on field surveys done for this study and is an update of related information given in Wallis and Wershler (1985).

\section{SELAGINACEAE}

Selaginella densa. Common in grassland.

\section{EQUISETACEAE}

Equisetum laevigatum. Occasional in moist soils.

OPHIOGLOSSACEAE

Botrychium lunaria. Rare in fescue grassland. Disjunct population; separate from its normal western and north-central distribution.

\section{CUPRESSACEAE}

Juniper horizontalis. Fairly common on coulee slopes.

\section{GRAMINEAE}

Agropyron dasystachyum. Occasional in grasslands.

Agropyron pectiniforme. Introduced; planted on reclaimed well sites.

Agropyron smithii. Occasional in grasslands; most common on solonetzic soils near drainage from Little Fish Lake.

Agropyron trachycaulum var. trachycaulum. Occasional, especially on heavier, clay soils.

Agropyron trachycaulum var. unilaterale. Fairly common in fescue grassland.

Agrostis scabra. Locally common around the edges of damp depressions.

Beckmania syzigachne. Occasional in moist depressions.

Bouteloua gracilis. Locally fairly common; occurs only in heavily grazed sites, and on dry, exposed and less developed soils in the southwest corner of the study area.

Bromus inermis. Locally abundant in the northeast corner of the study area, in aspen copses and drainage channels.

Calamagrostis inexpansa. Occasional in moist soils.

Calamovilfa longifolia. Locally fairly common on dry sandy coulee slopes.

Danthonia californica. Widespread and fairly common in fescue grasslands.

Distichlis stricta. Occasional on solonetzic soils near Little Fish Lake drainage channel.

Festuca scabrella. Dominant species of fescue grassland areas which are not heavily grazed.

Hierachloe odorata. Uncommon in moist soils.

Helictotrichon hookeri. Common in fescue grasslands.

Hordeum jubatum. Common in damp depressions.

Koeleria macrantha. Dominant in heavily grazed grasslands; fairly common in other grassland areas.

Muhlenbergia cuspidata. Occasional on coulee slopes. 

Poa canbyi. Occasional in coulees.

Poa cusickii. Fairly common in coulees.

Poa interior. Locally abundant in fescue grasslands.

Poa palustris. Locally common in damp depressions.

Puccinellia nuttalliana. Occasional in damp depressions.

Spartina gracilis. Occasional in alkaline seepage areas.

Stipa comata. Occasional in drier exposed soils of the southwest corner of the study area.

Stipa curtiseta. Co-dominant in fescue grassland.

Stipa viridula. Locally fairly common on moist coulee slopes, especially north-facing slopes.

\section{CYPERACEAE}

Carex atherodes. Dominant in damp depressions; also occurs along wet coulee drainages.

Carex douglassii. Uncommon in coulees.

Carex lanuginosa. Locally common along creek channels.

Carex obtusata. Widespread and fairly common in grasslands, especially more heavily grazed areas.

Carex praticola. Locally fairly common in damp depressions.

Carex sprengelii. Locally common along coulee drainages.

Carex stenophylla. Fairly common in grazed grasslands; increases with level of grazing.

\section{JUNCACEAE}

Juncus balticus. Occasional in moister soils in fescue grasslands.

Juncus confusus. Reported by Wallis and Wershler (1985) as occurring in moist depressions in the fescue grasslands in the northeast part of the study area. Found only in six other locations in Alberta (Moss 1983).

\section{LILIACEAE}

Allium textile. Occasional along grassy coulee slopes.

Disporum trachycarpum. Occasional in coulee woods .

Lilium philadelphicum. Occasional in ungrazed fescue grasslands, and on moist coulee slopes.

Smilacina stellata. Fairly common in shrub thickets and woodlands in coulees.

Zigadenus elegans. Uncommon; found in fescue grassland and on moist coulee slopes.

Zigadenus venenosus. Fairly common in fescue grassland.

\section{IRIDACEAE}

Sisyrinchium montanum. Occasional in fescue grassland.

\section{ORCHIDACEAE}

Habenaria viridis. Found on a moist coulee slope.

\section{SALICACEAE}

Populus tremuloides. Aspen copses are found primarily in the northeast part of the study area; aspen woodlands also occur on north-facing slopes of coulees.

Salix bebbiana. Dominant in willow stands occuring in moist areas of coulees. 

Salix exigua. Uncommon; found on low beach ridge near Little Fish Lake basin.

URTICACEAE

Urtica dioica. Occasional in upland aspen copses and in coulee thickets.

SANTALACEAE

Comandra umbellata. Occasional along open coulee slopes.

POLYGONACEAE

Eriogonum flavum. Occasional on dry exposed coulee slopes.

Polygonum douglasii. Occasional on solonetzic soils near Little Fish Lake.

Rumex occidentalis. Occasional in damp depressions.

Rumex triangulivalvis. Occasional in damp depressions.

\section{CHENOPODIACEAE}

Monolepis nuttalliana. Occasional in solonetzic soils adjacent to drainage from Little Fish Lake.

Suaeda calceoliformis. Occasional in solonetzic soils adjacent to drainage from Little Fish Lake.

\section{CARYOPHYLLACEAE}

Cerastium arvense. Common in fescue grasslands.

Moehringia lateriflora. Occasional in shrubby areas and coulee woodlands.

Paronychia sessiliflora. Uncommon on dry exposed coulee slopes.

Silene drummondii. Uncommon in fescue grasslands.

Stellaria longipes. Occasional on moist soils such as along intermittent drainage channels.

\section{RANUNCULACEAE}

Actaea rubra. Occasional in shrub thickets.

Anemone canadensis. Fairly common in coulee woodlands.

Anemone cylindrica. Occasional in fescue grassland .

Anemone multifida. Occasional in drier fescue grasslands .

Anemone patens. Common in fescue grasslands.

Ranunculus cardiophyllus. Occasional in moist areas in fescue grasslands.

Ranunculus cymbalaria. Fairly common in damp areas along Little Fish Lake drainage channel.

Ranunculus pedatifidus. Reported by Wallis and Wershler (1985). Edge of distribution.

Thalictrum venulosum. Occasional in coulee woodlands and moist areas of fescue grasslands.

\section{CRUCIFERAE}

Arabis divaricarpa. Occasional in grasslands.

Arabis hirsuta. Occasional in moist grasslands.

Arabis holboellii var. retrofracta. Occasional in coulee grasslands.

Draba nemorosa. Occasional on sandy soils in grassland.

Erysimum cheiranthoides. Uncommon. A weed of disturbed areas and roadsides. Found in grazed fescue grassland area adjacent to Little Fish Lake. 

Erysimum inconspicuum. Occasional in grasslands.

\section{SAXIFRAGACEAE}

Heuchera richardsonii. Scattered and uncommon in fescue grasslands.

\section{GROSSULARIACEAE}

Ribes oxyacanthoides. Occasional in coulee woodlands; also found along beach ridge of Little Fish Lake basin.

\section{ROSACEAE}

Amelanchier alnifolia. Fairly common in coulee shrubbery, and in moist parts of coulee grasslands. Fragaria virginiana. Locally abundant in coulee shrubbery and woodlands.

Geum aleppicum. Scarce in the study area; found in moist soils near coulee drainages. Edge of its distribution.

Geum triflorum. Common and locally abundant in fescue grasslands; increases with minor amounts of grazing.

Potentilla anserina. Common in clay and solonetzic soils adjacent to drainage from Little Fish Lake and in damp depressions.

Potentilla arguta. Fairly common along moist ephemeral drainage channels in fescue grassland in the northeast part of the study area.

Potentilla bipinnatifida. Occasional in moist areas in fescue grassland in the northeastern part of the study area.

Potentilla concinna. Occasional in fescue grassland.

Potentilla gracilis. Fairly common in fescue grassland.

Potentilla hippiana. Uncommon in fescue grassland

Potentilla norvegica. Occasional on disturbed wet ground; found in wet soils adjacent to drainage from Little Fish Lake.

Potentilla pensylvanica. Occasional in grasslands.

Prunus virginiana. Common in coulee woodlands and shrublands.

Rosa arkansana. Fairly common along coulee slopes; occasional in upland grasslands

Rosa woodsii. Common in coulee woodlands and shrublands.

Rubus idaeus. Uncommon in coulee woodlands and shrublands.

\section{LEGUMINOSAE}

Astragalus bisulcatus. Occasional in fescue and coulee grasslands .

Astragalus crassicarpus. Uncommon on coulee slopes and upland grasslands.

Astragalus dasyglottis. Fairly common in fescue grasslands.

Astragalus drummondii. Occasional in drier grasslands .

Astragalus flexuosus. Occasional in grasslands .

Astragalus missouriensis. Occasional in drier grasslands .

Astragalus pectinatus. Uncommon; found on dry grasslands with clayey soils.

Astragalus striatus. Occasional in dry grasslands.

Astragalus tenellus. Occasional in coulee and mixed grasslands. 

Glycyrrhiza lepidota. Occasional in coulee bottoms.

Hedysarum alpinum. Fairly common in moist areas of fescue grasslands, especially near ephemeral drainage channels in the northeast part of the study area, and on north-facing coulee slopes.

Lathyrus ochroleucus. Fairly common in coulee woodlands and shrublands.

Lupinus argenteus. Uncommon on south-facing coulee slopes.

Oxytropis monticola. Occasional in grasslands.

Oxytropis sericea. Occasional in moist grassland areas.

Psoralea esculenta. Scarce on dry coulee slopes.

Thermopsis rhombifolia. Common in grasslands.

Vicia americana. Fairly common in fescue grassland and coulee shrubbery .

LINACEAE

Linum lewisii. Occasional in fescue grasslands.

MALVACEAE

Sphaeralcea coccinea. Occasional on coulee slopes.

\section{VIOLACEAE}

Viola adunca. Occasional on moist coulee slopes.

Viola canadensis. Scarce in coulee woodlands and shrublands.

Viola nuttallii. Uncommon on dry coulee slopes.

Viola pedatifida. Uncommon in ungrazed fescue grassland. Recorded by Wallis and Wershler (1985). One of only five recorded collections in Alberta (Packer and Bradley 1984).

CACTACEAE

Opuntia polyacantha. Occasional on south-facing coulee slopes .

\section{ELAEAGNACEAE}

Elaeagnus commutata. Dominant shrub species on coarse-textured soils, such as in drainage channels in the northwest part of the study area, along a beach ridge near Little Fish Lake, and on coulee slopes.

Shepherdia canadensis. Occasional on coulee slopes .

\section{ONAGRACEAE}

Epilobium angustifolium. Locally abundant in aspen copses and drainage channels in the northeast corner.

Gaura coccinea. Occasional on coulee slopes and in drier grasslands.

Oenothera breviflora. Reported by Wallis and Wershler 1985 as rare along the shore of Little Fish Lake; may occur in the Ecological Reserve. Rare in Alberta; found only in three localities in the province.

\section{UMBELLIFERAE}

Cymopterus acaulis. Uncommon on coulee slopes. 

Lomatium foeniculaceum. Occasional in dry grasslands

Lomatium macrocarpum. Uncommon on coulee slopes

Musineon divericatum. Occasional in drier grasslands .

Sium suave. Uncommon in moist sites along coulee drainages.

Zizia aptera. Fairly common in moister areas of fescue grasslands .

\section{CORNACEAE}

Cornus stolonifera. Fairly common in coulee woodlands and shrublands .

\section{PYROLACEAE}

Pyrola asarifolia. Occasional in coulee shrubbery and woodlands.

\section{PRIMULACEAE}

Androsace septentrionalis. Widespread in grasslands .

Dodecatheon conjugens. Occasional in fescue grasslands .

Glaux maritima. Occasional on solonetzic soils west of Little Fish Lake .

Primula incana. Uncommon on moist coulee bottoms .

\section{GENTIANACEAE}

Gentianella amarella. Occasional on moist coulee slopes.

\section{POLEMONIACEAE}

Collomia linearis. Uncommon on dry coulee slopes.

Phlox hoodii. Found on dry coulee slopes and occasionally in drier grassland areas.

\section{BORAGINACEAE}

Hackelia americana. Occasional in shrub thickets in coulees.

Lappula squarrosa. Occassional in coulee woodlands.

\section{LABIATAE}

Mentha arvensis. Uncommon on wet soils.

SCROPHULARIACEAE

Castilleja lutescens. Common and locally abundant in fescue grassland. Cordilleran species.

Penstemon procerus. Occasional in fescue grasslands and moist coulee slopes.

\section{OROBANCHACEAE}

Orobanche fasciculata. Rare in moderately grazed grassland in the southeast corner .

PLANTAGINACEAE

Plantago eriopoda. Occasional on solonetzic soils associated with drainage channel from Little Fish Lake. 


\section{.}




\section{RUBIACEAE}

Galium boreale. Common in moister areas of fescue grasslands.

\section{CAPRIFOLIACEAE}

Lonicera dioica. Occasional in coulee woodlands.

Symphoricarpos albus. Occasional in coulee woodlands.

Symphoricarpos occidentalis. Dominant shrub of upland shrub thickets; common in moister areas of fescue grasslands, such as old drainage channels.

\section{CAMPANULACEAE}

Campanula rotundifolia. Common and widespread in grasslands .

\section{COMPOSITAE}

Achillea millefolium. Occasional in grasslands .

Agoseris glauca. Occasional in fescue grasslands.

Antennaria aprica. Locally abundant in heavily grazed grasslands and on dry soils.

Arnica fulgens. Occasional in fescue grasslands .

Artemisia frigida. Widespread in grasslands; most common on heavier grazed areas.

Artemisia ludoviciana. Common in fescue grasslands .

Aster ciliolatus. Rare in coulee woodlands; reported by Wallis and Wershler (1985).

Aster ericoides. Occasional in grasslands, especially in more heavily grazed areas.

Aster falcatus. Occasional in grasslands .

Aster hesperius. Occasional along moist stream channels in coulees .

Aster laevis. Fairly common in moist fescue grassland, and in coulee woodlands.

Cirsium arvense. Occasional in disturbed areas, and near dugouts.

Cirsium flodmanii. Reported by Wallis and Wershler (1985) as occasional in coulee grasslands.

Cirsium undulatum. Rare in drier grasslands .

Erigeron caespitosus. Fairly common in dry grasslands.

Erigeron glabellus. Fairly common in fescue grasslands and shrub thickets .

Gaillardia aristata. Occasional in upland grasslands and grassy coulee slopes.

Grindelia squarrosa. Fairly common on solonetzic soils near drainage channel of Little Fish Lake. Haplopappus spinulosus. Occasional in drier grasslands .

Helianthus subrhomboideus. Occurs in moist ephemeral drainage channels in ungrazed fescue grassland in the northeast part of the study area .

Heterotheca villosa. Common in dry grasslands.

Hieracium umbellatum. Occasional in coulee shrubbery .

Hymenoxys richardsonii. Occasional on coulee slopes .

Iva axillaris. Locally common on solonetzic soils near the drainage channel from Little Fish Lake. Senecio canus. Occasional on coulee slopes and in grasslands .

Solidago canadensis. Fairly common in moister areas of fescue grasslands and on north-facing coulee slopes.

Solidago missouriensis. Fairly common in fescue grassland.

Sonchus arvensis. Common along a road in the northeast part of the study area. Introduced weedy 

species.

Taraxacum officinale. Occasional throughout study area; common in heavily grazed areas. Tragopogon dubius. Occasional in grasslands. 



\section{Appendix III Annotated List of the Fish}

The following information on fish species within the Reserve was taken from Nelson and Paetz (1992). These three species are the only ones which, according to currently known distribution and habitat requirements, may be found within the Reserve.

\section{Cyprinidae (Minnow)}

Lake Chub (Couesius plumbeus): marsh and small ponds near Little Fish Lake; can be abundant.

Fathead Minnow (Pimephales promelas): marsh and small ponds near Little Fish Lake; tolerant of extremes in salinity and $\mathrm{pH}$.

Gasterosteidae (Stickleback)

Brook Stickleback (Culaea inconstans): marsh and small ponds adjacent to shoreline of LFL. Often the most abundant fish in small waterbodies and usually associated with the Fathead Minnow. 



\section{Appendix IV Annotated List of the Herpetofauna}

The following information on the amphibians and reptiles of the Reserve was taken from Russell and Bauer (1993), Wallis and Wershler (1985) and supplemented by field notes. Common names of families are taken from Cook (1984).

Ambystomatidae (Mole Salamanders)

Tiger Salamander (Ambystoma tigrinum): found near ponds and dugouts in grassland areas. Tolerant of very dry conditions.

Pelobatidae (Spadefoot Toads)

Plains Spadefoot Toad (Scaphiopus bombifrons): may be found around the marsh and small ponds near the shoreline of LFL, where sandy soils occurs.

Bufonidae (Toads)

Canadian Toad (Bufo hemiophrys): vicinity of the marsh and small ponds along the shoreline of LFL. This species may overwinter in communal sites.

\section{Hylidae (Tree Frogs)}

Striped Chorus Frog (Pseudacris triseriata): marsh and small ponds along the shoreline of Little Fish Lake and in the coulee wetlands. One was heard calling in a marsh.

Ranidae (True Frogs)

Leopard Frog (Rana pipiens): marshes and small ponds, preferably with a dense cover of aquatic vegetation. Hibernates in the mud at bottom of bodies of standing water. Preyed upon by the Wandering and the Red-sided Garter Snakes. One was recorded in 1970 in the northeast part of Reserve.

Wood Frog (Rana sylvatica): areas associated with open ponds, but will forage far from water.

Colubridae (Typical Snakes)

Western Hog-nosed Snake (Heterodon nasicus): sandy or gravelly areas with a low vegetation cover; also dry stream bottoms, such as in the bottom of coulees. Prefers these habitat types in the vicinity of water. The Reserve is at the northern limit of its range in North America.

Bull Snake (Pituophis melanoleucus): dry grassland areas, usually associated with sandy soils and rock piles. This habitat is found along the shoreline of Little Fish Lake. The Reserve is at the northern limit of its range in North America.

Wandering Garter Snake (Thamnophis elegans): often found near water but can also be found in dry grasslands. This species spends the winter in communal dens, either natural crevices or abandoned mammal burrows. 

Plains garter Snake (Thamnophis radix): ponds, marshes and dugouts. Winters in hibernacula, i.e. small mammal burrows or rock piles.

Red-sided Garter Snake (Thamnophis sirtalis): vicinity of ponds, marshes and dugouts. Winters in hibernacula. Has been recorded in fescue grassland between aspen clones.

\section{Viperidae (Vipers)}

Prairie Rattlesnake (Crotalus viridis): drier area of grasslands, usually in conjunction with sandy soils or rock piles. May den communally in mammal burrows, i.e. hibernacula. 



\section{Appendix V Annotated List of Birds}

The following information on the birds of the Reserve was taken principally from Semenchuk (1992), Cottonwood (1985) and augmented by field notes.

H: habitat usually favoured

$\mathrm{N}$ : nesting habitat and/or location

Podicipedidae (Grebes)

Horned Grebe (Podiceps auritus)

$\mathrm{H}$ : sloughs and ponds with extensive aquatic vegetation.

$\mathrm{N}$ : floating nest of aquatic plants anchored to reeds in shallow water.

Eared Grebe (Podiceps nigricollis)

$\mathrm{H}$ : sloughs, ponds and shallow lakes with extensive aquatic vegetation.

$\mathrm{N}$ : clonial nester, on large lakes.

Ardeidae (Herons and Bitterns)

American Bittern (Botarus lentiginosus)

$\mathrm{H}$ : secluded shallow marshes .

$\mathrm{N}$ : no suitable breeding habitat within the Reserve.

Great Blue Heron (Ardea herodias)

$\mathrm{H}$ : shallow open water of ponds, sloughs and lakes.

$\mathrm{N}$ : no suitable breeding habitat within the Reserve.

Recorded several times foraging in the marsh.

Black-crowned Night Heron (Nycticorax nycticorax)

$\mathrm{H}$ : large water bosies with dense emergent vegetation.

$\mathrm{N}$ : no suitable breeding habitat within the Reserve.

Anatidae (Ducks and Geese)

Snow Goose (Chen caerulescens)

$\mathrm{H}$ : shallow waters of large lakes.

Several hundred have been recorded along the shore of Little Fish lake during fall migration.

Canada Goose (Branta canadensis)

$\mathrm{H}$ : all shallow wetland types with open water.

$\mathrm{N}$ : variable; nests are located close to water.

Occasionally seen along the shore of Little Fish lake. 

Green-winged Teal (Anas crecca)

$\mathrm{H}$ : shallow sloughs and ponds.

$\mathrm{N}$ : on dry ground near sloughs.

Summer resident

\section{Mallard (Anas platyrhynchos)}

$\mathrm{H}$ : variable; found in all waterbody types.

$\mathrm{N}$ : on dry ground with tall vegetative cover; usually near water.

Common in the Reserve.

Northern Pintail (Anas acuta)

$\mathrm{H}$ : shallow ponds and sloughs in open terrain.

$\mathrm{N}$ : dry ground in sparse vegetation.

Nests have been found in the Reserve. Common summer resident.

Blue-winged Teal (Anas discors)

$\mathrm{H}$ : marshes, sloughs, and dugouts.

$\mathrm{N}$ : dry ground near water.

Nests have been found in the Reserve. Several pairs were seen in the marsh.

Cinnamon Teal (Anas cyanaptera)

$\mathrm{H}$ : marshes, dugouts and shallow margins of lakes.

$\mathrm{N}$ : widely variable; from water's edge to some distance from water.

Occasional summer visitor.

Northern Shoveler (Anas clypeata)

$\mathrm{H}$ : marshes and ponds with abundant vegetative cover.

$\mathrm{N}$ : dry ground with some vegetation, usually near water.

Common summer resident. One pair found in the marsh; other birds found in beaver ponds.

Gadwall (Anas strepera)

$\mathrm{H}$ : marshes, sloughs and shallow lake margins.

$\mathrm{N}$ : dry ground near water, nest well concealed by vegetation.

Common summer resident. Breeds in the marsh.

American Wigeon (Anas americana)

$\mathrm{H}$ : marshes and ponds with fairly dense emergent vegetation.

$\mathrm{N}$ : dry ground where the nest can be hidden in tall grass or shrubbery.

Occasionally found in the Reserve. 

Canvasback (Aythya valisineria)

$\mathrm{H}$ : open ponds and lakes with vegetated margins.

$\mathrm{N}$ : within, or along the border of, wetlands.

Uncommon. Female with brood found in the marsh.

Redhead (Aythya americana)

$\mathrm{H}$ : waterbodies with dense emergent vegetation.

$\mathrm{N}$ : dry ground or on the water, always in high, dense emergent vegetation.

Occasional summer visitor.

Lesser Scaup (Aythya affinis)

$\mathrm{H}$ : lakes with dense reeds or cattail borders.

$\mathrm{N}$ : dry ground in tall grass or sedge meadows, near water.

One pair seen in the marsh.

White-winged Scoter (Melanitta fusca)

$\mathrm{H}$ : ponds and lakes.

$\mathrm{N}$ : in low, dense ground cover.

Occasionally recorded in Little Fish lake.

Common Goldeneye (Bucephala clangula

$\mathrm{H}$ : lakes and large ponds.

$\mathrm{N}$ : no suitable nesting habitat within the Reserve.

Recorded twice at Little Fish lake.

Bufflehead (Bucephalus albeola)

$\mathrm{H}$ : small lakes with vegetated margins.

$\mathrm{N}$ : no suitable nesting habitat within the Reserve.

Occasionally recorded in the Reserve.

Common Merganser (Mergus merganser)

$\mathrm{H}$ : lakes or open ponds.

$\mathrm{N}$ : no suitable nesting habitat within the Reserve.

One individual seen in the marsh.

Accipitridae (Hawks, Eagles and Allies)

Bald Eagle (Haliaeetus leucocephalus)

$\mathrm{H}$ : large open water bodies.

$\mathrm{N}$ : no suitable nesting habitat within the Reserve.

Migrant recorded occasionally. 



\section{Northern Harrier (Circus cyaneus)}

$\mathrm{H}$ : open landscapes, including meadows, marshes and grasslands.

$\mathrm{N}$ : ground nester, usually in patches of low shrubbery.

Commonly seen foraging in the reserve.

Sharp-shinned Hawk (Accipiter striatus)

$\mathrm{H}$ : deciduous woodlands; would be found in the coulees and around the aspen copses.

Probably only seen as a migrant.

Cooper's Hawk (Accipiter cooperii)

$\mathrm{H}$ : deciduous woodlands; would be found in the coulees and around the aspen copses.

$\mathrm{N}$ : in dense tree stands.

Probably seen only as a migrant.

Swainson's Hawk (Buteo swainsoni)

$\mathrm{H}$ : open grasslands with scattered woodlands.

$\mathrm{N}$ : usually deciduous trees, occasionally tall shrubs.

Common summer resident.

Red-tailed Hawk (Buteo jamaicensis)

$\mathrm{H}$ : open grasslands with scattered woodlands.

$\mathrm{N}$ : usually tall trees.

Summer resident.

Ferruginous Hawk (Buteo regalis)

$\mathrm{H}$ : open grasslands.

$\mathrm{N}$ : trees, sometimes coulee ledges.

Summer resident. Seen foraging in the Reserve several times.

Golden Eagle (Aquila chrysaetos)

$\mathrm{H}$ : grasslands with coulees.

$\mathrm{N}$ : no suitable nesting habitat within the Reserve.

Falconidae (Falcons)

American Kestrel (Falco sparverius)

$\mathrm{H}$ : open landscapes with a scattered woodlands.

$\mathrm{N}$ : cavity nester in deciduous trees, or in abandoned stick nests.

Summer resident. 

Merlin (Falco columbarius)

$\mathrm{H}$ : open landscapes with a scattered woodlands.

$\mathrm{N}$ : abandoned crow or magpie stick nests; occasional cavity nester.

Recorded several times in the Reserve, usually around the aspen clones in section 25 but also in other areas. At least three active nests found in 1974.

Peregrine Falcon (Falco peregrinus)

$\mathrm{H}$ : open grasslands, and marsh areas.

Has been recorded overflying the area.

Prairie Falcon (Falco mexicanus)

$\mathrm{H}$ : open grasslands, especially in the vicinity of coulees.

$\mathrm{N}$ : no suitable nesting habitat within the Reserve.

Occasional summer resident. Probably nests in nearby Willow Creek badlands.

Phasianidae (Pheasants and Allies)

Gray Partridge (Perdix perdix)

$\mathrm{H}$ : open grassland with nearby shrub cover.

$\mathrm{N}$ : ground nester; in tall grass or low shrubbery.

Sharp-tailed Grouse (Tympanuchus phasianellus)

$\mathrm{H}$ : open grasslands and coulee habitats.

$\mathrm{N}$ : ground nester; in tall grass, low shrubbery or woodlands.

Adults and young juveniles recorded in the central part of the Reserve. Adults found in the danse fescue of section 25 .

\section{Rallidae (Rails)}

American Coot (Fulica americana)

$\mathrm{H}$ : ponds, lakes and sloughs with open water and margins of emergent vegetation.

$\mathrm{N}$ : in dense rushes or cattails adjacent to water.

Common on the marsh; adults and juveniles.

\section{Charadriidae (Plovers)}

Black-bellied Plover (Pluvialis squatarola)

$\mathrm{H}$ : migrant;

Lesser Golden-Plover (Pluvialis dominica)

$\mathrm{H}$ : migrant; 

Semipalmated plover (Charadrius semipalmatus)

$\mathrm{H}$ : migrant; open margins of waterbodies.

Piping Plover (Charadrius melodus)

$\mathrm{H}$ : gravelly or sandy beaches with open shorelines.

$\mathrm{N}$ : unvegetated or sparsely vegetated gravelly beaches; ground nester.

Nests along the shore of Little Fish lake.

Killdeer (Charadrius vociferus)

$\mathrm{H}$ : open grasslands, shores of lakes and ponds.

$\mathrm{N}$ : ground nester; usually open gravelly areas.

Common around the wetlands, especially the marsh.

Recurvirostridae (Stilts and Avocets)

Amercan Avocet (Recurvirostra americana)

$\mathrm{H}$ : shallow alkaline or saline waterbodies; marshes and wet meadows.

$\mathrm{N}$ : colonial ground nester; open shores or on islands.

Summer resident of the region. Has been found along Little Fish Lake but none were recorded in the Reserve in 1996.

Scolopacidae (Sandpipers, Turnstones and Allies)

Lesser Yellowlegs (Tringa flavipes)

$\mathrm{H}$ : marshy and grassy areas along waterbodies.

$\mathrm{N}$ : no suitable nesting habitat in the Reserve.

Common around the wetlands.

Solitary Sandpiper

$\mathrm{H}$ : meadows, wet fields and muddy shorelines.

$\mathrm{N}$ : no suitable nesting habitat in the Reserve.

Willet (Catoptrophorus semipalmatus)

$\mathrm{H}$ : moist meadows and grassy edges of waterbodies.

$\mathrm{N}$ : semi-colonial ground nester; grassy areas near marshes.

Common in the mixed grassland in the central part of the Reserve, especially around the marsh.

Spotted Sandpiper (Actitis macularia)

$\mathrm{H}$ : found in almost all habitat types; prefers shorelines for foraging.

$\mathrm{N}$ : ground nester;

Common around wetlands and dugouts. 



\section{Upland Sandpiper (Bartramia longicauda)}

$\mathrm{H}$ : open grassy firled with little shrubbery.

$\mathrm{N}$ : ground nester, singly or in small groups; nest well hidden in grass.

Common in denser mixed grasslands, probably as loose colonies. Not often found in dense fescue grasslands. Were common along northwest shore of Little Fish Lake in 1981 but not in 1986, due to heavy cattle grazing. None were found in that area in 1996, no doubt for the same reason.

\section{Long-billed Curlew (Numenius americanus)}

$\mathrm{H}$ : open grasslands with low cover.

$\mathrm{N}$ : ground nester, singly or in loose colonies; in short grass.

Have been recorded in the Reserve but not in 1996, although they were present in the region.

\section{Marbled Godwit (Limosa fedoa)}

$\mathrm{H}$ : grasslands near ponds and sloughs.

$\mathrm{N}$ : ground nester; may be semi-colonial; nest in short grass cover.

Summer resident. One pair defending nest site in open grassland near the marsh.

Sanderling (Calidris alba)

$\mathrm{H}$ : migrant; prefers sandy shores of lakes.

Semipalmated Sandpiper (Calidris pusilla)

$\mathrm{H}$ : migrant.

Least Sandpiper (Calidris minutilla)

$\mathrm{H}$ : migrant; muddy shores of waterbodies and wet fields.

Baird's Sandpiper (Calidris bairdii)

$\mathrm{H}$ : migrant; mud flats of lakes, slough margins.

Pectoral Sandpiper (Calidris melanotos)

$\mathrm{H}$ : wet fields, grassy marshes.

Short-billed Dowitcher (Limnodramus griseus)

$\mathrm{H}$ : migrant; muddy shores of marshes and lakes.

A flock of thirty spent several days along the muddy shore of the marsh.

Long-billed Dowitcher (Limnodromus scolopaceus)

$\mathrm{H}$ : migrant; marshes, damp meadows.

Common Snipe (Gallinago gallinago)

$\mathrm{H}$ : moist meadows, grassy margins of small waterbodies.

$\mathrm{N}$ : ground nester; nests in dense vegetation in wet terrain.

Summer resident. Common in the 1970 's, but not found in 1984, probably due to cattle damage to 

wetlands. Two individuals found at the marsh in 1996.

Wilson's Phalarope (Phalaropus tricolor)

$\mathrm{H}$ : wet meadows and grassy marshes.

$\mathrm{N}$ : ground nester; in wet grassy areas, usually near water.

Summer resident. One male found at the marsh.

\section{Laridae (Gulls)}

Franklin's Gull (Larus pipixcan)

$\mathrm{H}$ : waterbodies, grassy fields and meadows.

$\mathrm{N}$ : nests in large colonies along the marshy shores of lakes.

Ring-billed Gull (Larus delawarensis)

$\mathrm{H}$ : highly variable habitat preferences; fields, waterbodies, mud flats.

$\mathrm{N}$ : nest in large colonies on islands.

California Gull (Larus californicus)

$\mathrm{H}$ : highly variable habitat preferences; fields, waterbodies, mud flats.

$\mathrm{N}$ : nests on islands in lakes.

Herring Gull (Larus argentatus)

$\mathrm{H}$ : fields and waterbodies.

$\mathrm{N}$ : nests on islands.

Were commonly seen flying over the Reserve.

Common Tern (Sterna hirundo)

$\mathrm{H}$ : forages over sloughs, lakes and creeks.

$\mathrm{N}$ : ground nester; usually on a gravelly or sandy beach; occasionally in marshes.

Used to nest on small islands in Little Fish lake but does no longer due to low water levels.

Black Tern (Chlidonias niger)

$\mathrm{H}$ : lakes, marshes, ponds and wet meadows.

$\mathrm{N}$ : usually colonial nesters, sometimes singly; floating nest is anchored to emergent vegetation.

Summer visitor.

Columbidae (Pigeons and Doves)

Rock Dove (Columba livia)

$\mathrm{H}$ : found in a variety of dry habitats.

$\mathrm{N}$ : nests in man-made structures.

Occasionally seen flying over the Reserve. 



\section{Mourning Dove (Zenaida macroura)}

$\mathrm{H}$ : aspen groves, coulees, grasslands.

$\mathrm{N}$ : nests in trees, shrubs or on the ground, always in the vicinity of water.

Occasionally seen along the wooded coulees.

\section{Cuculidae (Cuckoos)}

Black-billed Cuckoo (Coccyzus erythropthalmus)

$\mathrm{H}$ : dense shrubbery of coulees or open woodlands with dense shrubs;

$\mathrm{N}$ : usually nests in dense shrubs.

\section{Strigidae (Owls)}

Great-horned Owl (Bubo virginianus)

$\mathrm{H}$ : wooded coulees, aspen groves.

$\mathrm{N}$ : uses abandoned stick nests of hawks or crows.

Summer resident. Nests have been found in the coulees and aspen copses.

\section{Burrowing Owl (Athene cunicularia)}

$\mathrm{H}$ : open grasslands with low grass cover.

$\mathrm{N}$ : singly or in colonies; nests in abandoned ground squirrel or badger burrows.

None were recorded in the Reserve.

\section{Short-eared Owl (Asio flammeus)}

$\mathrm{H}$ : grasslands, shrubby meadows, marshlands.

$\mathrm{N}$ : ground nester; nest well hidden by dense grass or reeds.

Summer visitor.

\section{Caprimulgiformes (Nightjars)}

\section{Common Nighthawk (Chordeiles minor)}

$\mathrm{H}$ : open habitat such as grasslands and wide lake beaches

$\mathrm{N}$ : ground nester; on sand or gravel areas.

\section{Picidae (Woodpeckers)}

Hairy Woodpecker (Picoides villosus)

$\mathrm{H}$ : deciduous groves, often near meadows and open areas.

$\mathrm{N}$ : cavity nester, in deciduous trees. 

Northern Flicker (Colaptes auratus)

$\mathrm{H}$ : deciduous woods, shelter belts.

$\mathrm{N}$ : cavity nester, in deciduous trees.

Commonly seen in the aspen copses.

\section{Tyrannidae (Flycatchers)}

Western Wood-Peewee (Contopus sordidulus)

$\mathrm{H}$ : wooded coulees.

$\mathrm{N}$ : deciduous trees, only in wooded coulees.

Least Flycatcher (Empidonax minimus)

$\mathrm{H}$ : deciduous groves in coulees.

$\mathrm{N}$ : deciduous trees.

Summer resident in the aspen copses.

Western Kingbird (Tyrannus verticalis)

$\mathrm{H}$ : open grasslands, usually near trees or perches such as fenceposts.

$\mathrm{N}$ : nests in shrubs or trees.

Summer resident in the aspen copses. Both adults and juveniles recorded.

Eastern Kingbird (Tyrannus tyrannus)

$\mathrm{H}$ : open fields with scattered trees; wooded coulees.

$\mathrm{N}$ : deciduous trees or shrubs, usually near water.

Commonly seen in aspen copses and along wooded coulees.
Alaudidae (Larks)
Horned Lark (Eremophila alpestris)
$\mathrm{H}$ : open habitat such as grasslands.
$\mathrm{N}$ : ground nester; on the prairie, nest is usually near a dense clump of grass.
Common. Most were seen in the area around the marsh but were occasionally recorded in scattered parts of the Reserve.

\section{Hirundinidae (Swallows)}

\section{Tree Swallow (Tachycineta bicolor)}

$\mathrm{H}$ : variable; open habitats.

$\mathrm{N}$ : cavity nester, in abandoned woodpecker holes or nestboxes.

Seen aling the shoreline of Little Fish Lake. The fenceline along the shore has several swallow nest boxes on it, some with evidence of recent nesting. 

Northern Rough-winged Swallow (Stelgidopteryx serripennis)

$\mathrm{H}$ : open fields, generally near water.

$\mathrm{N}$ : ground nester, in soft earth of steeper embankments.

Summer resident in the region.

Cliff Swallow (Hirundo pyrrhonota)

$\mathrm{H}$ : open fields and marshes.

$\mathrm{N}$ : vertical surfaces such as cliffs; there is probably no suitable nesting sites within the Reserve.

Summer resident in the region.

Barn Swallow (Hirundo rustica)

$\mathrm{H}$ : open areas, preferably in the vicinity of wetlands with muddy shores.

$\mathrm{N}$ : vertical surfaces such as cliffs; there is probably no suitable nesting sites within the Reserve.

Seen flying over the corral in the central part of the Reserve.

Corvidae (Magpies and Crows)

Black-billed Magpie (Pica pica)

$\mathrm{H}$ : found in all habitat types.

$\mathrm{N}$ : large stick nests in trees or tall shrubs.

Common, especially in the coulees. Two family groups seen; one in a coulee, the other in the poplars along the shoreline of Little Fish lake (where several stick nests are present). Nests also found in coulees.

American Crow (Corvus brachyrhynchos)

$\mathrm{H}$ : forages in open habitats; roosts in treed areas, such as wooded coulees.

$\mathrm{N}$ : stick nests in trees or large shrubs.

Common summer resident. A few stick nests were found. A single large (three meters) willow shrub, which was quite isolated from any other shrubbery, contained three crow nests.

Paridae (Chickadees)

Black-capped Chickadee (Parus atricapillus)

$\mathrm{H}$ : deciduous groves.

$\mathrm{N}$ : cavity nester, in deciduous trees.

Resident in the coulees.

Sittidae (Nuthatches)

Red-breasted Nuthatch (Sitta canadensis)

$\mathrm{H}$ : coniferous and mixed-woods.

$\mathrm{N}$ : cavity nester, in trees.

Summer visitor. Occasionally recorded in the aspen clones. 

White-breasted Nuthatch (Sitta carolinensis)

$\mathrm{H}$ : mature deciduous and mixed-woods.

$\mathrm{N}$ : cavity nester, in trees.

Summer visitor.

\section{Troglodytidae (Wrens)}

House Wren (Troglodytes aedon)

$\mathrm{H}$ : open woodlands, coulees.

$\mathrm{N}$ : cavity nester, generally in trees and large shrubs.

Summer resident in the wooded coulees. Occasionally heard singing in dense shrubbery.

Muscicapidae (Thrushes and Allies)

Ruby-crowned Kinglet (Regulus calendula)

$\mathrm{H}$ : coniferous woods.

Probably a rare summer visitor.

Mountain Bluebird (Sialia currucoides)

$\mathrm{H}$ : mixed woodlands and grasslands.

$\mathrm{N}$ : cavity nesters, in tree holes and nest boxes.

Probably nests in nearby badlands.

Gray-cheeked Thrush (Catharus minimus)

$\mathrm{H}$ : migrant

Swainson's Thrush (Catharus ustulatus)

$\mathrm{H}$ : migrant

American Robin (Turdus migratorius)

$\mathrm{H}$ : open fields in the vicinity of woodlands and/or tall shrubs.

$\mathrm{N}$ : in trees or shrubs.

Commonly seen in woodlands; either the aspen copses or wooded coulees.

Mimidae (Mockingbirds and Thrashers)

Gray Catbird (Dumetella carolinensis)

$\mathrm{H}$ : dense shrubbery of coulees.

$\mathrm{N}$ : in dense shrubs, near the ground.

Commonly heard in tall dense shrubbery of the coulees. 

Brown Thrasher (Toxostoma rufum)

$\mathrm{H}$ : tall shrubbery of coulees.

$\mathrm{N}$ : in dense shrubs, within one meter of the ground.

Summer resident in the tall coulee shrubbery.

\section{Motacillidae (Pipits)}

\section{American Pipit (Anthus rubescens)}

$\mathrm{H}$ : migrant

\section{Sprague's Pipit (Anthus spragueii)}

$\mathrm{H}$ : bushy grassland.

$\mathrm{N}$ : ground nester, in dense grass.

Common summer resident. May be the most common bird in the reserve.

\section{Bombycillidae (Waxwings)}

\section{Cedar Waxwing (Bombycilla cedrorum)}

$\mathrm{H}$ : prefers edge habitat of deciduous woodlands and dense shrubbery.

$\mathrm{N}$ : in trees or tall shrubs.

Summer resident in tall coulee shrubbery. One nest with young found.

\section{Lanidae (Shrikes)}

\section{Loggerhead Shrike (Lanius ludovicianus)}

$\mathrm{H}$ : wooded coulees; open grasslands with scattered trees or tall shrubs.

$\mathrm{N}$ : in trees or tall shrubs.

Summer resident. Often seen around the aspen copses; and in open grasslands, flying between widely scattered tall shrubs.

\section{Sturnidae (Starlings)}

European Starling (Sturnus vulgaris)

$\mathrm{H}$ : open habitats, such as fields.

$\mathrm{N}$ : cavity nester, in trees or nest boxes.

Occasional summer visitor.

\section{Vireonidae (Vireos)}

Warbling Vireo (Vireo gilvus)

$\mathrm{H}$ : aspen groves, generally near water.

$\mathrm{N}$ : in tall trees, occasionally in tall shrubs.

Common in the aspen copses. Also found in the wooded coulees. 

Red-eyed Vireo (Vireo olivaceus)

H: open deciduous woodlands, tall shrubbery, wooded coulees.

$\mathrm{N}$ : deciduous trees, occasionally tall shrubs, usually near the edge of groves.

Common in the aspen copses and wooded coulees.

Emberizidae (Wood Warblers, Tanagers and Allies)

Orange-crowned Warbler (Vermivora celata)

$\mathrm{H}$ : migrant. Summer visitor.

Yellow Warbler (Dendroica petechia)

$\mathrm{H}$ : tall shrubbery and deciduous woods.

$\mathrm{N}$ : nests in deciduous trees or tall shrubs.

Common in coulee woodlands and shrubbery and the aspen copses.

Yellow-rumped Warbler (Dendroica coronata)

$\mathrm{H}$ : migrant. Summer visitor

Blackpoll Warbler (Dendroica striata)

$\mathrm{H}$ : migrant. Summer visitor.

Common Yellowthroat (Geothlypis trichas)

$\mathrm{H}$ : tall shrubbery, open marshy areas, beaver ponds.

$\mathrm{N}$ : nests in dense shrubs over or near water.

Occasional in the dense low shrubbery along the beaver ponds.

Rufous-sided Towhee (Pipilo erythrophthalmus)

$\mathrm{H}$ : edges of aspen groves, shrubbery of coulees.

$\mathrm{N}$ : in dense, low shrubs; on or just above the ground.

Summer resident in the tall coulee shrubbery.

American Tree Sparrow (Spizella arborea)

$\mathrm{H}$ : migrant. Summer visitor.

Chipping Sparrow (Spizella passerina)

$\mathrm{H}$ : open deciduous woods, adjacent to open fields.

$\mathrm{N}$ : shrubs and small trees.

May nest in the Reserve.

Clay-colored Sparrow (Spizella pallida)

$\mathrm{H}$ : tall shrubbery, shrubby grasslands.

$\mathrm{N}$ : dense shrubs or small trees.

Summer resident throughout much of the Reserve. 



\section{Vesper Sparrow (Pooecetes gramineus)}

$\mathrm{H}$ : grasslands.

$\mathrm{N}$ : ground nester; well-hidden in dense grass or under small shrubs.

Common summer resident. Nests found in mixed grasslands.

\section{Lark Sparrow (Chondestes grammacus)}

$\mathrm{H}$ : semi-open grasslands, especially in coulees and badland habitats.

$\mathrm{N}$ : ground nester; usually beneath a small shrub or grass tuft.

\section{Lark Bunting (Calamospiza melanocorys)}

$\mathrm{H}$ : dry grasslands, especially in the vicinity of sagebrush.

$\mathrm{N}$ : ground nester.

\section{Savannah Sparrow (Passerculus sandwichensis)}

$\mathrm{H}$ : edge habitat of meadows, moist grasslands and sloughs.

$\mathrm{N}$ : ground nester; concealed under grass or sedges.

Commonly recorded over much of the Reserve but mainly in tall grasslands.

\section{Baird's Sparrow (Ammodramus bairdii)}

$\mathrm{H}$ : ungrazed or lightly grazed dense grassland with patches of small shrubs.

$\mathrm{N}$ : ground nester; in tall grass, often beneath a shrub or grass tuft.

Summer resident. Found only in dense fescue grasslands.

\section{LeConte's Sparrow (Ammodramus leconteii)}

$\mathrm{H}$ : tall grasses along sloughs; shrubby habitat along creeks.

$\mathrm{N}$ : ground nester; in moist habitat.

Summer visitor, possibly resident.

\section{Song Sparrow (Melospiza melodia)}

$\mathrm{H}$ : shrubby woodlands, shrubby margins of sloughs, aspen groves.

$\mathrm{N}$ : ground nester; sometimes nests in shrubs; nests well concealed beneath vegetation.

Only one recorded in the Reserve.

White-throated Sparrow (Zonotrichia albicollis)

$\mathrm{H}$ : deciduous woodlands, especially edge habitat.

$\mathrm{N}$ : ground nester; along forest edges, usually in shrubbery.

Probably just a summer visitor.

\section{Harris' Sparrow (Zonotrichia querula)}

$\mathrm{H}$ : migrant. Summer visitor.

Dark-eyed Junco (Junco hyemalis)

$\mathrm{H}$ : migrant. Summer visitor. 

McCown's Longspur (Calcarius mccownii)

$\mathrm{H}$ : dry short-grass prairie; prefers moderately to heavily grazed sites.

$\mathrm{N}$ : ground nester; usually at base of shrub or grass tuft.

Lapland Longspur (Calcarius lapponicus)

$\mathrm{H}$ : migrant. Summer visitor.

Smith's Longspur (Calcarius pictus)

$\mathrm{H}$ : migrant. Summer visitor.

Chestnut-collared Longspur (Calcarius ornatus)

$\mathrm{H}$ : mixed grassland, with moderate to heavy grazing.

$\mathrm{N}$ : ground nester; often in open, sparse grass.

Has been recorded as a summer resident. None observed in mid-1980's or in 1996.

Red-winged Blackbird (Agelaius phoeniceus)

$\mathrm{H}$ : cattails and bulrushes surrounding open water; tall shrubs nest to water; forages in dry fields.

$\mathrm{N}$ : in thick emergent vegetation nest to water.

Summer resident, near wetlands and along the shoreline of Little Fish lake.

Western Meadowlark (Sturnella neglecta)

$\mathrm{H}$ : grasslands with thick grass.

$\mathrm{N}$ : ground nester;

Common summer resident. One of the most common birds in the Reserve. Found in all grassland types except those which were heavily grazed.

Yellow-headed Blackbird (Xanthocephalus xanthocephalus)

$\mathrm{H}$ : sloughs, marshes and lake margins with dense emergent vegetation.

$\mathrm{N}$ : nests in dense cattails or bulrushes over water.

Occasionally seen around the marsh.

Brewer's Blackbird (Euphagus cyanocephalus)

$\mathrm{H}$ : variable; open fields, grasslands with scattered shrubs, aspen groves.

$\mathrm{N}$ : variable; in low bushes or on the ground, usually close to water.

Occasionally seen at wetlands.

Common Grackle (Quiscalus quiscula)

$\mathrm{H}$ : open habitat such as fields, shorelines of lakes, marshes.

$\mathrm{N}$ : shrubbery, marsh vegetation. 

Brown-headed Cowbird (Molothrus ater)

$\mathrm{H}$ : widely variable;

$\mathrm{N}$ : parasitic breeder (egg dumper).

Summer resident.

Northern Oriole (Icterus galbula)

$\mathrm{H}$ : tall deciduous trees, usually near edge habitat.

$\mathrm{N}$ : in deciduous trees.

Summer resident in woodlands of coulees and aspen copses.

Fringillidae (Finches)

Pine Grosbeak (Pinicola enucleator)

$\mathrm{H}$ : migrant. Summer visitor

Red Crossbill (Loxia curvirostra)

$\mathrm{H}$ : migrant. Summer visitor.

Pine Siskin (Carduelis pinus)

$\mathrm{H}$ : migrant. Summer visitor.

American Goldfinch (Carduelis tristis)

$\mathrm{H}$ : weedy grasslands, usually near fencerows or roadsides.

$\mathrm{N}$ : deciduous trees or shrubs.

Commonly recorded in grasslands around the aspen copses and in the coulees.

Passeridae (Weaver Finches)

House Sparrow (Passer domesticus)

$\mathrm{H}$ : found mainly associated with human habitation.

$\mathrm{N}$ : usually in man-made structures, sometimes in tree cavities. 



\section{Appendix VI Annotated List of the Mammals}

The following information on the mammals of the Reserve was taken from Smith (1993), Wallis and Wershler (1985) and supplemented by field notes.

\section{Soricidae (Shrews)}

Masked Shrew (Sorex cinereus): common; variety of habitats, including damp meadows and deciduous woods.

Prairie Shrew (Sorex haydeni): uncommon; shrubby areas, meadows, dense vegetation.

Dusky Shrew (Sorex monticolus): uncommon; variety of habitats, from damp meadows to dry grasslands, most frequantly in dense cover.

\section{Vespertilionidae (Bats)}

Little Brown Bat (Myotis lucifugus): common; may occur in area due to nearby presence of abandoned farm buildings.

Silver-haired Bat (Lasionycteris noctivagans): common; a woodland species, it may use the aspen clones for roosting sites.

Big Brown Bat (Eptesicus fuscus): relatively common; may occur in area due to nearby presence of abandoned farm buildings.

Hoary bat (Lasiurus cinereus): relatively common; may use aspen clones for roosting sites.

Leporidae (Hares and Rabbits)

Nuttall's Cottontail (Sylvilagus nuttallii): common; grassland areas with patches of buckbrush and wolf willow. Not recorded in the coulees

White-tailed Jack Rabbit (Lepus townsendii): common; open grasslands. Most commonly seen in grazed grasslands.

Sciuridae (Groundsquirrels)

Least Chipmink (Tamias minimus): common; treed areas in the aspen clones, and areas of poplar and shrubs along the shoreline of Little Fish Lake. The Reserve is at the southern range of this species in eastern Alberta. Recorded in coulee shrubbery.

Richardson's Ground Squirrel (Spermophilus richardsonii): common; found most often on heavily grazed grasslands, disturbed areas or along the escarpment. Can be especially numerous in overgrazed lands. 

Thirteen-lined Ground Squirel (Spermophilus tridecemlineatus): sporadic to common; found in ungrazed or mowed grasslands; also occur around shrubby areas, such as patches of buckbrush and wolf willow. Less common in 1984 than in 1970. Not found in 1996.

Geomyidae (Pocket Gophers)

Northern Pocket Gopher (Thomomys talpoides): probably scarce to uncommon; native grasslands. Found in fescue grassland in 1977, a range extension from its currently listed distribution.

Castoridae (Beavers)

Beaver (Castor canadensis): sloughs and creeks with easy access to trees.

Cricetidae (Mice, Voles)

Deer Mouse (Peromyscus maniculatus): very common; likely occurs in all habitat types within the Reserve.

Northern Grasshopper Mouse (Onychomys leucogaster): relatively common; open grassland areas with sagebrush. The Reserve is at the northern eddge of its range in Alberta.

Southern Red-backed Vole (Clethrionomys gapperi): abundant; if found within the Reserve, they would occur in and around the aspen clones. The Reserve is at the southern edge of their range in Alberta.

Meadow Vole (Microtus pennsylvanicus): common; open grasslands, especially depressional areas, moist meadows along drainage features and grassy coulee bottoms.

Sagebrush Vole (Lagurus curtatus): uncommon; grassland areas where sagebrush is common.

Muskrat (Ondatra zibethicus): probably rare; the only place within the Reserve where it might be found is in the marsh near the north-west shore of Little Fish lake.

Muridae (House Mouse)

House Mouse (Mus musculus): unlikely to occur within the Reserve but may be present around the corral in the center of the Reserve (there is an abandoned trailer located there).

\section{Zapodidae (Jumping Mouse)}

Western Jumping Mouse (Zapus princeps): common; drainage features with a shrubby or meadow vegetation cover, or around the aspen clones.

Erethizontidae (Porcupines)

Porcupine (Erithizon dorsatum): treed areas and riparian woods. A young one was found in a naerby aspen clone in 1970 . 



\section{Canidae (Carnivores)}

Coyote (Canis latrans): relatively common; would occur in all habitat types. Present throughout the area. Has been known to den in the vicinity.

Red Fox (Vulpes vulpes): common; would occur in all habitat types.

\section{Mustelidae (Weasels)}

Ermine (Mustela erminea): scarce; if it occurs within the Reserve it would only be around the aspen clones.

Least Weasel (Mustela nivalis): common; would probably be found in all habitat types.

Long-tailed Weasel (Mustela frenata): Would probably be found in all habitat types. Recorded in vicinity of ground squirrel colonies in the Reserve. Populations of this species may be in decline but this has not yet been confirmed (Smith 1993).

Mink (Mustela vison): common; probably only found around the marsh area, coming into the Reserve from Little Fish Lake.

Badger (Taxidea taxus): relatively common; open grasslands everywhere within the Reserve, with the exception of the coulees. Not recorded in 1984 or 1996 but has been found previously in heavily grazed areas with solonetzic soils.

Striped Skunk (Mephitis mephitis): common; likely found throughout the Reserve.

\section{Cervidae (Deer)}

Mule Deer (Odocoileus emionus): common; recorded throughout the Reserve. Regularly seen in coulees and shrubby uplands.

White-tailed Deer (Odocoileus virginianus): common; prefers areas with tree cover, such as that around the aspen clones.

\section{Antilocapridae (Pronghorn)}

Pronghorn (Antilocapra americana): common; open grasslands throughout the Reserve. Seen most frequently along the southern highlands. 



\section{Appendix VII Annotated List of the Butterflies}

This information was taken mainly from Bird et al (1995), with some additional information from Acorn (1993). Flight times are average periods and may vary from year to year, depending on, among other factors, the season's weather.

\section{Hesperiidae (Skippers)}

Delaware Skipper (Atrytone logan): shrubby ravines and coulees; flies from the first week of May until the first week of August.

Common Branded Skipper (Hesperia comma assiniboia): prairies and grassy vally sides; flies in August and September.

Nevada Skipper (Hesperia nevada): fescue grassland, usually on ridge tops and hillsides; flies from early June to mid-August.

Uncas Skipper (Hesperia uncas): valleys and coulees of mixed-grass prairie; flies from the end of May until mid-August.

Garita Skipper (Oarisma garita): fescue and mixed-grass prairies; flies during June and July.

Long Dash Skipper (Polites mystic): meadows and weedy areas in the prairie region; flies from the end of May until the end of August.

Peck's Skipper (Polites peckius): grasslands and weedy areas; flies from the first week in June until the end of August.

Tawny-edged Skipper (Polites themistocles): moist grasslands and along streams; flies from midJune until the end of August.

Arctic Skipper (Carterocephalus palaemon): meadows; flies from the start of May until the first week of August.

Silverspotted Skipper (Epargyreus clarus): along streams and in coulees; flies from the beginning of May until the end of July.

Afranius Duskywing (Erynnis afranius): native grasslands, especially along creeks and in uplands; flies from mid-May until the end of September.

Dreamy Duskywing (Erynnis icelus): along prairie streams; flies from the start of May until midJuly. 

Persius Duskywing (Erynnis persius): uncommon and local on the prairies; meadows and river valleys; flies from first week of May until mid-August.

Checkered Skipper (Pyrgus communis): grasslands; flies from mid-May to mid-September.

\section{Papilionidae (Swallowtails)}

Anise Swallowtail (Papilio zelicaon): prairie hilltops; flies from end of April until mid-August.

Canadian Tiger Swallowtail (Papilio canadensis): rare and localized in grasslands; flies from midMay to mid-August.

Pieridae (Whites, Marbles and Sulphurs)

Cabbage Butterfly (Pieris rapae): common in nearby agricultural fields but are only found in undisturbed grasslands as straying migrants; flies from the first week of April until the end of October.

Western White (Pontia occidentalis): meadows and grassy roadsides; flies from beginning of May until the end of September.

Olymipia Marble (Euchloe olympia): native grasslands; flies from the start of May until mid-July.

Alexandra Sulphur (Colias alexandra): grasslands; has two generations, one in June/July and a second in August.

Christina Sulphur (Colias christina): fescue grasslands; flies from mid-May until the end of September.

Alfalfa Butterfly (Cloias eurytheme): open areas, especially clover and alfalfa fields; flies from the beginning of June until the latter part of September.

Clouded Sulphur (Colias philodice): open habitat, especially along roadsides; flies from mid-May until mid-September.

\section{Lycaenidae (Gossamer Wings)}

Purplish Copper (Lycaena helloides): prairie grasslands, often around wetland margins; flies from mid-May until the first week of October.

Great Gray Copper (Lycaena dione): moist areas around ponds and streams where Rumex spp. occur; flies from mid-June to mid-September. 

Bronze Copper (Lycaena hyllus): margins of wetlands where Rumex and Polygonum spp. occur; flies in July and August.

Coral Hairstreak (Harkenclenus titus): in coulees where Choke Cherry (Prunus virginiana) and Saskatoon (Amelanchier alnifolia) occur; flies from the beginning of June to the end of September.

Acadian Hairstreak (Satyrium acadicum): moist areas, and Salix thickets around wetlands; flies in July and August.

Striped hairstreak (Satyrium liparops): this species requires patches of Choke Cherry (Prunus virginiana) at heads of ravines and coulees; flies from mid-June until the first part of August.

Gray Hairstreak (Strymon melinus): found mainly in badlands but may occur within the Reserve; flies from mid-May until mid-August.

Spring Azure (Celastrina ladon): associated with Red-Osier Dogwood (Cornus stolonifera) in coulees; flies from the first week in April until the first part of July.

Western Tailed Blue (Everes amyntula): areas with legumes, generally near deciduous trees; flies from mid-May until the first part of August.

Silvery Blue (Glaucopsyche lygdamus): variety of legumes, near aspen trees; flies from the beginning of April until mid-August.

Mellissa Blue (Lycaeides melissa): coulees; flies from mid-May until mid-September.

Rustic Blue (Plebejus rusticus): hillsides and gullies; flies from the first part of May until midSeptmber.

Acmon Blue (Plebejus acmon): prairie grasslands; flies from mid-May until mid-August.

Shasta Blue (Plebejus shasta): along steep, sparsely vegetated hills; flies in July and August.

Greenish Blue (Plebejus saepiolus): found in the vicinuity of clovers and other legumes; flies from mid-May until mid-August.

Nymphalidae (Anglewings, Fritillaries and allies)

Milbert's Tortoise Shell (Aglais milberti): uncommon on the prairies; prefers habitat with Salix, goldenrod and thistles; flies from the start of April until the end of October.

Mourning Cloak (Nymphalis antiopa): along riparian forests and wetland margims with Willow (Salix spp) and Poplars (Populus spp); flies from the beginning of April until the end of October. 

Red Admiral (Vanessa atalanta): variety of habitat types but most often along creeks and in meadows; uncommon; flies from the first week of May until mid-October.

Painted Lady (Vanessa cardui): found in virtually every non-wetland habitat type; flies from the third week in April until the end of October.

Meadow Fritillary (Boloria bellona): meadows and open grasslands; flies from mid-May until the end of September.

Variegated Fritillary (Euptoieta claudia): meadows and grasslands; flies from the beginning of June until mid-October.

Aphrodite Fritillary (Speyeria aphrodite): native prairie grasslands; flies from mid-June until the end of August.

Northwestern Fritillary (Speyeria electa): habitat type used not well known; flies from the last week in May until the end of September.

Callippe Fritillary (Speyeria callippe): near hilltops; flies from mid-June until mid-September.

Great Spangled Fritillary (Speyeria cybele): prairie coulees, meadows and the edges of pasture land; flies from mid-June until the first part of September.

Edwards' Fritillary (Speyeria edwardsii): habitat type used not well known; flies from the beginning of June until mid-September.

Mormon Fritillary (Speyeria mormonia): prairie grasslands; flies from the start of June until the end of September.

Acastus Checkerspot (Charidryas acastus): badland-type terrain along coulees; flies from the beginning of May until the first part of September.

Gorgone Checkerspot (Charidryas gorgone): open areas, primarily prairie grasslands; seldom abundant; flies from the first week in May until mid-July.

Tawny Crescent (Phyciodes batesii): mesic sites in shrubby coulee habitat; flies from first part of June until the end of July.

Northern Pearl Crescent (Phyciodes cocyta): moist grasslands near trees; not widespread in the prairies but may occur in the Hand Hills; flies from mid-May until the end of August.

Pearl Crescent (Phyciodes tharos): widespread in prairie grasslands, especially in coulees with bushy habitat; flies from the beginning of May until the end of August. 

Viceroy (Limenitis archippus): open areas and meadows, usually in the vicinity of Salix sp., Populus sp. or Prunus sp.; flies from mid-June until mid-August.

White Admiral (Limenitis arthemis): areas with deciduous trees; flies from the end of May until midSpetember.

Satyridae (Satyrs, Wood Nymphs and allies)

Dark Wood Nymph (Cercyonis oetus): common in grasslands; flies from the beginning of June until mid-September.

Common Wood Nymph (Cercyonis pegala): common in grasslands; flies from mid-June until the first part of September.

Inornate Ringlet (Coenonympha inornata): common in grasslands; flies from mid-May until the end of October.

Common Alpine (Erebia epipsodea): moist meadows with lush grass; flies from the first part of May until mid-October.

Alberta Arctic (Oeneis alberta): natural short- and mixed-grass prairie habitats; may be abundant on hilltops; flies from mid-April until the first week of July.

Uhler's Arctic (Oeneis uhleri): found primarily in Festuca and Stipa grasslands; flies from the beginning of May until the end of August.

Ridings' Satyr (Neominois ridingsii): native fescue (Festuca sp.) and mixed-grass prairies, usually near coulees; flies from mid-June until the last part of August.

Danaidae (Milkweed Butterflies)

Monarch (Danaus plexippus): probably only found in the Reserve as a migrant; flies from the beginning of June until the end of Spetember. 



\section{Appendix VIII Reserve History and Administrative Land Use}

The following is a brief history of the area which has become the Hand Hills Ecological Reserve. These milestones mark the evolution of this area from a near-anonymous piece of prairie landscape to an important member of the family of Ecological Reserves in Alberta.

Starting in the mid-1970's, the Alberta Wilderness Association had advocated some form of protection for the area around Little Fish lake.

April 1981: the Hand Hills are identified, along with five other sites, as a potential Ecological Reserve representing the Northern Fescue grassland.

October 1983: Alberta Recreation and Parks officially requested a ten section reservation for the area immediately west of Little Fish lake.

June 1984: Alberta Energy and Natural Resources issued a contract to study the natural features of the area around Little Fish lake.

November, 1984: the Verdant Valley Ranch was issued a ten year continuation of its grazing lease. This lease covered most of the area being considered for potential designation as an Ecological Reserve.

November 15, 1984: the Ecological Reserves Coordinating Committee recommended a four square mile area for Ecological Reserve status. This parcel of land included section 15 and portions of sections $9,10,11,14,16$ and 22, of Range 17 . Thus, it covered only the western and southwestern portions of what eventually became the Reserve. As well, it included lands to the west of the current western boundaries. The rational for this selection was that, while it contained fewer extensive fescue grasslands than is now the case, there was greater topographic variation and, possibly, greater overall biodiversity.

December 4, 1984: the entire holdings of the Verdant Valley Ranch (18,483 acres; 6417 deeded and 12066 crown) were sold at auction. This resulted in eight different grazing lessees where before there was just the single one. Three of these leases were within the area being considered as an Ecological Reserve. The Alberta Wilderness Association was present at the auction and informed the new lessees that the area was under consideration as an Ecological Reserve.

December 18, 1984: the Ecological Reserves Coordinating Committee (ERCC) met to discuss the potential problems associated with the increased number of grazing lessees within the proposed Reserve.

1985: the first detailed biophysical study of the proposed Reserve area was completed, for Alberta Energy and Natural Resources. (Wallis, C. and C. Wershler. 1985. Little Fish Lake resource 

assessment.).

February 1985: the Ministers of Environment and of Recreation and Parks endorsed the original ten section area as an Ecological Reserve.

August 1986: a second biophysical study of the Reserve area was completed for Alberta Recreation and Parks. (Cottonwood Consultants Ltd. 1986. The proposed Hand Hills Ecological Reserve. A biophysical overview.).

September 1986: meetings were held between the lessees within the proposed Ecological Reserve and government staff.

October 15, 1986: a public Notice of Intention to establish the Hand Hills Ecological Reserve was published in the local newspapers.

October 23, 1986: an open house information session was held at the Hand Hills Hall to solicit public input about the proposed Ecological Reserve.

January 14, 1988: the Hand Hills Ecological Reserve was established through an Order-in-Council.

1988: a Planning Team for the Reserve was established, chaired by staff of the Alberts Parks Service (Southern Region).

1988: a detailed study of the Piping Plovers within the proposed Reserve was completed at the request of several agencies (i.e. Alberta Recreation and Parks, World Wildlife Fund, Alberta Fish and Wildlife Division and the Canadian Wildlife Service). (Wershler, C. 1988. Monitoring of Piping Plover Habitat and Land Use at Little Fish Lake, Alberta).

July 7, 1988: the ERCC confirmed a policy whereby grazing would continue within the Reserve. However, a proviso stated that the extent and level of grazing was to be controlled.

November 1988: Fish and Wildlife Division initiated a process to protect the sensitive breeding habitat of the Piping Plover along the shore of Little Fish Lake from damage caused by cattle. The program called for the construction of fences along the embankment of Little Fish lake, and the placement of dugouts within the Reserve.

December 1988: the first draft of a Terms of Reference for a Management Plan was prepared. This Terms of Reference was endorsed by both the Planning Team and the local lessees in April, 1989.

August 1989: the ERCC approved the Terms of Reference.

1990: a survey of the Fescue grasslands within the Hand Hills was completed for the Nature Conservancy of Canada. (Wallis, C. 1990. Hand Hills Fescue Grassland. Biophysical overview.) 

February 1990: the first draft management plan for the Reserve was pepared, and submitted for review in June, 1990. It was endorsed by the local lessees.

February 1990: an ecological survey of the Northern Fescue grassland, which included lands within the Reserve, was completed for Alberta Forestry, Lands and WIldlife. (Sweetgrass Consultants Ltd. 1990. Survey and evaluation of Northern Fescue grassland in Alberta - 1989.).

Summer 1990: fences were constructed around those portions of the shore of Little Fish Lake which are located within the Reserve.

May 1992: second draft of the management plan was prepared and submitted for review. The ERCC reviewed the plan in August, 1992.

February 1993: the first "State-of-the-Reserve" report was prepared by the ERCC, for the year 1992.

March 1993: the ERCC asked the planning team to give lessees at the Reserve an opportunity to review and comment on a revised Draft Management Plan.

November 1993: all lessees within the Reserve were sent a copy of the Draft Management Plan and invited to provide comments.

November 1993: a formal request for a biophysical inventory of the Reserve was submitted by Alberta Parks Service to the Resource Information Division of Alberta Forestry, Lands and Wildlife.

January 1994: the lessee review of the Draft Management Plan, which was arranged by personnel from Special Areas and Public Lands, was finished.

February 1995: a second request for a biophysical inventory of the Reserve was submitted by Alberta Parks Service to the Resource Information Division.

June 1996: field work for a biophysical inventory, range inventory and significant features assessment was begun.

July 1996: the fourth Draft Management Plan for the Reserve was completed.

October 1996: the Prairie Environmental Resource Committee approved the Draft Management Plan, subject to the completion of several editorial changes and administrative procedures. 



\section{Appendix IX Plates}

The reserve is a highly diverse area, in terms of both biotic and abiotic features. To provide the reader with a clearer picture of what the Reserve and its features, the following photographs are provided. 



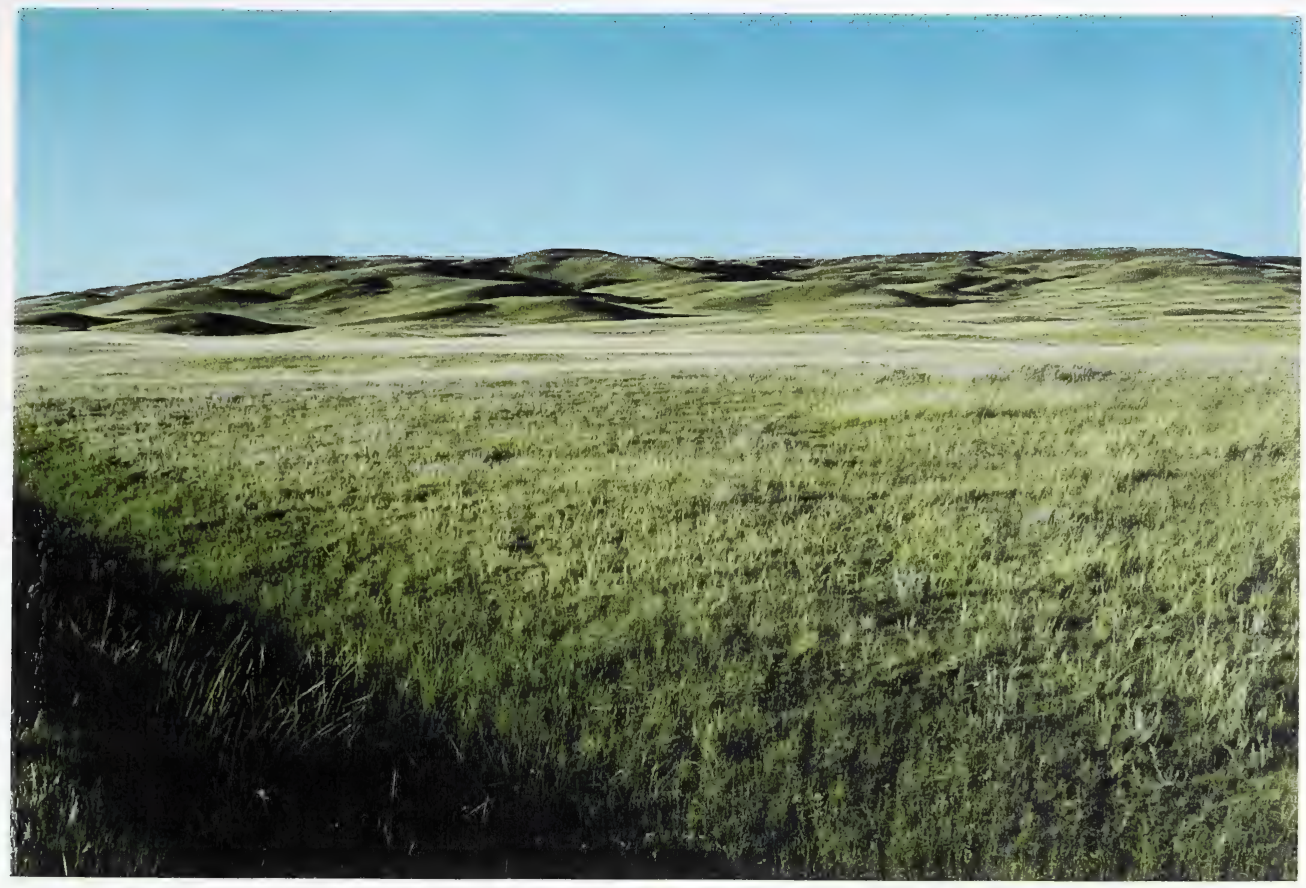

Plate 1 - The escarpment in the south-west corner of the Reserve, as seen from secondary highway 573. The topography in the foreground is typical of the landscape surrounding the Hand Hills plateau. The high point in the reserve, Thumb Hill, is on the skyline in the left of the photo. Plate 2 was taken from that spot, looking back to where this photo was taken.

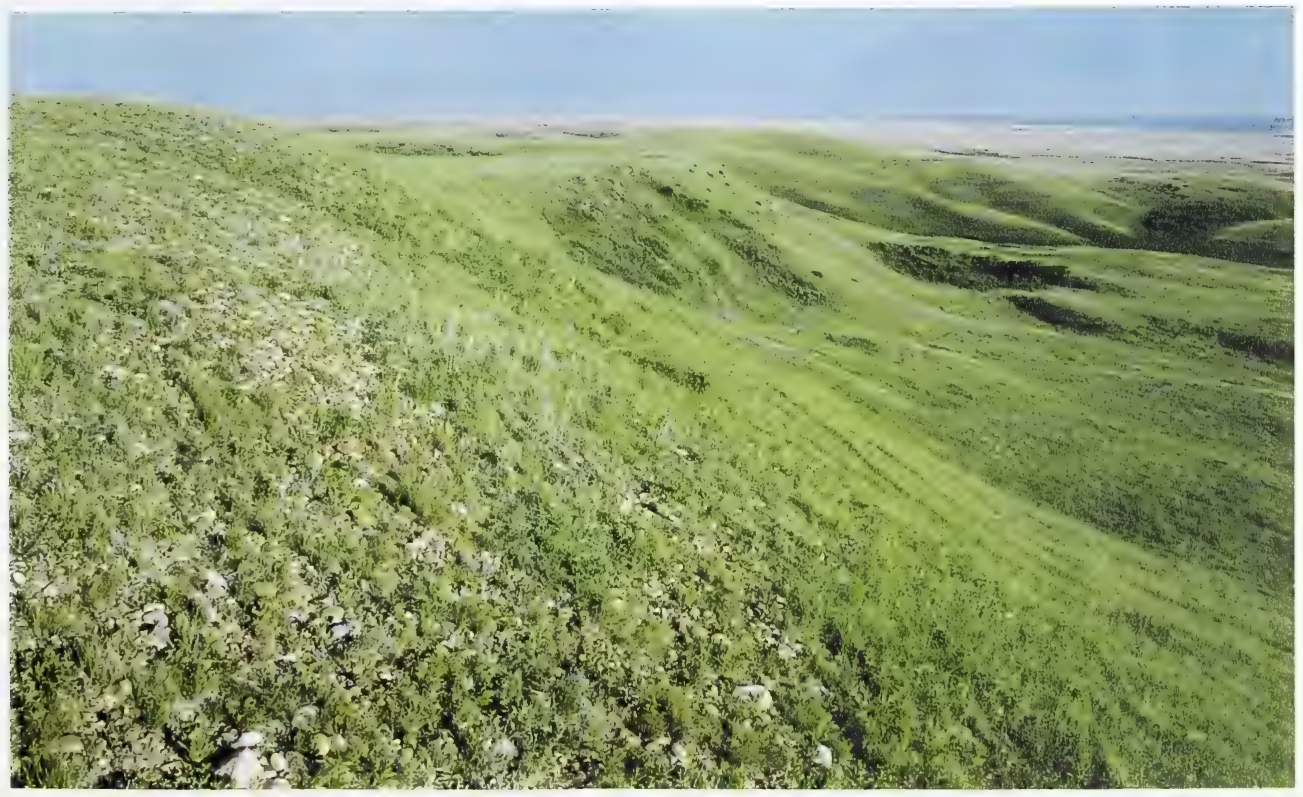

Plate 2 - Looking south-east along the edge of the escarpment. Note the tertiary gravels in the foreground and the bedrock outcroppings along the slope break in the middle ground. Slopes in the photo are about 50\%. Note also the localized patches of tall mixed-shrubs in the depressional areas at the base of the slopes. The Red Deer River valley can be seen in the upper right corner. 



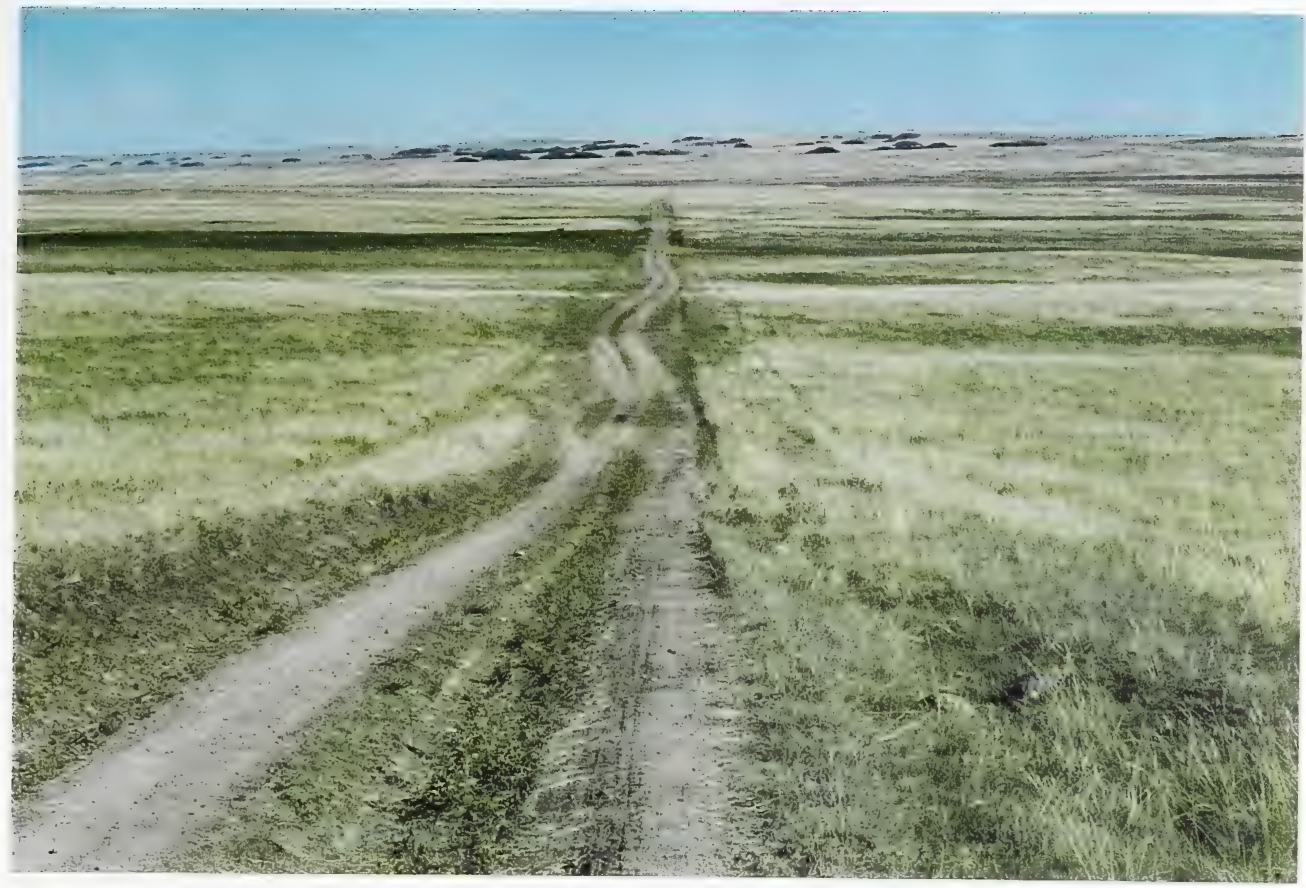

Plate 3 - Looking north along the main truck trail which runs through the Reserve. The vegetation in the foreground is Rough Fescue - Western Porcupine Grasslands, with Buckbrush - Rough Fescue shrubbery on moister sites (i.e. the dark green patches). This view takes in the slightly rolling plains of the central part of the Reserve, with the aspen copses of section 25 in the distance.

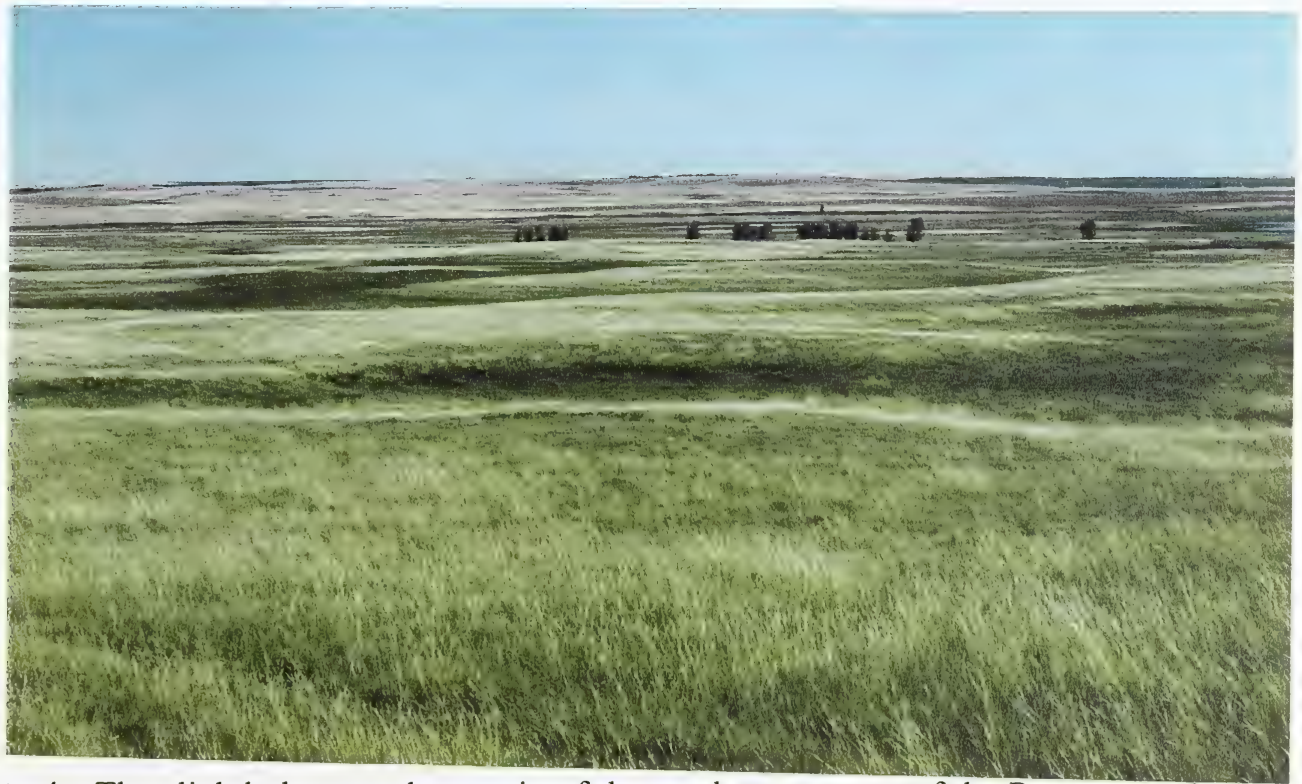

Plate 4 - The slightly hummocky terrain of the south-east corner of the Reserve, at the base of the Southern Highlands. The vegetation is Western Porcupine Grass - Rough Fescue - Forb grasslands (yellow) dissected with Mixed Grass - Forb meadows along the ephemeral drainage channels (dark green). The poplar trees in the distance mark the high water shoreline of Little Fish Lake, with the dry lake bed beyond. 



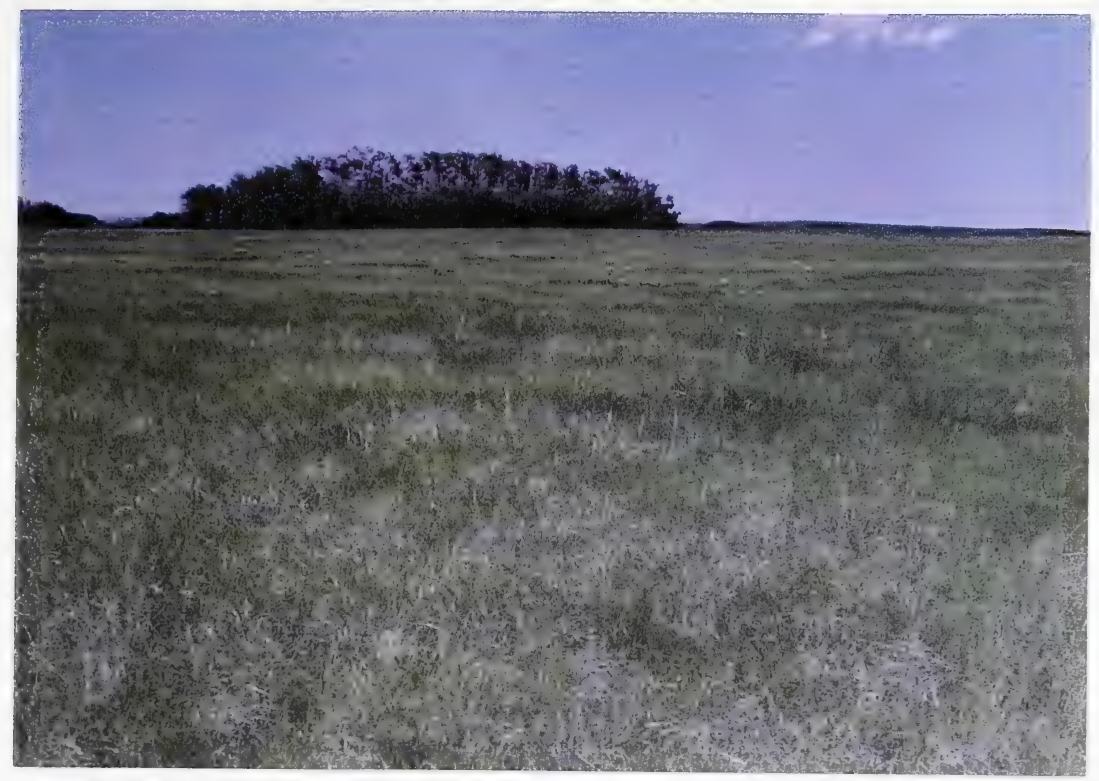

Plate 5 - Rough Fescue grassland in an area which is hayed but not grazed (section 25). The grass is a thick, lush blanket of vegetation, broken only by aspen copses. Floristic diversity is generally low as the fescue covers about $80 \%$ of the ground surface. The copse in the distance has the typical shape of an expanding aspen clone; older dead trees in the centre, new growth along the outside.

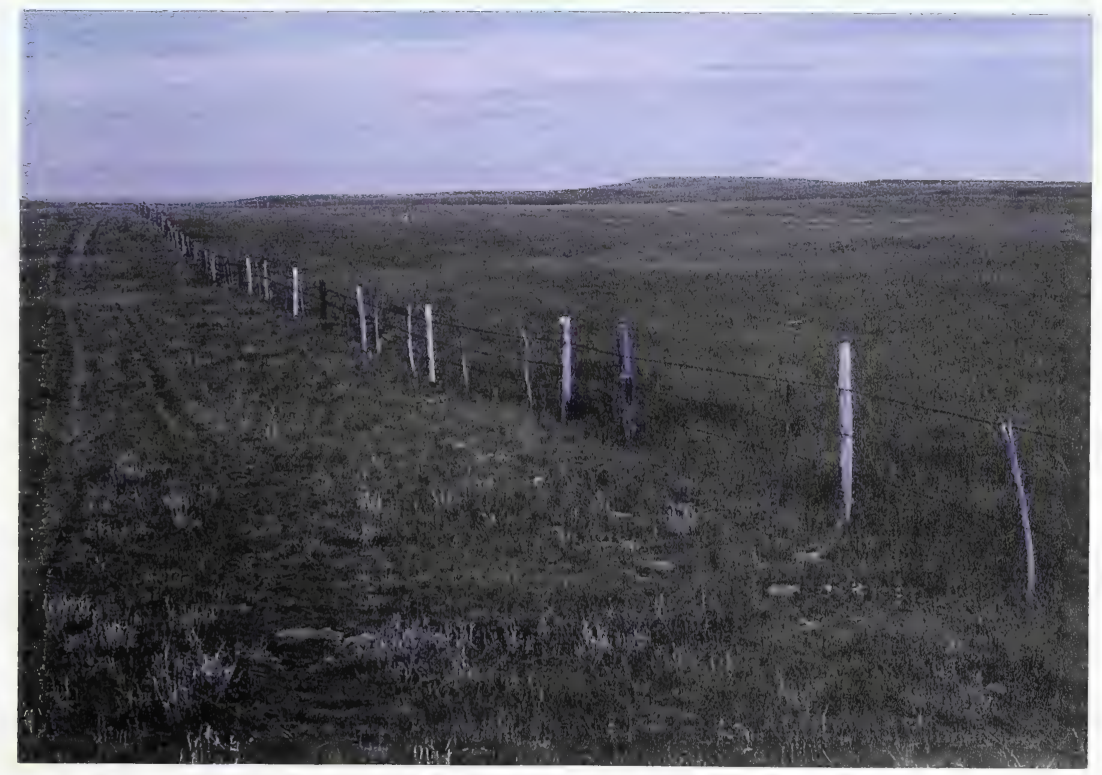

Plate 6 - The effects of grazing are plainly visible here. Ungrazed Rough Fescue has left a thick carpet of unbroken grassland on the far side of the fence; heavy grazing of the fescue grass has resulted in a Needle-and Thread - Sage - Selaginella grassland on the near side of the fence. This area is on top of the Southern Highlands. 



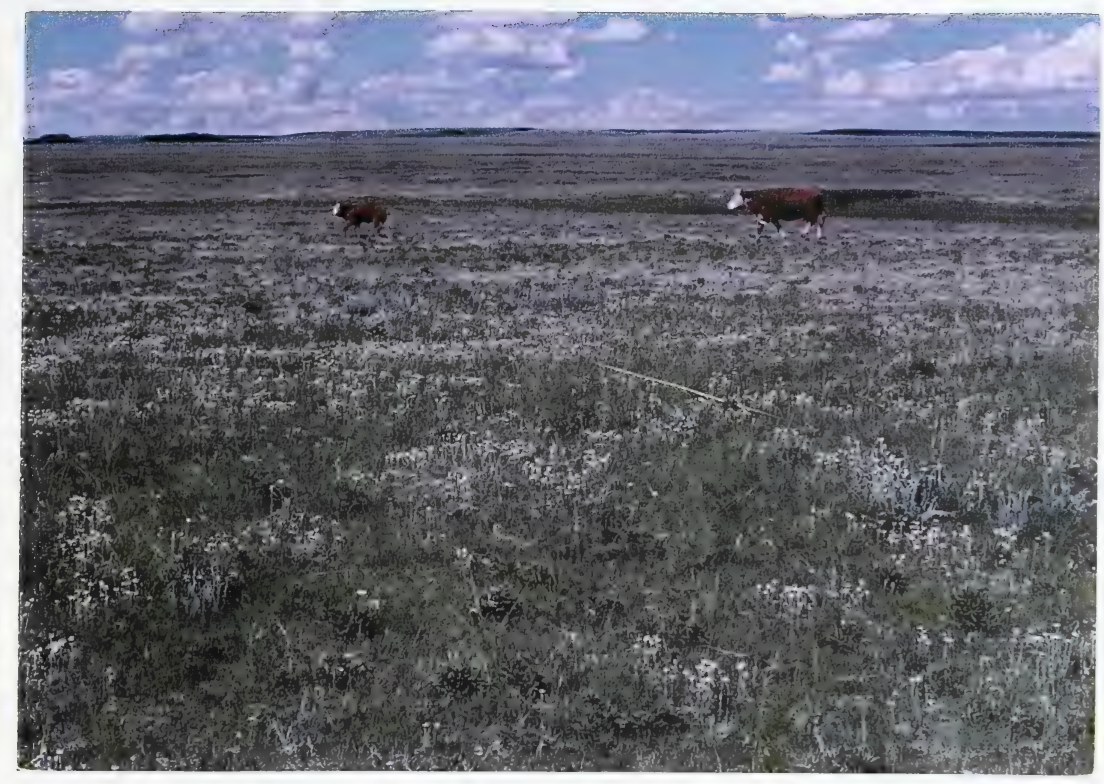

Plate 7 - Heavy grazing has resulted in this June Grass - Sedge - Sage - Selaginella community. Note the high cover of Low Everlasting and Pasture Sagewort. This area has a mixture of Chernozemic and Solonetzic soils.

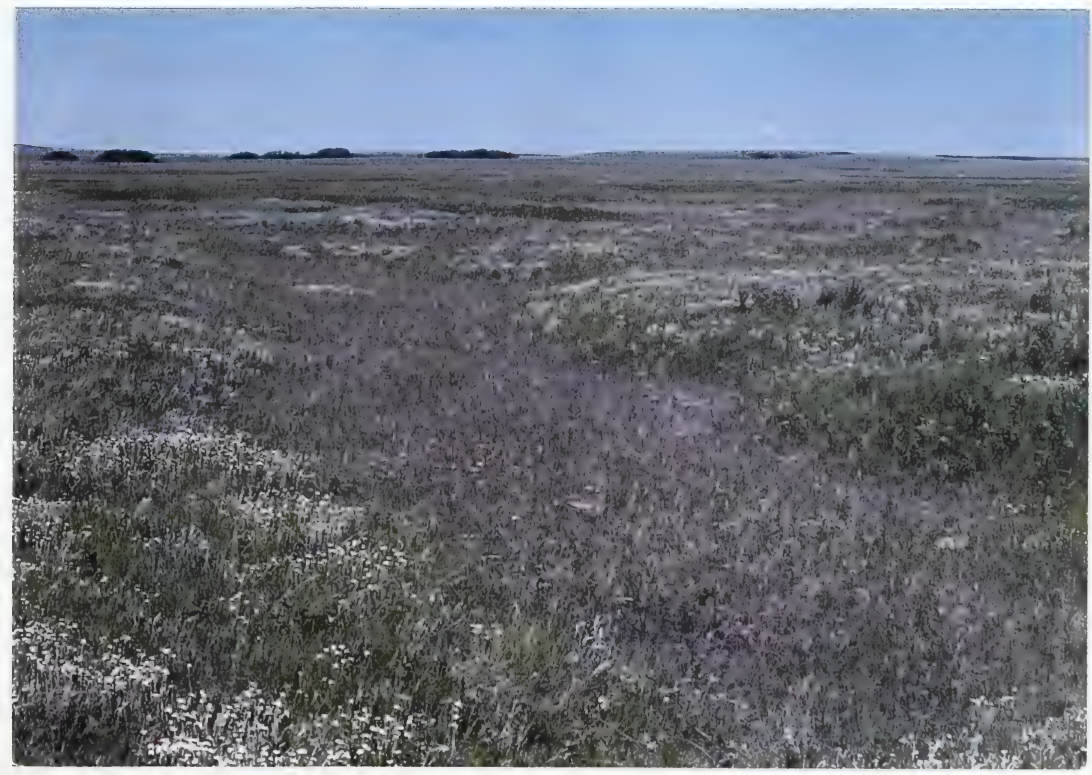

Plate 8 - The Gumweed - Bluegrass - Foxtail Barley community. This site is characterized by Solonetzic soils, heavy grazing and the presence of invader plant species. 



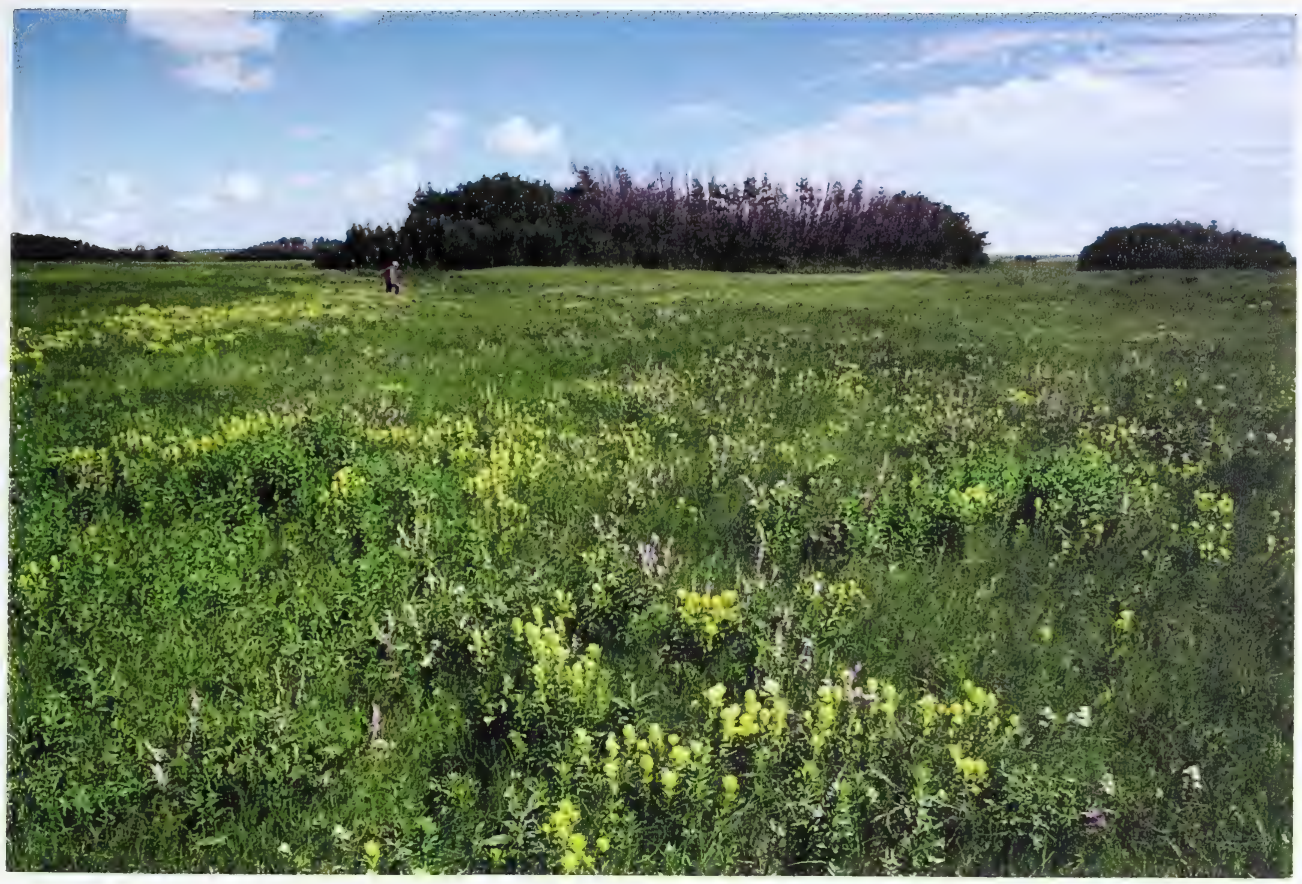

Plate 9 - A Mixed Grass - Forb meadow in an ephemeral drainage channel. These features, in which are found most of the aspen copses (i.e. in section 25) are characterized by spectacular flower blooms in wet years. Dense Rough Fescue grasslands border these drainage channels. Several aspen copses are seen in the background.

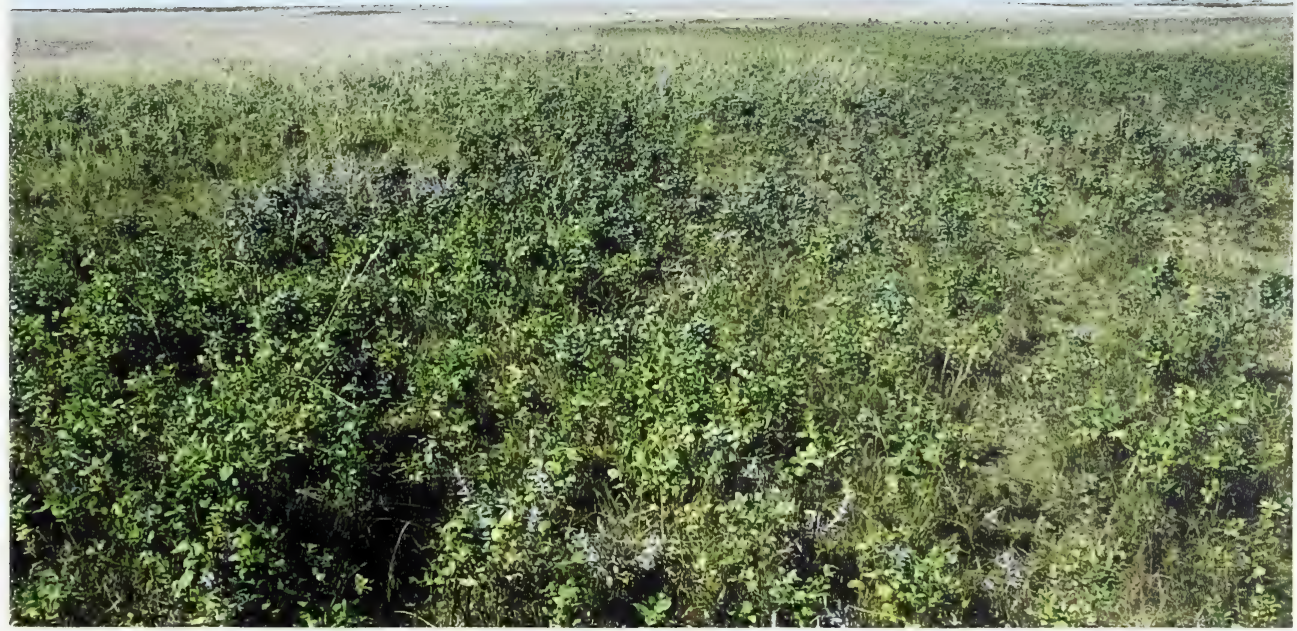

Plate 10 - A Buckbrush - Rough fescue shrub community. In upland areas they are generally restricted to shallow ephemeral drainage chanels, surrounded by dry grasslands. The buckbrush can be quite dense but are usually damaged by heavy grazing. 



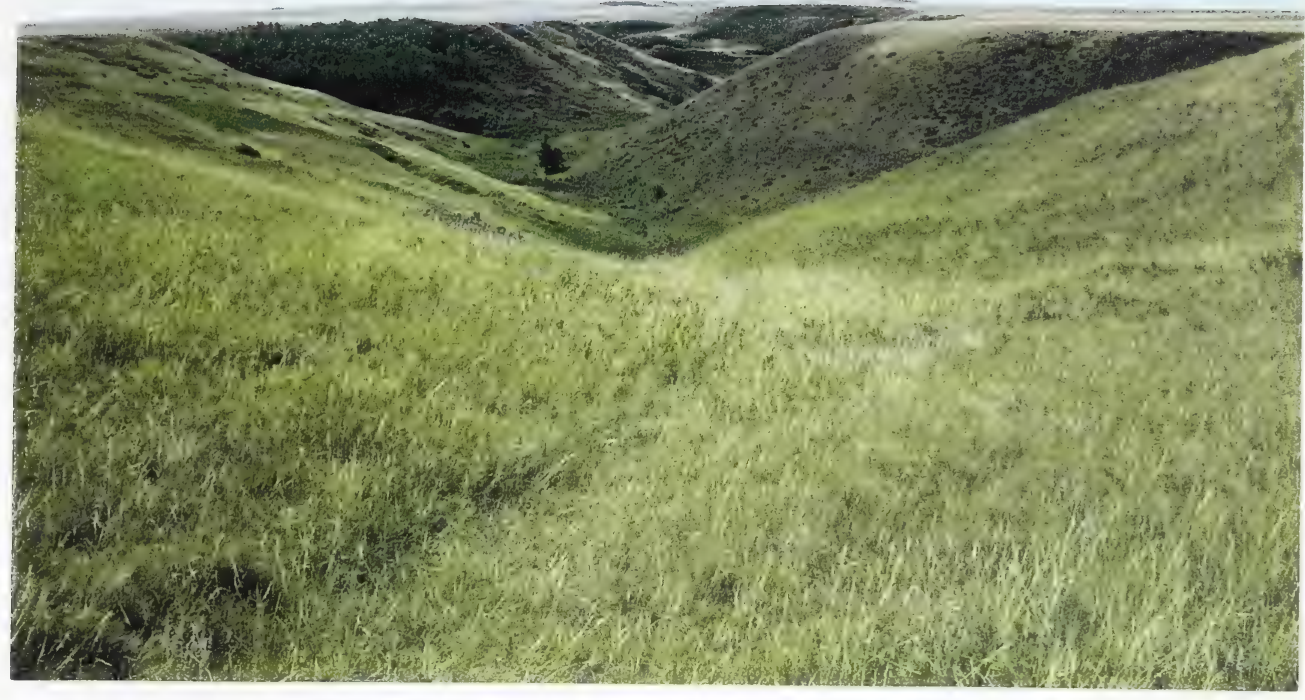

Plate 11 - The large coulee, near the western edge of the reserve, with Thumb Hill in the distance. The coulee at this point is 180 meters ( 590 feet) across and 24 meters ( 79 feet) deep. Tipi rings were found at this spot. Rough Fescue grassland is in the foreground. The dark green patch of vegetation along the north-facing coulee wall (in the left of the photo) is an Aspen - Buckbrush - Forb - Wheat Grass woodland.

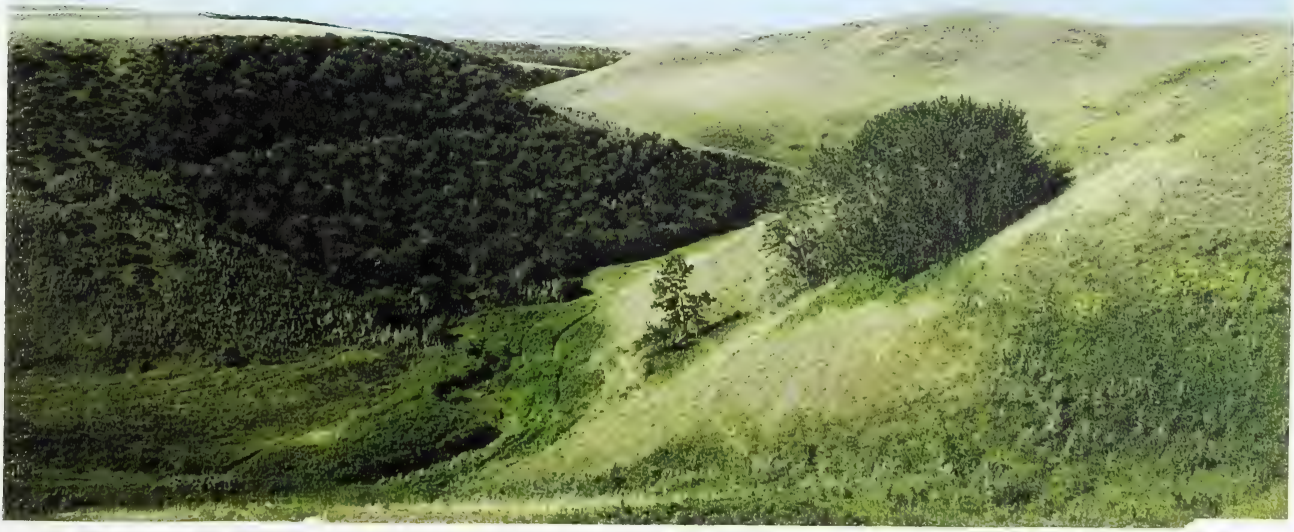

Plate 12 - The range of coulee vegetation. The south-facing slopes (right side of photo) are dominated by the Rough Fescue - June Grass - Juniper - Forb community, with occasional patches of Poplar Buckbrush - Wheat Grass woodlands and Buckbrush - Rough fescue shrubbery. The north-facing slopes have Salix/Saskatoon - Rough fescue/Bluegrass shrubs, bordered by Buffaloberry - Rough fescue shrub communities. The coulee bottom has a Rough hair Grass - Sedge meadow. 



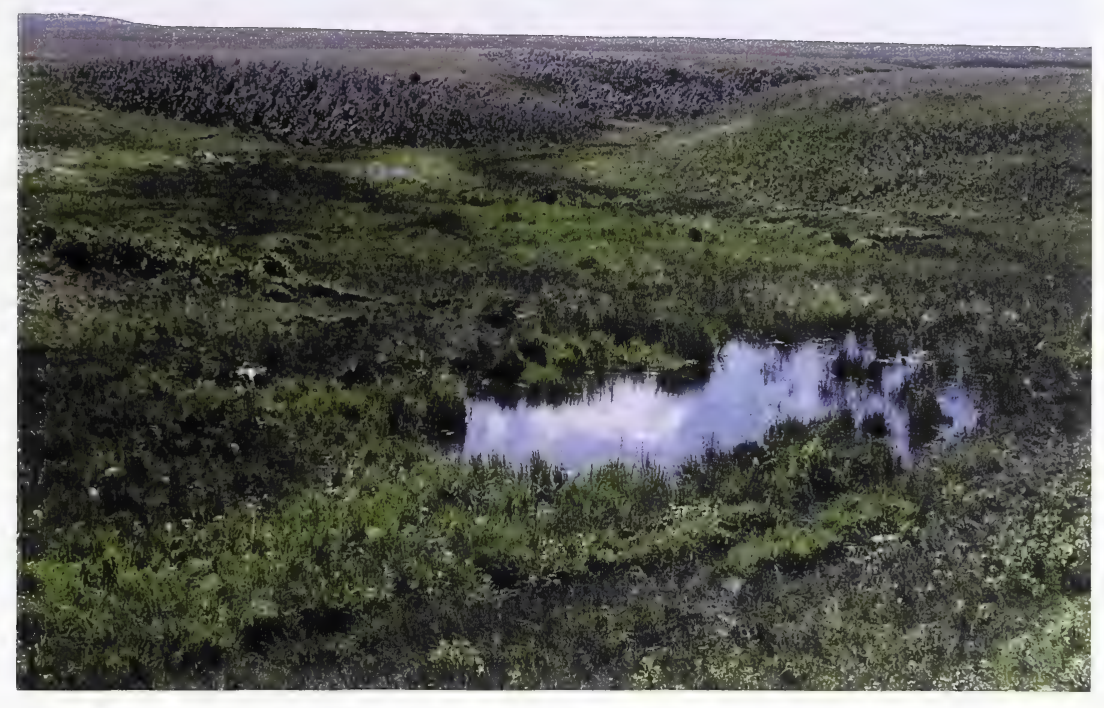

Plate 13 - The Sedge - Wire Rush wetland. There are only a few of these wetlands in the coulees and they probably contain standing water only during wet years. Note the Silverberry - Rough Fescue Hooker's Oat Grass community along the coulee slopes.

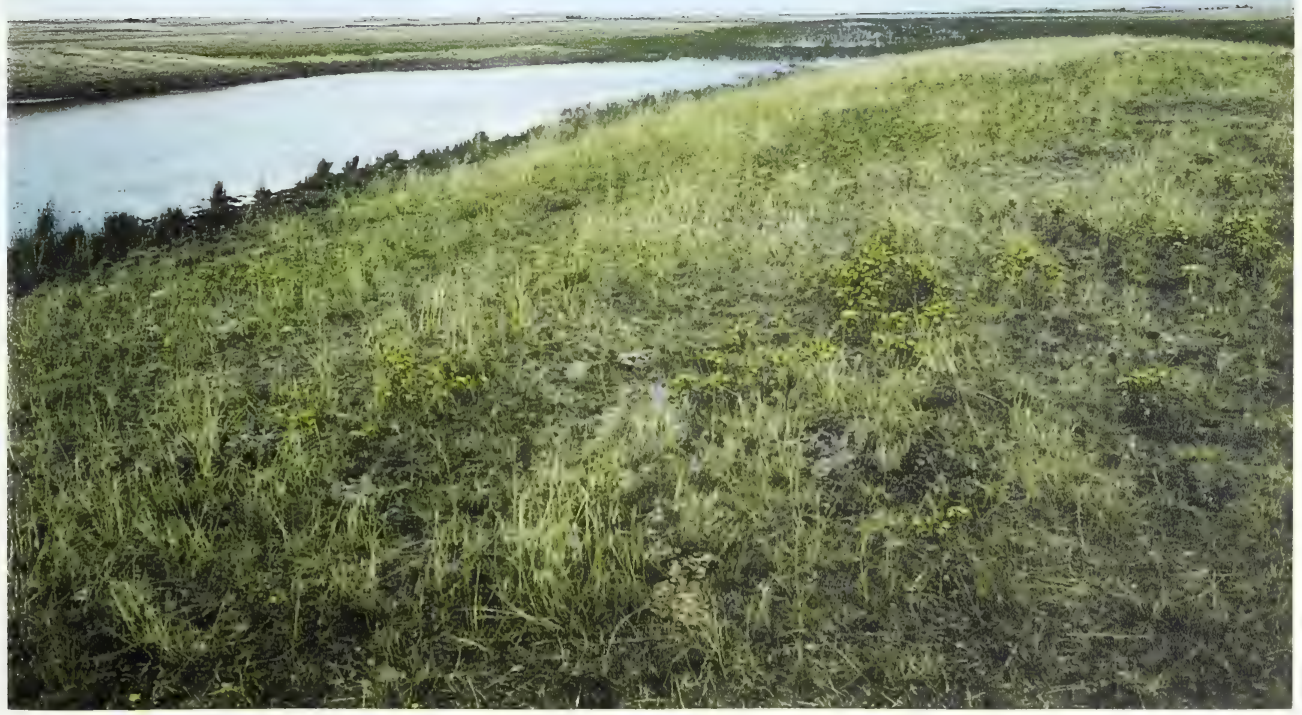

Plate 14 - The reservoir/marsh. The open part is actually a dugout put into the marsh and the foreground is the spoil pile, covered with invasive plant species. The natural part of the marsh is in the distance, almost obscured by bulrushes. This wetland receives very heavy use by both natural wildlife and cattle. 



\section{Appendix X Maps and Air Photos}

The following is a list of all maps and air photos used in all phases of this study.

\section{Maps}

NTS 1:50,000 topographic map - $82 \mathrm{P} / 8$

Digitized maps at 1:10,000 and 1:20,00

\section{Air Photos}

Project name: Little Fish Lake

Job No.:

96-113

Roll No.: AS 4697

Date Flown: June 8, 1996

Scale: $1: 10,000$

Film: Black and white (A50)

Photos: Line 1, no.'s 1-9

Line 2, no.'s 10-18

Line 3, no.'s 19-29

Line 4, no.'s 30-39

Line 5, no.'s 40-46

Project name: Hand Hills Ecological Reserve Job No.: 90-168

Roll No.: AS 3995

Date Flown: July 30, 1990

Scale: 1:20,000

Film: Color infrared (2443)

Photos: Line 1, no.'s 124-127

Line 2, no's 130-134

Project name: Little Fish lake Job No.:

96-114

Roll No.:

AS 4697

Date Flown: June 13, 1996

Scale: 1:40,000

Film:

Black and white (A50)

Photos:

Line 1, no.'s 258-271 


\title{
HAND HILLS ECOLOGICAL RESERVE
}

\section{SIGNIFICANT FEATURES}

\author{
SCALE 1:10,000
}

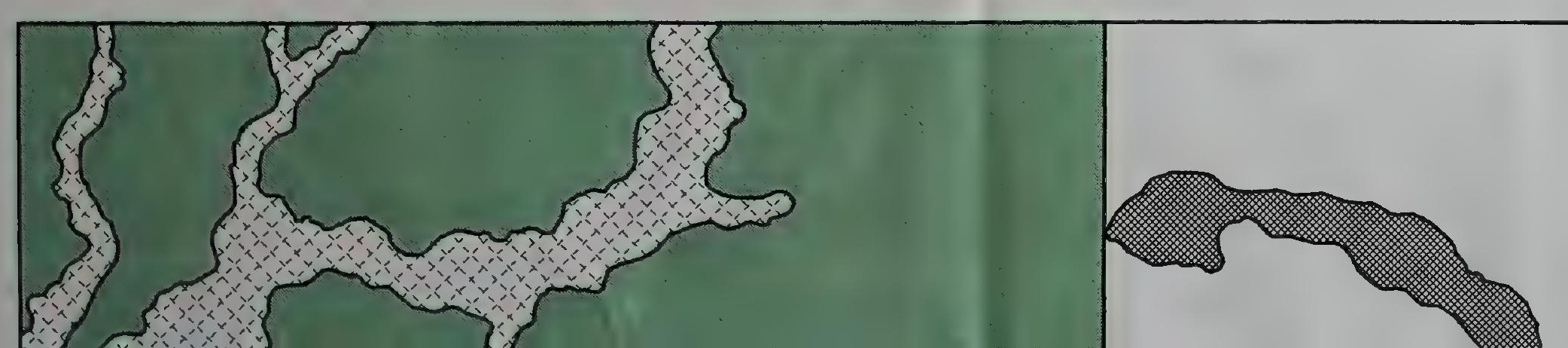


RESERVE

TURES 


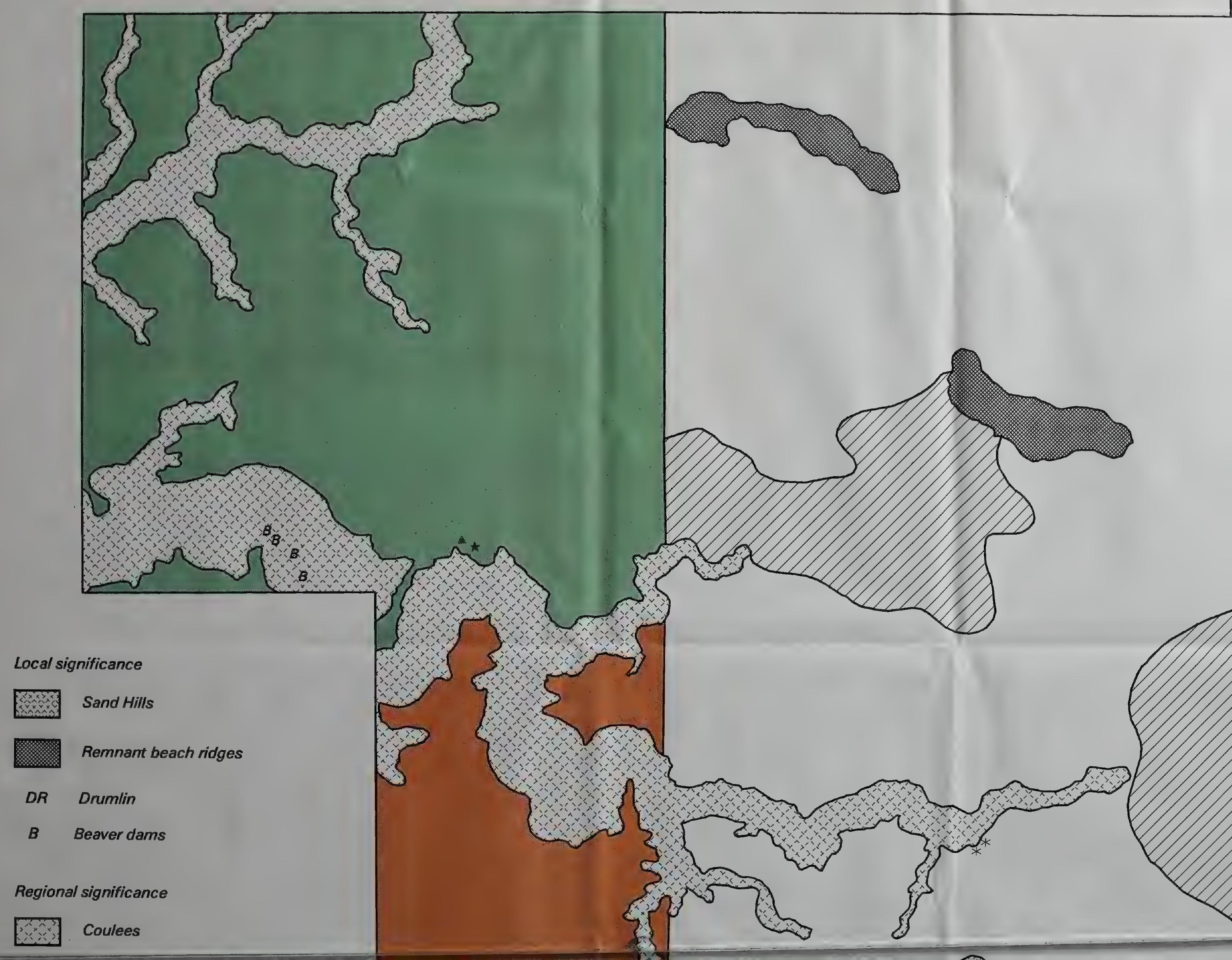



Regional significance

Coulees

Concentric geomorphic feature

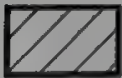

\section{Richardson's Ground Squirrel} (prime habitat)

\section{Archaeological features}

* $\quad$ tipi rings

A stone piles

* stone patterns

Provincial significance

\section{$\therefore$ Escarpment} (other than Fescue grass/and)

$\boxplus \quad$ Sharp-tailed Grouse dancing grounds

\section{National significance}

A Piping Plover nesting habitat

International significance

Northern Fescue grassland

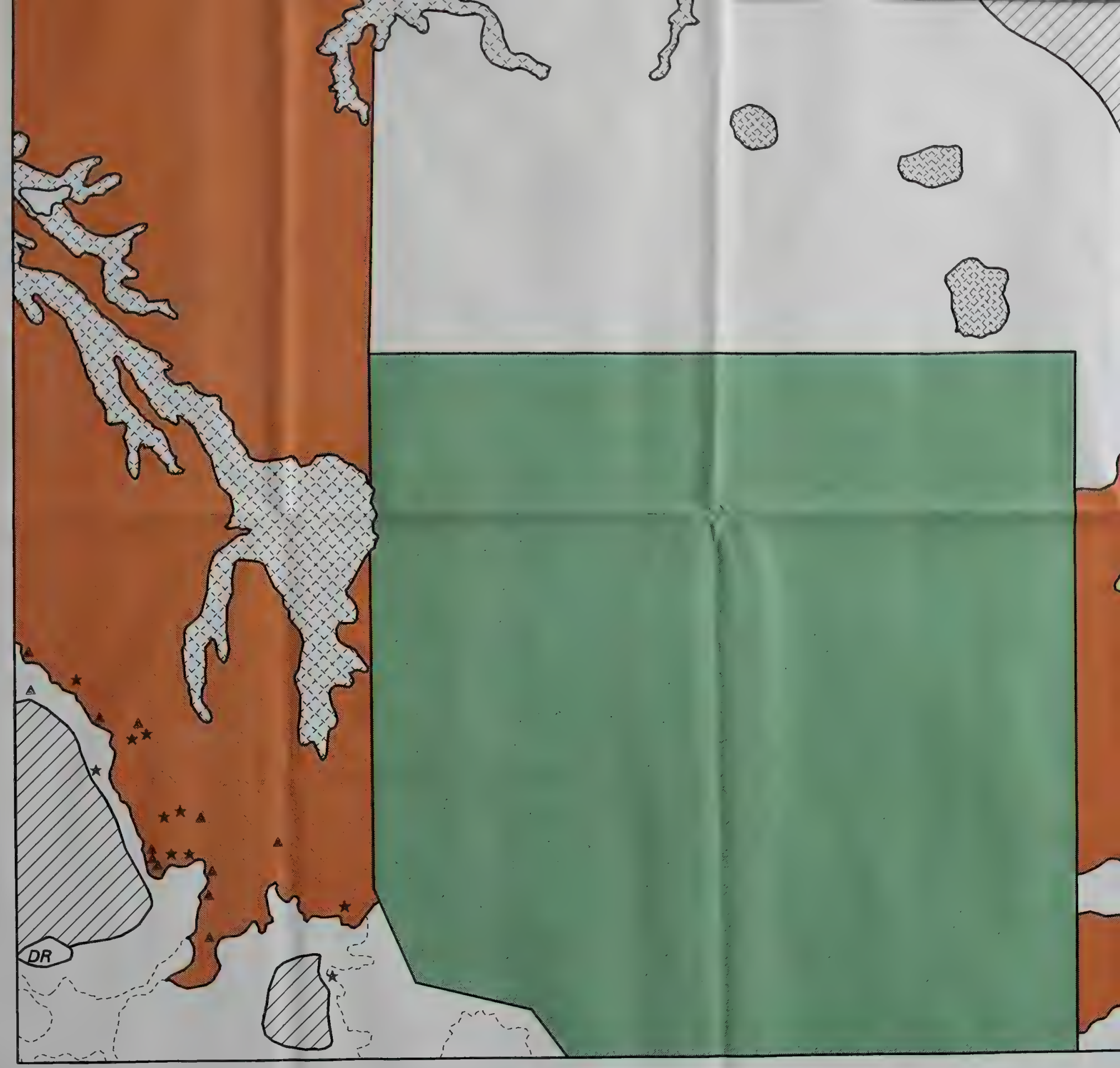




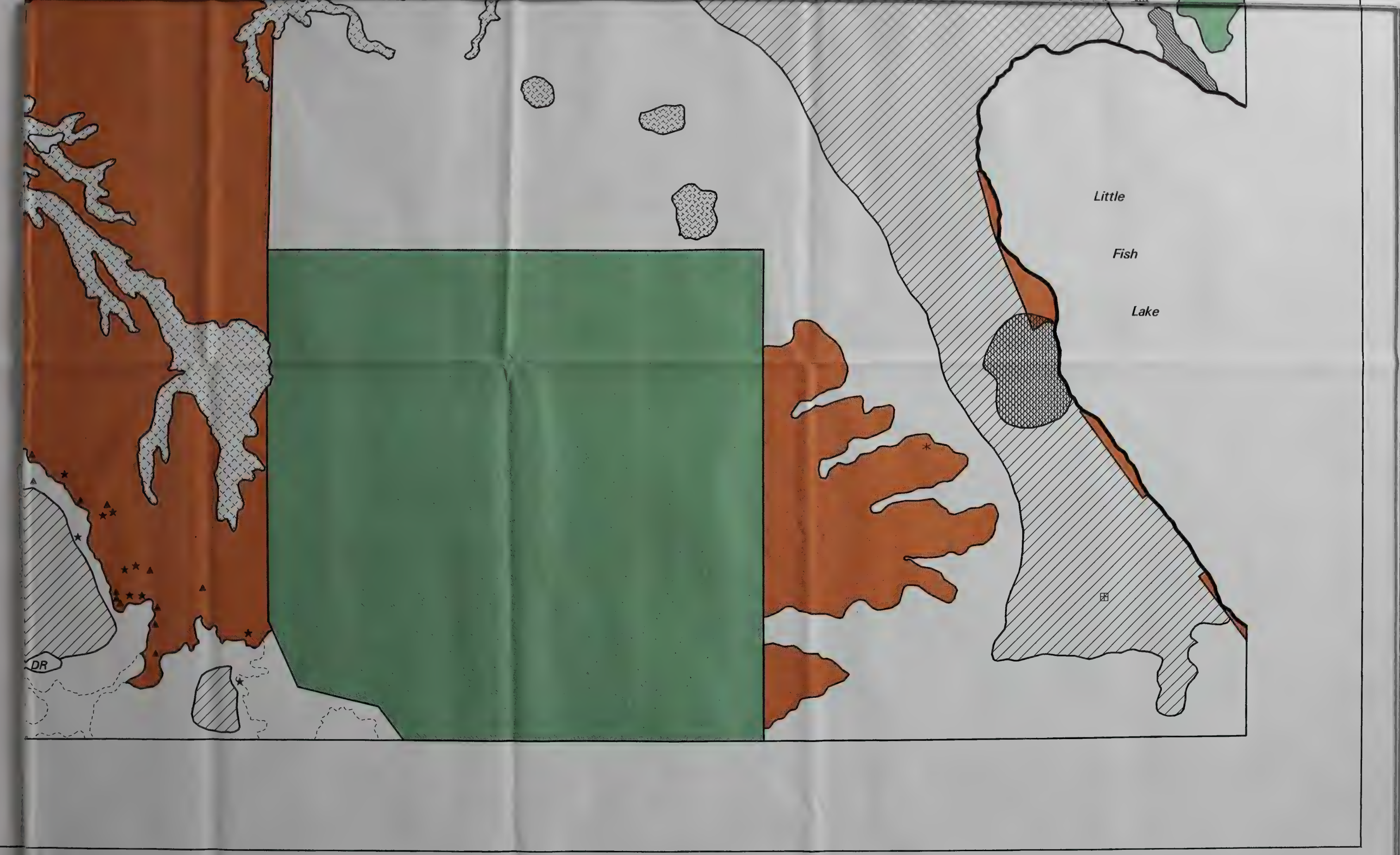




\section{HAND HILLS ECOLOGICAL RESERVE}

\section{LAND USE AND DISTURBANCE FEATURES}

SCALE $1: 10 \quad 000$

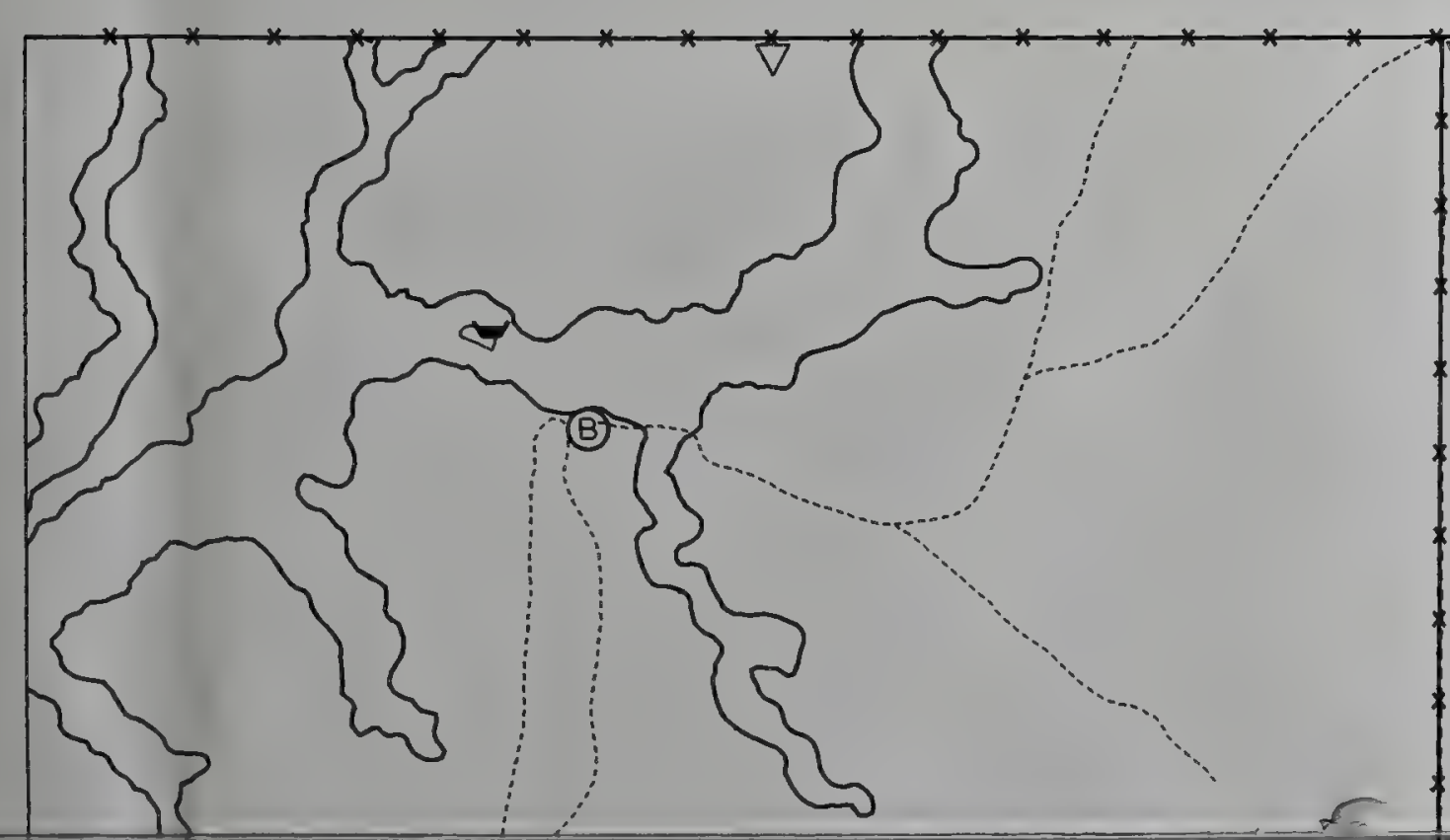




\section{RESERVE}

E FEATURES

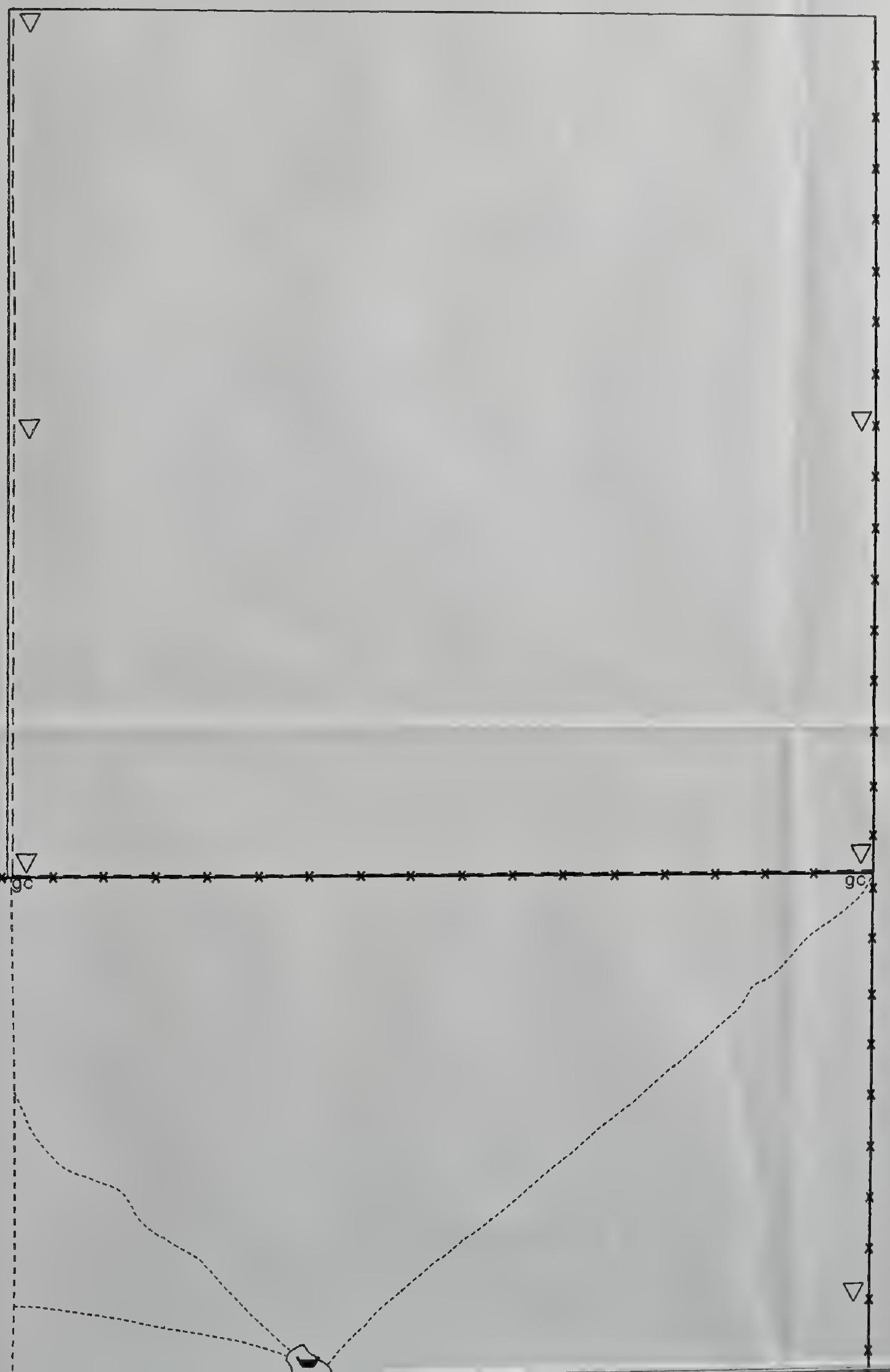




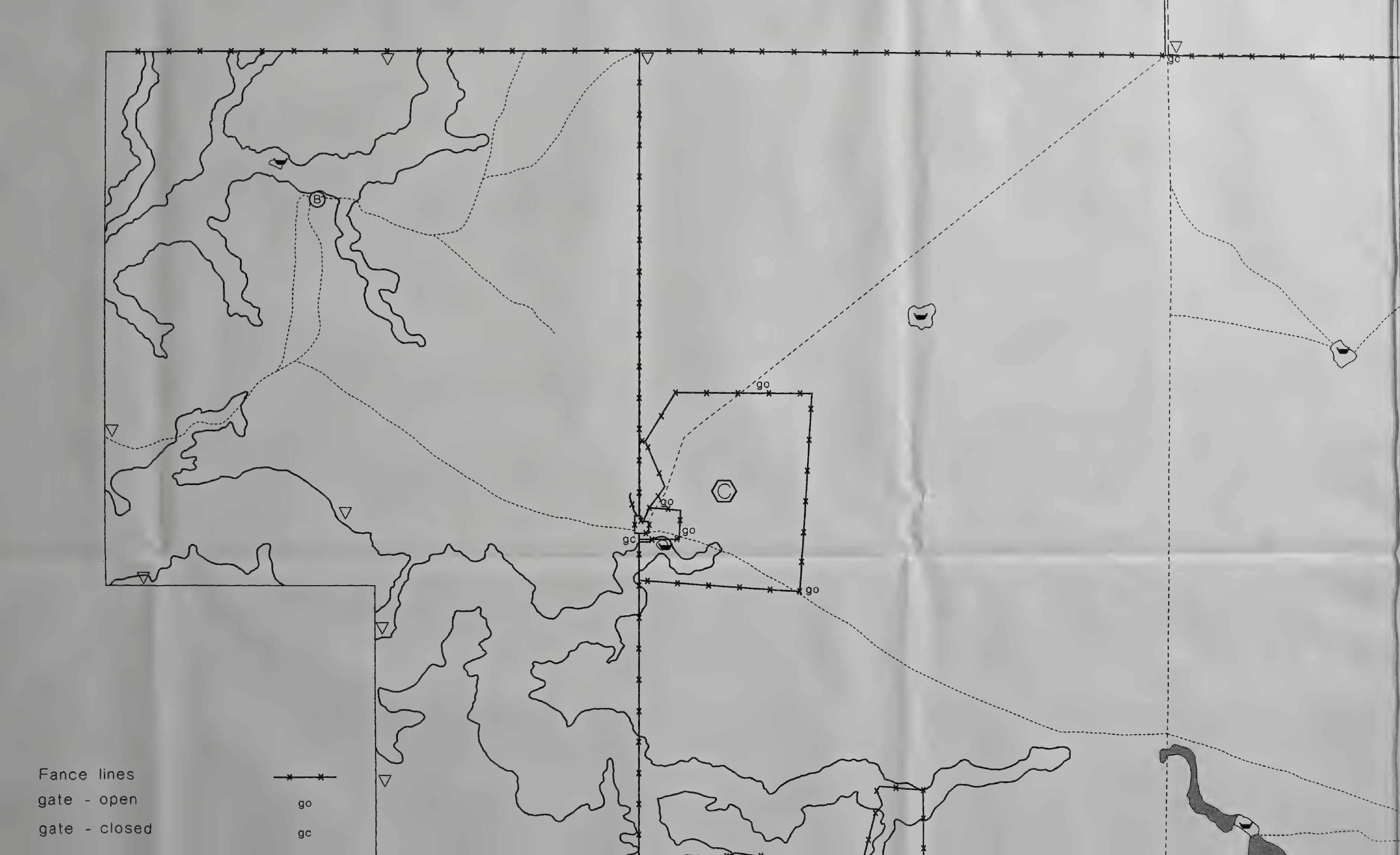





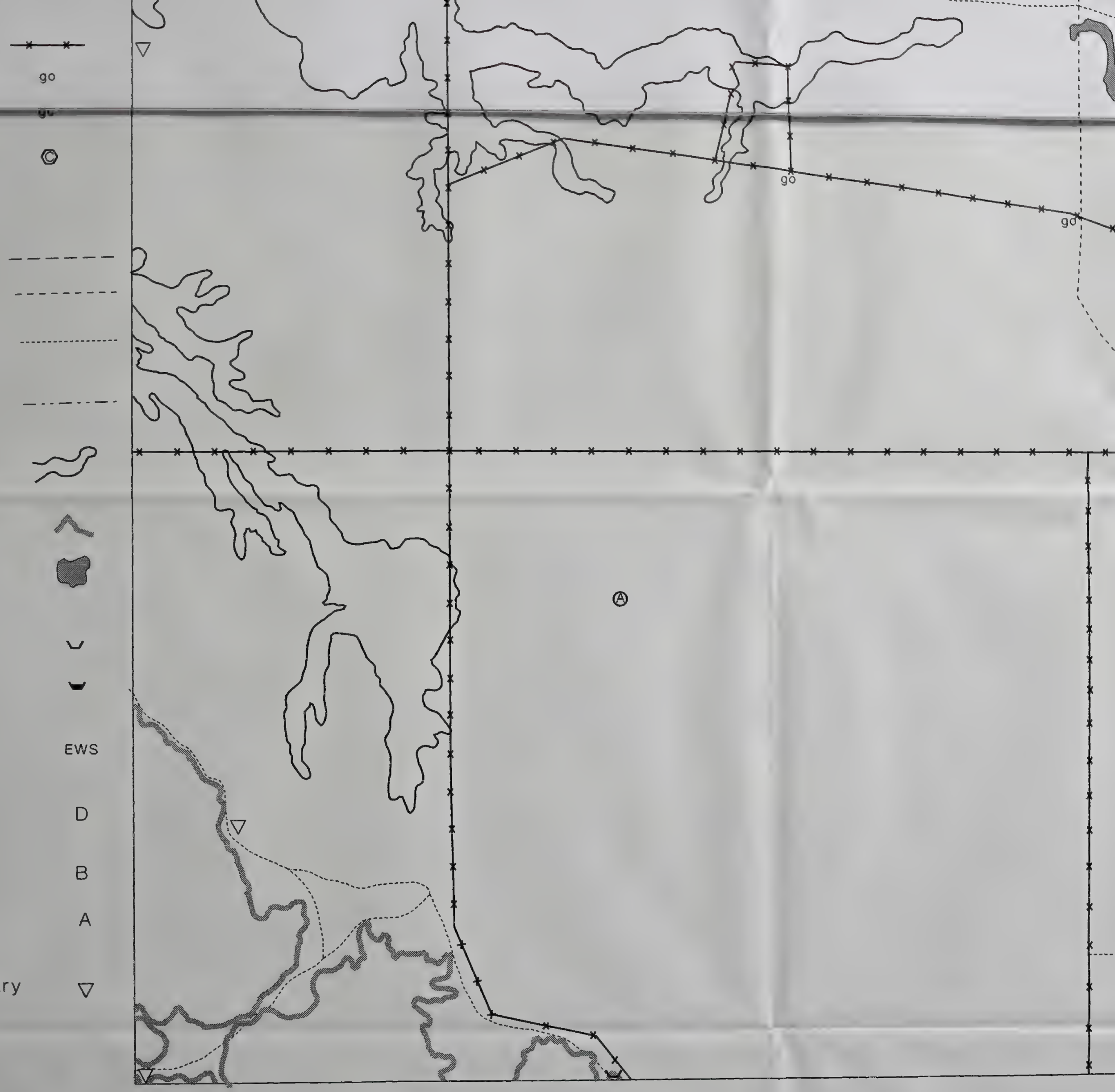




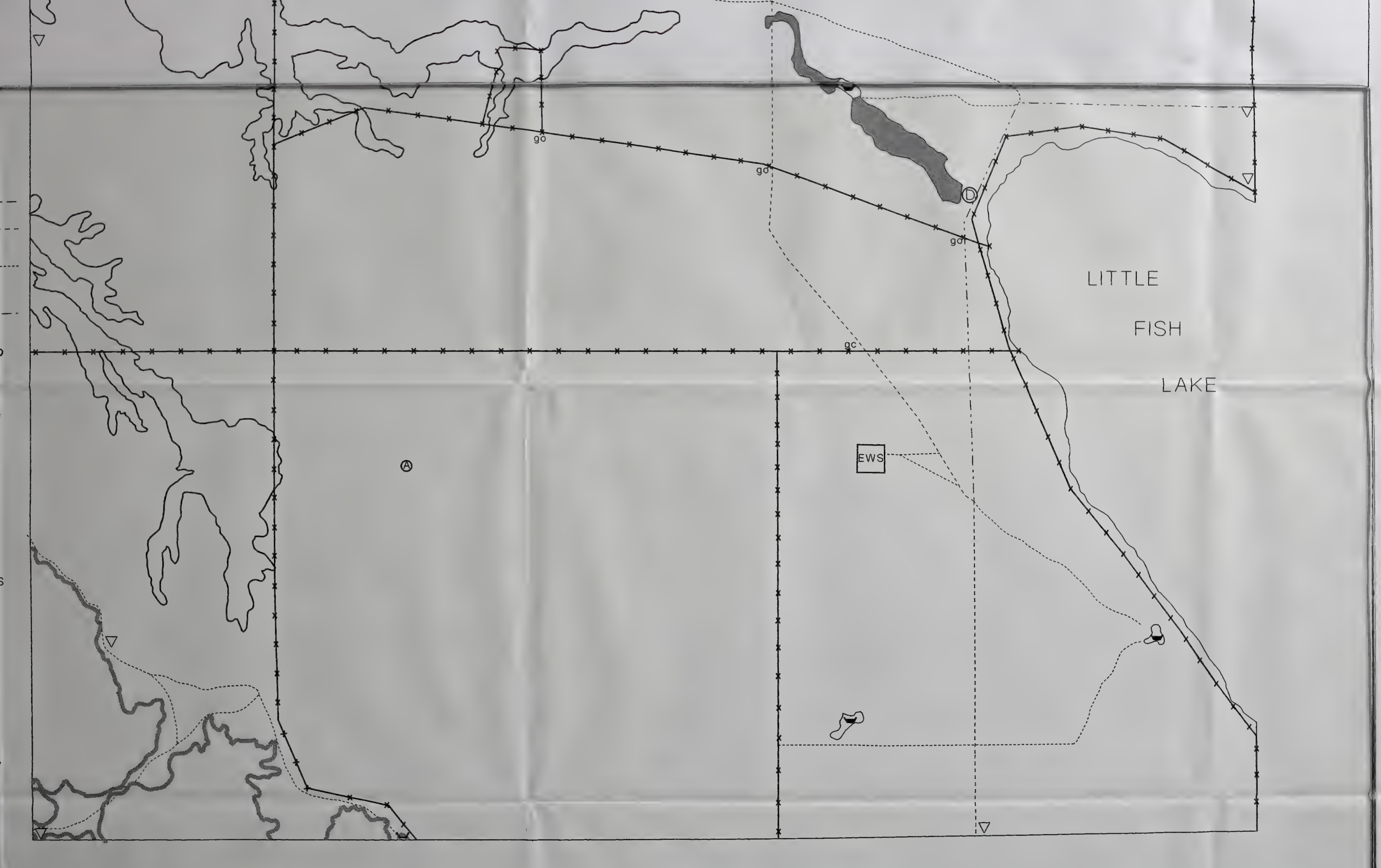




\section{HAND HILLS ECOLOGICAL RESERVE}

\section{RANGE CONDITION}

SCALE 1:10,000

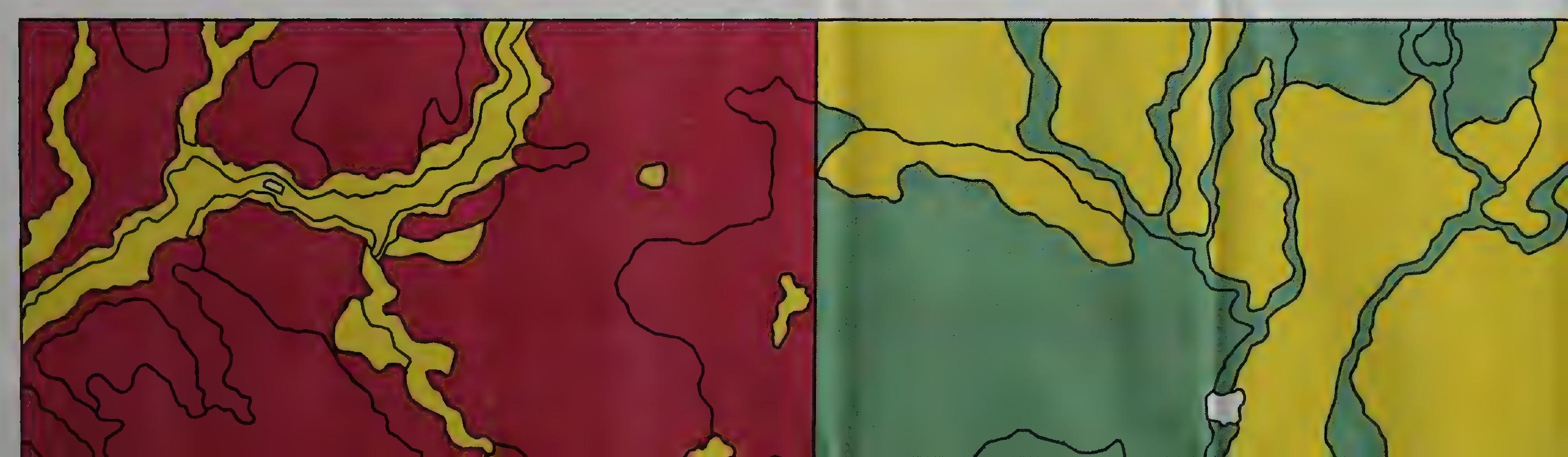




\section{LOGICAL RESERVE}

CONDITION

\section{$1: 10,000$}

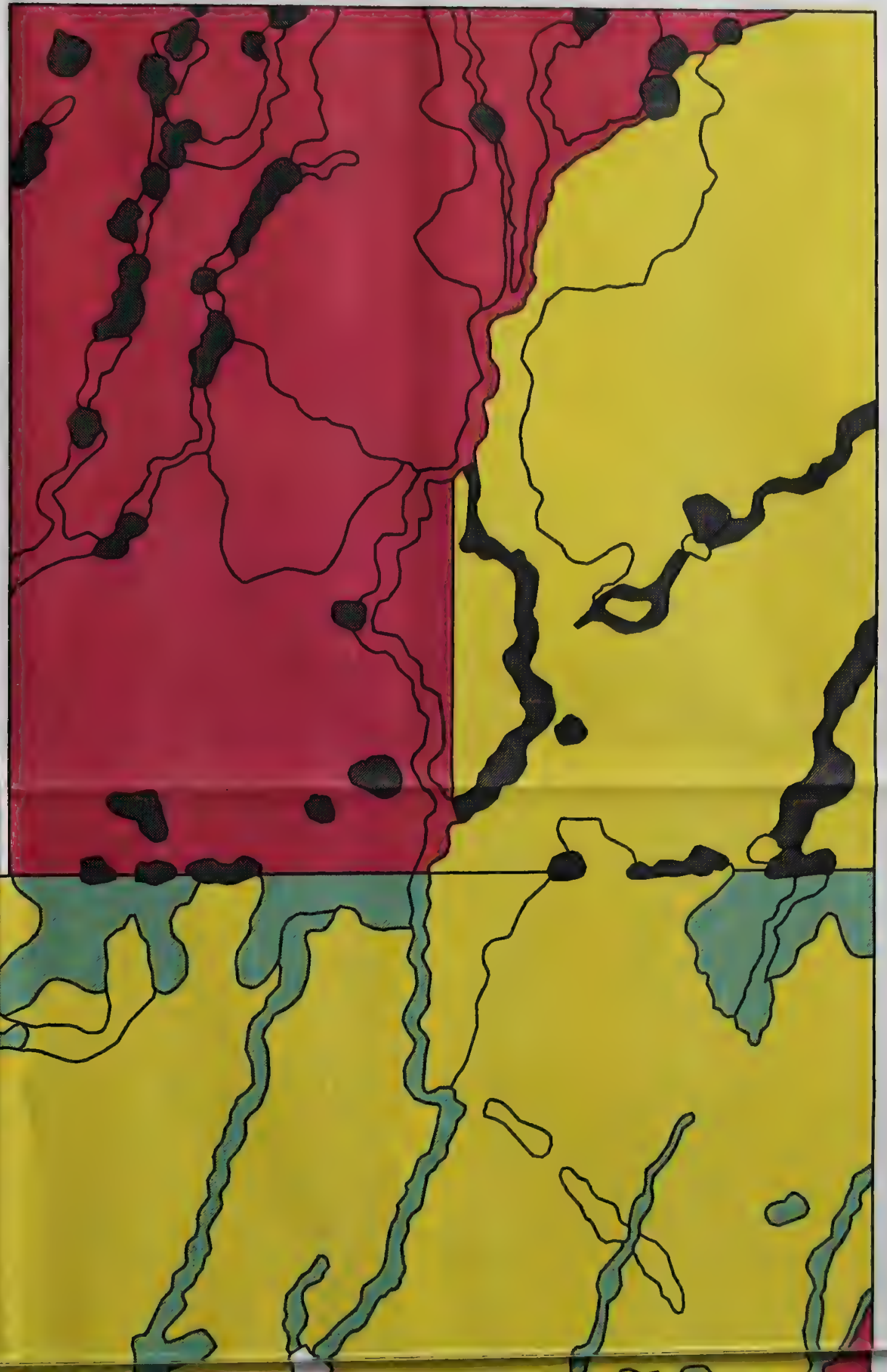




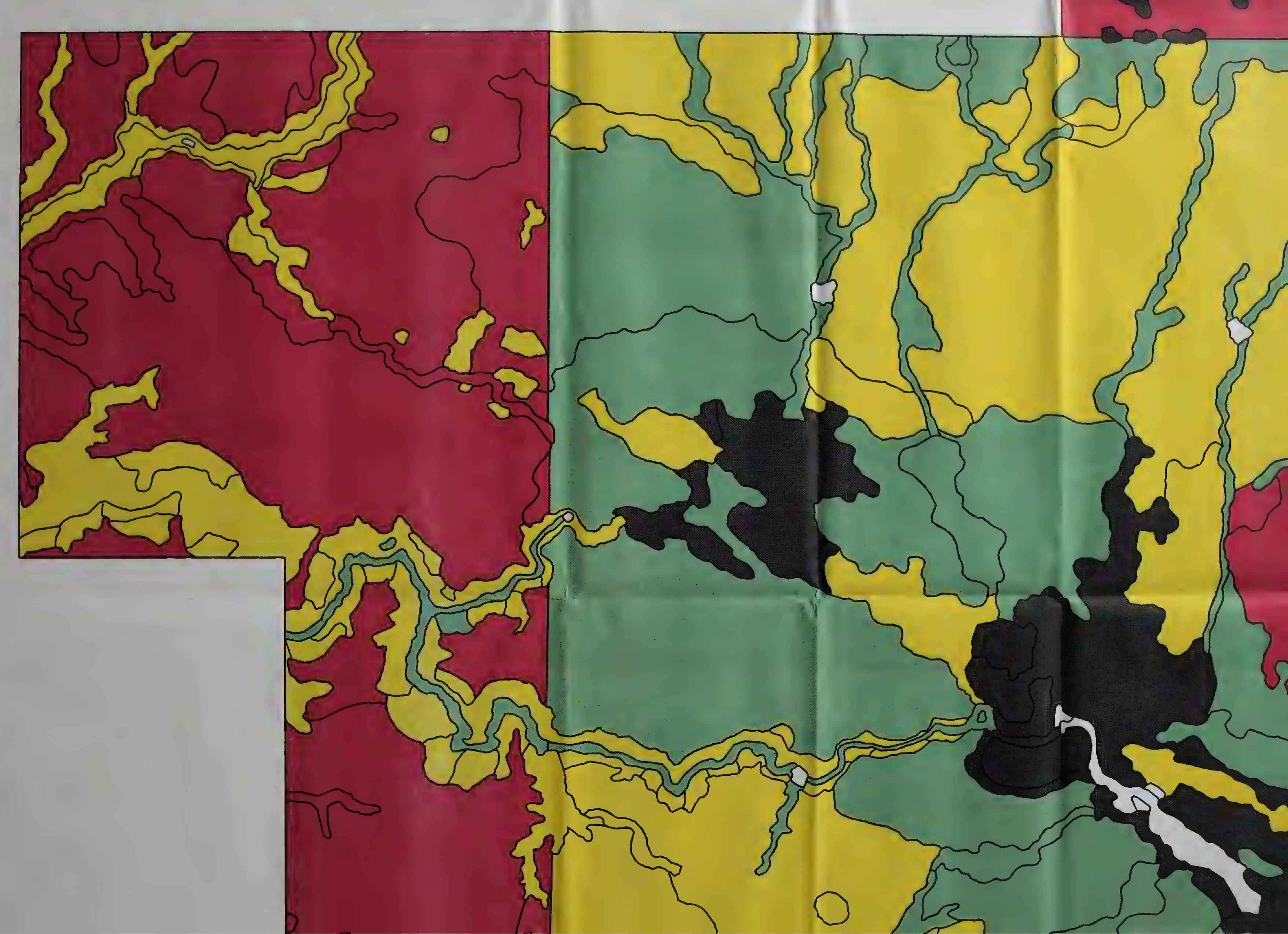




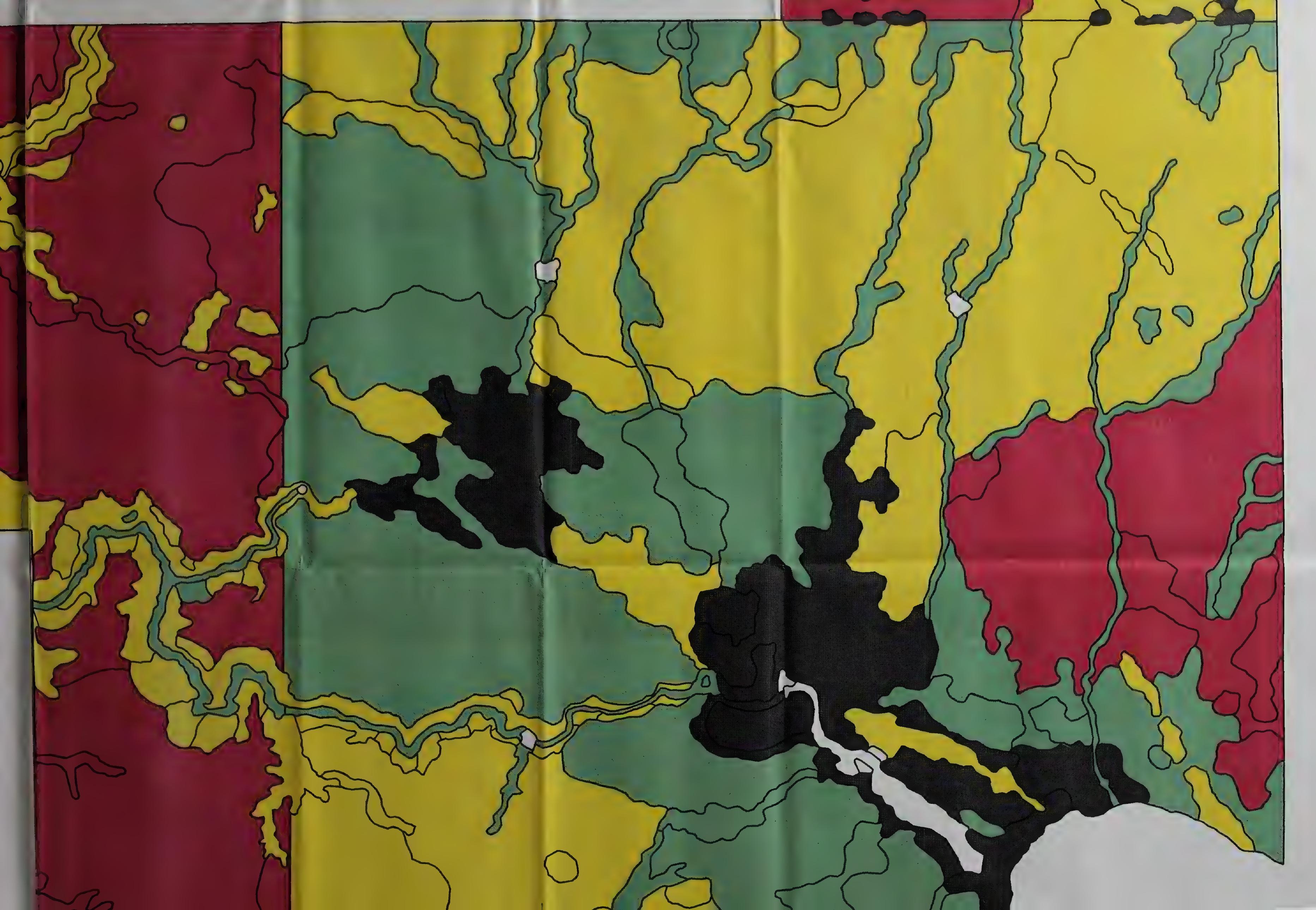


Range classes:

$\square$ Excellent

$\square$ Good

$\square$ Fair

Poor

$\square$ Unclassified
(3)

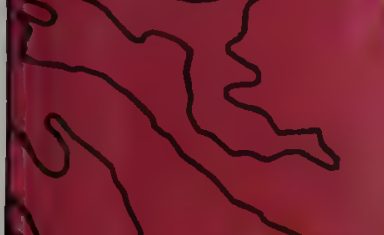

1
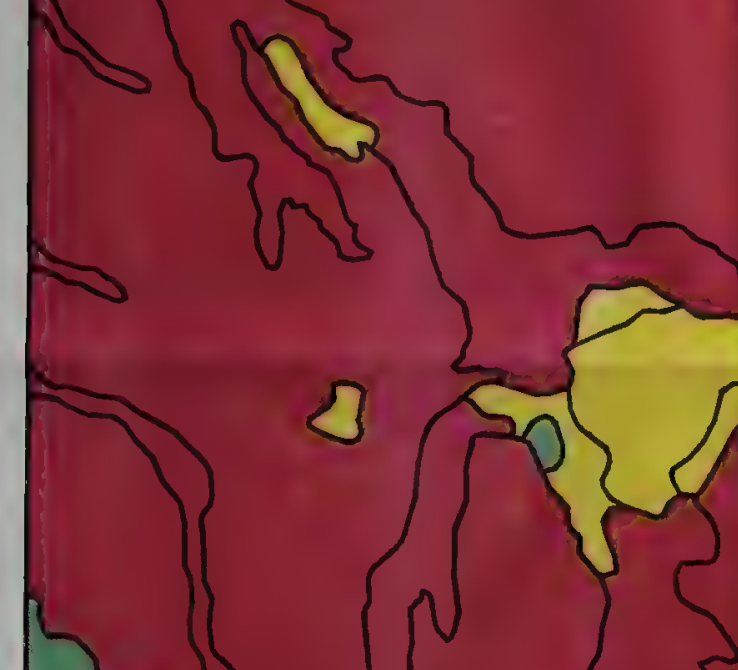

$\circlearrowright$
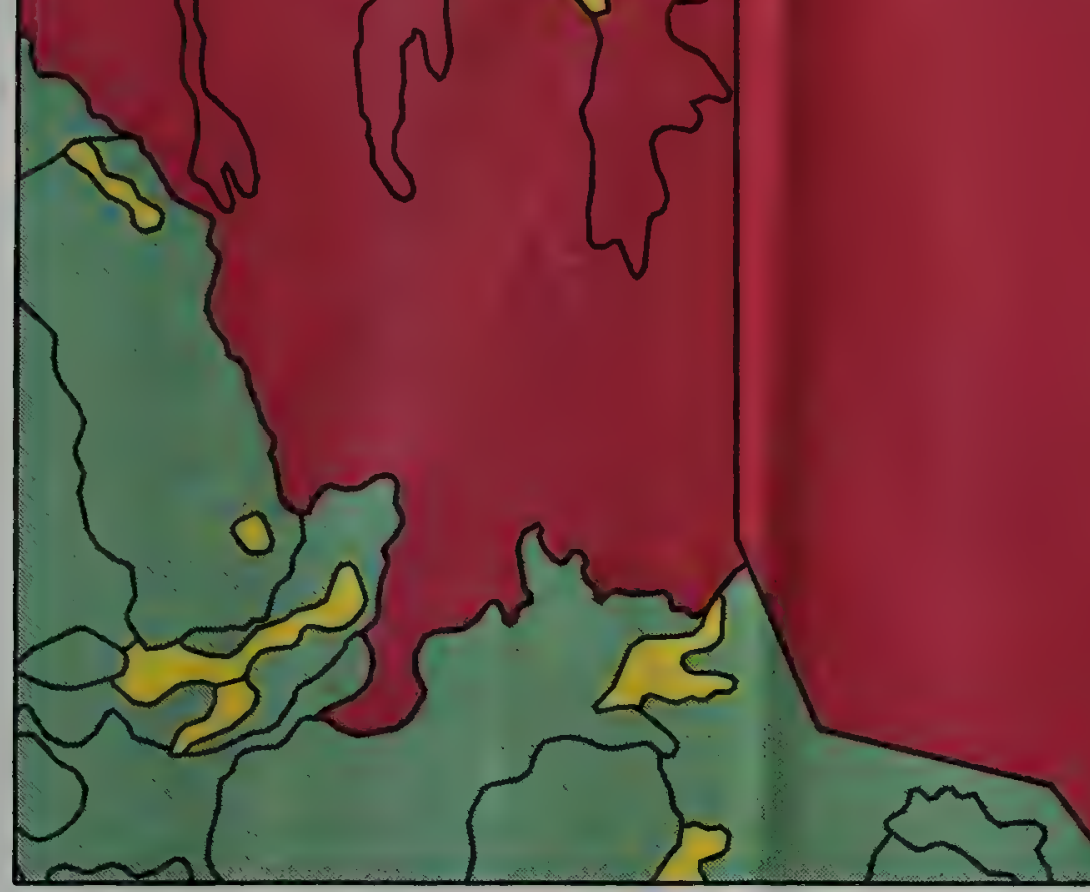
HAND HILLS ECOLOGICAL RESERVE STUDY AREA

SCALE 1:10 000

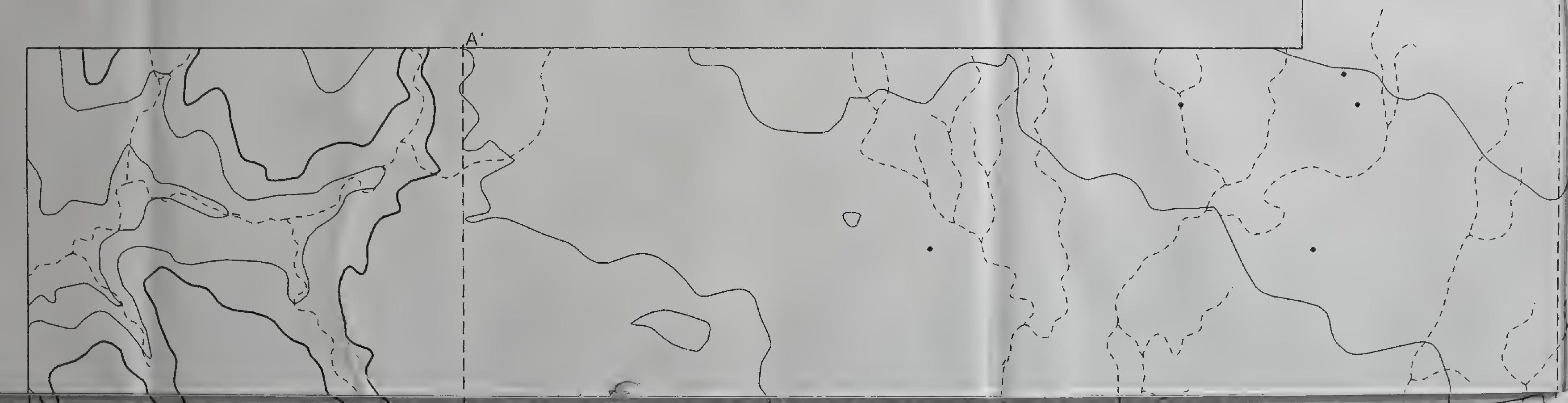


ECOLOGICAL RESERVE TUDY AREA

CALE 1:10 000

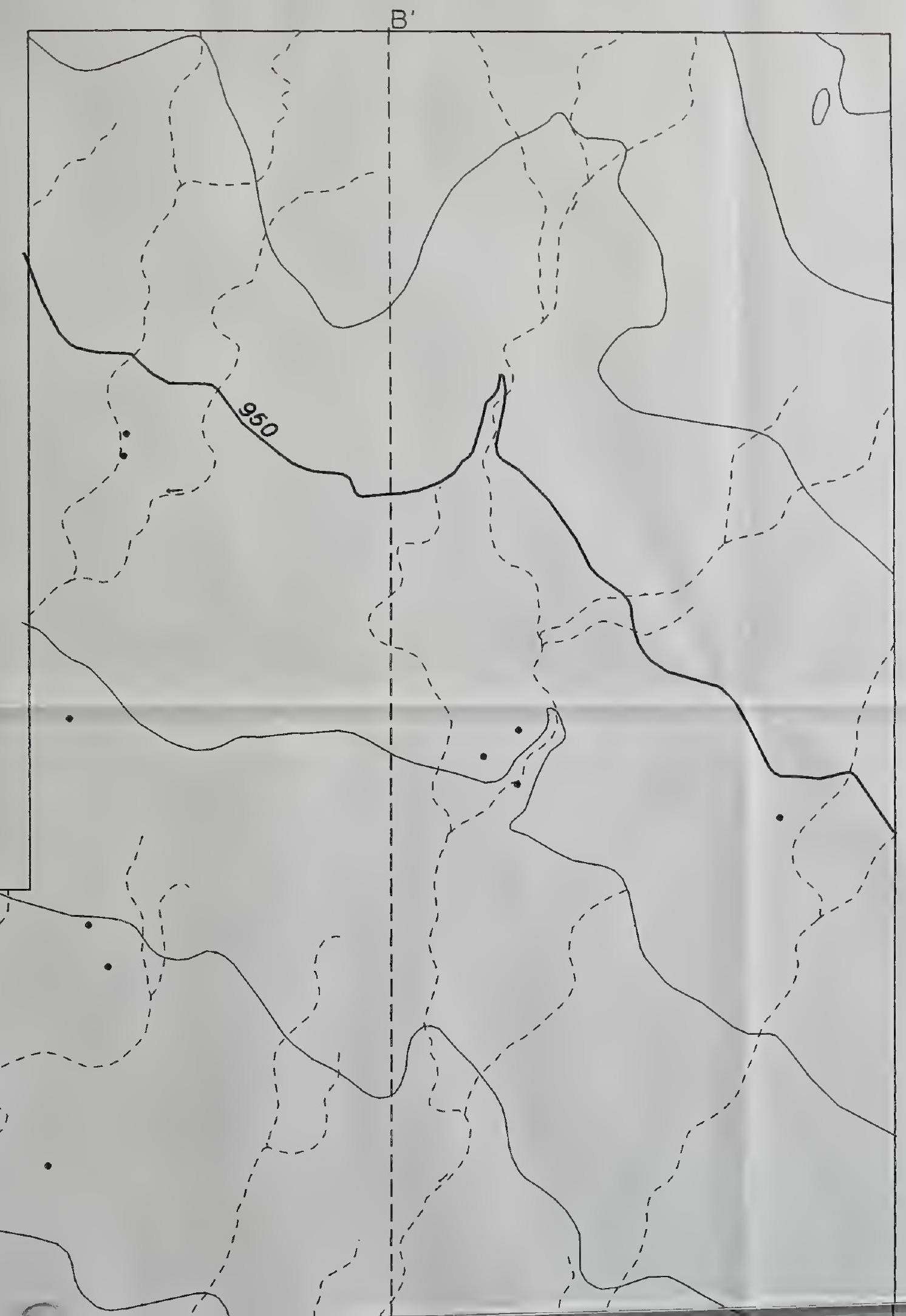





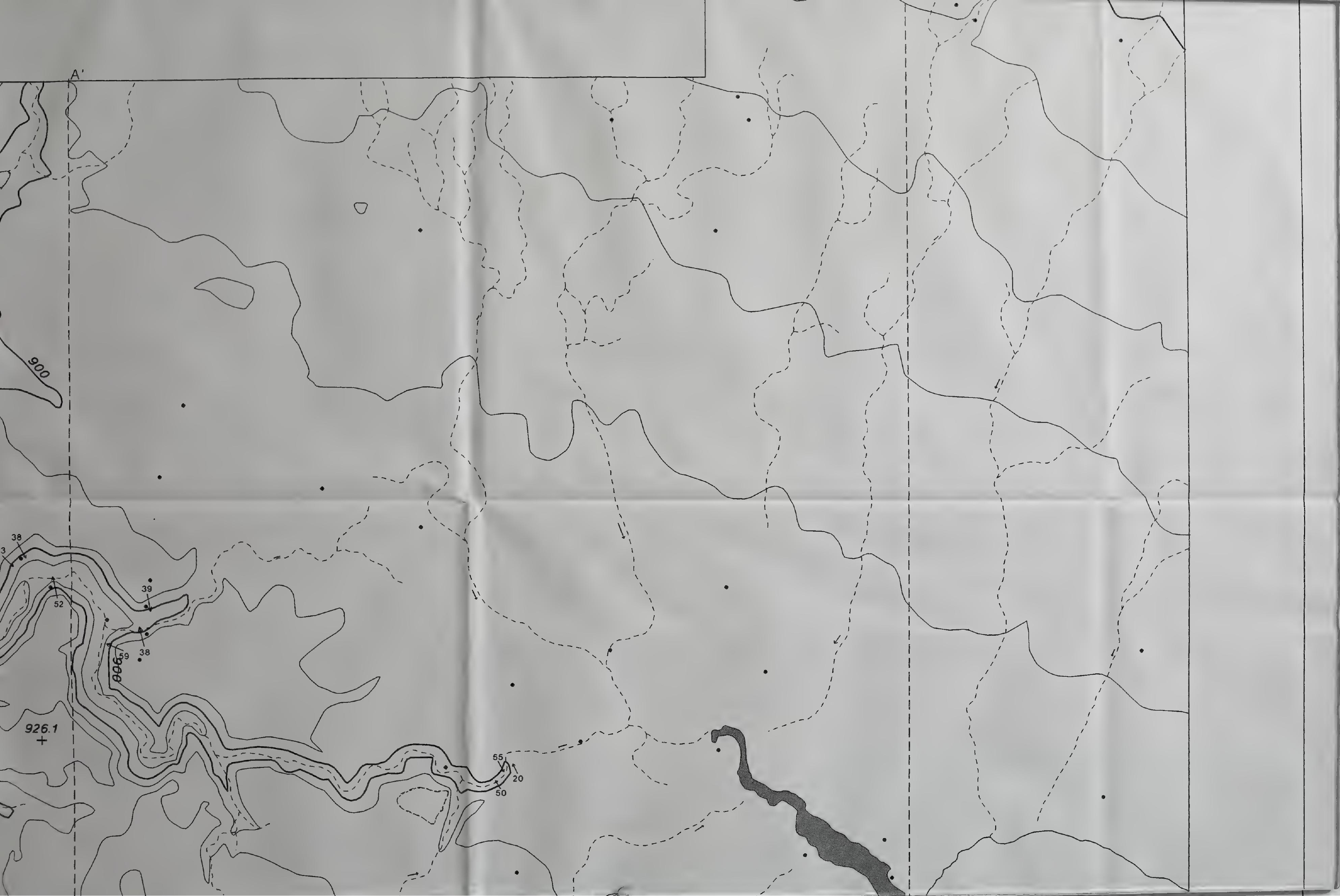




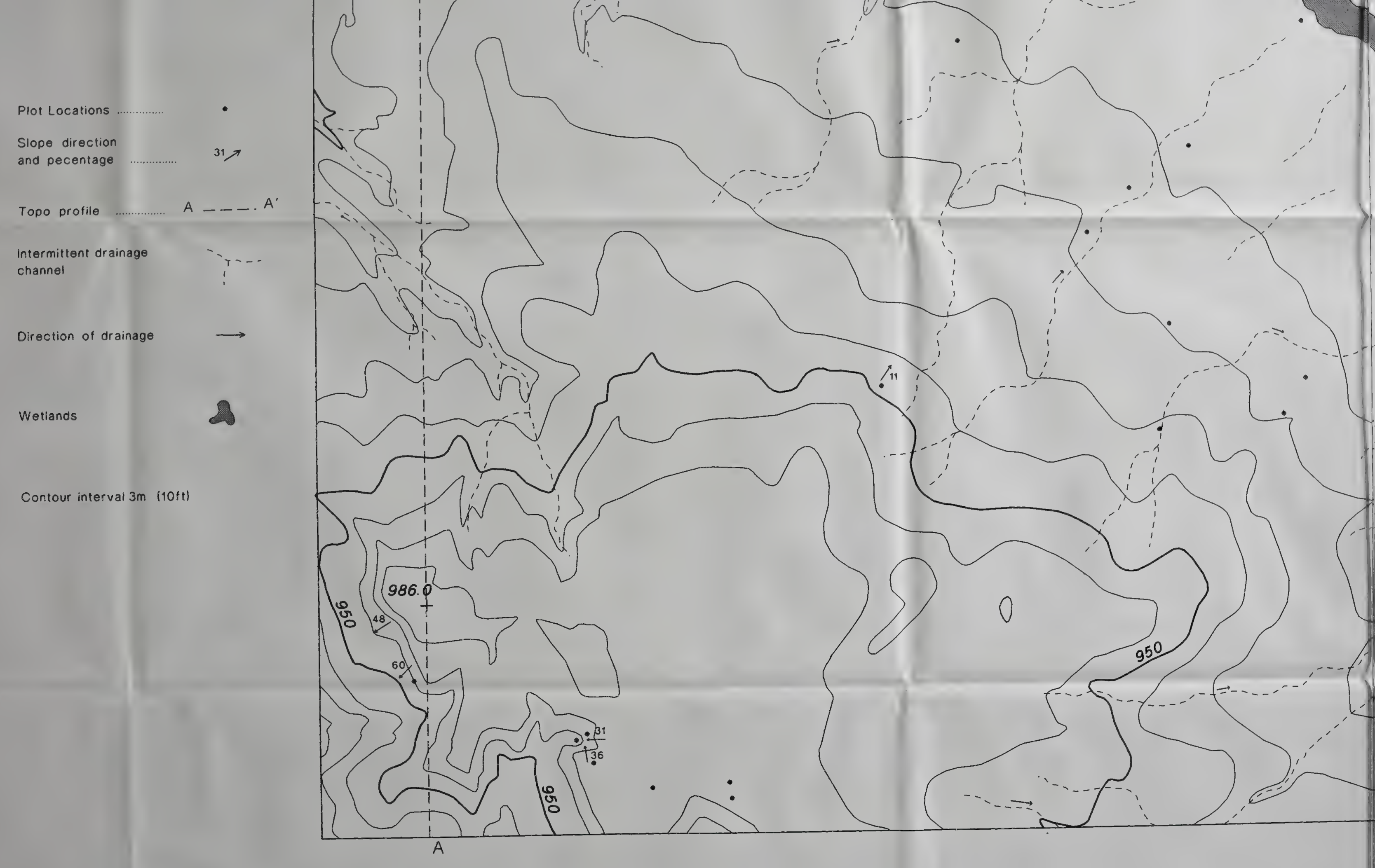




\section{HAND HILLS ECOLOGICAL RESERVE ECOLOGICAL LAND CLASSIFICATION \\ SCALE $1: 10 \quad 000$}

\section{LANDFORMS}

Moraine over bedrock (MR)

1 - morainal veneer on level to undulating bedrock (MR1)

- drainage channels in

overlying bedrock (MR3)

\section{Moraine (M)}

4 - level to undulating morainal veneers and blankets (M1)

- drainage channels on morainal blankets and veneers (M2)

7 - rolling ablation

Glaciolacustrine (GL)

8 . low relief, slightly hummocky glaciolacustrine plain (GL1)

9 - remnant beach ridges $(G L 2)$

Glaciofluvial (GF)

10 - level, inclined and slightly undulating veneers

and blankets (GF1)

11 - inclined veneers lalong coulee slopes) (GF2)

12 - shalow usually well-defined drainage channels IGF3

13 - rounded sand hills (GF4)

14 - kame |GF5|

Rough Broken (RB)

15 - escarpment slopes (RB1)

16 - coulee slopes (RB2)
17 - slump feature (RB3)
18 - coulee bottom (RB4)

Lacustrine (L)

Lacustrine (L)
19 - lacustrine (L1)

Fluvial [F]

20 - drainage channel (F1)

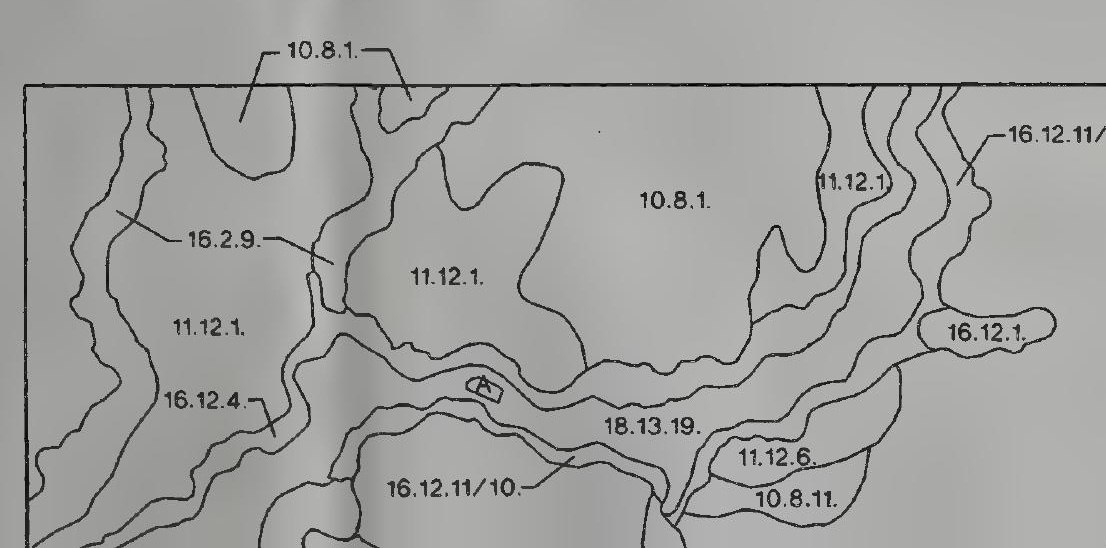

Example of Map Symbol Code

Landform

10.1.5 Vegetation Communities

L Soil Subgroup

If more than one type is present

$x / y-y$ is a smaller proportion of the polygon than $x$

$x / / y$ - $y$ is a much smaller proportion of the polygon than $x$
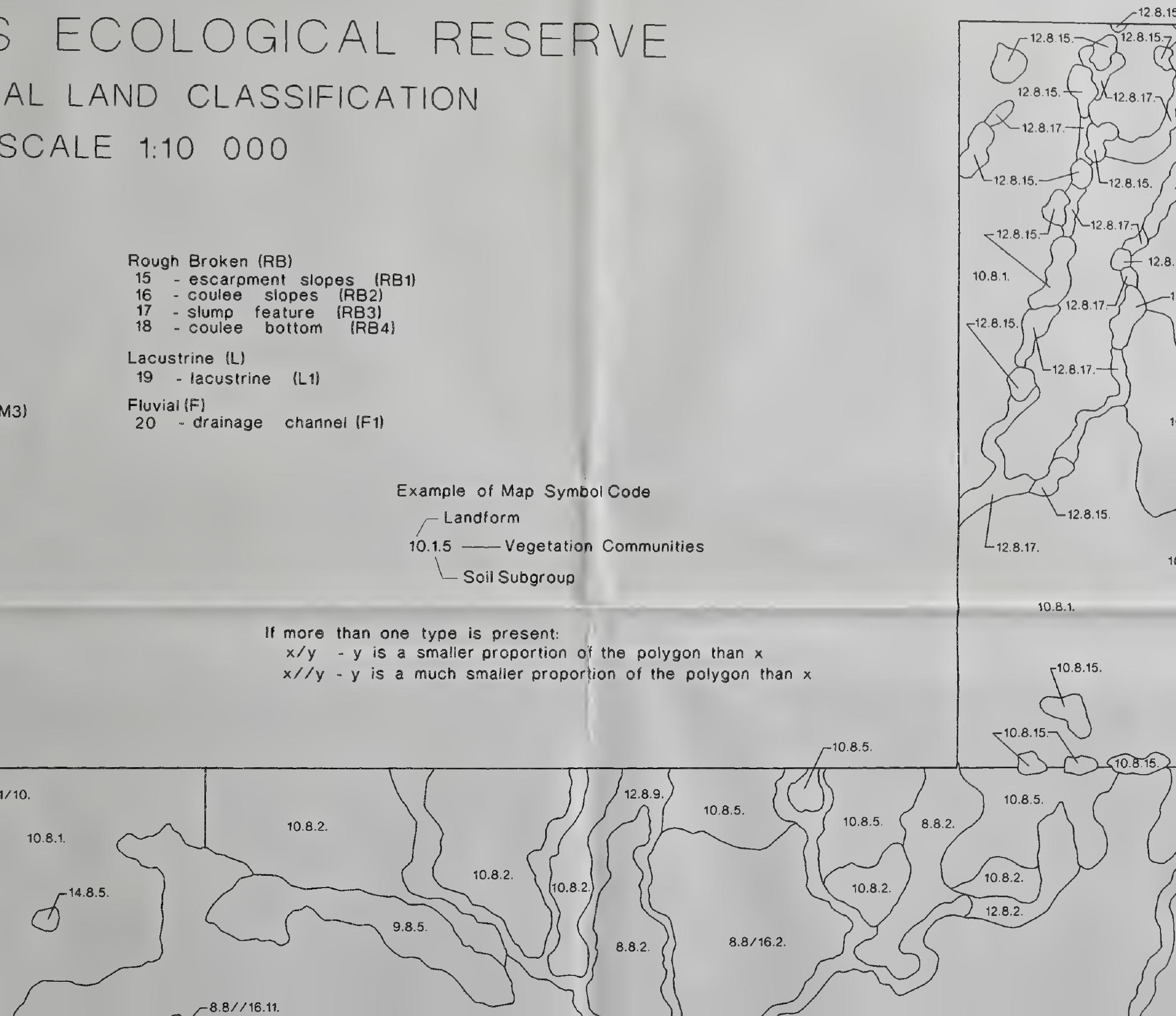


\section{RESERVE}

\section{TION}

\section{Example of Map Symbol Code}

Landform

10.1.5 - Vegetation Communities

\section{Soil Subgroup}

\section{e type is present}

amaller proportion of the polygon than $x$

much smaller proportion of the polygon than $x$

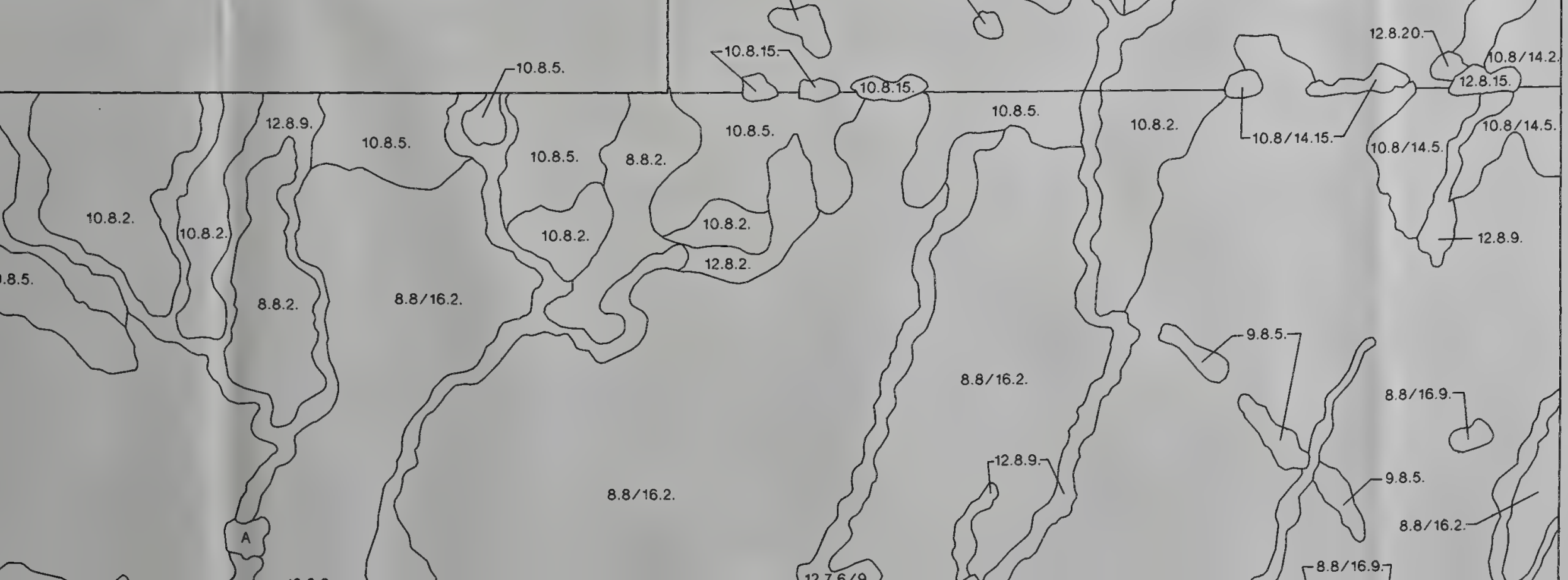




Solonetzic

\section{VEGETATION COMMUNITIES}

\section{Fescue Grassland}

1. Rough Fescue

Mixed Grassland

2 - Rough Fescue-Western

Porcupine Grass

Rough Fescue-Green

Needle Grass-Forbs

4 - Rough Fescue-June Grass-Juniper-Forbs

5 - Western Porcupine Grass.

Rough Fescue-Forbs

- June Grass-Sedge-Sage. Selaginelia

7 - Needle and Thread Grass. Sedge-Selaginella

8 - Gumweed-BluegrassFoxtail Barley

Shrubbery

9 - Buckbrush-Rough Fescue

10 . Rose-Rough Fescue-Forb

11 - Silverberry-Rough Fescue.

Hooker's Oat Grass

12 - Salix/Saskatoon-Rough

Fescue/Bluegrass

13 - Buffaloberry-Rough Fescue

\section{Woodlands}

14 - Aspen-Buckbrush-Forb-

\section{Wheat Grass}

15 - Aspen-Awnless Brome

16 - Poplar-Buckbrush-Wheat Grass

Meadows

17 - Mixed Grass-Forb

18 - Rough Hair Grass-Sedge-Forb

\section{Wetlands}

19 - Bluegrass-Rough Hair Grass. Cinquefoil

20 - Sedge-Rough Hair Grass

21 - Sedge-Wire Rush

W - Water

A - Anthropogenic

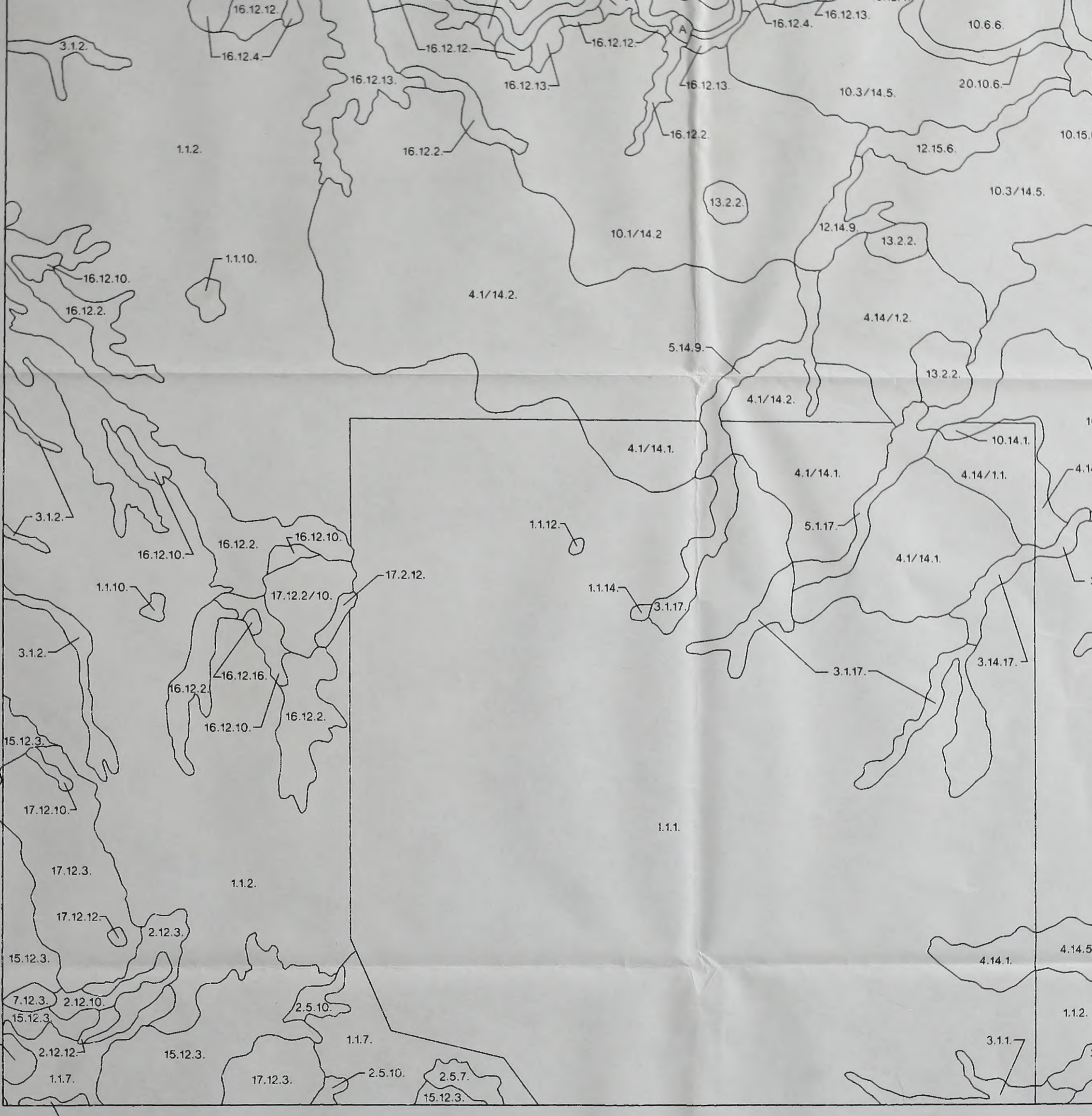

15.12.3.

15.12.3. 

National Library of Canada
Bibliothèque nationale du Canada

3 3286513461208 